Historic, Archive Document

Do not assume content reflects current scientific knowledge, policies, or practices. 



\section{RÓZSA UJDONSÁGOK}

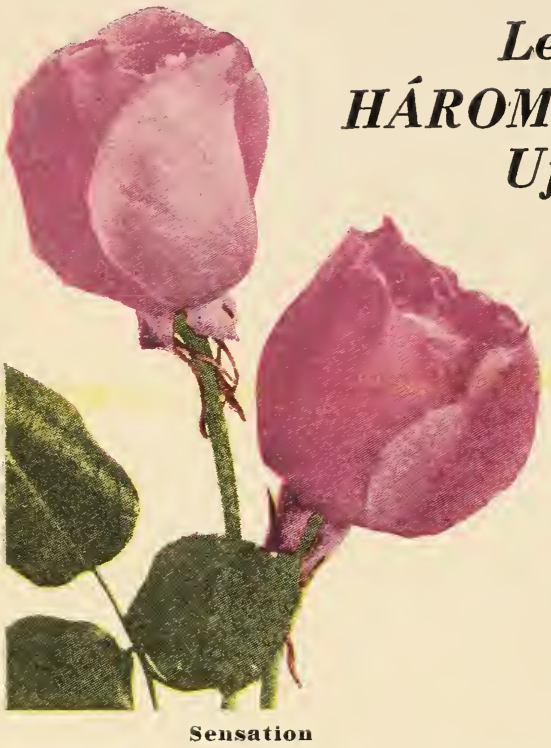

SENSATION. Ezen gyönyörü rózsa-ujdonság a legnagyobb ês a legszebb az összes folyton nyilo tearózsák közt. Az 1922. évi rózsakiállitáson Párisban az elsö aranyérmet nyerte meg. A bimbók, mint látható a képen, gyönyörù hosszu alakuak, melyek bámulatos nagyságra kinyilnak, virága szine fényló vörös, levelei mély zöldek és nagyok, amelyek egész hideg öszig az ágait diszitik, növése dus, egész juniustól hideg öszig szakadatlanul virágzik. Illata felülmulhatatlan, házi kertekböl nêlkülözhetetlen. 1 darab \$2.00.

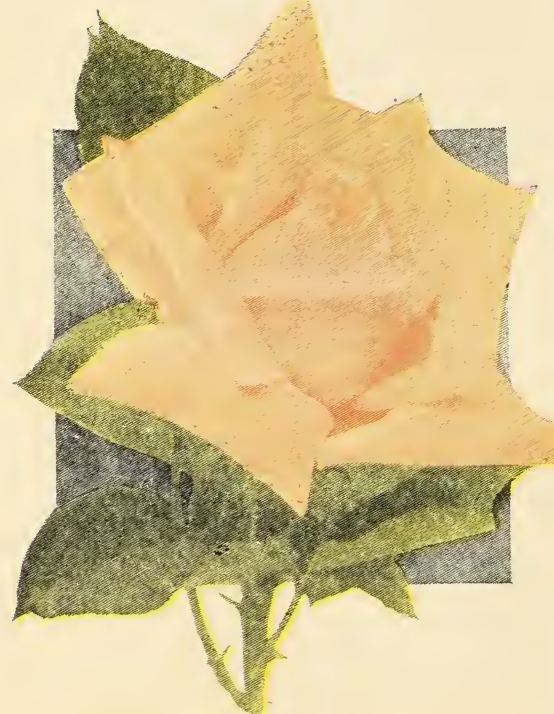

Gold Mine

\section{GOLD MINE}

Ezen uj faj folyton nyiló aranysárga tearózsának már a neve is nagyon megnyerö, de a virágai meg igazán bámulatosak. E rózsa-ujdonságot még csak két éve, hogy a közönségnek bemutatták és már is oly nagyon kedvelt, hogy minden diszesebb rózsakertben látható. Szine bimbókorában, melyek hosszuak és g: y ö n y ö r ü aranysárgák, kinyiló korában pedig a közepe naranes bronz szinné változik, levelei fénylö zöldek és nagyon diszesek, vi rága it hosszu szárakon hozza, dus növö és kitünö illatu, egész hideg öszig szakadatlanul virágzik. Rózsakertekböl nélkülözhetetlen. 1 darab \$2.00.

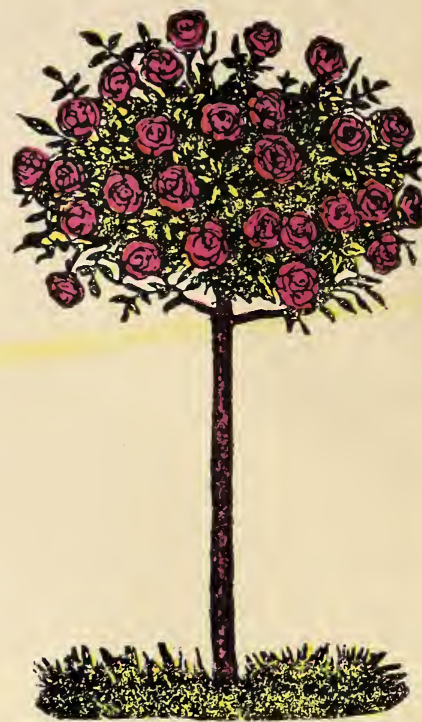

Magastörzsii Rózsák

AMERICA. A legnagyobb és a legszebb, folyton nyiló tearózsa. Ezen rózsa-ujdonság színe ényló rózsaszin, a bímbók hosszuak és hegyesek, amelyek kifejlodnek a legremekebb és rózsaszinnek, mivelhogy rendkivú lyek a legkitünöbb illatuak, nagyon erös növök és teljesen télállók. 1 darab \$2.00. 


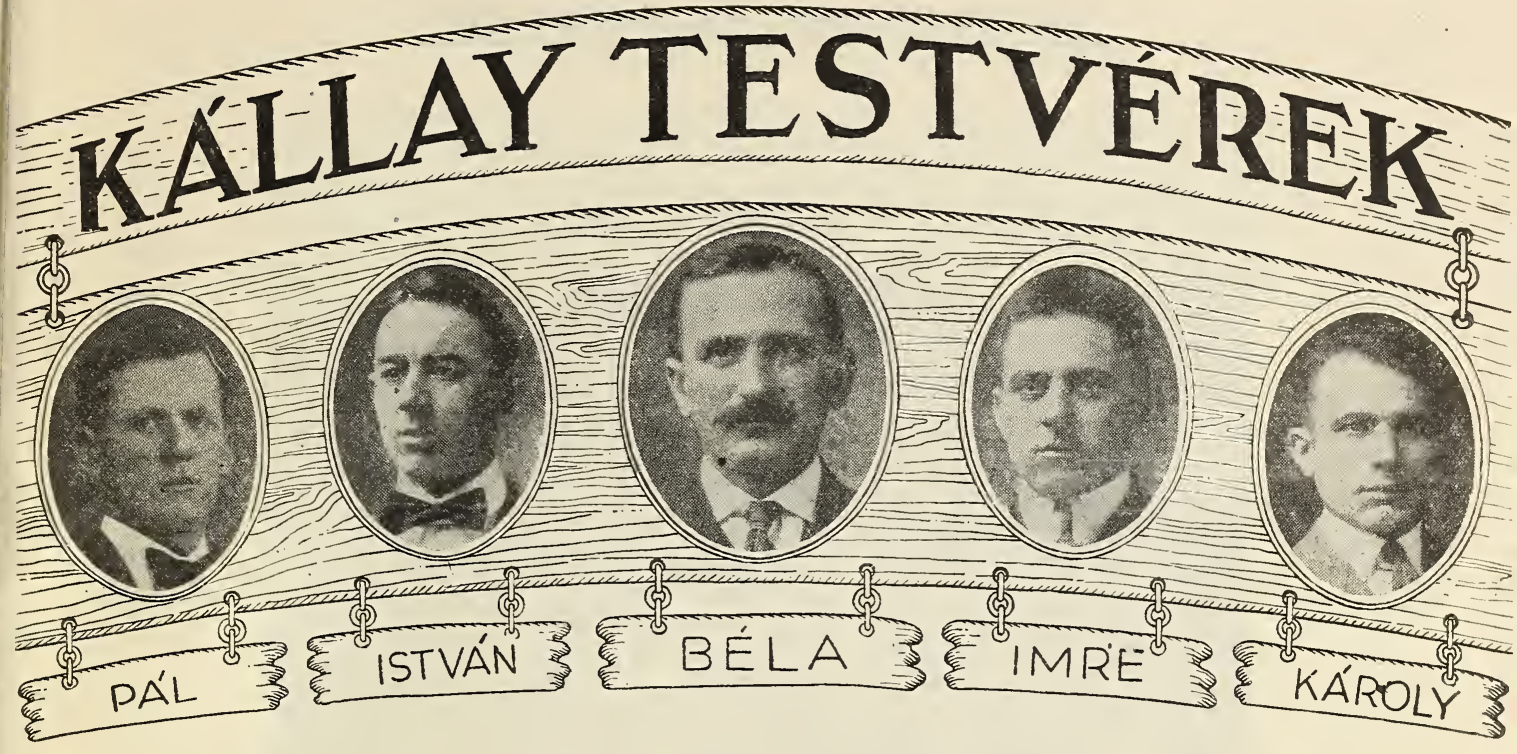

KÁLLAY TESTVÉREK R. T. MAGKERESKEDÉSÉNEK ÉS FAISKOLATELEPÉNEK

\section{NAGY KÉPES ĀRJEGYZÉKE AZ 1927-IK ÉVRE}

Konyhakerti,
gazdasági
és

virágmagvak kereskedése

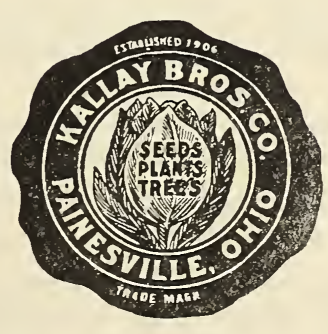

one
KALLAY
BROS.
COMPANY
Lake County
Painesville, Ohio

Gyümölcsfák, rózsafák, fenyőfák, diszfák, diszbokrok 


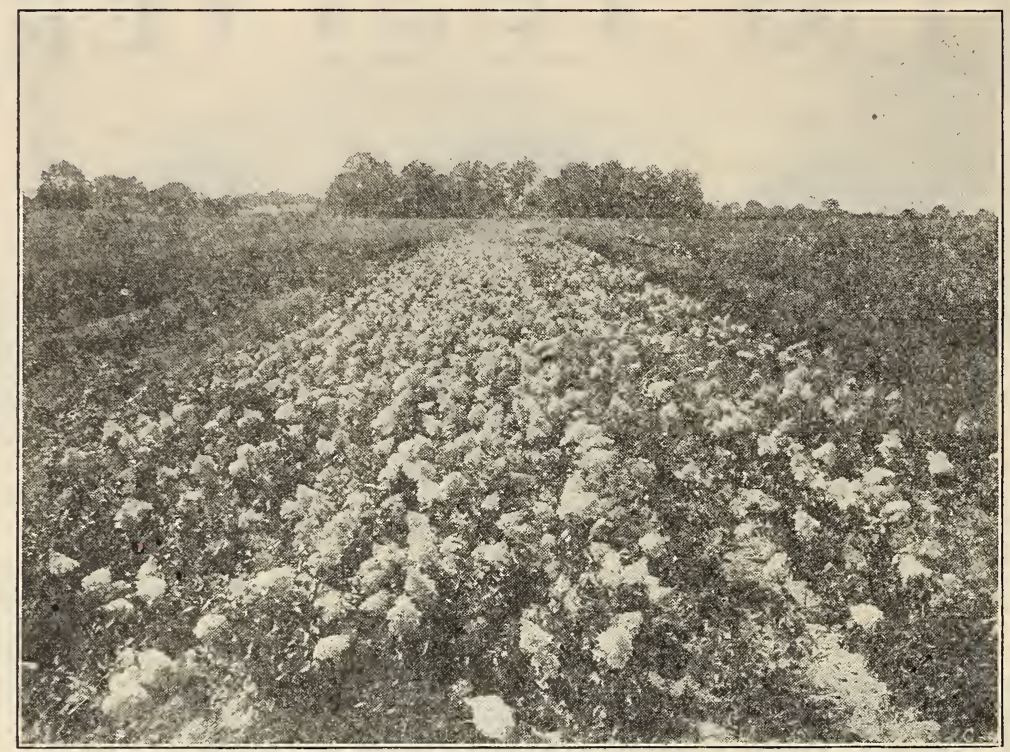

Telepünk egy részlete-Hydrangea-Hortenzia virágzásban.

\section{Igen Tisztelt Vevöinkhez!}

Ezuttal ismételten van szerencsénk magkereskedésünk és faiskolatelepünk immár 21. évi árjegyzékét az igen tisztelt amerikai magyar gazdálkodó és kertészkedő közönség kezeihez juttatni azon tiszteletteljes kérésünk kapcsán, sziveskedjenek azt figyelemmel átnézni és becses megrendeléseikkel cégünket a jövőben is a legnagyobb mértékben megtisztelni.

Az év leforgása alkalmával kedves kötelességünknek tartjuk, köszönetet mondani igen tisztelt vevőinknek a multban minden oldalról megnyilvánult szives pártfogásáért és elismeréséért,, melynek folytán elérhettük üzemünk nagyobb arányu fejlesztését ugy a magkereskedési, mint a faiskolai téren.

Midőn tehát arra kérjük az igen tisztelt vevőinket, hogy a jövőben is szerencséltessenek meg bennünket ezen önzetlen magyaros támogatásukkal - nekünk is, mint eddig, ugy a jövőben is - szorgos törekvésünk lesz az igen tisztelt vevőinknek a legnagyobb foku csiraképes, fajtiszta magyar gazdasági, konyhakerti és virágmagvakat, továbbá kifogástalan nemesitett gyümölcsfákat, rózsafákat s más kerti cikkeket szállitani.

A mag megrendelések beérkezése után azonnal - gyümölcsfa és más növényren. delések akkor, mikor az időjárás alkalmas a rra — intéztetnek el.

Bátorkodunk még megjegyezni, hogy jelen árjegyzékünk kibocsájtásával az összes elöbbeni kiadott árjegyzékeinkben adott árak érvényessége megszünt.

Az ujév alkalmával tehát sikerekben gazdag, eredményteljes munkálkodást kivánva és ugy magkereskedésüink, mint faiskolatelepünk részére nagybecsü megrendeléseiket kérve, vagyunk

kitünő tis ztelettel

KÁLLAY TESTVÉREK R. T. magkereskedése és faiskolatelepe.

Kelt Painesville, O., 1927. évi január hóban. 
HOGYAN TEGYE MEG A RENDELÉSÉT. Kérjük, használja azon megrendelö ivet, mely árjegyzékünk elején található. Igen szépen kérjük t. vevőinket, feltüntetni a megrendelő papiron, vajjon a megrendelt cikkek milyen módon legyenek küldve, ellenkező esetben saját magunk legbiztosabb és legolcsóbb szállitási módját fogjuk igénybe venni. Továbbá kérjük, hogy a t. megrendelő nevét, várost, utca és házszámot vagy egyéb cimet tisztán és olvashatóan kiirni sziveskedjék, mivel az elhibázása folytán sok kellemetlenség történik.

MIKOR TEGYE MEG A RENDELÉSÉT. Mihelyt az árjegyzék kezébe jut, tessék az összes rendelését azonnal összeállitani és azt azonnal hozzánk beküldeni. Mag rendelését azonnal fogjuk küldeni, fa, rózsa és más egyéb bokrok megrendelését mi itten összeállitjuk és mihelyt az idö arra alkalmas, március 15-ike után azonnal küldjük. Ily esetben mindennel szolgálhatunk, ami az árjegyzékünkben fel van tüntetve, de későbbi megrendeléseknél elöfordul, hogy egyes fajok már mind el vannak adva. Szobavirág megrendelése csak április elseje után lesz küldve, mikor arra az idő alkalmas lesz

MILY KÉSŌN IS KÜLDHET MEGRENDELÉST. Egész május utỏljáig küld. het be fa megrendelést. Késő ősszel mindenféle diszfa és gyümölcsfákból nagy menynyiség van pincében (Coal Storage) rakva és amennyiben földjeink a Lake Erie mentén vannak, tavasz két-három héttel is késöbb van és mikor délibb vidékeken már minden kilevelesült, nálunk még mindig levél nélkül vannak.

A MI JÓTÁLLÁSUNK. Az összes szállitásról jótállunk, hogy elsőrendü állapotban jusson a rendelö kezébe. A csomagok megérkezése után tessék azonnal átnézni és ha valami hiányzik, vagy tévesen van küldve, azt tessék azonnal velünk tudatni és mi készséggel kiegyenlitjük.

Jótállásunk folytonos növésre nem terjed ki, ne feledjük el, hogy fa, cserje vagy bármely növény, mind élő lény, épp ugy, mint a tehén, ló vagy ember, lélegzenek, isznak ès táplálkoznak, tehát ki vannak téve mindenféle ragályos betegségnek és veszély. nek, áraink oly mérsékeltek és jutányosak, hogy lehetetlen növésröl felelösséget vállal. ni akkor, mikor a szállitmány elsőrendü állapotban jut a megrendelö kezébe.

\section{SZÁLLITẢSI SZABÁLYOK}

1. Postán bérmentve (ingyen) küldünk az Egyesült Államok bármely részébe minden megrendelést. Kivételt képeznek azonban azok a magvak és magmennyiségek, ahol az árak elött az "Expressen" szó áll jelen árjegyzékünkben.

2. Postán bérmentve (ingyen) küldünk továbbá minden kisebb sulyu szobavirág, virághagyma, virüggyökér, rózsa-bokor, szőlő és más csemete megrendelést. Ezeknél éppen ugy, mint a fentieknél, kivételt képeznek azon cikkek és mennyiségek, amelyek előtt az "Expressen" szó fel van tüntetve az árak előtt árjegyzékünkben.

3. Expressen vagy teheráruként (freight) szállitunk minden olyan megrendelést - a megrendelö önköltségén - amely mảgvak mennyisége elött az "Expressen" szó árjegyzékünkben fel van tüntetve. - Ebbe a csoportba tartoznak nagyobb mennyiségü gazdasági-, fü- és takarmány-magvak, burgonya, stb.

4. Expressen vagy teheráruként (freight) eszközlünk továbbá minden nagyobb gyümölcsfa, rózsafa, szőlöcsemete, stb. nehezebb sulyu megrendeléseket. Ezek elött is az "Expressen" szó mindenhol fel van tüntetve az árjegyzékünkben s ugy mint a 3. pontban, mindig a megrendelö fizeti a szállitás költségeit.

5. Canadába kivételesen csak magmegrendeléseket küldünk és azt is csak postán. Expressen nagyobb mag, gyümölcsfa és más csemete megrendeléseket - a jelen viszonyok miatt — nem küldhetünk. 


\section{FIZETÉSI FELTÉTELEK}

1. Megrendelésekkel együtt igen szépen kérjük az összeg elözetes beküldését, mert megrendelések pontosan csak ez esetben eszközölhetők.

2. Utánvételi (C. O. D.) megrendeléseket csak olyanformán teljesitünk, ha a megrendelt cikkek összegének egy része a rendeléssel mellékelve van.

3. Pénzt legbiztosabb "Postal Money Order"-on, "Express Money Order"-on, vagy ajánlott levélben (Registered) beküldeni. Kisebb rendeléseknél postabélyegeket is elfogadunk.

4. Canadai megrendelőinket kérjük, pénzt csak money order, vagy pénz alakjában küldjenek, megrendelések esetén. Canadai postabélyegeket nem fogadunk el. Ugyszintén kérjük a canadai megrendelőinket, hogy minden egyes megrendeléssel 15 centet a szállitásra extrán beküldeni sziveskedjenek.

5. Áraink a legjutányosabban lettek megszabva és igy árengedményekkel csak nagyobb mennyiségek vételénél szolgálhatunk.

6. Jelen árjegyzékünk kibocsájtásával valamennyi előbbi árjegyzékeinkben adott árak érvényessége megszünt.

\section{Jótállásunk magvaink valódiságáról és csiraképességéről}

Annak dacára, hogy a legnagyobb sulyt arra fektetjük, hogy magvaink a nevének és minőségének megfeleljenek és ha valami módon mégis nem annak bizonyulnak, aminek állitva vannak, mi a legnagyobb készséggel azon hibát kiegyenlitjük, akár ujabb magvakat küldünk, akár a pénzét visszaküldjük. Fentemlitett felelősségünk semmiesetre sem terjedhet ki nagyobb összegre, mint amibe azon mag került, mely nem felelt meg annak, aminek szállitva lett.

\section{IGEN TISZTELT VEVÓINKHEZ}

Ezidei árjegyzékünkben felajánlunk több maggyüjteményt jutányos áron és csak azt kivánjuk megjegyezni, hogy rendelés esetén ne tessék névszerint mindent külön leirni, csak a gyüjtemény számát tessék megnevezni.

\section{KONYHAKERTI MAGGYÜJTEMÉNYEK}

1. Szám ára $50 \mathrm{c}$
Ritka alkalom azon vevöknek, kiknek kicsi városi kerthelyiségük van. 1. szám. 10 adag válogatott fajok postán házhoz szállitva $50 \mathrm{c}$.
1 adag $\mathrm{Bab}$, zöldhüvelyü, szálkamentes

1 adąg Borsó, folytontermő

1 adag Cukordinnye, nagy Kantalup

1 adag Hagyma, kerek vérvörös

1 adag Petrezselyem, magyar félhosszu 10c 1 adag Paprika, aranysárga 10c 1 adag Paradicsom, legkorábbi Spark-féle... 10c

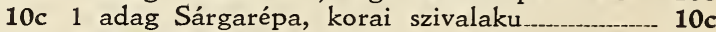
10c 1 adag Céklarépa, tüzgolyó 10c 1 adag Retek, korai hógömb
2. Szám ára $\$ 1.00$
2. szám. 20 adag válogatott konyhakerti magvak postán házhoz szállitva $\$ 1.00$.
1 adag $\mathrm{Bab}$, aranyhüvelyü, szálkamentes

1 adag Cukorborsó, amerikai csoda.

1 adag Dinnye, korai dijnyerö_

1 adag Dinnye, görög, Watson-féle óriás

1 adag Hagyma, Danversi óriás

1 adag Káposzta, Mauthner-féle

1 adag Kalarábé, kék bécsi

1 adag Kárfiol, fehér rózsa

1 adag Petrezselyem, édes magyar

1 adag Paprika, édes óriás 10c 1 adag Paradicsom, juniusi, piros 10c 1 adag Sárgarépa, Mauthner-féle 10c 1 adag Céklarépa, korai vérvörös 10c 1 adag Retek, hónapos korai, rózsapiros

10c 1 adag Saláta, májusi király

10c 1 adag Tök, sütő, arany Hubbard

10c 1 adag Tengeri, asztali, korai cukor

10c 1 adag Ugorka, hosszu zöld

10c 1 adag Zeller, gumós, prágai óriás

10c 1 adag Zeller, amerikai szár 


\section{Megbizható Csiraképes Konyhakerti Magvak}

\section{BOKORBAB}

\section{(GYALOGPASZULY.)}

TENYÉSZTÉSE: Ültessük el a magot már akkor, mikor a fagy teljesen eltávozott a földből. Hideg időben a vetőmag csirázás közben elrothad. A bokorbab fajokat ültethetjük egy és fél láb távolságra fekvő bokrokba, egy-egy bokorba 5-6 szem magot téve, vagy pedig vethetjük a magot szórva két láb távolságra fekvő egymástóli sorokba is. Szabad, verőfényes és jól megmunkált, könnyü talajt kiván.

\section{a) Sárga hüvelyü vagy viasz fajok}

\section{WARDWELL-FÉLE ARANYVAJ BOKORBAB.}

Ezen fajta a legtökéletesebb viaszbabnak ismertetett el, mert rendkivül porhanyó és zsenge, soha sem szálkás és nagyon finom izü. Szép aranysárga hüvelyeit bámulatos nagy mennyiségben hozza, amelyek rendkivül vastagok és husosak s teljesen szálkamentesek, ha már érni kezdenek is. Legkitünőbb tulajdonsága e fajnak a hüvelyeknek vajzsenge ize és rendkivüli korasága. Adg. 15c; 1 font $45 c$; 2 font 80c. Expressen 10 font $\$ 3.00$.

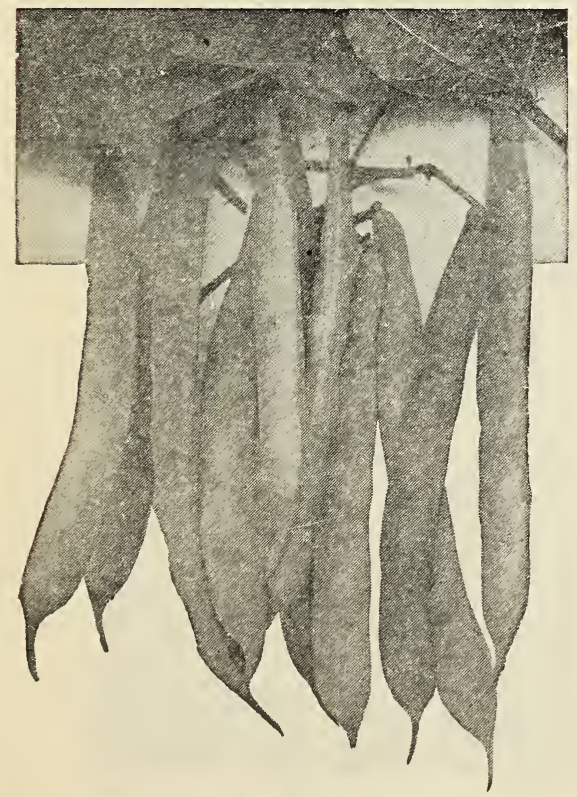

Wardwell-féle Aranyvaj Bokorbab

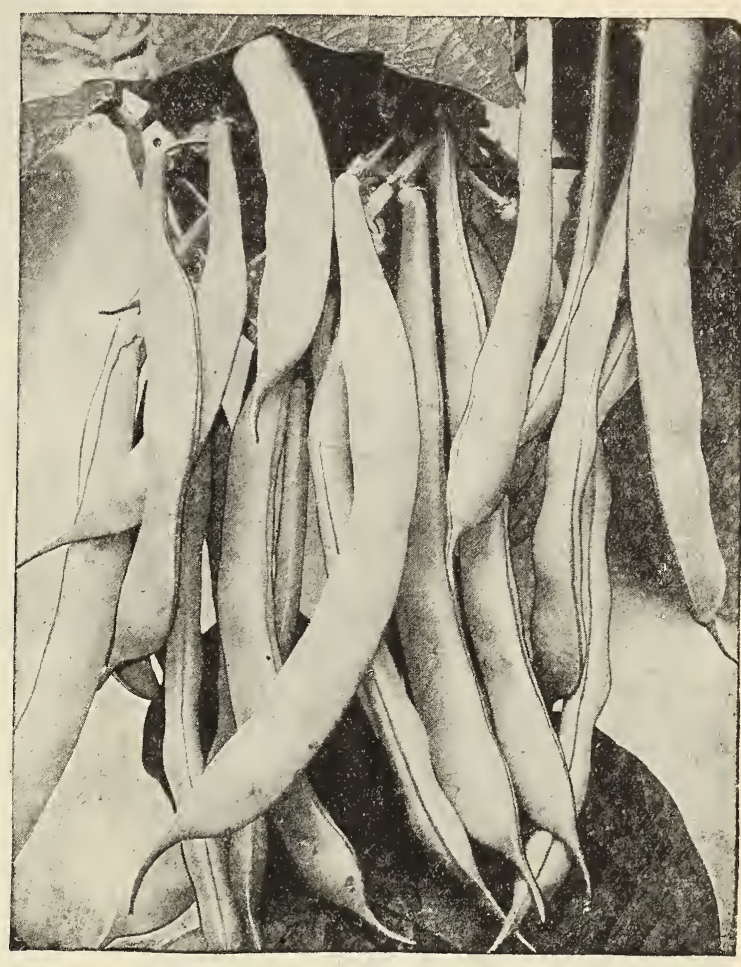

Korai Arany Viasz-Bokor Bab

KORAI ARANYVIASZ. Legkorábbi és a legjobb babfaj házi kertek részére, magánhasználatra, piaci termelésre bőtermősége folytán tulhaladja az összes bokor babfajokat. Hüvelyei vastag és széles, törékeny és teljes szálkamentes. Aranysárga hüvelyei nagy sokaságban jelennek meg a növényeken és zsengén, legjobban birja a messzebbi szállitást és a sárga hüvelyü fajok között egyike a legjobb és a legizletesebb faj asztali használatra és nagyban keresett piaci fajta, magja barna pettyes fehér. Adg. 10c; 1 font 40c; 2 font 75c. Expressen 10 font $\$ 3$.

JAVITOTT ROZSDAMENTES ARANY VIASZ BOKORBAB. A legujabb a babok közt. Hüvelyei általánosan 5-6 inch hosszu, egyenesen növő, vastag husu, lapos, széles, aranysárga szinü és teljesen szálkamentes, mig csak a szemek ki nem fejlödnek. Szára a földtől magasra emelkedik, egy és féltől két láb magasra. A hüvelyeit szinte fent a tetején hozza és azáltal hüvelyei rozsdamentes és nem rothad el. Ugy házi használatra, mint nagybani piaci termelésre elsőrendü. Adg. 15c; 1 font $45 c ; 2$ font 80c. Expressen 10 font $\$ 3.00$.

DETROITI ARANYVIASZ BOKORBAB. Legjobb aranyhüvelyü szálkamentes bokorbab, a növése $1 \frac{1 / 2}{2}$ láb magas, kemény, sárga. A késői tavaszi fagyokat is kibirja. Bötermősége felülmulhatatlan és teljes szálkamentes. Hüvelyei széles laposak, élénk sárga szinüek, ezért a zöldségtermelők nagyon kedvelik. Mag vetésétől számitva 40 nap alatt hüvelyei 4-5 hüvelknyi hosszura fejlödnek és lehet használni fözésre. Adg. 10c; 1 font 40c; 2 font 75c: Expressen 10 font $\$ 3.00$. 


\section{BOKORBAB (Folytatás.) a) SÁRGA HÜVELYÜEK.}

FEHÉR VESE VIASZ. Igen korai és nagyon bötermő. Hüvelyei 6 inch hoszszuak, lapos és zsenge viasz fehér szinüek, a legkitünöb' tulajdonsága ezen fajnak az, hogy téli kannázásnál a hüvelyek nem vesztik el a szép viasz fehér szinüket és sok ideig zsengén megmaradnak a szárakon. Házi kertek részére különösen ajánlható faj, piaci termelésre pedig valóságos arany. bánya, mivel hogy a szállitást kitünően birja. Adg. 10c; 1 font $40 c$; 2 font $75 c$. Expressen 10 font $\$ 3.00$.

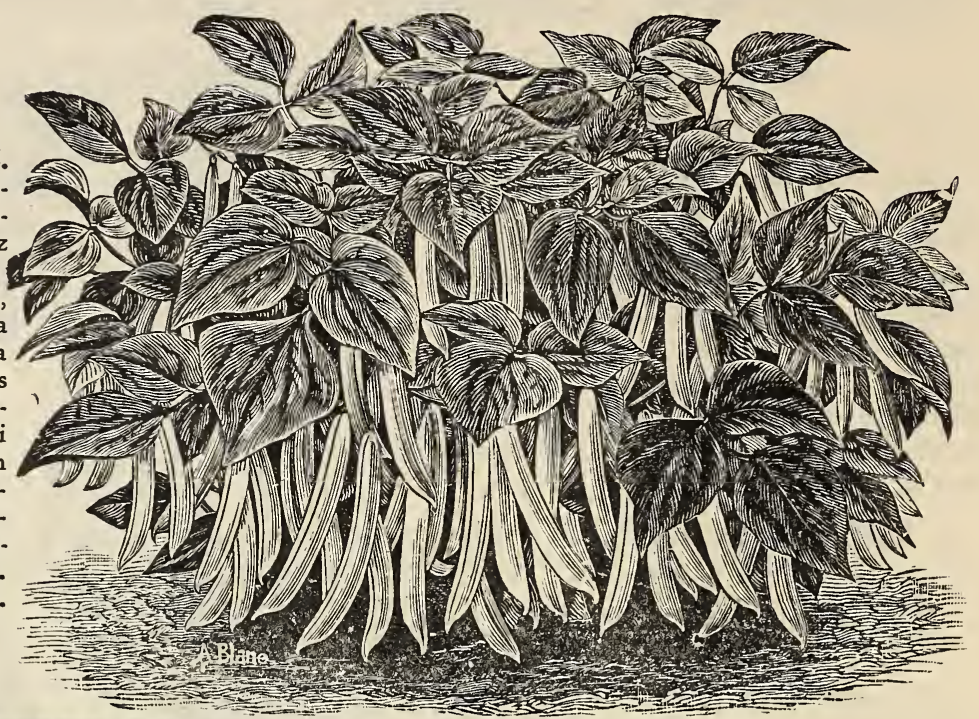

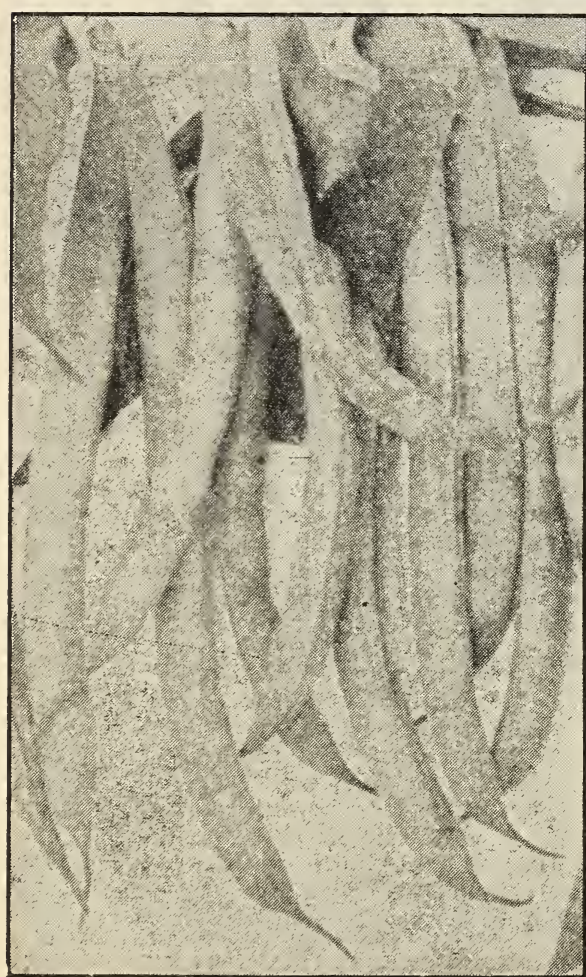

Aranyhüvelyü Bokorbab

ARANYHÜVELYU் SZÁLKAMENTES. Ezen kitünő sárga hüvelyü bokorbabról lehet irni, hogy a korai fehér szemü arany viasz. Egyike a legkorábbi a viasz fajbabok között. Szárai nagyon erősen növők és borzasztó bőtermök, a hüvelyei aranysárgák, szépsége és minősége nagyban hasonlit a nagyban ismert Korai Arany Viasz-hoz csak az a
Fehér Vese Viasz-Bokorbab

különbség, hogy ennek a magja tiszta fehér. Családi kertek részére megbecsülhetetlen faj bö hozománya által. Nagy bőtermőségével piacra való termelésre nagyon ajánlatos. Egy-egy növény 20-25 hüvelyt is hajt, oly bötermö. Adg. 10c; 1 font 40 cent; 2 font 70c. Expressen 10 font $\$ 3.00$.

JAVITOTT NÉMET FEKETE VIASZ. Roppant erősen növő és igen bőtermő törpe viasz bab. faj, a hüvelyei nagyon hosszuak és majdnem gömbölyüek és teljesen tömve vannak apró fekete bab szemekkel. Nagyon zsenge és kitünő izü, korán érik és a rozsdának nincs ugy alávetve, mint a régebbi viasz babfajok. Adg. 10c; 1 font 40c; 2 font 70c. Expressen 10 font $\$ 3.00$.

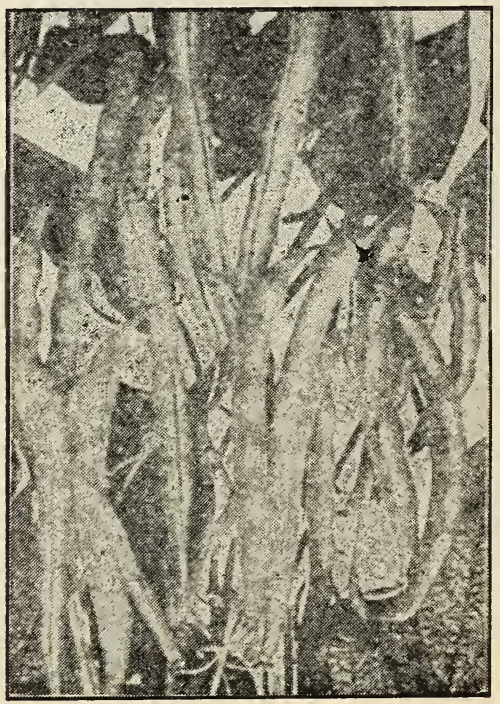

Német Fekete Viasz 
BOKORBAB (Folytatás.) b) ZÖLD HÜVELYÜEK.

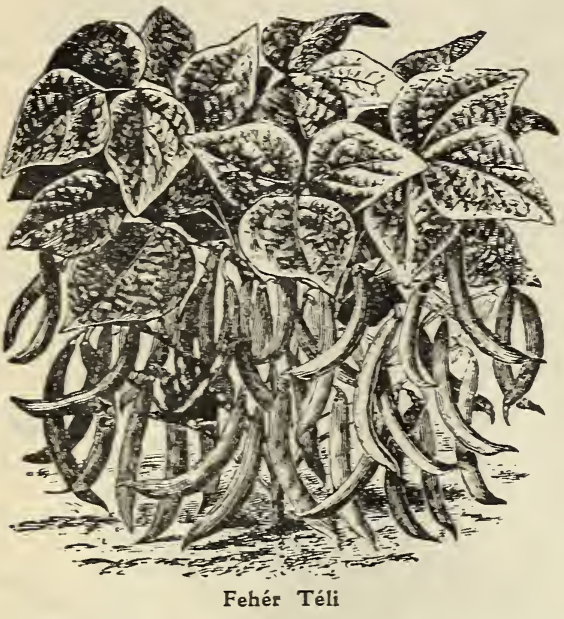

FEHÉR TÉLI. Az általánosan ismert téli használatra termelt kitünő izü fehér bab. A hüvelyek nagy csomókban fejlödnek a növényszárakon és ennélfogva nagyon bő hozamu. Nagy, fehér magvai kitünö téli eledelt nyujtanak. Adag 10c; 1 font $35 c ; 2$ font 60c. Expressen 10 font $\$ 2.50$.

FEKETE VALENTINE. Rendkivüli gazdagon növő, korai faj nagy hosszu husos hüvelyekkel, a melyek 6 inch hosszuak vékony és majdnem gömbölyü és teljes egyenes. Hüvelyeik sötét zöldek, a bab szemek pedig teljes feketék. Tökéletesen rozsdamentes. Ugy zölden elkészitett hüvelyei, mint kifejlett fekete magjai kellemes eledelt adnak. Adg. $10 c ; 1$ font $40 c ; 2$ font 70c. Expressen: 10 font $\$ 3.00$.

TARKA TÉLI. Nagyon bőtermő piaci babfaj. Nagy kifejlett magvai vörössel tarkázottak, ugy. szintén a hüvelyei is cirmosak. Ugy kifejtve zsenge állapotban, mint télen száraz fózésre rendkivül finom és izletes. Adg. 10c; 1 font $40 c ; 2$ font $70 c$. Expressen 10 font $\$ 3.00$.

KORAI HOSSZU HATHETES. Óriási hosszu zöld hüvelyü bokorbab faj. Nagyon korai és bőter. mő. Hüvelyei 5-6 inch hosszuak, lapos és vilá. gos zöld szinü. Házi használatra a legkitünőbb korai szedése miatt. Magja középnagy világos sárga sötét barna szemekkel. Adg. 10c; 1 font $45 c ; 2$ font 80 c. Expressen 10 font $\$ 3.00$.

ZÖLD SZÁLKAMENTES. A legkorábbi és a legjobb vastag husu és a zöld hüvelyü az összes babfajok között. Attól a perctől fogva, amikor a földbe teszi a magot, számithatjuk dijnyerőnek és aki ezen faj zöld hüvelyü babot egyszer kipróbálja, az többé más fajt soha nem használ. A hüvelyek 7 inch hosszuak és nagyon kövér, teljes szálkamentes, nagyon törékeny és zsenge, a hüvelyek nagyon uniformisan fejlődnek ki, ugy hosszuságra, mint vastagságra, zsengén elkészitve a legremekebb eledelt szolgáltatja. Magja nagy sötétbarna, amely zsengén a hüvelyből kifejtve, szintén izletes. Adg. 10c; 1 font 45c; 2 font 75c. Expressen 10 font $\$ 3.25$.

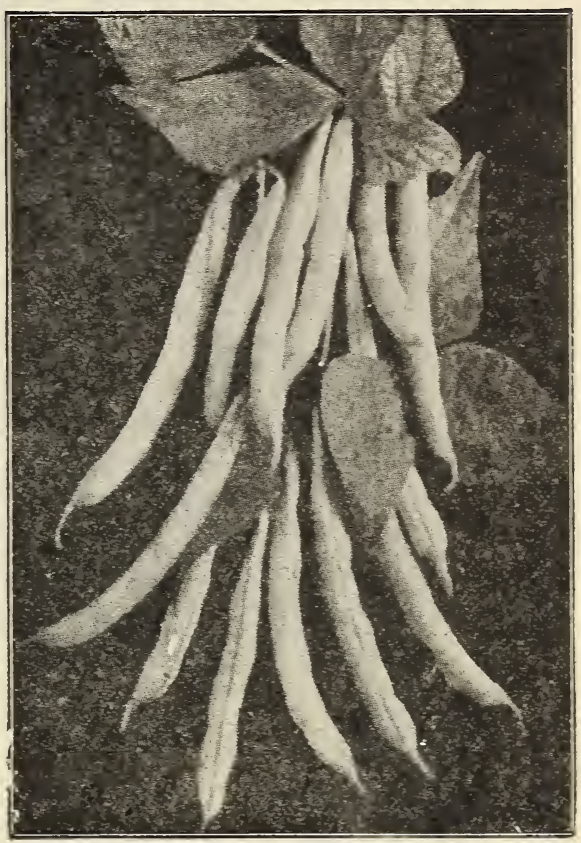

Korai Hathetes

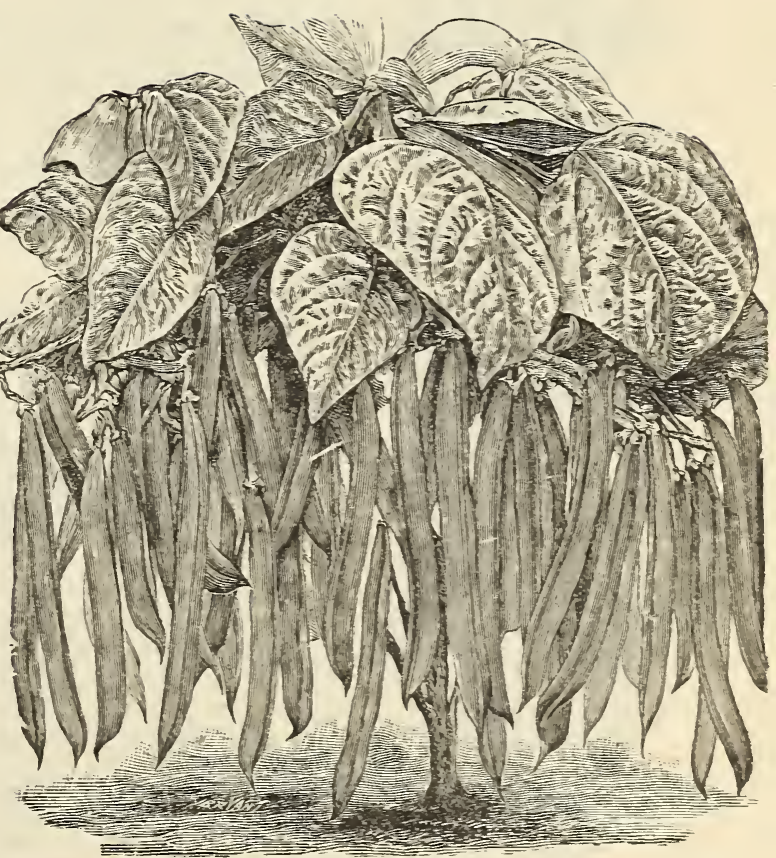

Zöld Szálkamentes-Bokorbab 


\section{KARÓS BAB (Karós paszuly).}

TENYÉSZTÉSE: Május közepe elött, mig a talaj át nem melegült, nem veteményezhető. A mag három-négy láb távolságbani bokorban ültetendö. Egy-egy bokorba 5-6 magot teszünk, amelyekhez idejében hosszu karókat alkalmazunk. Ju niustól fogva egész a fagyok beálltáig folyton terem.

KORAI FÜRTÖS VIASZ. Legfinomabb és legbőtermőbb sárga hüvelyü karós bab. A különbség ez és a Csemege viasz bab közt csak az, hogy ezek a babszemek kissé laposabbak és rövidebbek, a hüvelyek $6 \mathrm{col}$ hosszuak és $3 / 4 \mathrm{col}$ szélesek. A hüvelyeket nagy fürtökben hozza, 5-6 hüvely minden fürtön, nagyon könnyen és szaporán lehet szedni. Aranysárga hüvelyei ugy zsengén elkészitve, mint nagy fehér magjai télire kitünő eledelt nyujtanak, késő őszig, a fagy beálltáig folyton termi a pompás hüvelyeit. Adag $15 \mathrm{c}, 1$ font $45 \mathrm{c}, 2$ font 80 c. Expressen $10 \mathrm{ft} . \$ 3.50$

MAUTHNER-FÉLE FEHÉR ÓRIÁS. Igen széles, hosszu, husos, kitünő izü, zöld hüvelyü fajbab. Teljesen szálkamentes hüvelyei fürtösen jelennek meg a szárakon, amely nagyon bőtermövé teszi. Vaj izü, kifejlett nagy, fehér magvai ugy zsengén, mint télen szárazon kitünö eledelt

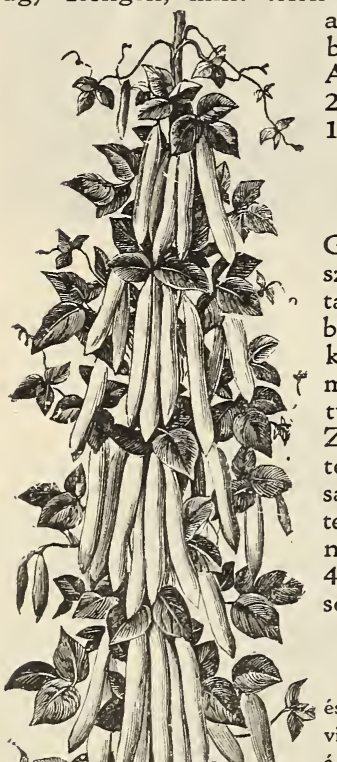
adnak. $\mathrm{Az}$ őszi fagyok beálltáig folyton terem. Adag 10c; 1 font 40c; 2 font 75c. Expressen 10 font $\$ 3.25$.

TARKA MEZEI. Gömbölyü alaku rózsaszinü és vörös sávokkal tarkázott fehér magu bab, amely ugy zsengén kifejtve és elkészitve, mint télire használva, kitünő izü eledelt nyujt. Zöld husos hüvelyei szin tén vörössel pettyesek és sávozottak. Kitünő faj tengeri szárakra felfuttat ni. Adag 10c; 1 font 40c; 2 font 75c. Expressen 10 font $\$ 3.25$.

CSEMEGE VIASZ. A legizletesebb és legzsengébb aranysárga hüvelyü karos viasz bab. Az összes piaci termelök azt állitják, hogy a legjobb izü és sárga hüvelyü karos babok között. Bötermö. sége felülmulhatatlan, a hüvelyeket mind fürtökben hozza és a növény különösen erőteljesen fejlödik. A hüvelyek $7.8 \mathrm{col}$ hosszuak és a görbe nyerges hátu hüvelyei nagyon szélesek és amellett igen vastag husuak és teljesen szálkanélküliek. A babszemek középnagyok és sötét barnák, ovális laposak és érett állapotban rendszerint egy kissé ráncosak, minthogy ezen uj viaszbab igen ellenállóképes és edzett, különösen alkalmas egyébként zord vidékre és ha vetve van a korai fajokkal együtt, akkor mire a korai fajok a termést elhagyják, ezen faj akkor kezdi bötermését. Adag 10c, 1 font $40 \mathrm{c}, 2$ font $75 \mathrm{c}$. Expressen 10 font $\$ 3.25$.
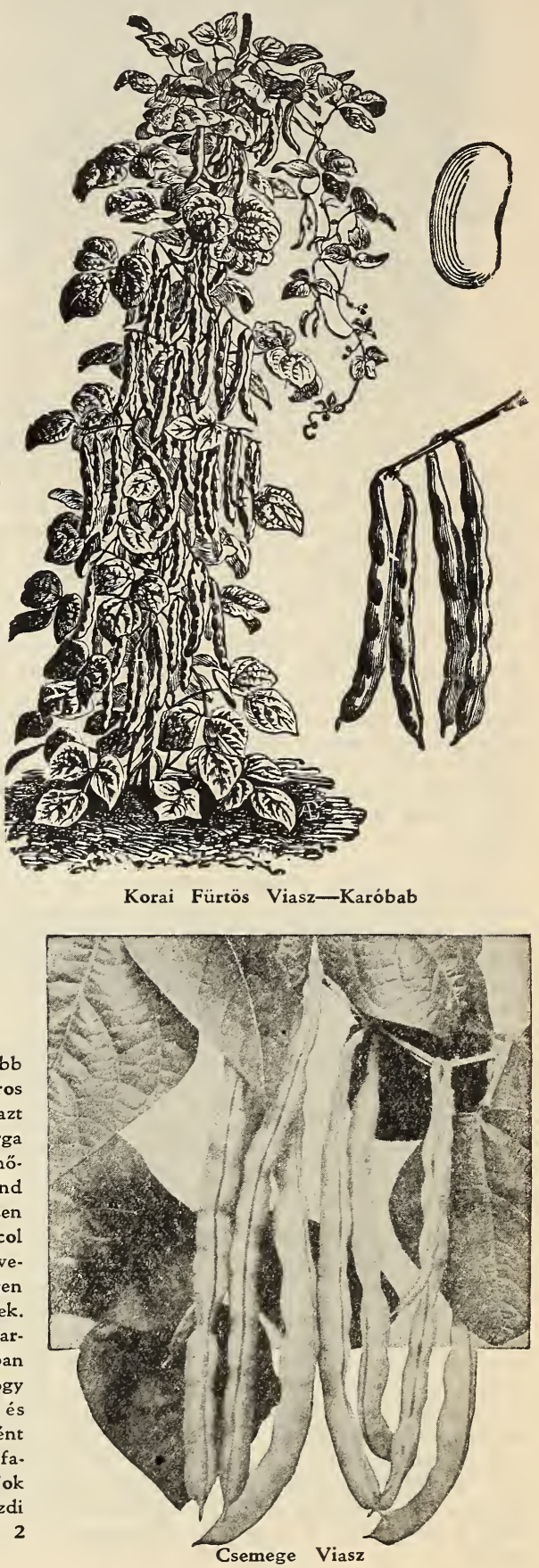


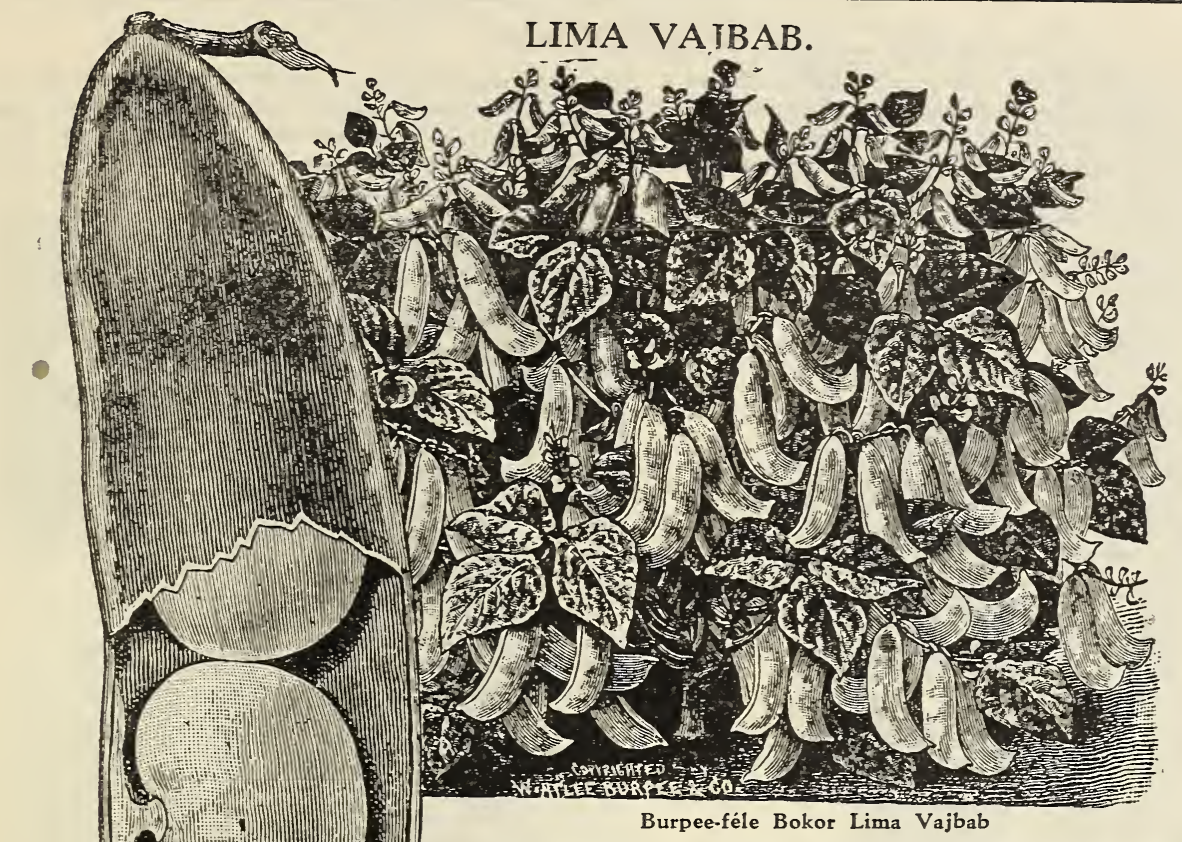

BURPEE-FÉLE BOKOR. Ugy a hüvelyek, mint a szemek óriási nagyok. A hüvelyek között 5-6 inch hosszuak, a növény törpe és nagyon erős növő, a hüvelyeket mind fürtökben hozza és a hüvelyek teljesen tömve vannak kitünő vajizü zsenge babszemekkel. Magja nagysága majdnem akkora, mint egy cent, lapos, nyá. ron kifejtve és télen száritva egyformán a babok legkitünőbbje, zölden kifejtve a piacon nagy ára van, házi kertekből elmaradhatatlan. Adg. 10c; 1 font 50c; 2 font 90c. Expressen 10 font $\$ 3.50$.

KERTEK KIRÁLYA. Ezen babfaj csak éppen olyan, mint a Burpee-féle, izlésére. Hüvelyek nagysága 6-8 col hosszuak és többször 6 babszemet is hoz egy hüvelyben. Csak mig az elöbbeni bokortermő, ez pedig futó és megkövetel 8-10 láb hosszu karokat. Egész a fagy beálltáig folyton hozza a termését. Kifejtett magja zsengén elkészitve finom, omlós vaj izü. Télire száritott magja elkészitve csemege. Adag 10c, 1 font 50c, 2 font 90c. Expressen 10 font $\$ 3.25$.

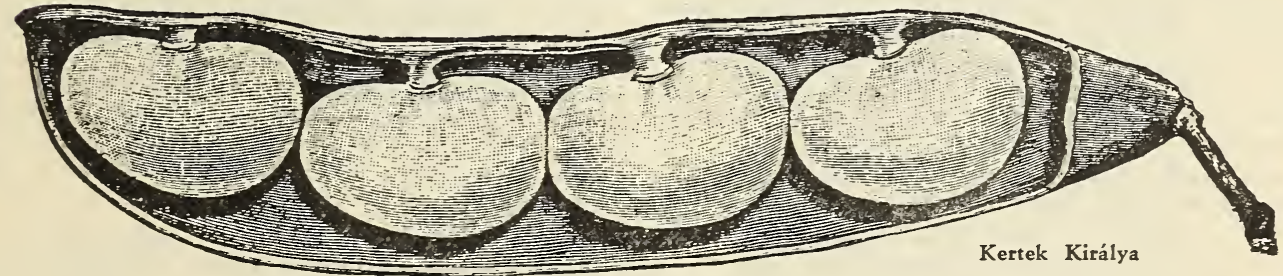

\section{KERTI vagy LÓBAB.}

TENYÉSZTÉSE. Vessük a magot kora tavaszon a földbe, mihelyt csak a földet munkálni lehet. (Ugyanis ez a babfaj eltér a többiektől, hogy nem árt neki a nedves és hideg idő.) Tenyésztése és kezelése egyenlö a közönséges fajokéval.

ANGOL WINDSOR. Nagy széles, fehér hüvelyü és magu lóbab. Fiatal, kifejtett magvaival sós vizben megfőzve, tápláló eledelt adnak. Adg. 10c; 1font $45 \mathrm{c} ; 2$ font $70 \mathrm{c}$.

\section{DISZBAB.}

NAGY VöRöS VIRÁGU. Remek, nagy élénk tüzvörös virágu futó (kuszó) babfaj. Sokan ked. velik virágjáért, de kifejlett, nagy magva egyszersmint kitünő eledelt ad. Adg. 10c; 1 font $40 \mathrm{c} ; 2$ font $75 c$. 


\section{BOKOR-BORSÓK.}

TENYÉSZTÉSE: Kora tavasszal, mihelyt a talaj megmunkálható, a borsó már vethető. Vessük a magot egy láb távolságbani hosszu sorokban. A borsó-félék frissen trágyázott földet - épp ugy, mint a babok - nem kivánnak, mert ez esetben a növényszárak buja növésbe mennek át és hüvelyeket nagyon keveset hoznak. A bokor-borsók szabad, szellős helyen szeretnek. Állandó használatra vessünk folytatólagosan magot minden két hétben és mire az egyik vetésről a termés lefogy, a másik vetés már kész a szedésre.

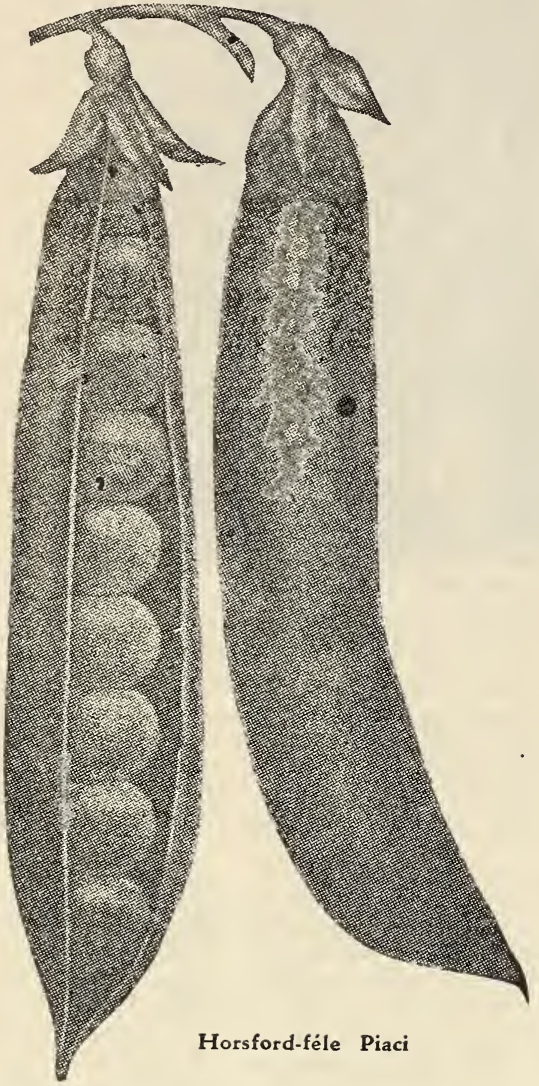

ALASKA. Az eddig termelt borsófajták között a legkorábbi és legbőtermőbb. Nagybecsü piaci áru, ugy, mint a családi kertèk számára, kitünő izletességénél fogva. Márciustól szeptemberig vethető. Hüvelyei szép fejlettek, nagy édes szemekkel. Adag 10c; 1 font 45c; 2 font 75 c. Expressen 10 font $\$ 3.00$.

AMERIKA CSODÁJA. Egy láb magasra növõ, alacsony, bötermő asztali borsó, nagyon finom, édes izü, nagy szemekkel. Családi kertek számára nélkülözhetetlen faj. Korai és késői vetésre egyformán megfelel. Adag 10c; 1 font $45 \mathrm{c} ; 2$ font $75 \mathrm{c}$. Expresszen 10 font $\$ 3.00$.

GRADUS. Közép nagy, márvány alaku szemeket termő korai bokor-borsó. Hüvelyeit nagy sokaságban hozza, amelyek tömve teltek édes izü szemekkel. Adag 10c; 1 font $40 \mathrm{c} ; 2$ font $70 \mathrm{c}$. Expresszen 10 font $\$ 2.75$.

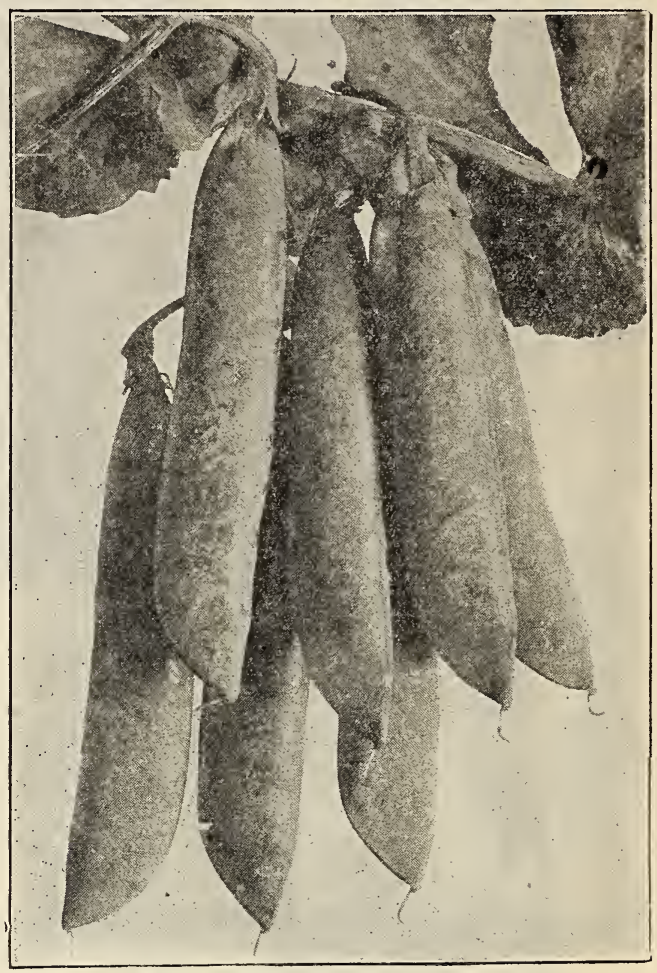

Korai Velöborsó "Márványgolyó"

KORAI VELÓBORSÓ "MÁRVÁNYGOLYÓ". Roppant bőven termő, igen korai, márvány alaku szemeket termő bokorborsó. Hüvelyeit nagy sokaságban hozza, amelyek tömve vannak nagyon édes izü szemekkel. Nagyon ajánlható piaci termelésre és ugyszintén házi kertek részére is megbecsülhetetlen, mivel a háziasszony korán állithat belöle az asztalára. Vessük el a magot, mihelyt a fagy kimegy a földböl és ismételten három-négy külön esetben, 10 napi időközönkint, ugy, hogy mire az egyik terem, a másik már kész a használatra. Adag 15c; 1 font 50c; 2 font 90c. Expresszen 10 font $\$ 3.50$.

HORSFORD-FÉLE PIACI.-_Egyike a legjövedelmezőbb kései market fajoknak. Rendkivül bötermő. Hüvelyei középnagyok, kellemes, édes izü szemekkel. Adag 10c; 1 font 45c; 2 font $75 c$. Expresszen 10 font $\$ 3.00$.

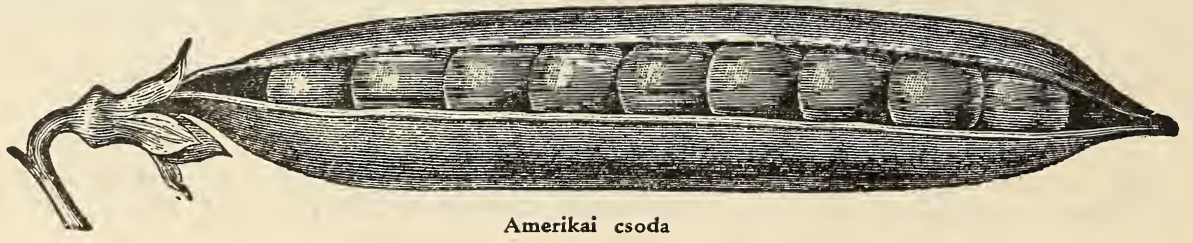




\section{KARÓS-BORSÓK.}

TENYÉSZTÉSE: Egy és fél láb távolságbani hosszu sorokban vetendô a mag, mihelyt a talaj megmunkálható. A mag kikelte után idejében lássuk el a növényeket rőzse-támaszokkal vagy karókkal, a növény-szárak felfuttatására.

FOLYTONTERMÖ. Gazdag és kitünő izü csemege borsó. Hüvelyei középnagyok, édes szemekkel teltek, amelyek érett állapotban sárga szinüek. Családi kertek részére megbecsülhetetlen faj. Adag 10c; 1 font 45c; 2 font 80c. Expresszen 10 font $\$ 3.00$.

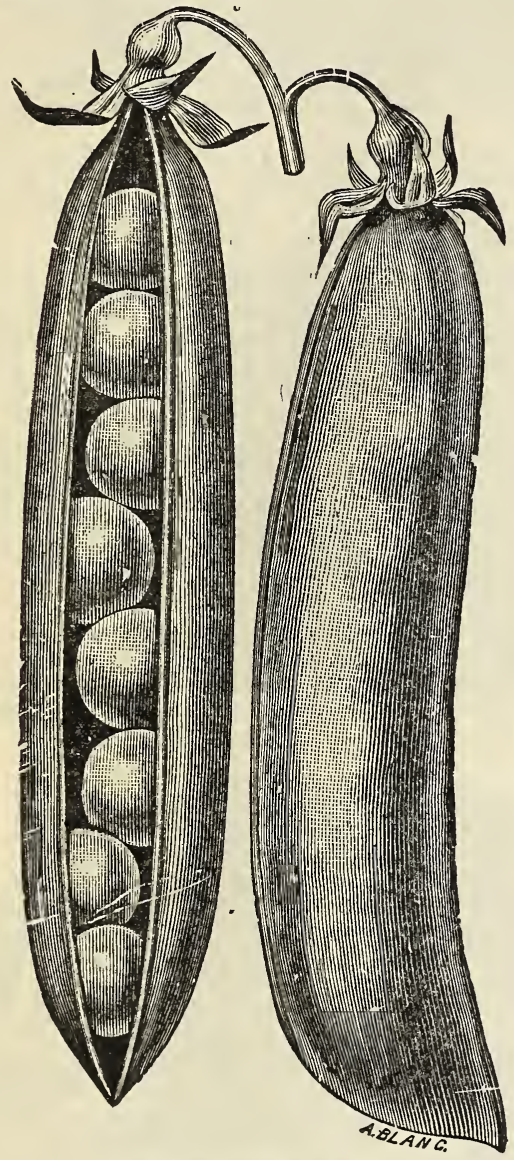

Legkorábbi-Karósborsó

LEGKORÁBBI. A legkorábbi és legbőtermőbb karós-borsók egyike. Hüvelyei telve nagyon édes izü szemekkel. Bö termése folytán ugy házi kertek részére, mint piaci termelésre az első helyet foglalja el. Adag 10c; 1 font 45c; 2 font 80c. Expresszen 10 font $\$ 3.00$.

TELEFON. Háromtól négy láb magasra növő cukorédes szemü, kései faj. A növények tele folyton termő hüvelyekkel. Nagybecsü családi kertek számára, kitünő izletességénél fogva. Hüvelyei szép fejlettek, nagy, édes szemekkel. Adag 10c; 1 font 45c; 2 font 80c. Expresszen 10 font $\$ 3.00$.
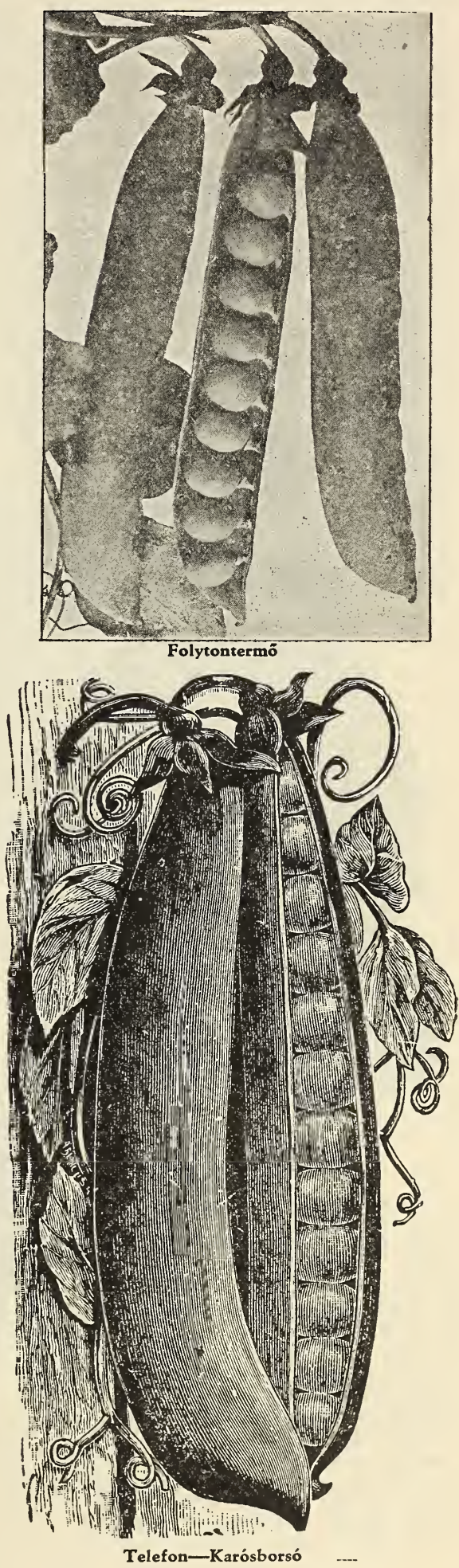


\section{SÁRGA ÉS CUKORDINNYÉK.}

TENYÉSZTÉSE: Trágyával jól összekevert földbe, 4-5 láb távolságnyira fekvő halmokba, vagy fészkekbe ültessük be a magot. Mikor a magvak már kikeltek és a növények megerösödtek, hagyjunk meg csak 4-5 növényt egy halomban. Mihelyt a föinda 4-5 levélhosszat eléri, ajánlatos a harmadik levél fölött visszacsipni, ezzel a müvelettel a termővirágok gyorsabban jönnek és fejlődnek. Esöben vagy harmatban a dinnyében járni nem tanácsos.
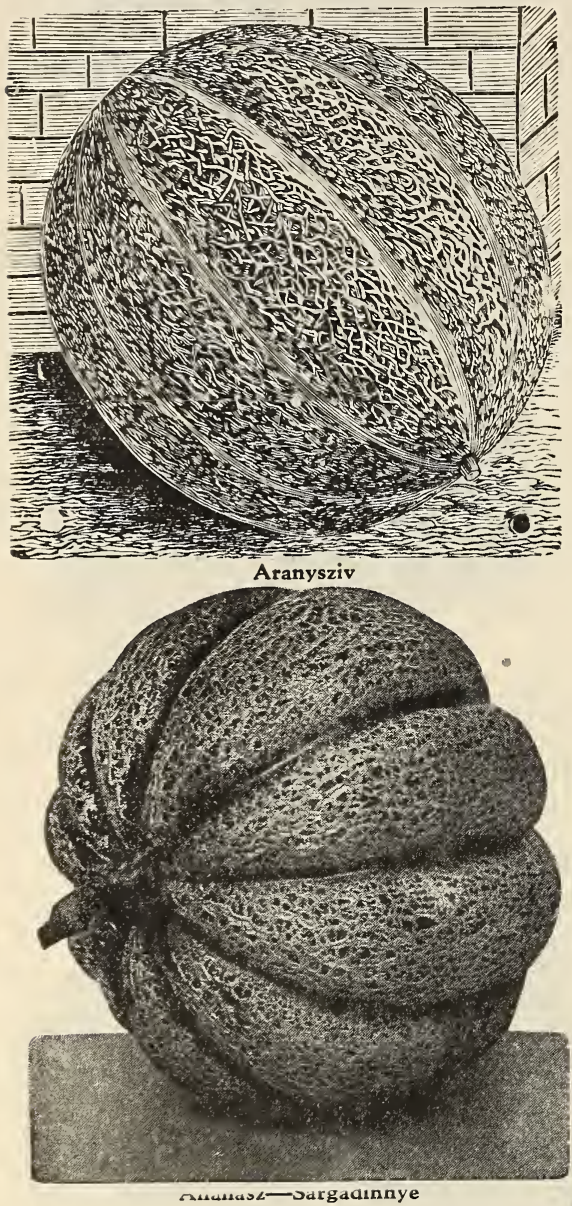

\section{"ARANYHUSU KANTALUP" CUKOR DINNYE,}

A most kulturában levő legszebb és legjobb izü dinnyék egyike. Husa remek aranysárga és egész a héjáig élvezheti. Ize rendkivül édes, olvadó és üditő zamatu. Bőtermősége folytán a dinnyetermelők között nagyon ismeretes és egyes vidékeken ezen faj hetvenöt százalékát képezi a dinnyetermelésnek. Nagybani ter melésre nagyon gazdaságos, mivel már augusztus elején érik és nagyon jó árat fizetnek érte. Adag 10c; ounce (1-16 font) 25c; $1 / 4$ font $60 \mathrm{c} ; 1$ font $\$ 2.25$.
ARANYSZIV. Egyike legjobb a korai sárga dinnyék közt. Rózsaszin és aranysárga husa igen leveses és zamatos, egész héjáig élvezhető, ugy asztali, mint piaci termelésre nagyon ajánlható. Adag $15 \mathrm{c}$; ounce (1-16 font) $30 \mathrm{c} ; 1 / 4$ font $80 \mathrm{c} ; 1$ font $\$ 2.75$.

ANANÁSZ. Recézett, kiválóan finom, olvadós, zöld husu faj. Igen leveses és zamatos. Ha megérik, sokszor a csutkájáról leválik. Adag 10c; ounce (1-16 font) $20 c$; $1 / 4$ font $60 c ; 1$ font $\$ 2.00$.

KORAI DIJNYERó. Kerek és gerezdes alaku cukordinnye faj, világoszöld, vastag, omlós hussal. Nagyon korai és bőtermő. Adag 10c; ounce (1-16 font) $25 \mathrm{c} ; 1 / 4$ font $75 \mathrm{c} ; 1$ font $\$ 2.00$.

SÁRGAHUSU MÉZÉDES. Korai nagy, bordázott cukordinnye faj. Finom izü, világos narancssárga, héjáig élvezhető vastag hussal. Husa igen leveses, omlós és zamatos. Adag 10c; ounce (1-16 font) $25 c ; 1 / 4$ font $75 c ; 1$ font $\$ 2.25$.

MÉZ HARMAT. Nagyon keresett, jó árban a piacokon, majdnem gömbölyü, erős héja van és a szállitást birja bármely távolságra. Mikor érett, a héja teljesen fehér és sima, ize oly édes, mint a méz. Adag 15c; ounce (1-16 font) 30c; $1 / 4$ font $80 \mathrm{c}$; 1 font $\$ 2.75$.

NAGY KANTALUP. Böven termő, nagyon édes izü, omlós husu dinnyefaj. Husának szine remek narancssárga, a mag közelében rózsaszinü. Alakja recézett és gömbölyü. Adag $10 \mathrm{c}$; ounce (1-16 font) $20 \mathrm{c} ; 1 / 4$ font $60 \mathrm{c} ; 1$ font $\$ 2.00$.

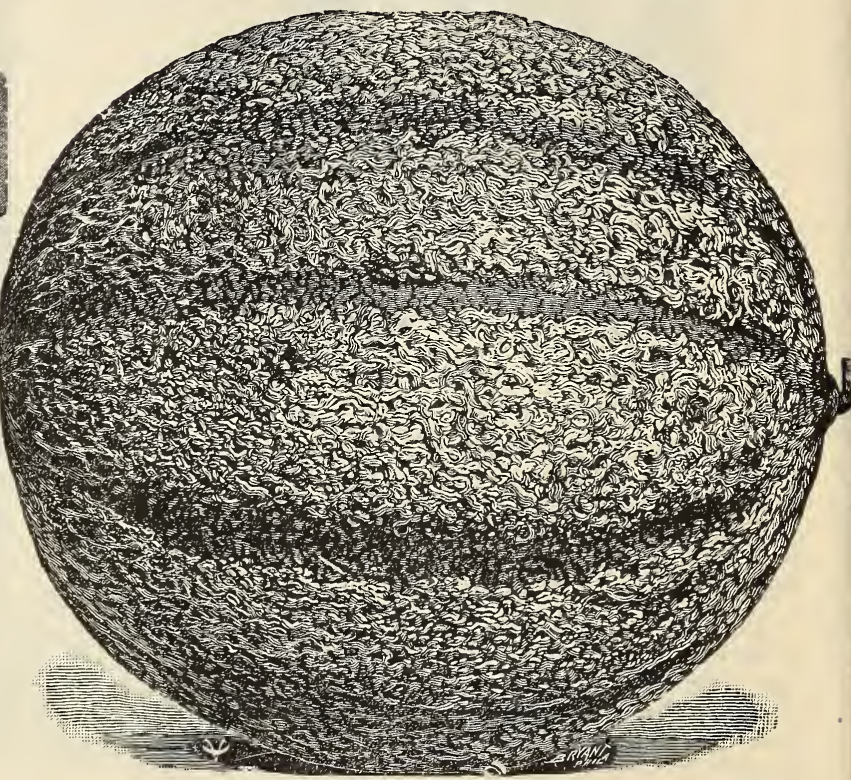

Nagy Kantalup-Sárgadinnye 


\section{GÖRÖGDINNYÉK.}

TENYÉSZTÉSE: Ezek épp ugy, mint a sárgadinnyék, halmokba vagy fészkekbe vetendők, trágyával jól elkészitett földbe.

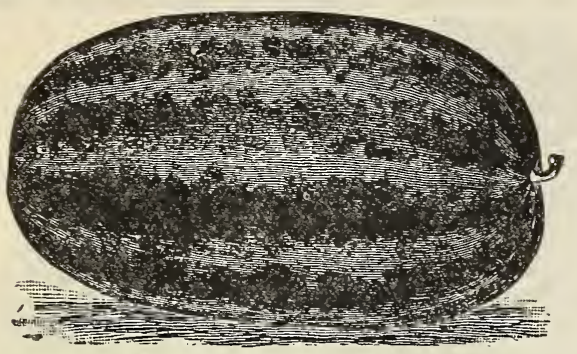

Jaj Be Jó Görögdinnye

KÁLLAY-FÉLE PIROS FAGYLALT GÖRÖG. DINNYE. Legujabb és legkitünőbb görög diny. nyék egyike. Hosszu, ovális alaku, néha 2 láb hosszura növő faj. Husa vérpiros, olvadós és édes izü, ami pedig legjobban emeli értékét az, hogy annyira korai, hogy a mag vetése után 65 napra beérik. Adag 10c; ounce 25c; $1 / 4$ font $70 \mathrm{c} ; 1$ font $\$ 2.00$.

JAJ BE Jó. Az összes görögdinnyék között a legkorábbi, kitünő, édes izü, husa sötétskarlát és olvadós, akár a fagylalt. Héja igen vékony és minden éghajlat alatt sikeresen termelhetö. Adag 10c; ounce (1-16 font) $15 c$; $1 / 4$ font $35 c$; 1 font $\$ 1.25$.

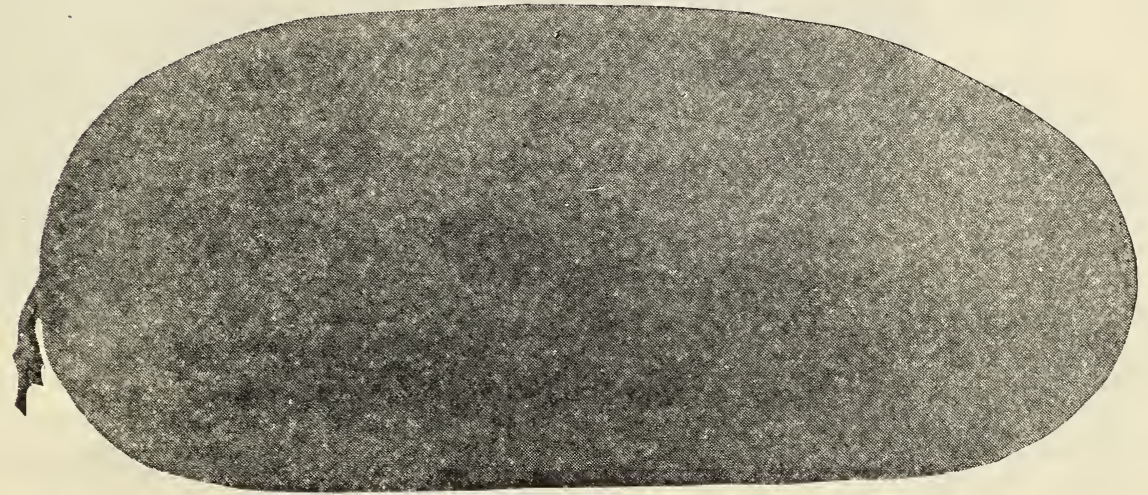

Watson -féle

WATSON-FÉLE ÓRIÁS. Roppant nagyra növő, sötétzöld szinü, bőtermő görögdinnye faj. Husa élénk vérpiros, fagylaltként olvadó, a legfi nomabb izzel. Tagadhatatlanul a legjobb görögdinnye. Adag 10c; ounce (1-16 font) $20 c$; $1 / 4$ font $50 c$; 1 font $\$ 1.50$.

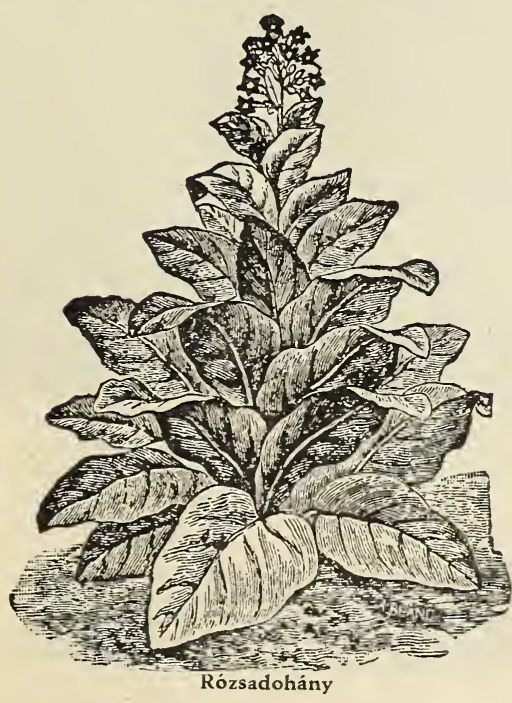

ÉDES ALABAMAI. Óriási nagyságra növő és. a legjobb görögdinnye faj házi kertek részére. Alakja hosszu és vastag. Remek piros szinü, kellemes hüsitő izü hussal. Nagyon bötermö. Adag. 10c; ounce (1-16 font) 20c; $1 / 4$ font $40 c$; 1 font $\$ 1.25$.

\section{DOHÁNY-MAG.}

TENYÉSZTÉSE: Finomul elkészitett könnyü földbe vetjük a magot melegágyba, vagy boxba, amit szintén védett helyre helyezünk $\mathrm{el}$, ahol nedvesen tartjuk. A zsenge növényeket ritkitjuk, mikor pedig már eléggé megerösödtek, kiültetjük kö. vér, porhanyó, napos fekvésü földbe, 4-5 láb távolságnyira egymástól.

RÓZSADOHÁNY. Majdnem megegyezik a magyarországi muskotály dohány minőségével. Nagy leveleket fejleszt, amelyek kitünő illatuak. Adag 10c; ounce (1-16 font) 50c.

HAVANNAI. Havannai dohányfaj. Remek, szép nagy leveleket hoz. Kitünő ugy szivarok gyártására, mint felvágva pipába. Finom és zamatos. Adag 10c; ounce (1-16 font) 60c. 


\section{VÖRÖSHAGYMA.}

TENYÉSZTÉSE: A hagyma mag, mihelyt az idő alkalmas arra, kora tavaszon elvetendõ. Vessük a magot egy láb távolságnyira fekvő hoss zu sorokba, jól megmunkált földbe. A hagymafélék a régebb trágyázásu talajt kedvelik; friss trágyázott földben szárba nőnek. A hagyma egyike azon kerti veteményeknek, amelyet Amerikában nagyban termelnek és belöle a termelök sok pénzt csinálnak.

\section{DIJNYERÖ VÖRÖS HAGYMA.}

Jeles vörössárga, Magyarországon nagy ban termelt Mauthner-féle zittanihoz ha sonlitható kemény, óriási nagyra növő és felette jövedelmező hagyma fajta, nagybani termelésre különösen ajánlható. Nemcsak a jó ize, hanem a jó eltarthatósága adja meg e hagymának nagy becsét, amennyiben jól megérett hagymák a késő tavaszig eltarthatók. Házi kertek részére nagyon becses. - Adag 10c; ounce (1.16 font) $35 \mathrm{c} ; 1 / 4$ font $\$ 1.00$; 1 font $\$ 3.00$.

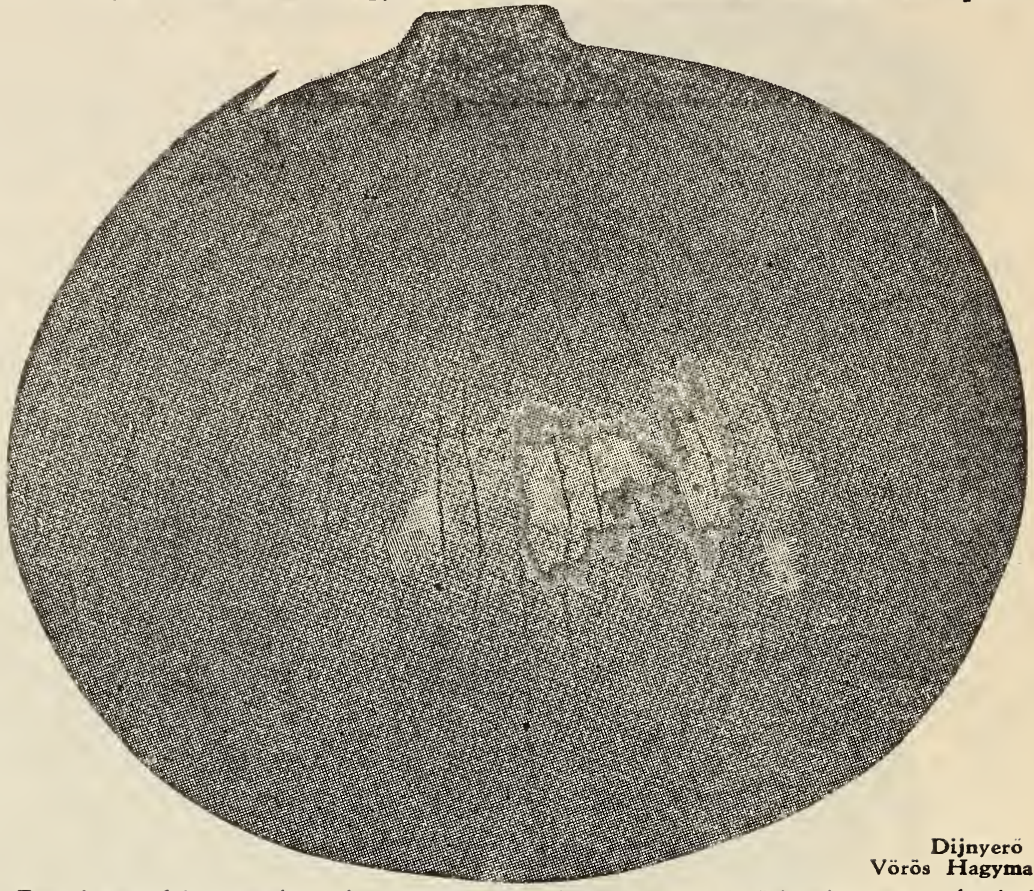

KEREK VERVÖRÖS. Ezen hagymafaj magvetése után 110 napra beérik és a gyönyörü sötét szine nagyon kapóssá teszi a piacokon. Kitünően eltartható télen, a husa nagyon kemény és édes, nagyon bötermő és házi használatra kitünő. Adag 10c; ounce (1-16 font) $30 c ; 1 / 4$ font $90 c ; 1$ font $\$ 2.50$.
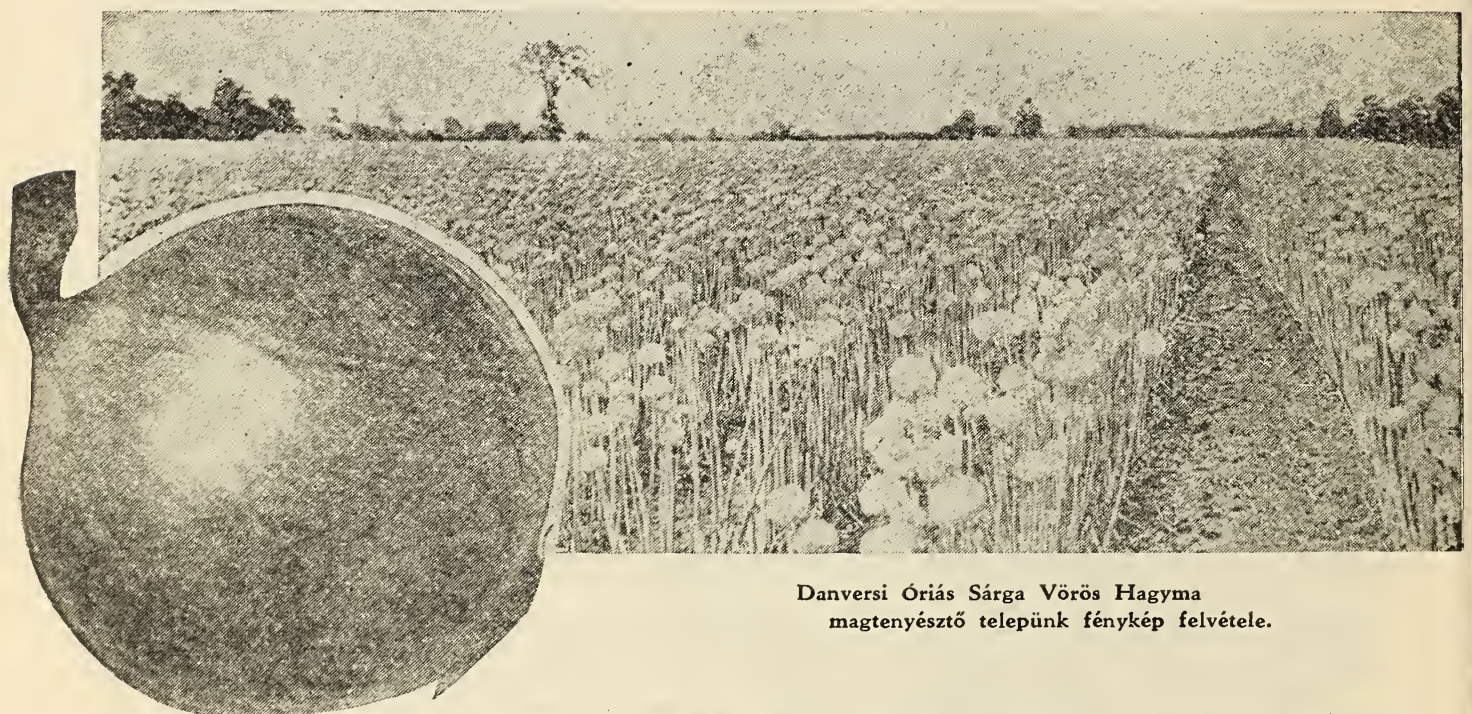

\section{Danversi Óriás Sárga Vörös Hagyma magtenyésztő telepünk fénykép felvétele.}

DANVERS ÓRIÁS SARGA. Óriási nagyra növő jeles amerikai vörös-sárga hagymafaj. A legnagyobb hasznot haj. tó és legbőhozamubb. A piaci termelök legjobban kedvelik ezen fajt az összes hagymák között, amelyböl a mi magunk van termelve, az mind kézzel válogatott és csak azon hagymák, amelyek megfelelnek ugy nagyságnak, mint gömbölyüségnck. Ezen hagymafaj vetése által a hagymatermelök évente 5-700 bushelt tenyésztenek holdankint, amerikaszerte termelt hagymafaj nagybani termelésre. Adag 10c; ounce (1.16 font) 25c; 1/4 font 80c; 1 font $\$ 2.50$. Expresszent 10 font $\$ 22.50$. 
OHIOI SÁRGAGÖMB VÖRÖS HAGYMA. Ohioban nagyban termelt hagymafaj. A legelsőbb rendü hagymát adja, miért is hagymatermelöknek nagyon ajánlható faj nagybani termelésre. Szép, nagy, kemény és sokáig eltartható hagymákat zsolgáltat. Adag 10c; ounce (1.16 font) $25 \mathrm{c} ; 1 / 4$ font $80 \mathrm{c} ; 1$ font 2.50 . Expressen 10 font $\$ 22.50$.

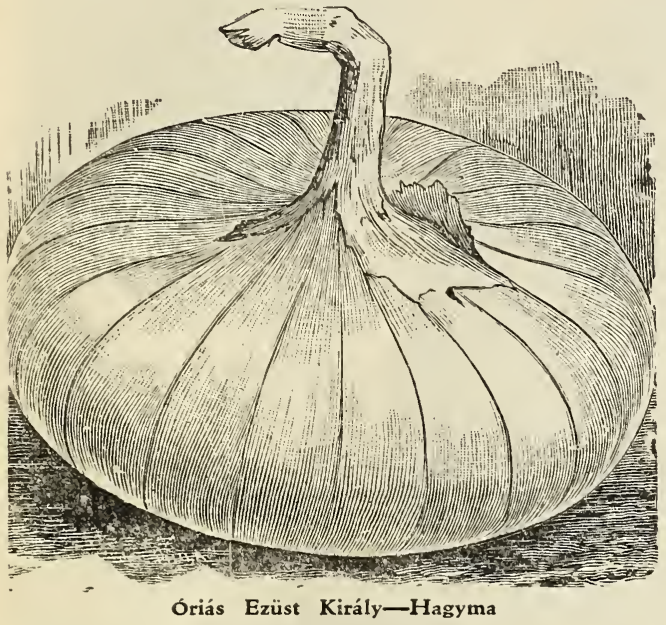

ÓRIÁS EZÜST KIRÁLY. A legnagyobbra növő fehér héju és husu vöröshagyma faj. Husa nagyon enyhe és édes. Igen ajánlatos házi kerteknek és piaci eladásra. Adag 10c; ounce (1.16 font) $35 \mathrm{c} ; 1 / 4$ font $\$ 1.00 ; 1$ font $\$ 3.00$. Expresszen 10 font $\$ 27.50$.
FEHÉR BARLETTA. Nagyon korai középnagyra növő fehér-vörös hagymafaj. Zölden asztali használatra csemege. Mint téli hagymának is alkalmas. Ezen fajhagymát az amerikaiak nagyban használják, ecetben, éppen ugy, mint az ugorkát. Husa szagtalan és édes enyhe izü. Adag $10 c$; ounce (1.16 font) 30c; $1 / 4$ font $\$ 1.00 ; 1$ font \$3.00. Expressen 10 font $\$ 27.50$.

FEHÉR PORTUGAL. A hagyma gumók laposak és magvetése után 75 napra beérik és nagyon ajánlható azon éghajlatokra, ahol a szezon rövid. Ugy asztali használatra, mint piaci termelésre kitünő és zölden használva meg felülmulja az összes hagymafajokat, ecetben pedig ép. pen ugy használható, mint az ugorka. Adag 10c; ounce (1-16 font) $30 \mathrm{c} ; 1 / 4$ font $\$ 1.00 ; 1$ font $\$ 3.00$. Expresszen 10 font $\$ 27.50$.

\section{FOKHAGYMA.}

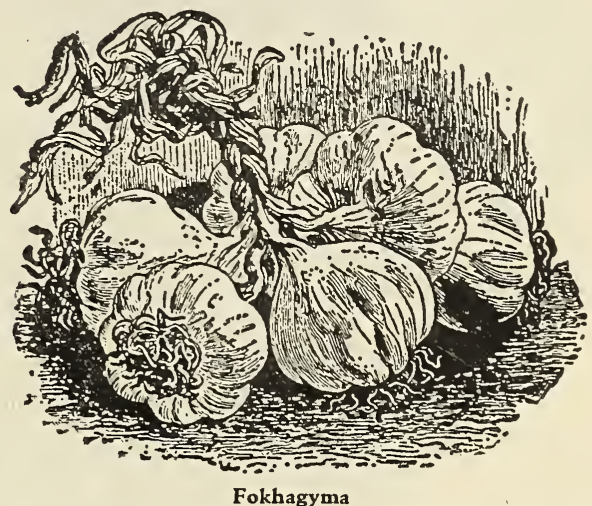

NAGY GEREZDÜ. Legjobb magyar faj ugy házi használatra, mint nagybani termelésre. $1 / 2$ font $25 c ; 1$ font $40 c$. Expresszen 35 c fontja.

\section{DUGHAGYMÁK.}

TENYÉSZTÉSE: Jól megásott talajban tavasszal, mihelyt lehetséges, eldugdosandók a dug. hagymák, egy láb távolságbani hosszu sorokban. Minél korábban eldugdossuk öket, annál korábban nyerünk finom, élvezhetö apró hagymát belölük.

SÁRGA. Sürü vetésből nyert, a magyarországi hires makói hagymához hasonló hagymácskák. Kora tavaszon kitünő zöld hagymát és ugyszintén gazdasági célokra a legizletesebb hagymát szolgáltatja. Általánosan ismert és ugy házi használatra, mint piaci termelésre nagy hasznot hozó faj. 1 font 35c. Expresszen 10 font és azon feliil 25 c fontja.

FEHÉR. Korán élvezhető jeles amerikai faj. Finom fehér husa miatt kitünó asztali használatra. 1 font 40c. Expresszen 10 font és azon felül 30 c fontja.

EGYPTOMI ÉDES. Ugy zöldbeni használatra, mint télire elsőrendü hagymafaj. Kifejlett, nagy, kemény husu hagymát szolgáltat. 1 font 40c. Expresszen 10 font és azon felül 30c fontja.

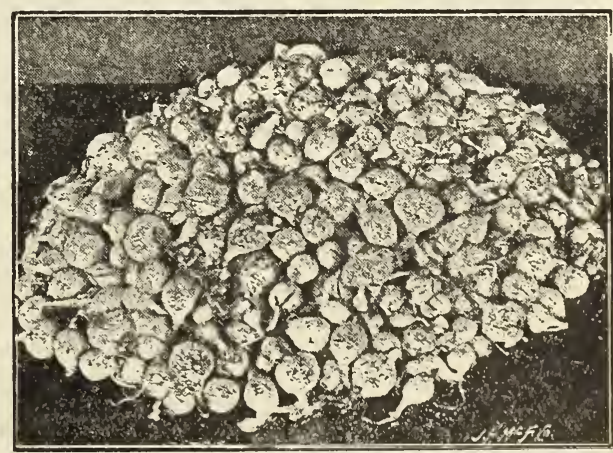

Dughagyma 


\section{PÓRÉ-HAGYMA.}

TENYÉSZTÉSE: Épp ugy, mint a vörös hagymáé, ez is korán vetendo, de egy kicsit tá volabb teendők a sorok egymástól.

ÓRIÁSI TÉ. LI. A legkitünőbb faj, korai használatra is ugy, mint télire. Rendkivül gyorsan fejlödik és igen jól eltartható. A legjobban ajánlható faj.Adag 10c; oun ce (1-16 font) 30c.

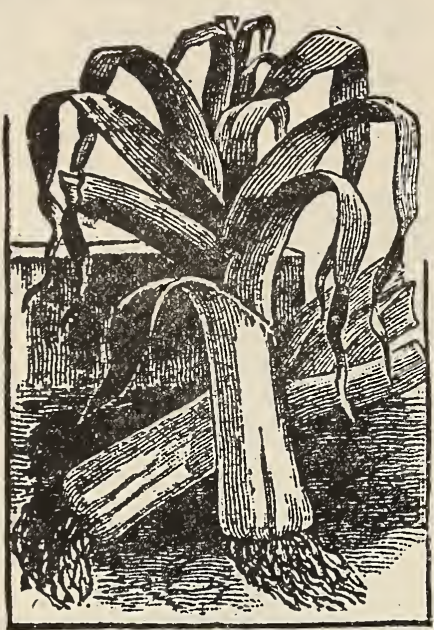

Póré-Hagyma

\section{METÉLÓ.HAGYMA.}

SNIDLING. Mihelyt a kis növényt megkapja, azonnal ültesse edénybe jó földben és télen tartsa a házban világos helyen, nyáron pedig ki lehet ültetni a szabadba és télen ismét a házban tartjuk és egész télen lehet használni evéshez. Cserép bỏl palánták: 1 darab 15c;

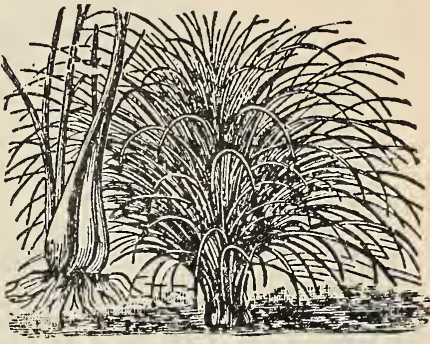

10 darab $\$ 1.25$

Snidling

\section{FEJES KÁPOSZTÁK.}

TENYÉSZTÉSE: A korai fajok február végén, március elején, ha lehet, melegágyba, a késői (téli) fajok áprilisban a szabadban szórva-vetve veteményezendók. A palánták megerősödtével kiültetendők két láb távolságbani hosszu sorban, $11 / 4$ láb távolságba ültetve őet. Bőven trágyázott talaj, öntözés és ápolás a káposzta tenyésztés legfőbb kellékei.

\section{KORAI KÁPOSZTA. UJDONSÁG!}

ARANY-HOLD (Golden Acre). Ezen kitünő uj faj a legkorábbi gömbölyü fejü káposzta, 7 nappal előbb vágható, mint a Copenhágai piaci, vagy a Cukor Süveg, az egész Amerika legkorábbi káposztája. Ezen uj faj káposzta Hollandiában volt fajoztatva, a nagyban ismert Copenhágai Piaciról és ahol 1 kilót a sulyról vesztettek, ott 7 napot nyertek a koraiságán és csak 2 éve, hogy ezen mag kapható Amerikában. Az Arany-Hold káposzta fejek teljesen gömbölyüek és igen kemények, a fejek közép nagyok vagy 4 kiló sulyuak és nagyon keskeny külső levelei vannak, tehát ugy házi, mint nagybani termelése igen ajánlható. Adag 20c; ounce (1.16 font) $\$ 1.25 ; 1 / 4$ font $\$ 3.75 ; 1 / 2$ font $\$ 6.50 ; 1$ font $\$ 12.00$.

KOPENHÁGAI PIACI. Mauthner Ȯdön Árjegyzéke ezeket mondja ezen káposztáról:

A legnagyobb tökéletességü és a legjobb gömbölyü fejü korai káposzta, melyet valaha termesztettek. Korai érése és a fejeinek egyenletessége csodálatos. A fejek a sorokban oly egyformán festenek, mintha csak öntvényből kerültek volna ki. Kevés keskeny külső levelei vannak és ezért e fajtát szorosabban lehet egymáshoz ültetni. Fejei közép nagyok, mintegy 5 kiló sulyuak, finom bordájuk tömörek és igen kemények. Ahol egyszer megpróbálják, ott ezen korai káposzta mindenkor kapós lesz. Adag 15c; ounce (1-16 font) $50 \mathrm{c} ; 1 / 4$ font $\$ 1.50 ; 1$ font $\$ 4.00$.

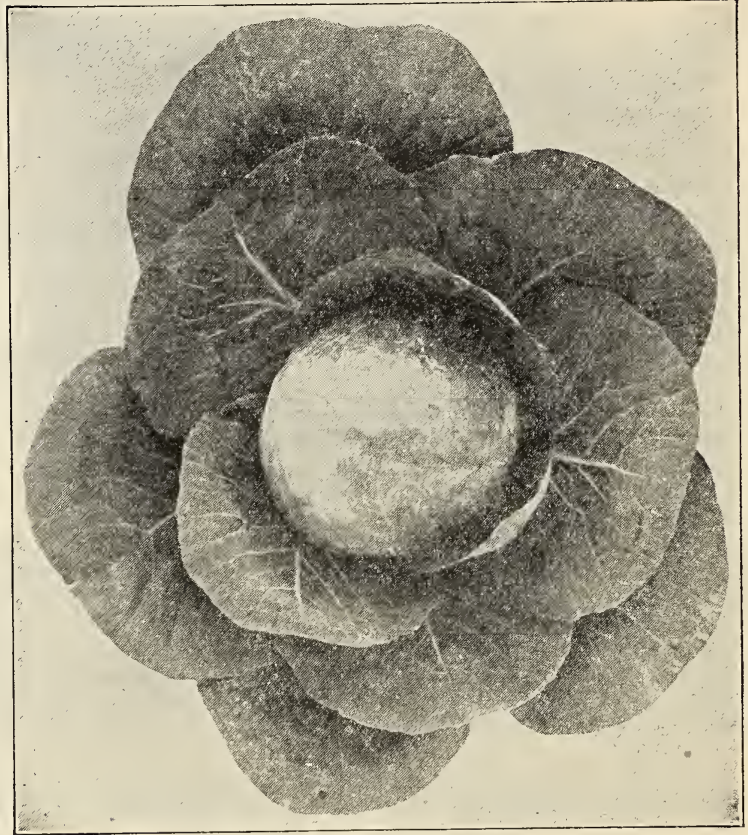

Arany-Hold (Golden Acre)

KORAI NYÁRI FEJES. Legkorábbi, fehér kerek lapos fejekkel. Ezen káposzta faj jó tulajdonságai és koraisága által felülmulja az öszszes más korai fajokat. Adag 10c; ounce (1-16 font) $35 \mathrm{c} ; 1 / 4$ font $\$ 1.25 ; 1$ font $\$ 3.50$. 
JÁNOS NAPI. Korai, kerek lapos, hófehér fejü. Rendkivül zsenge. Nagyon korai. Nagy. bani termelésre is igen ajánlatos. Házi kertekből elmaradhatatlan. Adag 10c; ounce ( 1.16 font) $40 c ; 1 / 4$ font $\$ 1.50 ; 1$ font $\$ 3.75$.
MAUTHNER-FÉLE CUKORSÜVEG. Rendkivül zsenge, korai káposzta faj. Csucsos keményfejü. A legkorábbi ezen fajták között. Ki. tünő családi használatra. Adag 10c; ounce (1-16 font) $35 \mathrm{c} ; 1 / 4$ font $\$ 1.25 ; 1$ font $\$ 3.50$.

\section{KÁLLAY·FÉLE JAVI. TOTT DÁN KÖFEJÜ KÉSEI KÁPOSZTA.}

Több évi kisérletezés után sikerült egy ujabb és tökéletesebb káposzta. fajt előállitanunk, mely felülmulja az összes ed. dig ismert téli káposzta. fajokat s ugy minőségé. nél, mint a gyors növéségénél fogva jeles, kő. kemény fejü, finom izü káposzta faj. Vékony fi. nom, bordás levelei oly keményen fedik egy. mást, hogy semmiféle más káposzta sem gyalulható meg oly fino. man, mint ez és mivel ezen faj nagy leveleket nem fejleszt, hanem a mint a levelei nőnek, azonnal a fejek is fejlöd. nek, ennélfogva ezen faj gyorsabban megfejesül, mint bármely más faj.

Juliusban ületett palánták épp ugy megkeményednek mint más faj, amelyet mar junius elején elültetnek. Hardóban besavanyitásra a legfinomabb az összes kà. poszták közōtt. Adag $15 \mathrm{c}$ ounce ( 1.16 font) $50 \mathrm{c} ; 3 / 4$ font $\$ 1.75,1$ font $\$ 4.00$. b) Késői fajok.

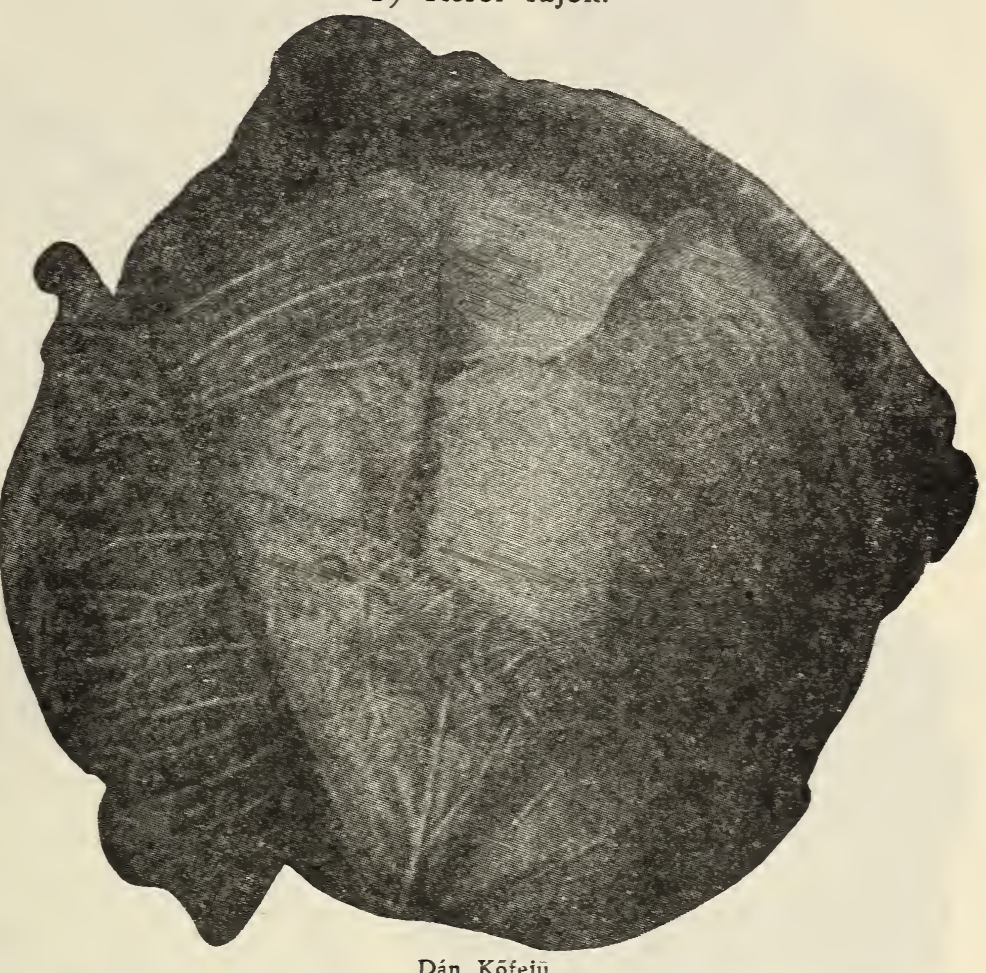

BIZTOS FEJÜ.

Legnagyobb lapos, kerek, keményfe jü, alacsony torzsáju, finom bor. dás; besavanyitás. ra a legalkalma sabb és legtarto. sabb faj. Hazal káposzta fajaink között a leghiresebb; finom leve lü és vékony ber dáju, - levelei cendkivūl tömö: szép, kerekded és nagy fejeket ké peznek. A jó téli káposzták minden tulajdonságait bir ja. Termese min den kōrülmények kōzött biztos, mi ért is nagybani ter melésre igen a. jánlható ezen eredeti, legfinomabb minöségü tiszta mag. Adag 10c: ounce (1.16 ft.) $35 \mathrm{c} ; 1 / 4$ font $\$ 1.00$ 1 font $\$ 3.00$.

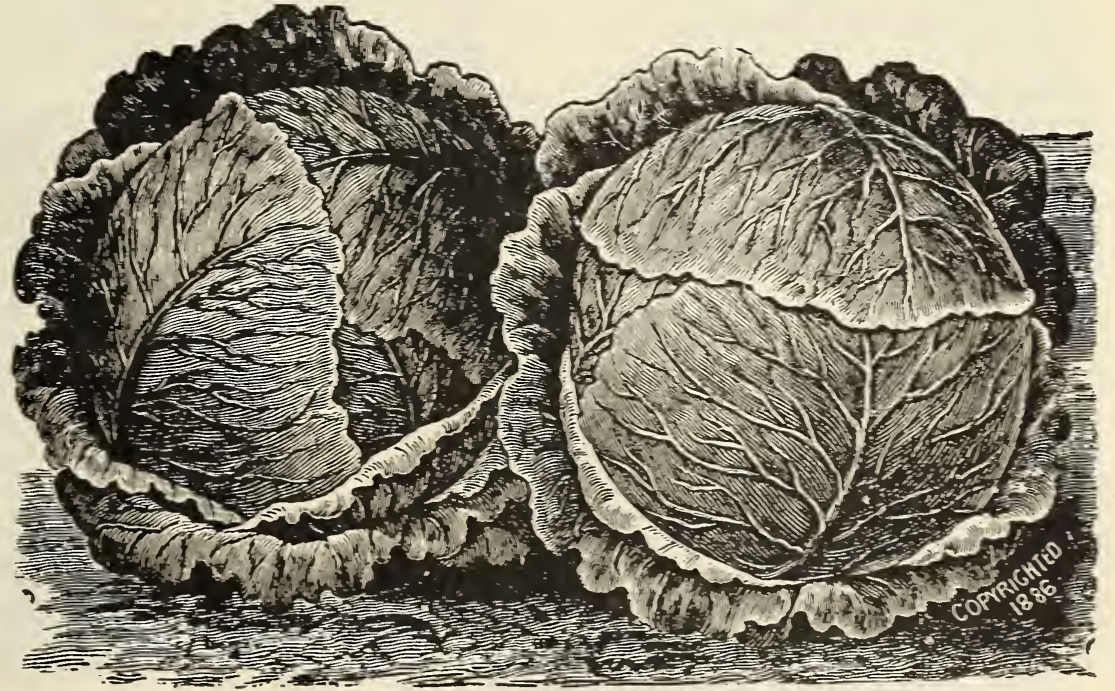

Biztos Fejü Téli Káposzta 


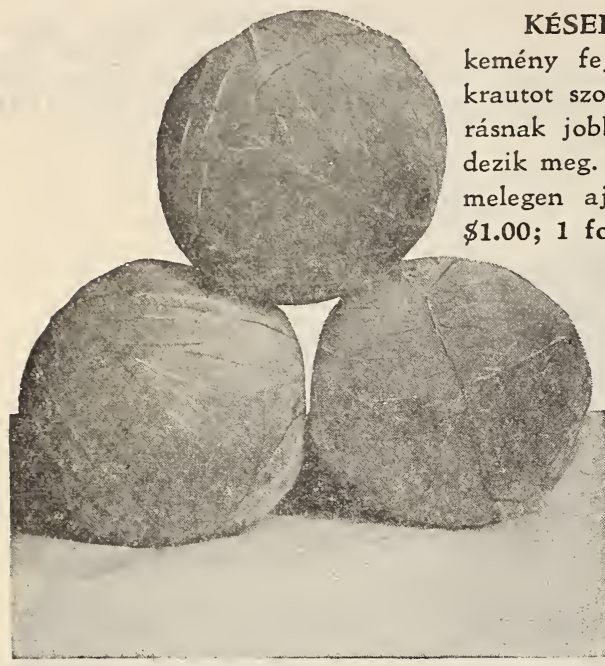

Kései Nagy Keményfejü

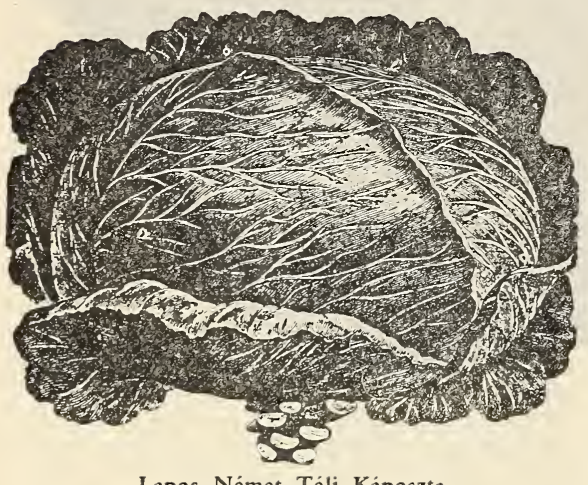

Lapos Német Téli Káposzta

LAPOS NÉMET. Ezen kitünő faj rendkivül nagy fejeket fejleszt és a legjobb izü savanyu káposztát adják, minélfogva hordókbani eltevésre nagyon ajánlható. Adag 10c; ounce (1.16 font) $35 \mathrm{c} ; 1 / 4$ font $\$ 1.20 ; 1$ font $\$ 3.25$.

\section{VÖRÖS KĀPOSZTA.}

TENYÉSZTÉSE: A vörös káposzták oly mivelési módot kivánnak, mint az előbbeni káposzta fajok.

\section{ÓRIÁS SZIKLA-FEJÜ VÖRÖS KÁPOSZ-}

TA. A legsötétebb és legjobb vörös káposzta. A fejek keménysége és tartóssága tulszárnyalja az összes fajokat. Ugy házi használatra, mint piacra való termelésre nagyon aján. latos. Adag 10c; ounce (1.16 font) $50 \mathrm{c}$; $1 / 4$ font $\$ 1.50 ; 1$ font $\$ 4.00$.

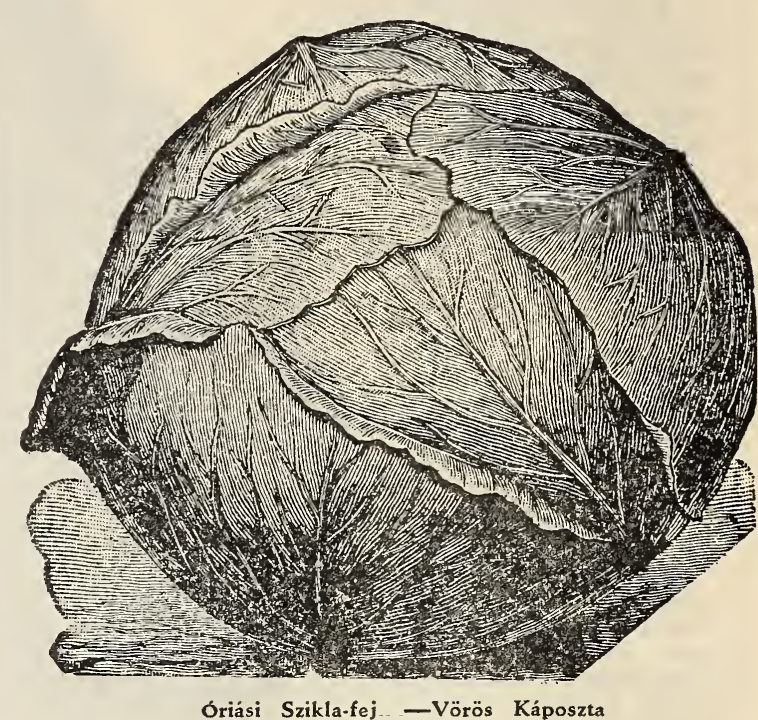

\section{BIMBÓS-KEL.}

TENYÉSZTÉSE: Áprilisban szabad földbe vetendö, később sorokba kiültetjük. Télen át a szabadban maradhat, csak erős hidegben betakarandó kevés szalmával.

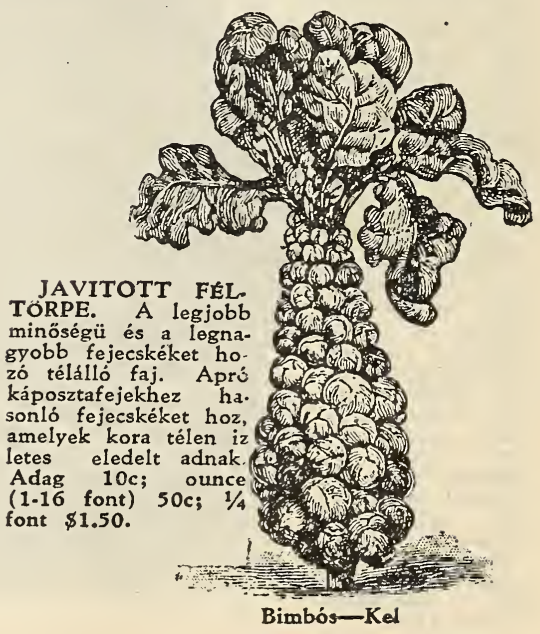




\section{KEL- vagy OLA SZ-KÁPOSZTA.}

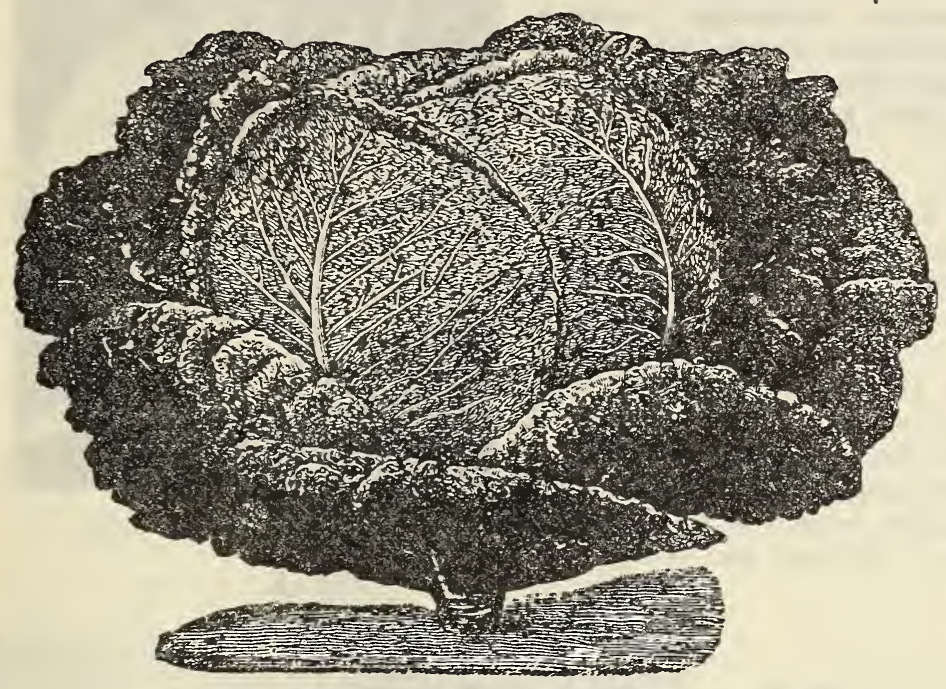

Javitott Vasfej-Kelkáposzta
TENYÉSZTÉSE: Termelése azonos a káposztákéval. A magot korai termelésre márciusban melegágyba, vagy később a szabadba ágyacskákba vetjük, ahonnan, ha a palanták meg. erösödtek, a szabadba kiültetjük. Továbbkezelése egyenlö a többi káposztafajokéval.

JAVITOTT VASFEJÜ. Tagadhatatlanul a legjobb fajta kelkáposzta ugy korai, mint kései termelésre, amely magába foglalja az összes kelkáposzta fajokat. Fejének külsó levélzete zöld, belseje pedig sárga. Nagy és kemény fejekkel. Adag $10 \mathrm{c}$; ounce (1.16 font) 40 cent; $1 / 4$ font $\$ 1.25 ; 1$ font $\$ 3.50$.

\section{KÁRFIOL-VIRÁGOS KEL.}

TENYÉSZTÉSE: Szabad földbeni tenyésztés re ha korán akarunk eloállitani kárfiolt, tanácsos a magot meleg ágyban vetni. A növények megerősödtével, a szabadba, káposzta módjára kiültetjük és tovább kezeljük.

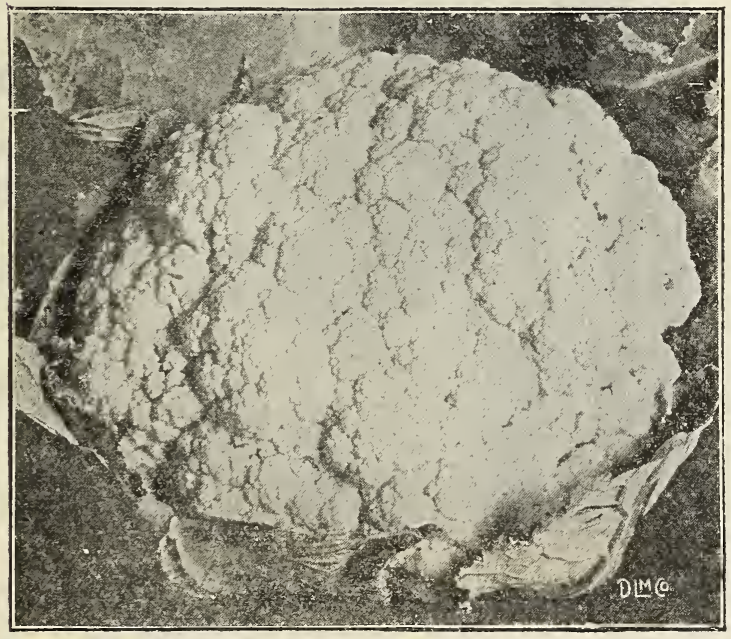

Fehér Rózsa Karfiol

FEHÉR RÓZSA. Középkorai, nagyon könynyen termelhetö faj. Nagy, tiszta fehér, tömött rózsákat fejleszt. Adag 20c; ounce ( 1.16 font) $\$ 1.00 ; 1 / 4$ font $\$ 3.50$.

DAMMANS PRIMUS. Ezen' kitünő kárfiol faj legjobban birja a szárazságot, a fejek óriási nagyok és fehérek, ugy házi, mint piaci termelésre páratlan. Adag 20c; ounce (1.16 font) $\$ 1.00$; $1 / 4$ font $\$ 3.50$.
Sikere biztos, ha a Kállay Testvérek-féle tavaszi vetömagvakat ülteti.

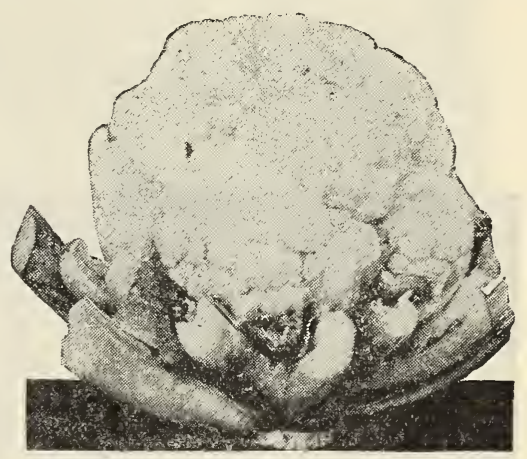

Korai Hólabda Karfiol

\section{KORAI HÓLABDA.}

Kétségkivül a legkitünőbb faj. Ugy szabadbani termelésre, mint hajtatásra. Egyenlö magasságu s nagyon rövid torzsáju, apró levelekkel. Vakitó hófehérségü, nagy fejeket fejleszt. Piaci termelésre páratlan. Adag 30c; 1 ounce (1-16 font $\$ 1.25 ; 1 / 4$ font $\$ 4.00$.

ANGOL KÉSEI. Kései, igen kitünő fajta, erőteljes növéssel és igen nagy, kemény, fehér fejekkel. Nagyon ajánlható. Adag 20c; ounce (1-16 font) $\$ 1.00 ; 1 / 4$ font $\$ 3.50$. 


\section{KALARÁB.}

TENYÉSZTÉSE: A magvak̉ ágyacskạakba vetendők, ahonnan a növények megerősödtével sorokba kiültetjük és tovább kezeljïk a káposztafejek módjára. Kövér, jól trágyázott, verőfényes helyen és gyakori kapálással kapunk igazi kalarábét.

KORAI FEHÉR BÉCSI. Legkoraibb, nagyon zsenge husu, kedvenc üveg kalaráb. Igen gyorsan fejt szép középnagyságu gumókat. Adag 10c; ounce (1-16 font) 35c; $1 / 4$ font $\$ 1.00$.

KALARÁB TÉLI FEHÉR GólIÁT. Ezen óriási nagyságra fejlődő kalaráb a legizletesebb az összes kalaráb-fajok között és oly óriásira fejlödik, hogy néha 4-6 fontot is elnyom. Nagyon izletes, szálkamentes, el lehet egész évig tartani. Bármikor a piacon nagyon kelendő és magas árat fizetnek érte. Adag $15 \mathrm{c}$; ounce (1-16 font) $40 \mathrm{c}$; $1 / 4$ font $\$ 1.25$.

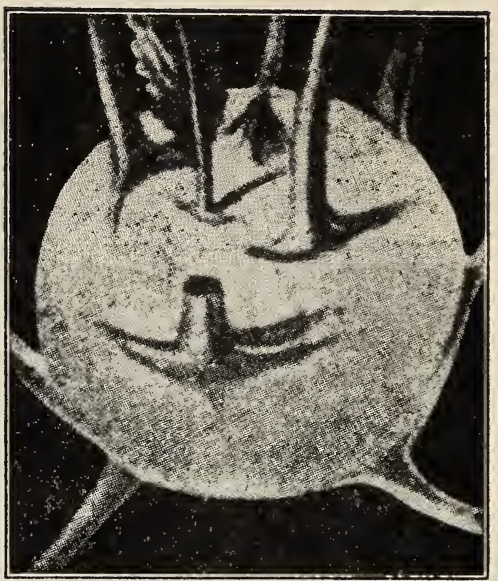

Kalaráb, Téli Fehér Góliát MÁK.

KÉSEI KÉK ÓRIÁS. Legismertebb téli kalaráb, melyet már évtizedek óta nagyban termelnek az összes európai nemzetek zöldség termelői piaci használatra. Rövid idő alatt néha 8-12 hüvelyk átmérőjü nagyság. ra fejlődik. Teljesen szálkamentes, nem üreges és nem pudvásodik meg. Tavaszig is eltartható. Adag 10c; ounce (1-16 font) $30 c ; 1 / 4$ font $\$ 1.00$.

KORAI KÉK BÉCSI. Igen izletes és finom izü korai kék üvegkalaráb. Husa zsenge és finom. Adag 10c; ounce (1.16 font) $35 \mathrm{c} ; 1 / 4$ font $\$ 1.00$.
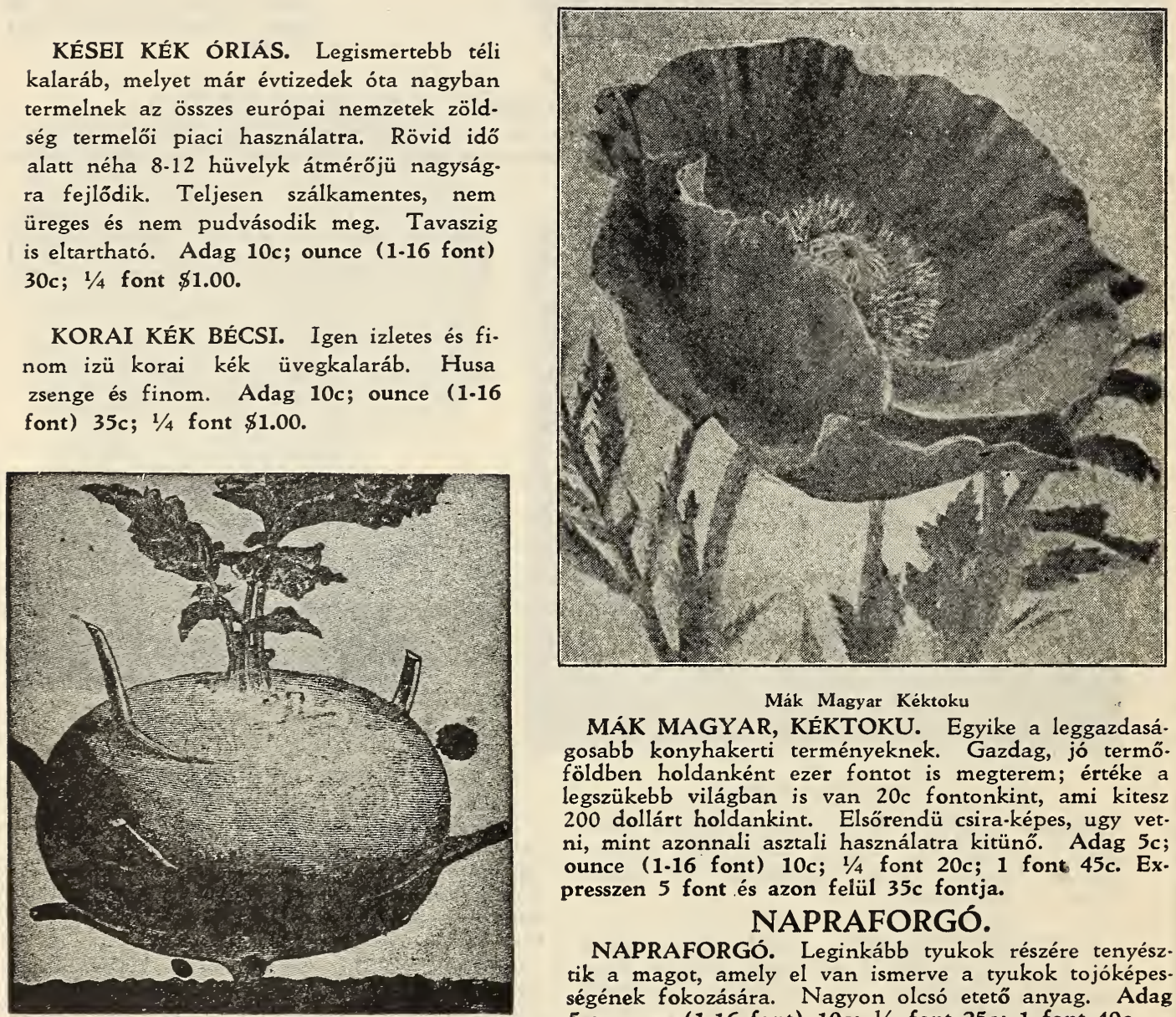

Mák Magyar Kéktoku

MÁK MAGYAR, KÉKTOKU. Egyike a leggazdaságosabb konyhakerti terményeknek. Gazdag, jó termő. földben holdanként ezer fontot is megterem; értéke a legszükebb világban is van $20 \mathrm{c}$ fontonkint, ami kitesz 200 dollárt holdankint. Elsőrendü csira-képes, ugy vetni, mint azonnali asztali használatra kitünó. Adag 5c; ounce ( 1.16 font) $10 c ; 1 / 4$ font $20 c ; 1$ font $45 c$. Expresszen 5 font és azon felül 35 c fontja.

\section{NAPRAFORGÓ.}

NAPRAFORGó. Leginkább tyukok részére tenyésztik a magot, amely el van ismerve a tyukok tojóképességének fokozására. Nagyon olcsó etető anyag. Adag $5 s$; ounce (1.16 font) $10 c ; 1 / 4$ font 25 ; 1 font $40 c$.

Kalaráb, Kozai Kék Bécsi 


\section{PASZTINÁK.}

\section{TENYÉSZTÉSE :}

A pasztinák megnő bármely földben, de ha szép példányokat óhajtunk elöállitani, ugy jól megtrágyázott talajba kell elvetnünk a magot, egy láb távolságbani so rokban. Vethető ? mily korán csak lehe: a tavaszon.

\section{NAGY SIMA.}

Nagy, vastag gyökerü pasztinák, nagyon édes izzel. Adag 10c; ounce (1.16 font) 20c; $1 / 4$ font 40 c; 1 font $\$ 1.25$.

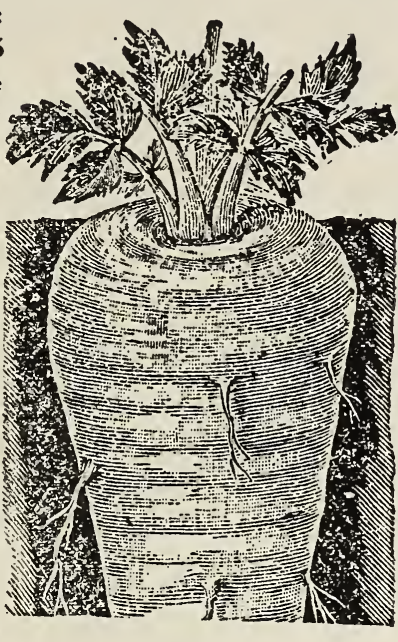

Pasztinák

\section{GYÖKÉR}

\section{PETREZSELYEM.}

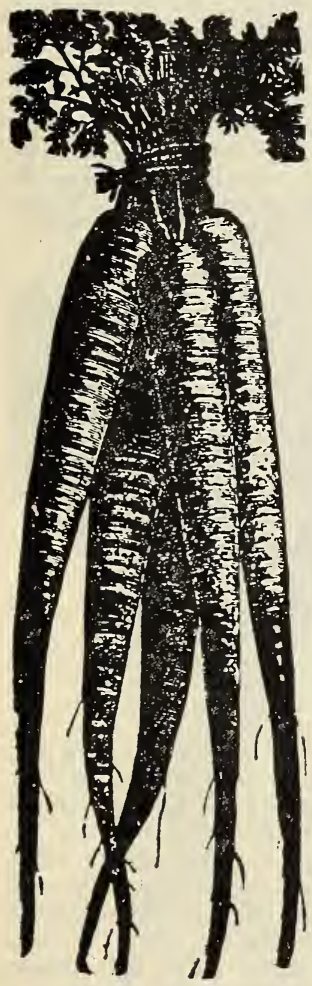

Félhosszu Magyar Petrezselyem

TENYÉSZTÉSE: A petrezselyem legjobban diszlik porhanyó, gazdag földben, de megterem az agyagban is. A magot egy láb távolságban, hosszu sorokban vessük. Van rá eset, hogy a mag néha hoszszu idó alatt csirázik ki a földben és soká kél ki, azért elvethetjük jó korán tavasszal, mihelyt az idő engedi.

\section{FÉLHOSSZU ÉDES} MAGYAR. Cukorédes, félhosszu és vastag gyökerü faj, ugy korai, mint kései használatra a legjobb. Idejekorán vet ve, már augusztus elején élvezhető. Jól bevermelve késő tavaszig eláll. Adag 10c; ounce (1.16 font) $25 \mathrm{c} ; 1 / 4$ font 50c; 1 font $\$ 1.75$.
MOHA LEVELŨ. Mohaszerü fodros levélzettel, amelyet tálak diszitésére használnak. Adag $10 \mathrm{c}$; ounce (1-16 font) 25c.

Az adagonkint hirdetett magvakból fél adag nem adható.

\section{PAPRIKA.}

TENYÉSZTÉSE: Vessük korán a magot melegágyba, vagy a tavasz közepén ki ágyacskákba, könnyü meleg földbe. A növények, ha már elég. gé erősek, kiültetendők 2 láb távolságra fekvő sorokba, egy és fél láb messzeségre egymástól.

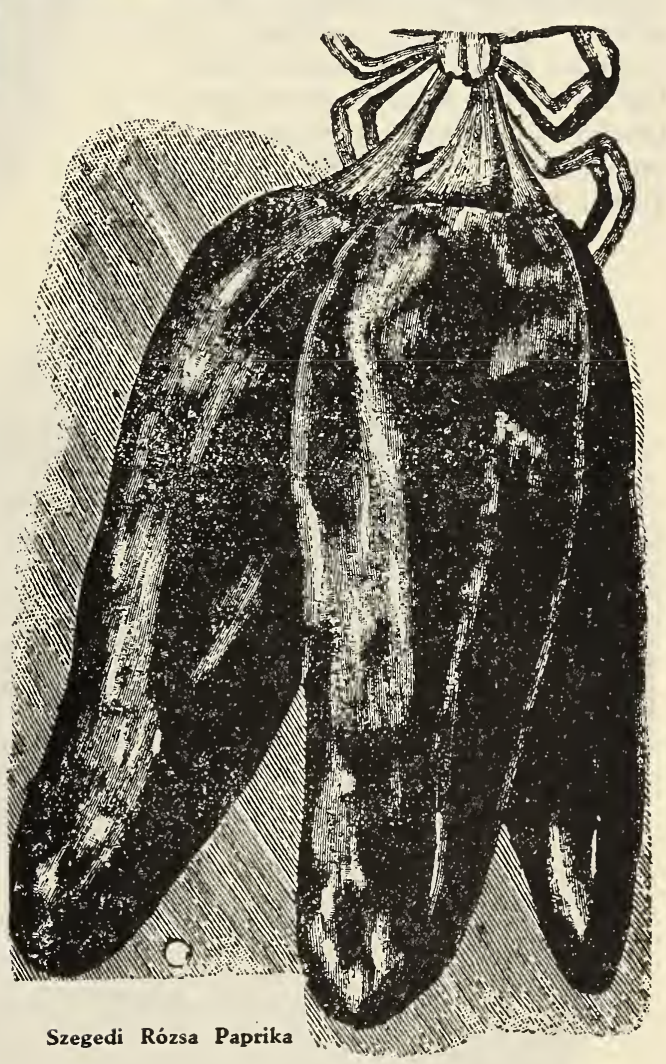

SZEGEDI RÓZSA PAPRIKA. Valódi Szegedi Paprika, frissen hozatott mag. Zölden ecetben magyar ember kitünő eledele hus mellé, száritottan törve pedig kitünõ izt és gyönyörü szint ad az ételnek. Adag 15c; ounce (1.16 font) $75 \mathrm{c} ; 1 / 4$ font $\$ 2.50 ; 1$ font $\$ 7.00$. 


\section{Világ Bajnoka Édes Paprika}

VILÁG BAJNOKA ÉDES PAPRIKA. Ezen faj javitott válfaja a Kinai Óriás Édes Paprikának. Gyümölcsnagysága ugyan nincsen akkora, mint a $\mathrm{Ki}$ nai Óriásé, de husa sokkal vastagabb, édesebb és izletesebb. Gyümölcse kifejlödik akkorára, mint a Kinai Óriás Paprikáé és bővében gyümölcsözik, ennélfog. va nagyon gazdaságos ugy házi használatra, mint piaci termelésre. Nagyban termelik télire ecetben való eltevésre. Egyike a legjobbaknak töltött paprika használatra szabályos nagysága és fenséges édes izénél fogva. Ezen fajt ne tessék az idei veteményes kertböl kifelejteni. 1 adag 15c; ounce (1-16 font) $\$ 1.00 ; 1 / 4$ font $\$ 2.50 ; 1$ font $\$ 8.00$.

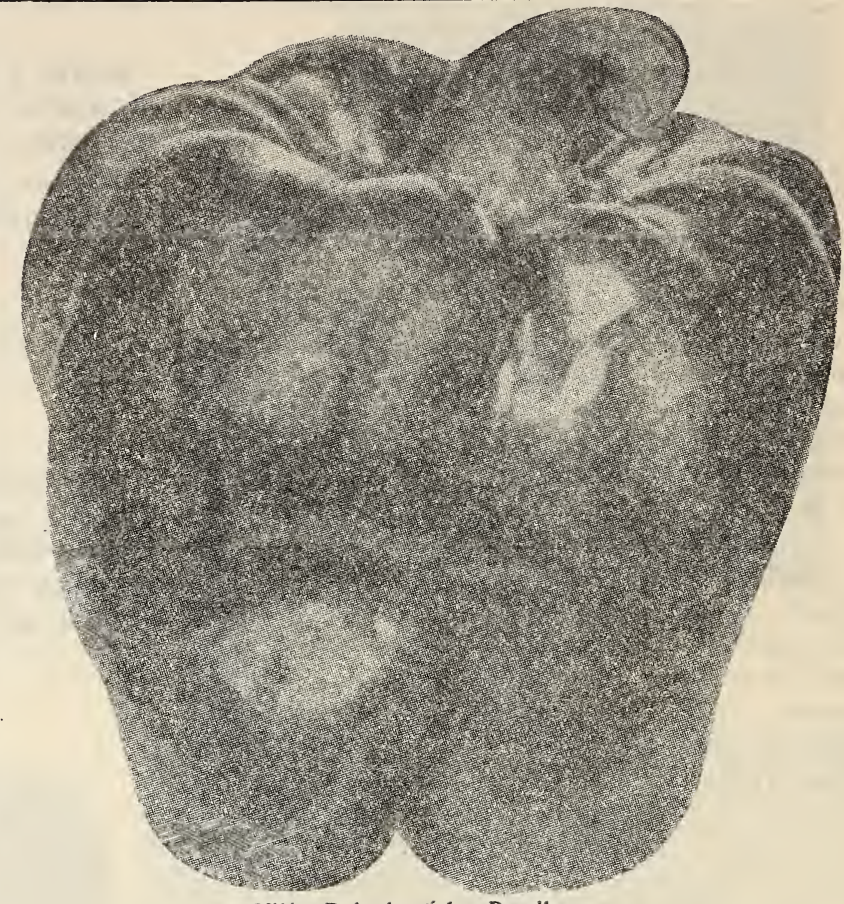

Világ Bajnoka Édes Paprika

NAGY HARANG. Igen nagy, majdnem négyszög alaku Paprika, a vége tompa, $4 \mathrm{col}$ hosszu és $2 \mathrm{col}$ átmérőjü. A növény nagyon erôsen növő és hideg őszig, folyton hozza bő termését. Gyümölcse rendkivül édes és finom izü, husa vastag, töltésre és besavanyitásra igen becses. Adag 10 cent; ounce ( $1-16$ font) $75 \mathrm{c} ; 1 / 4$ font $\$ 2.00 ; 1$ font $\$ 7.00$.

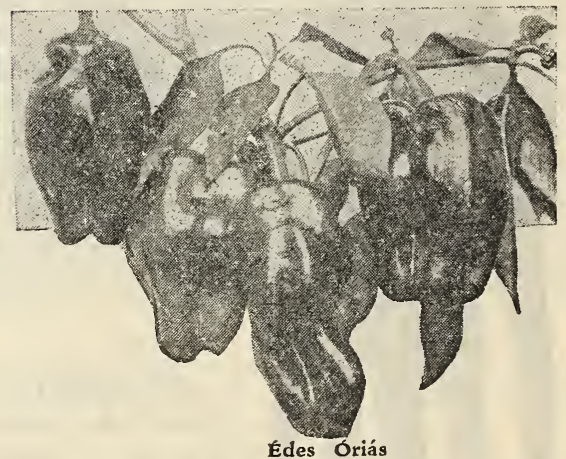

ÉDES ÓRIÁS. Ezen faj óriási nagyra fejlödik, nagyban hasonlit a Nagy Haranghoz, gyümölcse sokszor kifejlödik 6 col hosszura és $4 \mathrm{col}$ át. mérö nagyságra. Szine sötét zöld, husa vastag és édes, nagyon bőtermó és korai, a nagybani piaci termelők nagyon kedvelik bötermősége és fen. séges édes ize miatt. Adag 10c; ounce ( $1-16$ font) $75 \mathrm{c}$; $1 / 4$ font $\$ 2.00 ; 1$ font $\$ 7.00$. 


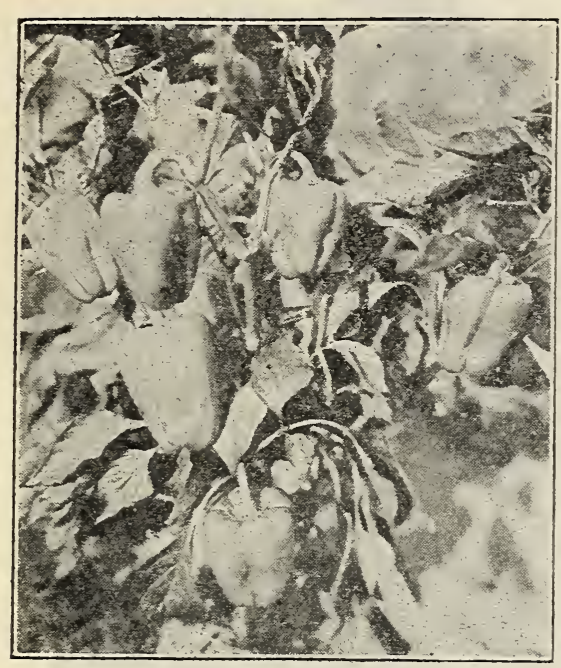

Óriás Sárga

HOSSZU ERÓS. Hosszu gyümölcsü, cseresznye piros és nagyon csipős izü paprika faj. Gyümölcsei vagy 4 col hosszuak és $1 / 4$ col vastagok, végei kissé görbék és nagyon bötermő. Ezen paprika faj egyike a legjobbaknak ugy télire ecetben, mint nyáron levesben, száritottan pedig kitünő izt és szint ád az ételeknek. Adag $10 \mathrm{c}$; ounce (1-16 font) $75 c ; 1 / 4$ font $\$ 2.00 ; 1$ font $\$ 7.00$.

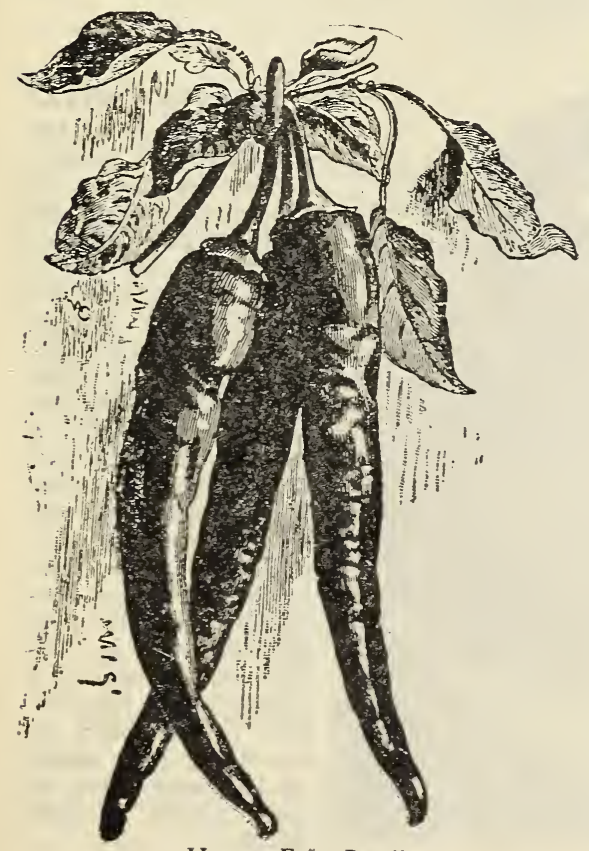

Hosszu Erốs Paprika
PAPRIKA ÓRIÁS SÁRGA. Ezen kiváló sárga paprika faj Svédországból van importálva és a svédországi paprika termelök azt állitják, hogy a legjobb és bőtermőbb az összes sárga paprikák között. A palánták egyenesen növők és teljesen tömve vannak gyönyörü szép sárga paprikákkal. A gyümölcsei óriás nagyok, kifejlödnek 4-5 col hosszura és az ize édes, mint az almáé, ennélfogva mélyen ajánljuk ezen sárga paprikát az összes vevőinknek, mert ugy házi használatra, mint piaci termelésre aranybánya. Adag 15c; ounce (1-16 font) $\$ 1.00 ; 1 / 4$ font $\$ 3.00 ; 1$ font $\$ 10.00$.

ARANYSÁRGA. Roppant nagy és enyhe izü gyümölcsöket fejlesztö, sárga nagy gyümölcsü faj. Adag $10 \mathrm{c}$; ounce (1.16 font) 75 cent.

\section{PARADICSOM.}

TENYÉSZTÉSE: A mag korán melegágyba vagy később ki a szabadba ágyacskákba vetendő, ahonnan az idő fölmelegedtével kiültetjük a növényeket, jól elkészitett, lehetőleg száraz talaju földbe. Három láb távolságnyi sorokban és ugyanily messzeségre tesszük őket a sorokban is.

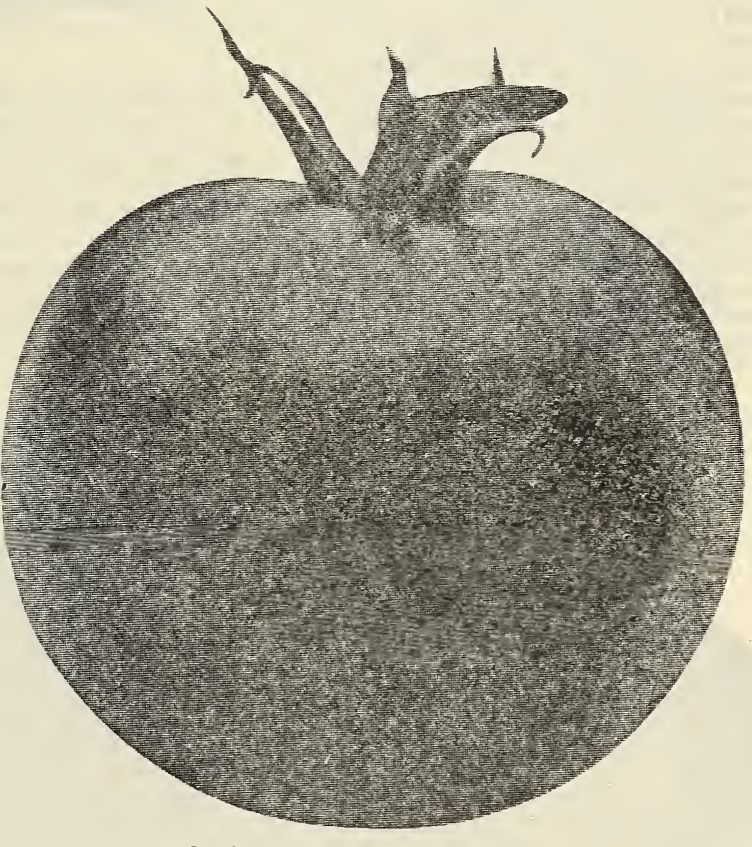

Korai Gyémánt Paradicsom

KORAI GYÉMÁNT PARADICSOM. A legszebb, legkorábbi gyümölcsü, piros, sima paradicsom, melyet valaha termeltünk. Valóságos csoda, rengeteg bötermö, a gyümölcsök tömörek, némely fürtön 25-30 pompás skarlátvörös szinü, nagy paradicsom terem. Ugy a házi kertben, mint a konyhakertészet részére. Aki marketra (piacra) termel, ezen uj paradicsom megfizethetetlen. Tenyésztője, kinél holdankint 1000 dollárt is jöve. delmez, magjának a sulyát az aranyéval becsüli egyen. értékünek. Adag 10c; ounce ( 1.16 font) $50 \mathrm{c}$; $1 / 4$ font $\$ 2.00 ; 1$ font $\$ 6.00$. 
ARANY KIRÁLYNÉ. A sárga gyümölcsü paradicsomot nem termelik oly nagyban, mint a pirosokat, de azért sokan jobban kedvelik, mint a piros gyümölcsüt asztali használatra, mivel hogy nagyon husos és finom izü. Adag 10c; ounce (1-16 font) $50 \mathrm{c}$.

JUNIUSI PIROS. A legjelesebb fajok egyike, szép, formás, kerek gyümölcsöket hoz, igen kevés maggal. Szine gyönyörü rózsaszin, vagyis világos piros. Gyümölcse szinénél fogva a piacon (marketon) mindig magasabb árat hoz, mint bármely más faj, ezért a nagybani zöldségtenyésztők ezen fajt elsőrendünek tekintik. Adag 10c; ounce ( 1.16 font) $45 \mathrm{c} ; 1 / 4$ font $\$ 1.25 ; 1$ font $\$ 5.00$.

LEGKORÁBBI SPẢRK-FÉLE. A legkorábbi, élénk piros szinü paradicsom faj. Gyümölcsei naggyá fejlödnek, amelyek lédusak és a legkelleme. sebb izüek. Befözésre nagyon ajánlható, miáltal a legelső helyet foglalja el házi használatra. Adag 10c; ounce ( 1.16 font) $45 c ; 1 / 4$ font $\$ 1.25 ; 1$ font $\$ 5.00$.

LIVINGSTON GYÖNYÖRE PA. RADICSOM. Ezen gyönyörü szinü és alaku paradicsom csak néhány éve, hogy feltaláltatott, máris oly nagyarányu a kereslet, hogy nem lehet elég magot előállitani a vevőközönség részére. Óriási nagyra fejlödö gömb alaku, sima gyümölcsü paradicsom. Nagyon kevés magja van és ami értékes benne, arányosan érik. Szine finom fényes, világos piros, vagyis lila árnyalattal. Közép korai érésü, nagybani termelésre elsőrendü. Adag 15c; ounce (1-16 font) $55 \mathrm{c} ; 1 / 4$ font $\$ 1.50$; 1 font $\$ 6.00$.

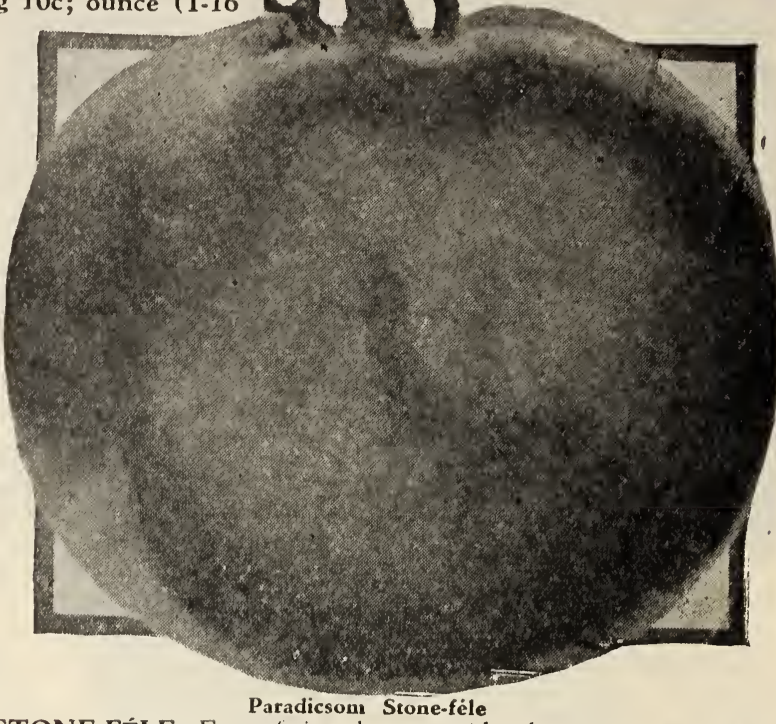

STONE-FÉLE. Ezen taj a legnagyobb alacsony nörô kẻsei paradicsom. Gyönyörü sötét szinü, gömbölyü, kemény gyümölcsei nagyon lédusak. A gyümölcseit mindig fürtökben hozza, 3-5 egy fürtben, 4-inch átmérö és $21 / 2$-inch mély, a gyümölcsök falai vastagok és kemény husu belül és nem oly kemény fehér. gerezdes, mint a többi fajoknál létezik. Egész a fagy beálltáig. folyton fejleszti szép gyümölcseit. A nagybani tenyésztők ezen: fajt a legjobbnak tekintik és a kannázó gyárak is csak ezen fajt használják befözésre. Adag 10c; ounce (1-16 font) 45c; $1 / 4$ font $\$ 1.25 ; 1$ font $\$ 5.00$.

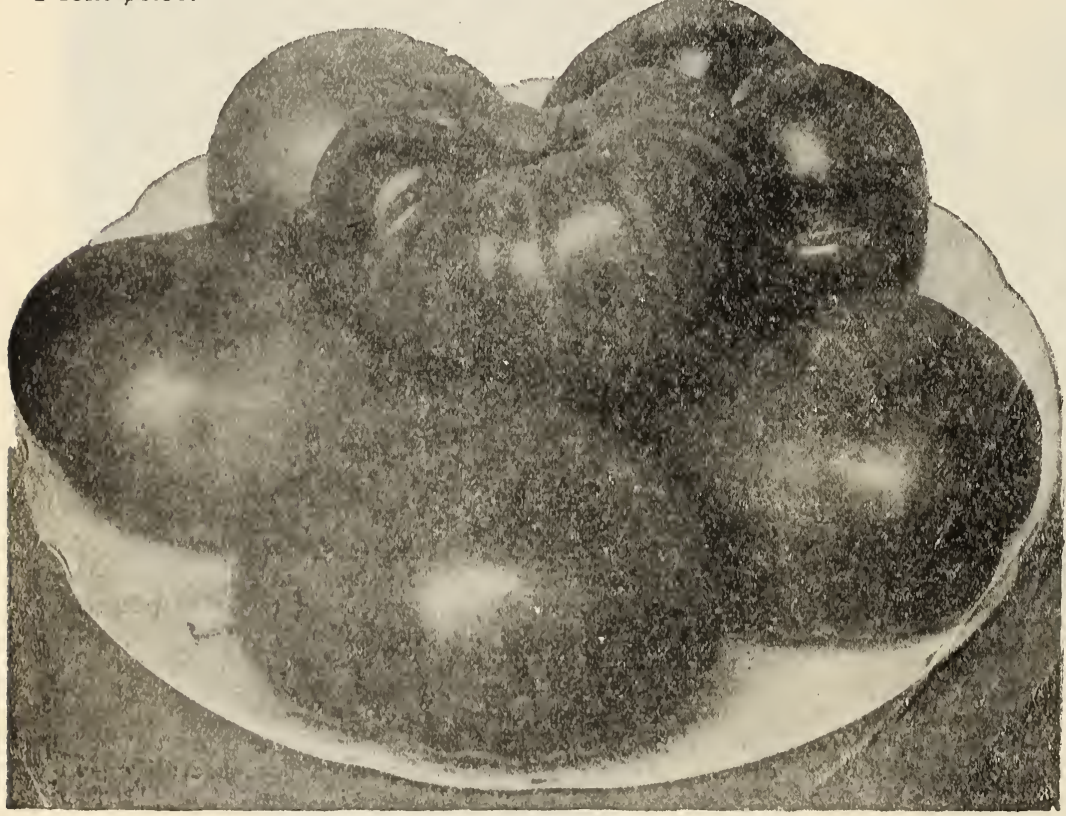

KERTEK KIRA. LYA. Ezen hires faj paradicsom 15 nappal elöbb érik, mint at Stone-féle, gyümölcseï óriási nagyok és kemény husuak és a mag-cellák sokkal kisebbek, mint a más fajokon. Asztali felszeletelésre, mint téli befôzésre felülmulhatatlan. Aki kedveli a nagy paradicsomot, ezen fajt ki ne felejtse kertjéből. Növése nagyon erős és gazdag, egész az ôszi fagyokig folyton hozza szép sötétpiros gyü. mölcsét és ha jé föld. ben van plántálva, a gyümölcsei kifejlôd. nek 1 font sulyra is. - Adag 15c; ounce (1-16 font) $55 \mathrm{c} ; \mathrm{s} / 4$ font $\$ 1.75$; 1 font $\$ 6.50$. 


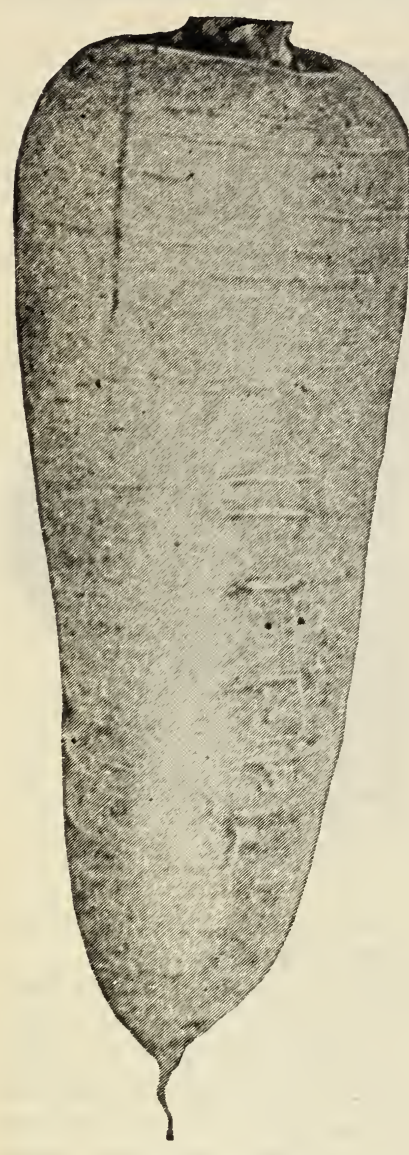

Danversi Félhosszu Sárga Répa

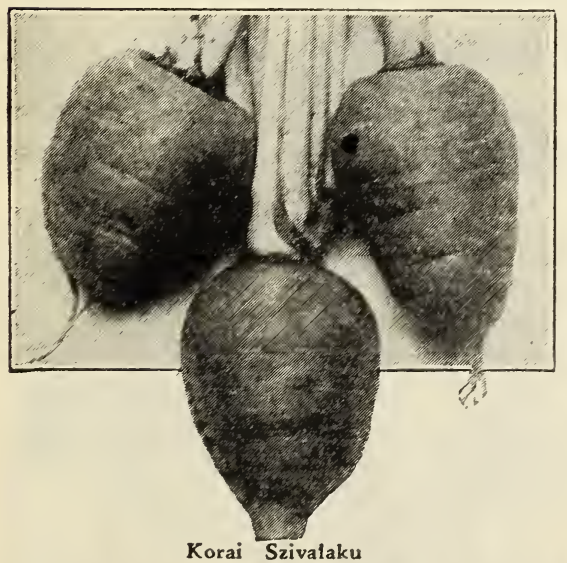

KORAI SZIVALA. KU. Nagyon nagyra növő korai rövid és roppant bötermö faj. Ezen faj nem kivánja meg a jó földet, mint a többi fajok. Nagyon bőven terem nehéz agyagos földben is. Husa narancsvörös zsenge és nagyon izletes. Ugy házi használatra, mint állatok etetésére kitünö. Adag 10c; ounce (1-16 font) $20 c ; 1 / 4$ font $40 c$; 1 font $\$ 1.50$.

BESAVANYITANI VALÓ RÉPA.

TENYÉSZTÉSE: Vessük a magot junius-juliusban két láb távolságra fekvő sorokban. Ritkitást kiván.

NAGY FEHÉR. Legkitünőbb faj ugy asztali használatra, mint állatok etetésére. Adag 10c; ounce (1.16 font) 20c; $1 / 4$ font $35 \mathrm{c} ; 1$ font $\$ 1.50$. 1 font $\$ 1.50$. 30 tonna is terem egy hold földön, tehát marhák etetésére elsóbőtermősége, mint tejtartalmánál fogva. Adag 10c; ounce (1.16 font) $25 \mathrm{c} ; 1 / 4$ font $50 \mathrm{c} ; 1$ font MAUTHNER-FÉLE NANTE-
SI. Igen korai, nagy hengeralaku sárgarépa, a végei tompák és nagyon kevés oldal gyökereket hoz, a husa nagyon édes és a belső csutkája kicsi és vékony. A szine gyönyörü narancssárga és teljesen sima. Ugy Európában, mint Amerikában nagyban termelt piaci cikk. Asztali használatra legjobb az összes sárgaré(1-16 font) $25 \mathrm{c} ; 1 / 4$ font 50c; 1 font $\$ 1.75$.

\section{SÁRGA vagy MUROK RÉPA.}

TENYÉSZTÉSE: Vessük a magot junius-juliusban két láb távol. NAGY FEHÉR. Legkitünőbb faj ugy asztali használatra, mint állatok etetésére. Aadag 10c; ounce (1-16 font) $25 \mathrm{c}$; $1 / 4$ font $50 \mathrm{c}$;

HOSSZU NARANCS. Igen hosszu és vastagra növő fajta. Narancssárga, jóizü hussal. Adag 10c; ounce (1-16 font) $25 \mathrm{c} ; 1 / 4$ font

DANVERSI FÉLHOSSZU. Kiváló jó és nagyon kedvelt téli faj, félhosszu, egyenletesen vastagodó, sima gyökerekkel, amelyek nagyon

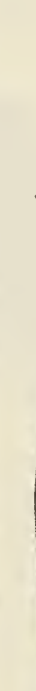

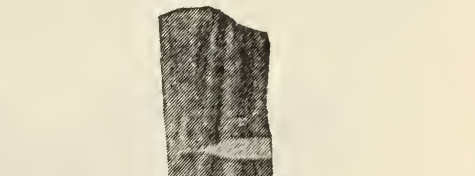




\section{CÉKLA vagy VÖRÖS RÉPA}

TẼNYÉSZTÉSE: A magvakat egy láb távolságnyira fekvő hosszu sorokban kell vetni március-áprilisban. Legjobban diszlik homokos, jól trágyázott, könnyü talajban.

TÜZGOLYÓ. Teljesen rozsdanélküli, nagyon szép gömbölyü alaku cékla-répa. Husa tüzvörös és igen zsenge, nem fásul meg. Adag 10c, ounce (1-16 font) $20 c, 1 / 4$ font $45 c, 1$ font $\$ 1.50$.

DETROITI. Legkitünőbb sötétvörös faj ugy házi használatra, mint marketre való termelésre. Adag 10c, ounce 1 (-16 font) $20 \mathrm{c}, 1 / 4$ font $45 \mathrm{c}, 1$ font $\$ 1.75$.

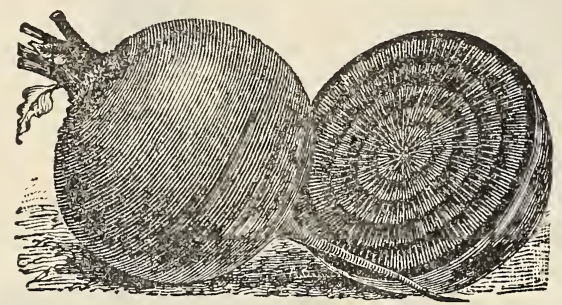

Kései Vérvörös Cékla Répa

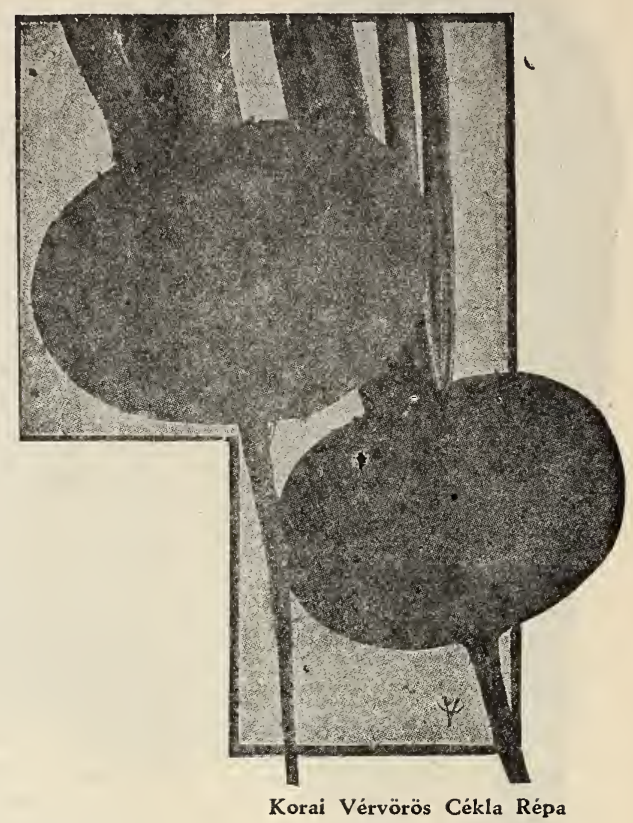

minden bizonnyal vesse kertjében. Adag $10 c$, ounce (1-16 font) $20 \mathrm{c}, 1 / 4$ font $40 \mathrm{c}, 1$ font $\$ 1.50$.

KÉSEI VÉRVÖRÖS. Középkoru, vagy kései zsenge, vörös husu, gyönyörü alaku faj. Teljes egészségesen eláll egész télen hogy ha el van rakva homokban, vagy földben a pincében. A répák nagyon simák, kitünő ugy asztali használatra, mint nagybani termelésre. Adag 10c, ounce (1-16 font) $20 c, 1 / 4$ font 45 c, 1 font $\$ 1.75$. mit céklarépát eltenni homokban, az ezt a fajt

\section{TARLÓ vagy KERÉK RÉPA}

TENYÉSZTÉSE: Nyári használatra vessük a magot kora tavasszal sorokba, 1-11/2 lábnyi távol. ságba helyezve el a sorokat. Öszi használatra vessük a magot julius vagy aügusztusban a fent leirt módon. Vagy pedig vethetjük általában elszórva a földön is.

KORAI FEHÉR KEREK. Korai lapos kerek fajta. A legszebb és legjobb evő-répák egyike. Adag 10c, ounce (1-16 font) 20c, 1/4 font 40 c, 1 font $\$ 1.25$.

SÁRGA GÖMB. Egyike a legjobb kerék vagy tarló répa fajoknak, amely ugy asztali használatra, mint állatok etetésére kitünönek bizonyult. Adag 10c, ounce (1-16 font) $20 c, 1 / 4$ font $40 c, 1$ font $\$ 1.25$.

VÖRÖS FEJƯ. A legmagasabb rendü fajok egyike, a husa ugy mint a külseje tiszta fehér, csak azon része vörös, amely a földböl kivül van. Kitünő ugy asztali használatra, mint állatok etetésére, asztali használatra akkor legjobb, amikor a répák 4 col átmérő göm. bölyüek, nagyon gyors növő és bőtermő. Adag 10c, ounce (1-16 font) 20 c, $1 / 4$ font 35 c, 1 font $\$ 1.25$.

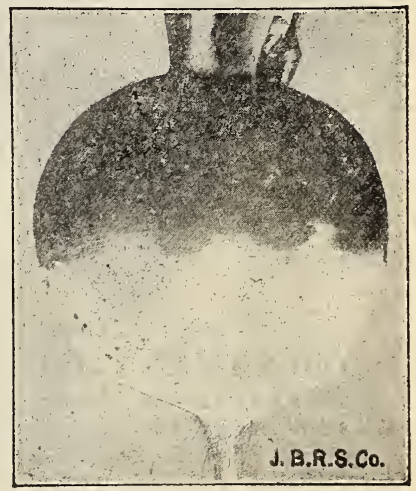

Vörös Fejü-Kerék Répa 


\section{HÓNAPOS RETEK.}

TENYÉSZTÉSE: Vessük a magot korán tavasszal ki a szabadba jól elkészitett, homokos földbe, egy láb távolságnyi sorokban. A növények kikeltével ritkitsuk meg a sorokban öket, miáltal fejlettebb retkeket nyerünk.

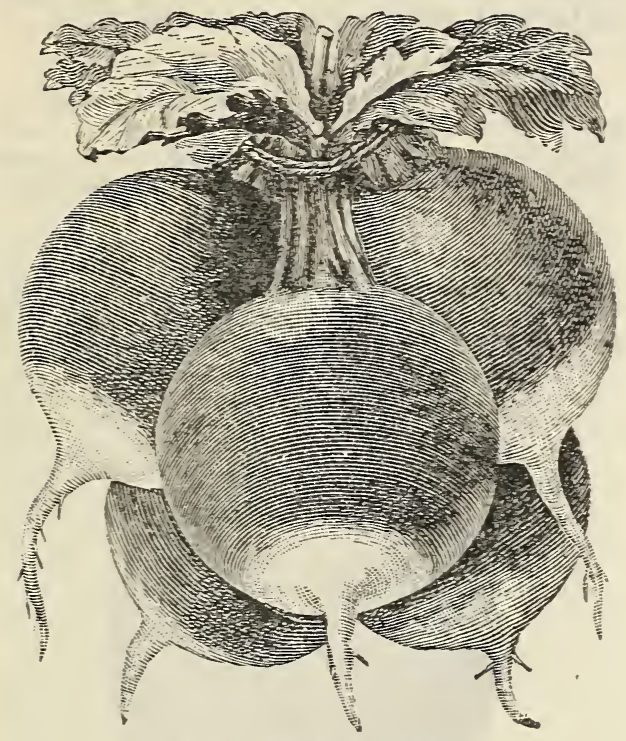

Korai Rózsapiros Retek

KORAI HÓGÖMB. Dacára annak, hogy melegágyi fajta, szabad földben is kitünően diszlik. Husa igen zsenge és jóizü. Adag 10c; ounce ( 1.16 font) $20 \mathrm{c} ; 1 / 4$ font $50 \mathrm{c} ; 1$ font $\$ 1.50$.

CINCINNATI PIACI. Finom izü, nagyon korai market faj. Hosszu, élénk piros gyümölcscsel, amely zsenge marad mindvégig. Adag 10c; ounce ( 1.16 font) $20 \mathrm{c}$; $1 / 4$ font $50 \mathrm{c} ; 1$ font $\$ 1.75$.

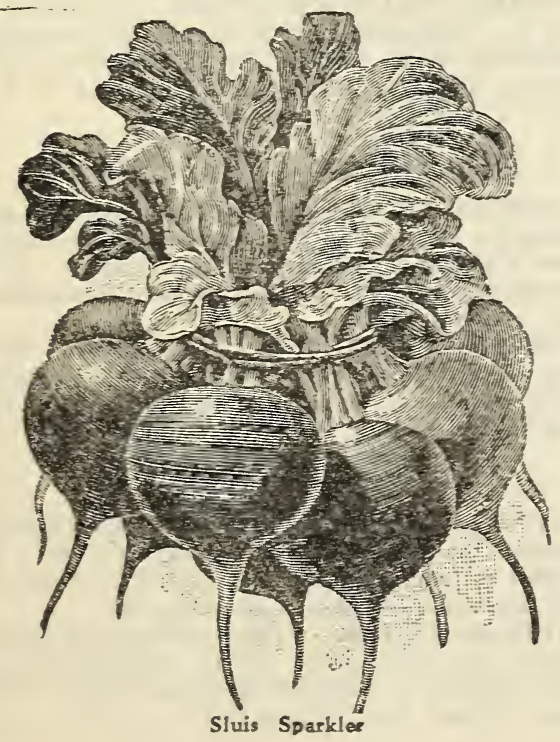

SLUIS SPARKLER. Dacára annak, hogy ezen uj faj vörös korai gömbölyü ertek, meleg ágyi fajta, szabadban is kitünően diszlik és a leg. nagyobb szárazságot kibirja. A retkek gömbö. lyüek és fénylő vörös szinūek, nagyon korai és teljesen pudva mentesek. Husa hófehér zsenge és édes, zsengeségét megtartja, mig a gyümölcsei teljesen ki nem fejlödnek és a magot lehet vetni, mihelyt a fagy kimegy a földből. A piaci termelök a legérrékesebb korai vörös reteknek tartják, üvegházi termelók meg csak teljesen ezen fajt használják. Családi kertek részére megbecsülhe. tetlen. Adag 15c; ounce ( 1.16 font) $30 c$; $1 / 4$ font $75 \mathrm{c} ; 1$ font $\$ 2.50$.

KORAI RÓZSAPIROS. Ezen szép hónapos retek korai fejlődése bámulatos, amennyiben alig 20-25 nap alatt teljesen kifejlödik. Gyümölcse gömbölyü, felül remek rózsapiros, mig az alsó fe. le hófehér. A legjobb és legizletesebb faj asztali használatra. Nagyban keresett piaci fajta. Adag $10 c$; ounce ( 1.16 font) $20 c$; $1 / 4$ font $50 c$; 1 font $\$ 1.75$.

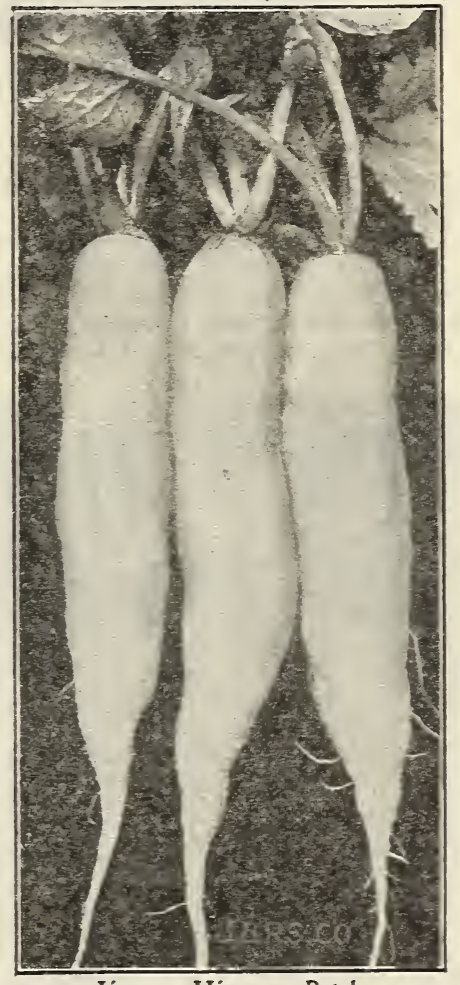

Jégcsap Hónapos Retek

JÉGCSAP RETEK. A fehér jégcsap retek a legremekebb retek az összes fehér fajok között. 30 nap alatt teljesen kifejlödik 4-5 col hosszura és a jégcsap alaku gyümölcsei fenséges jó izüek, tovább megtartja zsengeségét és remek izét, mint az összes retek fajok. A jégcsap retek nem csak, hogy jó izü, hanem kitünően fest a piacokon, a gumók egyenesek és simák, nagyon kevés az oldal. gyökér, megmosva és össze kötözve csomókban a piacokon kapósabb, mint az összes többi fajok. Adag 10c; ounce (1-16 font) $20 c$; $1 / 4$ font $50 c$; 1 font $\$ 1.75$. 


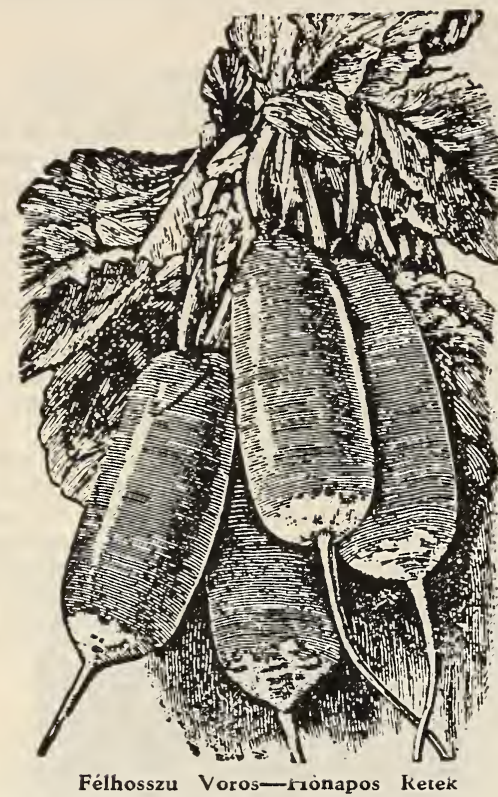

FÉLHOSSZU VöRöS. Igen gyönyörü Olive alaku, gyorsan fejlödö retek faj, szine rózsaszin, alsó részük pedig átlátszó jégfehérré változnak. Husa teljesen fehér és nagyon édes, 25 napra a mag vetése után használható. Ugy üvegházi, mint kerti vetésre kitünő. Adag $10 \mathrm{c}$; ounce (1-16 font) $20 \mathrm{c} ; 1 / 4$ font $50 \mathrm{c} ; 1$ font $\$ 1.50$.

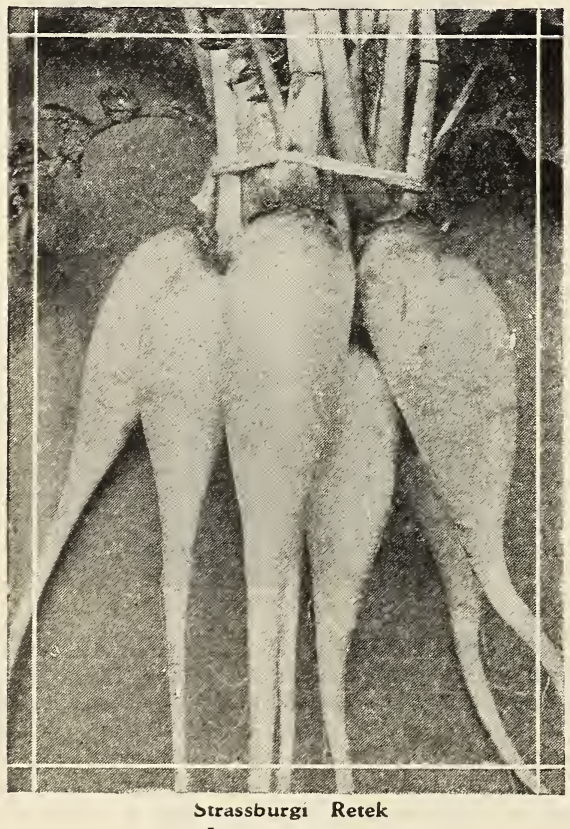

NYÁRI RETEK.

STRASSBURGI. Ezen nagy fehér faj retek a legjobb az összes nyári fajok között. Gyümölcsei kifejlődnek 4-5 col hosszu és 2 col átmérö nagy. ságra, husa teljesen fehér és zsenge, nagyon édes, alakja tojásdad. A nyári retek fajt vessük május elsején és az után minden 10 napra, aug. 15-ig. Adag 10c; ounce (1-16 font) $20 \mathrm{c}$; $1 / 4$ font $50 \mathrm{c}$; 1 font $\$ 1.50$.

KALIFORNIAI FEHÉR. Tiszta fehér. Kitünö tápláló faj, hófehér hussal. Adag $10 \mathrm{c}$; ounce (1-16 font) $20 c ; 1 / 4$ font $50 c ; 1$ font $\$ 1.75$.

\section{ÖSZI RETEK.}

KINAI VIOLAPIROS. Kitünő minőségü, őszi retekfaj. Gyümölcsének külső szine violapiros, husa pedig hófehér. Adag 10c; ounce (1-16 font) $20 c ; 1 / 4$ font $50 c ; 1$ font $\$ 1.50$.

\section{TÉLI RETEK.}

TENYÉSZTÉSE: Augusztusban vetendő 11/2 -2 láb távolságbani sorokban. Midőn a mag kikelt és a növények megerösödtek, ki kell ritkitani azokat 3-4 hüvelyk távolságnyira.

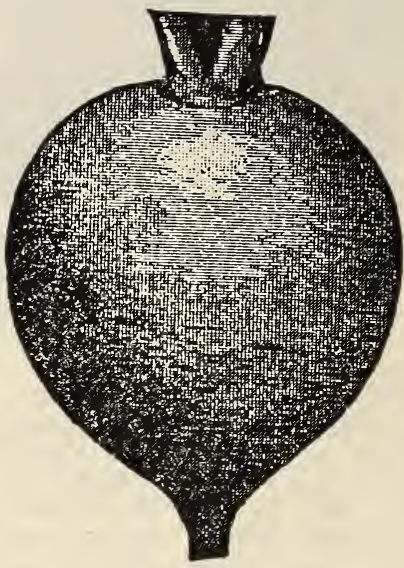

Fekete Téli Spanyol Retek

KEREK FEKETE SPANYOL. A legjobb télálló faj. Gömbölyü gyümölcsei szép nagyok, a melyeknek külső szine sima, koromfekete, remek hófehér hussal. Adag 10c; ounce (1-16 font) 25 c; $1 / 4$ font 50 c; 1 font $\$ 2.00$.

\section{RABARBARA (Páj Palánta.)}

VETÉSE: A mag májusban vagy juniusban vetendő a kertnek egy oly részébe, ahol állandóan, mint a sóska, vagy spárga, megmaradhat. A reá következő évben a levélszárak már használhatók pie (páj) készitésére.

ÓRIÁS LEVELƯ PÁJ PALÁNTA. Óriási nagy levélszárakat hozó faj, amelyek a legfino. mabb savanykás izüek. Adag 10c; ounce (1-16 font) $20 \mathrm{c} ; 1 / 4$ font $60 \mathrm{c} ; 1$ font $\$ 1.75$.

\section{SPÁRGA.}

TENYÉSZTÉSE: Vessük a magot tavasszal 12 hüvelyk távolságu sorokba és hagyjuk ott a gyö. kereket jól megerősödni, - legalább 2 évig, amidőn kiültethetjük öket a spárgaágyba.

ÓRIÁSI FEHÉR. A legkorábbi és a legkellemesebb izü, általánosan ismert market faj. Na. gyon bötermő. Adag 10c; ounce (1.16 font) $25 c ; 1 / 4$ font 50 c; 1 font $\$ 1.75$. 


\section{SPENÓT vagy LABODA.}

TENYÉSZTÉSE: A mag áprilisban vetendő, vagy mihelyt az idő alkalmas arra. A spenót magot egy láb távolságra fekvő sorokba vetjük, jól trágyázott földbe.

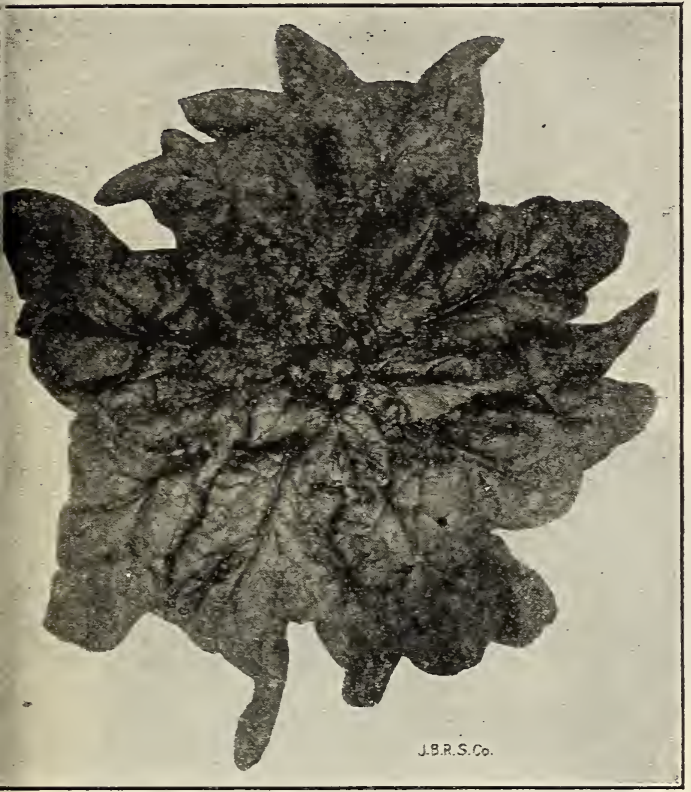

Dán Király

DÁN KIRÁLY. Igen nagy levelü, alacsony növő, lapos bokru uj spenót faj. Levelei hosz. szuak és szélesek és nagyon vastag husuak. Levelei sötét zöld szinüek, melyeket hosszu szárakon hoz és kitünő izü. A legjobb tulajdonsága ezen spenót fajnak az, hogy teljes egy hónappal to. vább lehet levelezni, mint a többi fajokat, mielött felmagzanak és a legkorábbi az összes spenót fajok között. Piaci termelők holdszám termelik, ugy piacra, mint a befőző gyáraknak. Házi használatra nagyon gazdaságos és kitünő eledelt szolgál. Adag 15c; ounce (1-16 font) $30 \mathrm{c}$; $1 / 4$ font $75 \mathrm{c} ; 1$ font $\$ 2.25$.

VIKTÓRIA. Sötétzöld, nagy vastag, husos levelekkel. Későn magzik, ennélfogva a legjobb faj házikertek részére és piaci eladásra. Adag 10c; ounce (1-16 font) $20 \mathrm{c} ; 1 / 4$ font $50 \mathrm{c} ; 1$ font $\$ 1.50$.

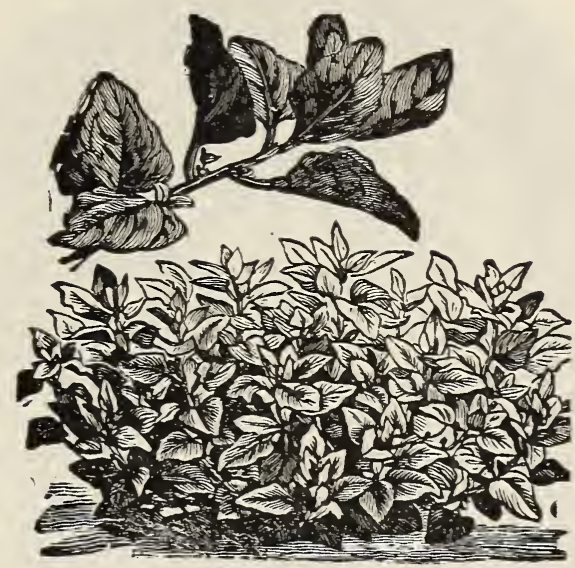

Uj-Zeeland Spenót

\section{UJ ZEELAND SPENÓT.}

UJ ZEELAND. Ezen spenót ujdonság a magyar honfitársak között még ismeretlen, de ha bárki is egyszer megismeri, többé a kertje nem lesz ezen kitünő faj spenót nélkül. Ezen faj nem emelkedik föl, inkább futó növény, egy palánta 3-4 lábra kiterjed a földön. Rengeteg le. véltermést ad, mennél gyakrabban levelezik, annál gyorsabban nö, gömbölyü, husos levelei egész a fagy beálltáig használhatók, mert zsenge és nem magzik föl. Adag 10c; ounce (1.16 font) 30c; $1 / 4$ font $60 \mathrm{c} ; 1$ font $\$ 1.75$.

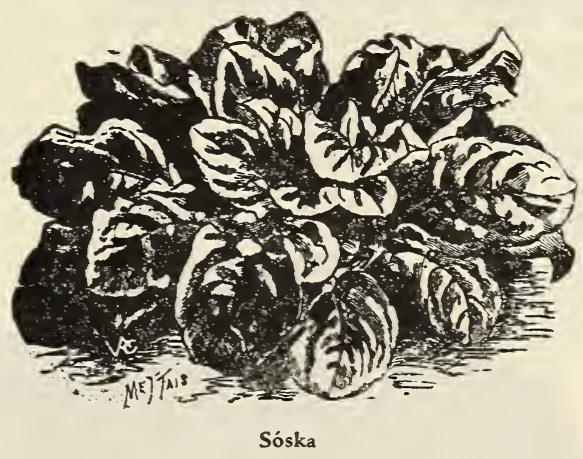

SÓSKA.

TENYÉSZTÉSE: Megterem bármely talajban és rendesen a kertnek oly részébe vessük a magot, ahol évekig elállhat. A mag kora tavasszal elve. tendő egy láb távolságnyi sorokban.

NAGY LEVELÜ. Igen nagy, vastag és finom, zsenge levelü. Kora tavasztól késô őszig szedhető. Adag 10c; unce (1.16 font) $50 c$; $1 / 4$ font $\$ 2.00$. 


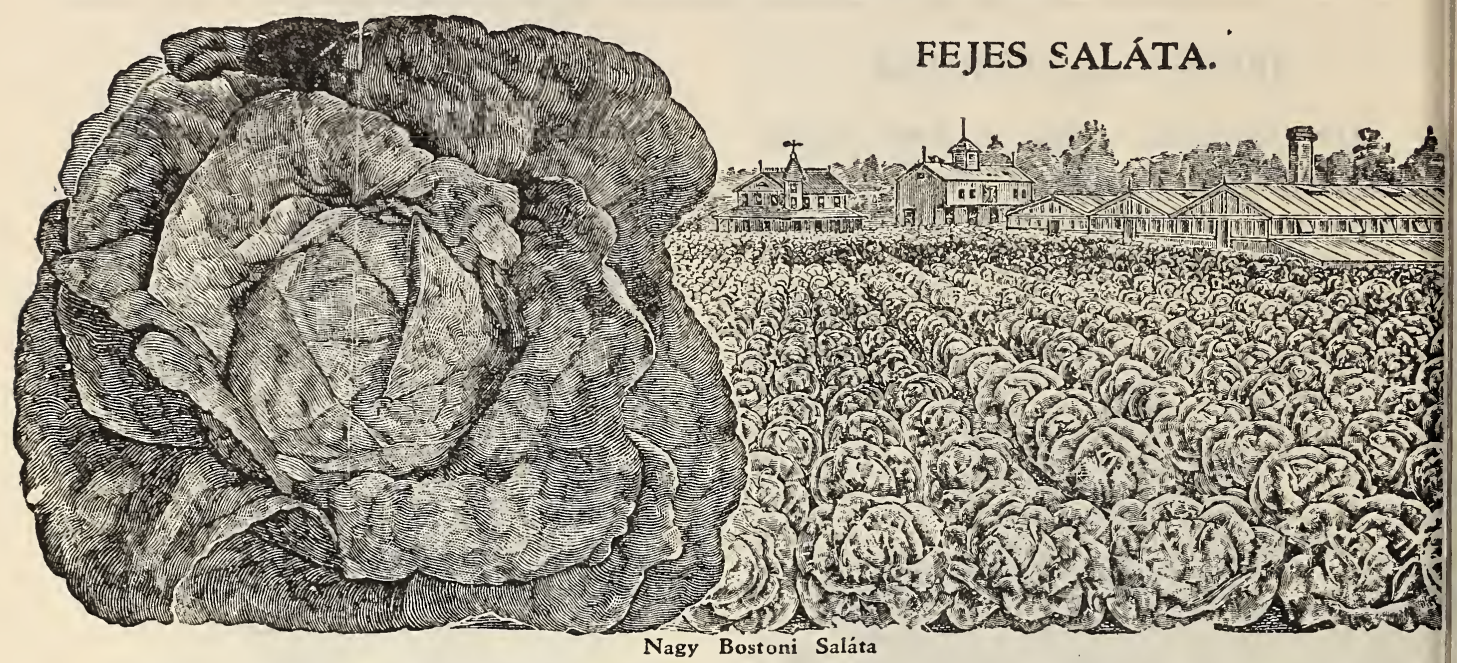

NAGY BOSTONI. Az általánosan termelt legjövedelmezőbb market-saláta. Nagy kemény fejü, sima zöld levelekkel. Egyike a legszebb és legtökéletesebb fajtáknak. A szorosan egymáshoz fekvő sima levelek szép világos-sárga szinüek. Adag 10c; ounce (1-16 font) 30c; $1 / 4$ font $75 \mathrm{c}$; font $\$ 2.50$.

"CALIFORNIAI ÓRIÁS" FEJES SA LÁTA. A legjobb korai fejes saláta, olvan kemény, mint a káposztafej. Levelei kissé fodrosak, szép fehérzöldek és zsengeség tekintetében egy fajta sem mulja felül. Sokkal előbb fejesül, mint más fajta. Adag 10c; ounce (1-16 font) $40 \mathrm{c} ; 1 / 4$ font $\$ 1.00 ; 1$ font $\$ 2.50$.

GRAND RAPIDS. Ezen saláta a legismertebb a zöldség termelők és a vevő közönség között, majdnem teljesen csak ezen fajt tenyésztik télen üveghá. zakban. Szabadbani kora tavaszi és őszi tenyésztésre a legkitünőbb faj. Nagy laza fejeket fejleszt, szine világos zöld, kissé fodros és nagyon zsenge, vetés után 5 hétre már ugy kifejlödik, hogy használni lehet. Adag 10c; ounce (1-16 font) $40 \mathrm{c} ; 1 / 4$ font $75 \mathrm{c} ; 1$ font $\$ 2.50$.

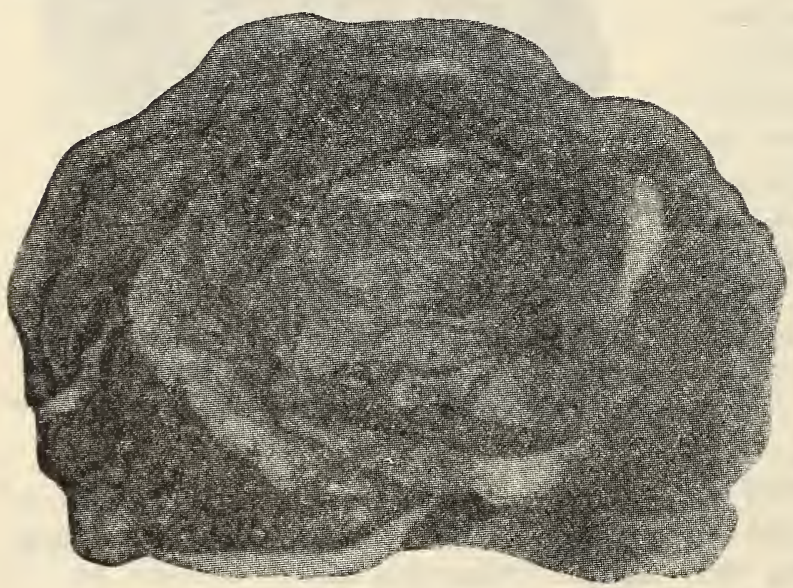

Los Angeles

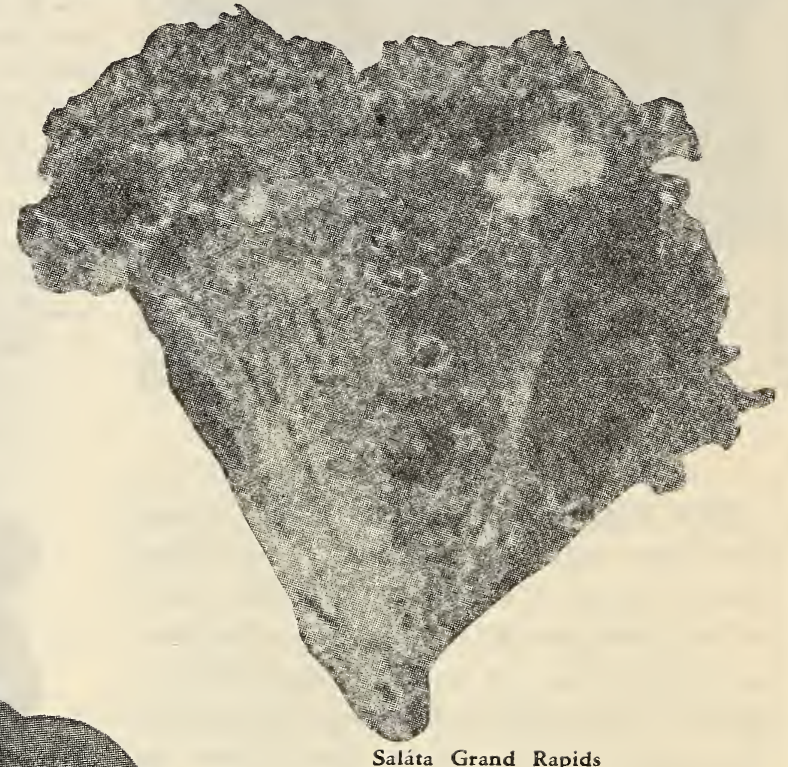

LOS ANGELES PIACI SALÁTA. Bármely éghajlaton kitünően tenyészik és óriási káposzta nagyságra kifejlődik, fejek átmérője néha 12-15 hüvelyk és elnyom 2-3 fontot. A külső levelek szorosan tapadnak a fejhez, melyek haragos zöldek, mig a fej közepe gyönyörü sárgás-fehér, fenséges zsenge és ropogós. Ezen fajt nagyban tenyésztik Los Angeles körül és ideszállitják az északi váro. sokba, mert kemény fejénél fogva he tekig is birja a szállitást. Tavaszon épp ugy, mint nyáron és őszön, lehet plán. tálni, mert ez nem magzik fel. 1 adag $15 \mathrm{c}$; ounce ( $1-16$ font) $55 \mathrm{c}$; $1 / 4$ font $\$ 2.00$. 


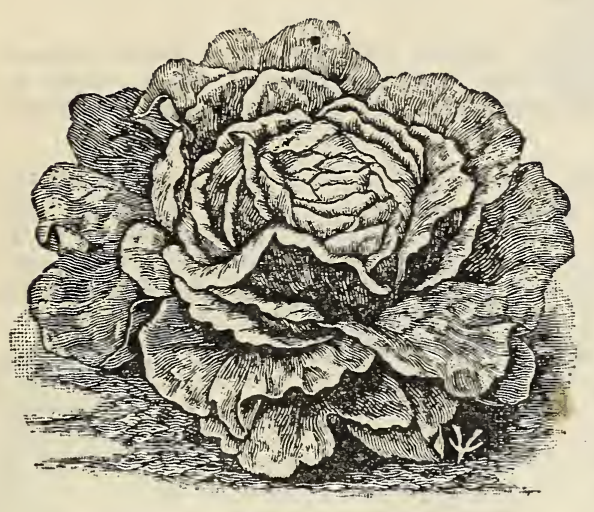

Május Király-Saláta

DENVER PIACI. Nagy, pompás, sárgazöld, káposztanagyságu fejeket fejleszt. Ugy korai, mint késői termelésre kiválóan alkalmas. Levélzete nehéz, zsenge és fodiros. Adag 10c; ounce (1-16 font) $30 c$; $1 / 4$ font $65 \mathrm{c} ; 1$ font $\$ 2.25$.

NYÁRI VASFEJÜ. Rendkivül zsenge fejeket fejlesztő saláta faj. Külső levélzete zöld, belül sárga. A fejek gyorsan fejlödnek és kemények. Adag 10c; ounce (1-16 font) $30 c ; 1 / 4$ font $65 c ; 1$ font $\$ 2.25$.

MÁJUS KIRÁLY. Különösen becses korai saláta faj. Kora tavaszi vetésnél kint a szabadban, a fejek hamarosan kifejlődnek $6-7$ col nagyságra:- Külső levelei világos zöldek, amelyek szorosan tapadnak a fej. hez, belső levelei aranysárgák és nagyon zsengék, vaj izüek. Kitünő ugy piaci termelésre, mint házi haszná. latra. Adag 10c; ounce ( $1-16$ font) $40 \mathrm{c}$; $1 / 4$ font $75 \mathrm{c}$; 1 font $\$ 2.50$.

\section{TÉPNI VALÓ SALÁTA.}

KORAI DIJNYERŐ. Rövid idő alatt fejleszt nagy mennyiségü vörös-barna, zsenge, fodros leveleket, amelyek kitünő zsenge salátát szolgáltatnak. Alkalmas minden évszakban való termelésre is. Korai használatra a magot ágyba sürün vessük és mihelyt a palánták fölemelkednek 3-4 hüvelyk magasra, már lehet tépni és használni is, melyért nyerte a tépni való saláta nevet. Adag 10c; ounce (1-16 font) $40 c ; 1 / 4$ font $75 c ; 1$ font $\$ 2.50$.

\section{TÉLI SALÁTA.}

TENYÉSZTÉSE: A magot augusztus hó végétõl szeptember hó közepéig vetik $s$ a megerösödött növényeket október hóban szétültetik állandó helyükre. Télire falevél vagy szalmástrágya takarót kiván. Tavaszon szép fejes salátát szolgáltat.

TÉLI VASFEJ. Teljesen télálló és gyenge sárga fe. jeket hozó téli saláta faj. Adag 10c; ounce (1-16 fon) 40 ; $1 / 4$ font 75 c; 1 font $\$ 2.50$.

BARNA TÉLI. Rendkivül ellentállóképes, vérpiros levélzetü saláta faj. Adag 10c; ounce (1-16 font) 40c; $1 / 4$ font $75 \mathrm{c} ; 1$ font $\$ 2.50$.
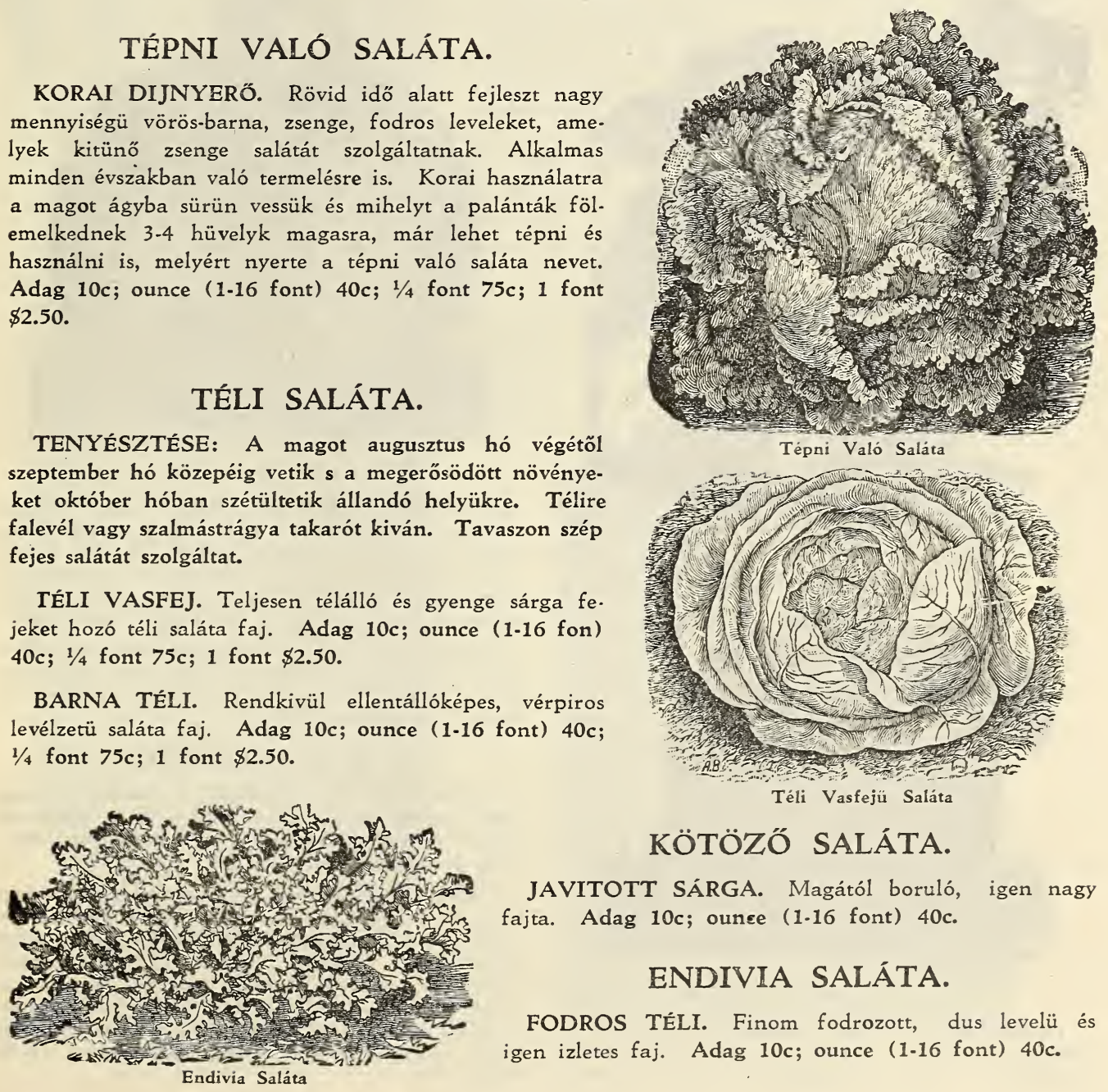

\section{KÖTÖZÓ SALÁTA.}

JAVITOTT SÁRGA. Magától boruló, igen nagy fajta. Adag 10c; ounce (1.16 font) 40c.

\section{ENDIVIA SALÁTA.}

FODROS TÉLI. Finom fodrozott, dus levelü és igen izletes faj. Adag 10c; ounce (1-16 font) 40c. 


\section{TÖK FAJOK.}

TENYÉSZTÉSE: A spárga és sütô tök fajok tenyésztése nagyon egyszerü, a magvak elveten. dők április végén vagy májusban halmokba és fészkekbe, egy-egy halomba tehetünk 6-8 magot és mikor már a növények teljesen mentesek a rovarok tól, meghagyhatunk 3-4 növényt egy halomban. Általában könnÿ̈, jól megmüvelt földet igényel.

ZÖLD SPÁRGA-TÖK. Hosszu zöld, bőven és szaporán terem, zsenge, hófehér, a legfinomabb főzeléket szolgáltatja. Adag 15c; ounce (1-16 font) $35 c ; 1 / 4$ font $75 c ; 1$ font $\$ 2.25$.

FEHÉR SPÁRGA-TÖK. Fehér, hosszu indátlan, vagy guggon ülö, vastag husa izletes főzeléket ad. Általánosan ismert piaci faj. Adag 15c; ounce (1-16 font) $35 c$; $1 / 4$ font $80 c ; 1$ font $\$ 2.50$.

NAGY SÁRGA. Közönséges mezei tök, vagy disznótök. Roppant bőven terem és zöld korában zsenge husa kitünő fözeléket is szolgáltat. Adag 10c; ounce (1.16 font) 25c; $1 / 4$ font $45 c$; 1 font $\$ 1.50$.

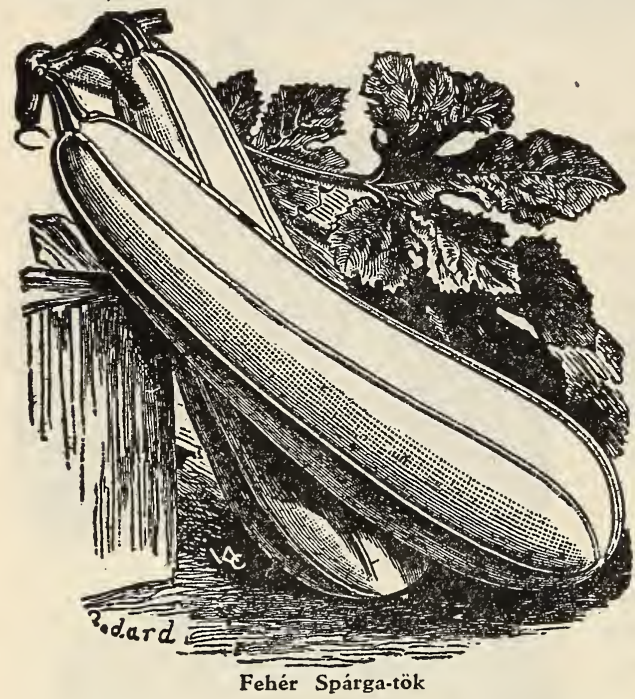

b) Sütő-tök fajok.

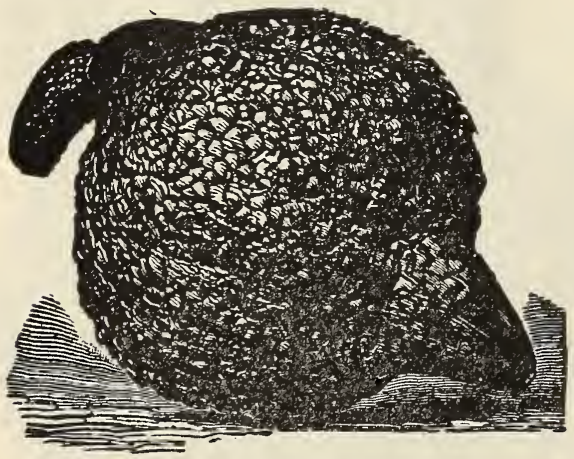

Hubbard-Sütö-tök

HUBBARD. A legfinomabb sütő tök az öszszes fajok között. A piaci termelők a sütő tökök királyának nevezik, a nagybani kannázó gyárak részére a termelök teljesen csak ezt használják. Eláll egész télen és mennél tovább áll, annál jobb izü. Szine sötét zöld és göcsörtös kemény héju, husa kitünő, ugy házi használatra, mint piaci termelésre felülmulhatatlan. Adag 10c; ounce (1-16 font) $25 c ; 1 / 4$ font $75 c ; 1$ font $\$ 2.50$.

ARANY HUBBARD. Ezen faj épp az, ami a Hubbard, csak ennek a héja sárga és nem fejlödik ki oly nagyra, mint a Hubbard, minősége épp az, ami a Hubbardé. Teljesen télálló, a leg. jobb téli fajok egyike. Adag 10c; ounce (1-16 font) $25 \mathrm{c}$; $1 / 4$ font $75 \mathrm{c} ; 1$ font $\$ 2.50$.

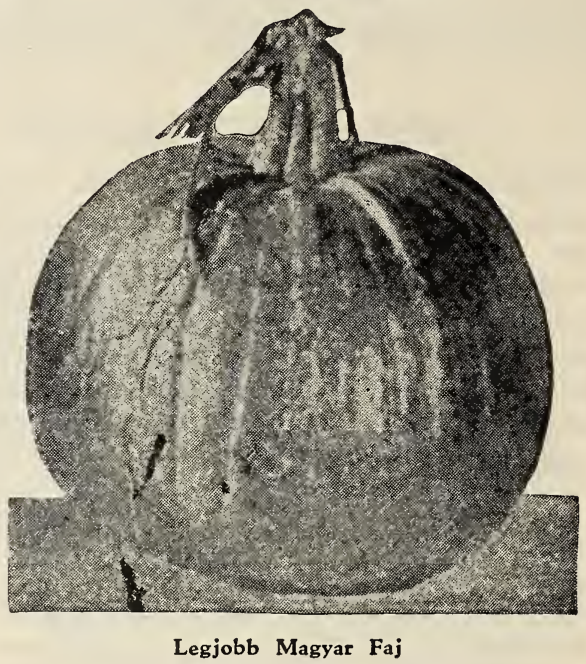

LEGJOBB MAGYAR FAJ. Ezüst szürke, gömbölyü magyar faj. Héja kissé kemény, husa narancs-sárga és kitünő izletes. Egyike a leg. jobb gömbölyü faj sütő tököknek és nagyon so. káig elálló, ugy sütni, mint pájra kitünő eledel. Adag 10c; ounce (1-16 font) 60c; 1 font $\$ 2.00$.

MAMMUTH. Igen nagy, gyakran nagy sulyt is elér, takarmányozási célra alkalmas, igen bố. termő. Adag 10c; ounce (1-16 font) 25c; $1 / 4$ font $75 c ; 1$ font $\$ 2.00$.

\section{TOJÁS-GYÜMÖLCS.}

TENYÉSZTÉSE: Vessük a magot március vagy április hóban melegágyba és a növények megerősödtével ültessük ki öket a szabadba; könynyï, gazdag talajba.

FEKETE GYÖNGY. A legkorábbi és a legjobb az összes tojás gyümölcs fajok között. A nagy gyümölcsei vastagok és kitünö izüek, szine kékes-fekete. Nagyon bötermő és 10 nappal elöbb érik, mint akármelyik más faj és nem is kivánja az elsörendü munkált földet, mint a többi fajok. Piacokon nagyon kapós, házi használatra pedig csemege. Adag 10c; ounce (1-16 font) $75 c$. 


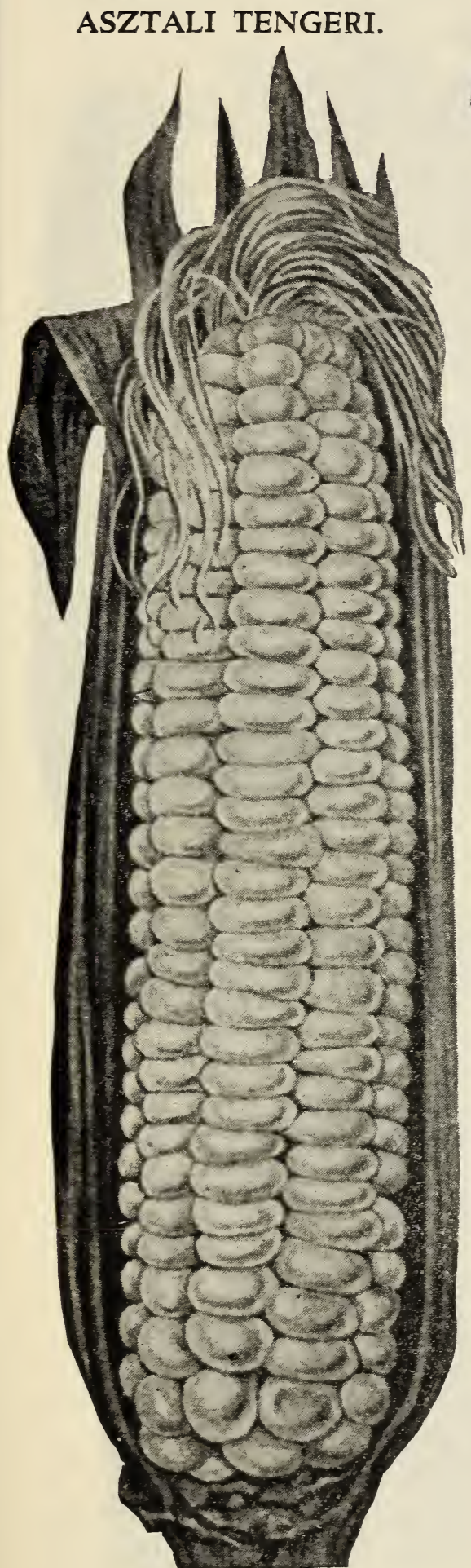

Korai Cukor Tengeri

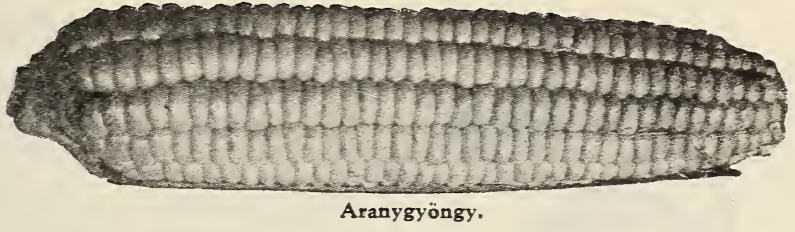

KORAI ARANYGYÖNGY. Bármi is annak az oka, de azt mindnyájan tudjuk, hogy ezen faj édes tengeri a legjob. ban használt az összes tengerik vagy kukoricák között. A leg. korábbi fenséges izü édes tengeri faj, szine aranysárga, szemei a csutkán tömve teltek, amelyek a legkellemesebb izt szolgálják, csövei 8 sorosak és 7.8 inch hosszuak, a legjobb nagyságu asztali használatra. Szárának növése alacsony és roppant bötermő, a legkorábbi és a legédesebb asztali ten. geri a piacon. Adag 15c; 1 font $45 c ; 2$ font 90c. Expressen 10 font $\$ 3.50$.

KORAI FEKETE. Fekete szemü, de főzés alkalmával egé. szen megfehéredik, csövei 8 inch hosszuak és tömve vannak mézédes szemekkel, amelyek kissé laposak, nagyon bőtermô és kitünő asztali csemege. Adag 10c; 1 font $40 c ; 2$ font $75 c$. Expressen 10 font $\$ 3.00$.

KORAI CUKOR TENGERI. Ezen fehér szemü, 12 soros édes tengeri a legkorábbi a fehér szemü fajok között. A csövek kifejlödnek 9-10 inch hosszura és fehér szemei felséges édesek. A legjobb és a legbőtermőbb a korai fehér fajok között. Ugy piaci, mint házi használatra felülmulja az összes fajokat. Adag 15c; 1 font $45 c ; 2$ font 80c. Ex. pressen 10 font $\$ 3.50$.

FEHÉR GYÖNGYSZEMÜ. A legfinomabb kései tengeri amit csak valaha termeltek, a csövei nagyok és édesek, a szemek fénylö fehérek és rengeteg bőtermő, minden száron 3.4 csövet fejleszt, amelyek mézédességü szemekkel meg van. nak rakva. A piaci termelők egyedül ezt használják késői fajnak és holdszám termelik a kannázó gyárak részére. Adag $15 c ; 1$ font $45 c ; 2$ font $80 c$. Expressen 10 font $\$ 3.50$. NEKTÁR. Egyike a legédesebb fajoknak. Csutkája igen vékony, szeme pedig nagy, fehér, mint a gyöngy és kitünó izü. Adag 10c; 1 font 45c; 2 font 80c. Expressen 10 font $\$ 3.50$.

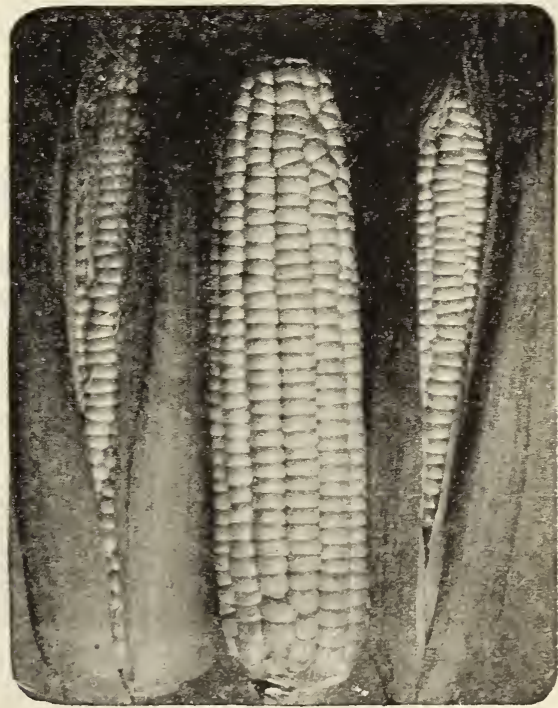

Fehér Gyöngyszemü 


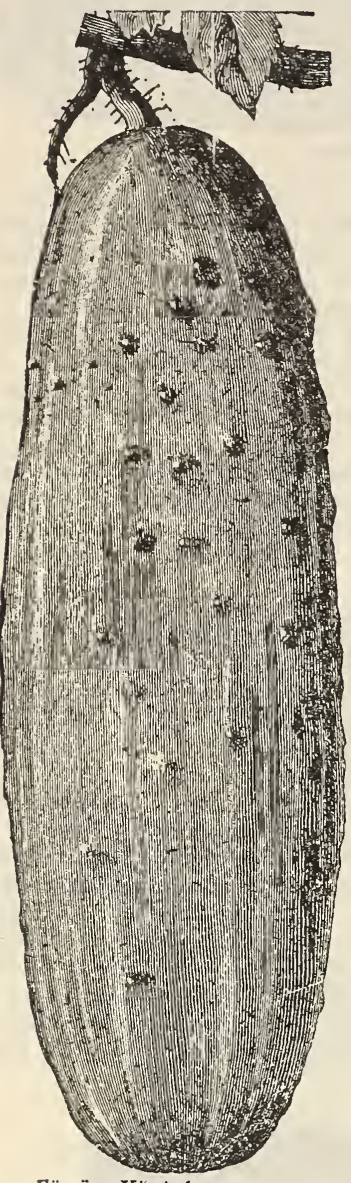

Fürtös Közèphosszu

\section{UGORKA FAJOK.}

TENYÉSZTÉSE: Az ugorka kényes kerti növény lévèn, várjuk meg az idö teljes fölmelegedését. A magot ültessük 3-4 láb távolságban felhuzott halmokban, vagy ugyanily tá volságban fekvő sorokba. Jól elkészitett, kissé nedves talajt kiván.

DAVIS PERFECT. Ezen ugorka ujdonság a legkorábbi és a legnagyobb az összes fajok között. A gyümölcsei kifejlődnek 9 col hosszuakra, szine sötétzöld és nagyon finom izü, husa nagyon kemény és ropogós, a mag cellák nagyon kicsik és kevés magot fejleszt, ennélfogva a legjobb ugorkasalátát szol gáltatja és besavanyitásra télire ecetben elsőrendü. A piaci termelök óriási nagyban termelik a piacokon oly gyönyörüen fest, hogy nagyobb árt hoz, mint akármelyik más faj. A növeny nagyon erös növő, bötermö és jobban birja a szárazságot, mint barmely faj. Házi használatra megbecsülhetetlen. Adag 15c; ounce ( 1.16 font) $35 \mathrm{c} ; 1 / 4$ font $90 \mathrm{c}, 1$ font $\$ 3.00$.

FÜRTÖS KöZÉPHOSSZU. Korai középhosszu, kiváló minösègü, a kurai ecetbeni savanyitásra a legfinomabb. Igen bő terınö gyümölcseit fürtökben hozza, 3-4 egy fürtben, a leg. jobb tulajdonsága az, hogy a szárazságot kitünően birja. Ug piaci termelésre, mint házi használatra kitünő faj. Adag 10c. ounce ( 1.16 font) $25 \mathrm{c}, 1 / 4$ font $75 \mathrm{c}, 1$ font $\$ 1.75$.

HOSSZU ZöLD. Nagyon ismert és kitünö faj. Gyümölcsei hosszuak és sötét zöldek, a kifejlödött gyümölcsei kitünö ugy ecetbeni, mint salátának és fiatalkorán leszedve, még az elsörendü sweet pickle-t szolgálja, nagyon bötermö és erös növő. Adag $10 \mathrm{c}$, ounce (1-16 font) $25 \mathrm{c}, 1 / 4$ font $75 \mathrm{c}, 1$ font $\$ 1.75$.

KLONDIKE. Korai kitünő izü és nagyon bőtermő, gyümölcsei kifejlödnek 7 col hosszuakra és $23 / 4$ col átméró vas tagságra, salátának nagyon alkalmas amerikai faj és kitünö botermóségével nagyon ajánlható market faj. Adag 10c, ounce $(1.16$ font $25 \mathrm{c}, 1 / 4$ font $75 \mathrm{c}, 1$ font $\$ 1.75$.

JAVITOTT ÓRIÁS FEHÉR. Nagyon korai és finom izü, nagyra növő, fehér tüskés faj. Finom salátát szolgáltat és egyszersmind kitünő kovászos ugorka. Bötermősége felülmulhatat lan. Adag. 10c, ounce (1-16 font) $25 c, 1 / 4$ font $75 c, 1$ font $\$ 1.75$.

UGORKA, MAGYAR, LEGJ JBB. Félhosszu, zöld, ropogós izü, finom faj. Besavanyitásra télire, ecetbe a legkitünöbb fajta. Igen bötermö. Házi kertek részére megbecsülhetetlen, a piacra termelönek pedig aranybánya. Virágzása korán kezdődik s minden virágból egy ugorka fejlödik. Adag 10c, ounce (1.16 font) $25 c, 1 / 4$ font $75 c, 1$ font $\$ 1.75$.

FOLYTONTERMÖ UGORKA. Ezen ugorka ujdonság a legkorábbi az összes fajok közt. Tulajdonsága pedig az, hogy nem csinál oly dus indákat, mint a többi ugorkafajok, de bö termösége sokkal nagyobb; ha a gyümölcsét folytonosan leszedjük, akkor szakadatlanul egész ôszig terem. Gyümölcse sötétzöld, 4-6 hüvelyk hosszuak, $1 \frac{1}{2}$ hüvelyk átmérőben. Egyike a legjobb fajoknak, télire ecetben való eltevésre. Adag 15c, ounce ( 1.16 font) $30 \mathrm{c}, 1 / 4$ font $80 \mathrm{c}, 1$ font $\$ 2.50$.

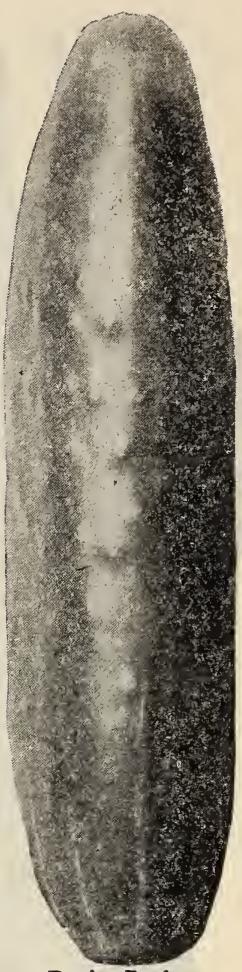

Davis Perfect

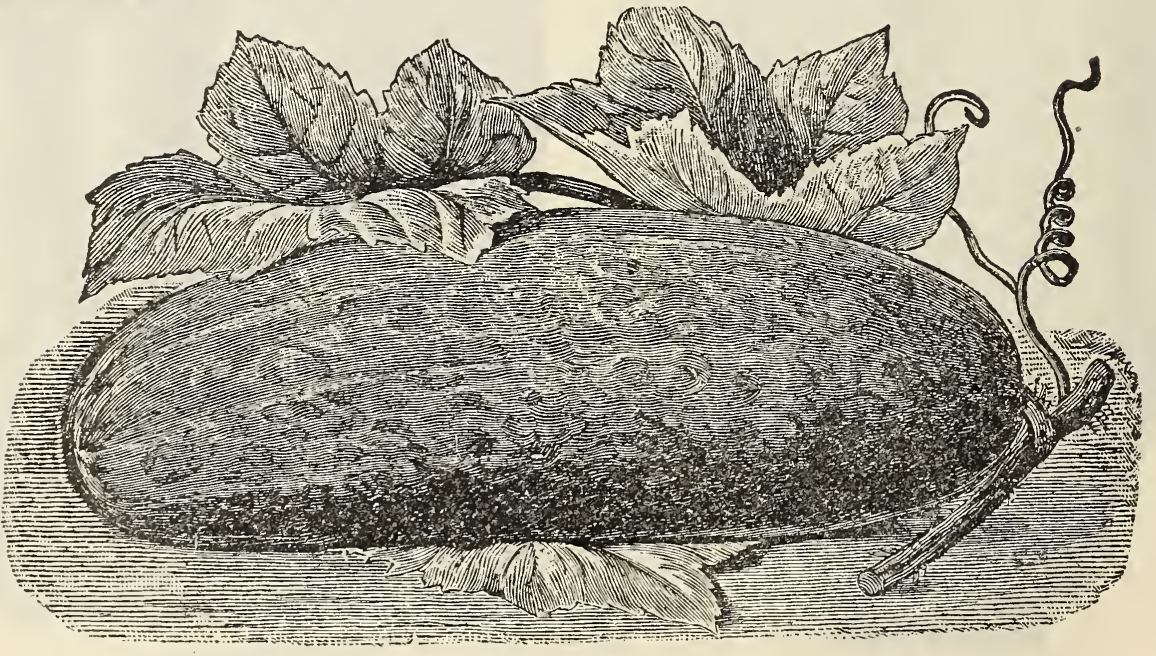

Klondike-Ugorka 


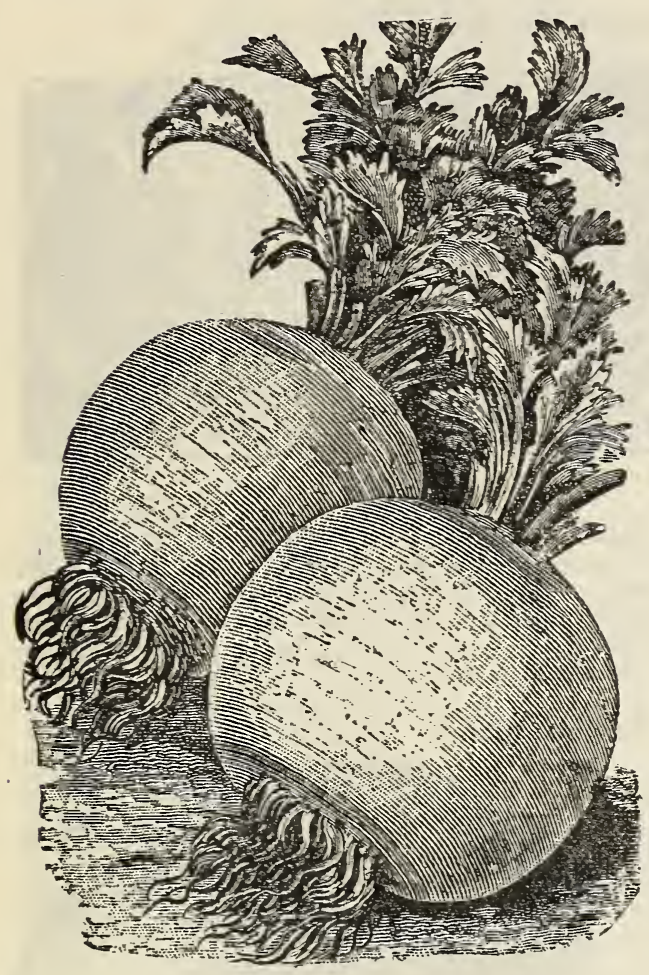

Prágai Óriás Zeller

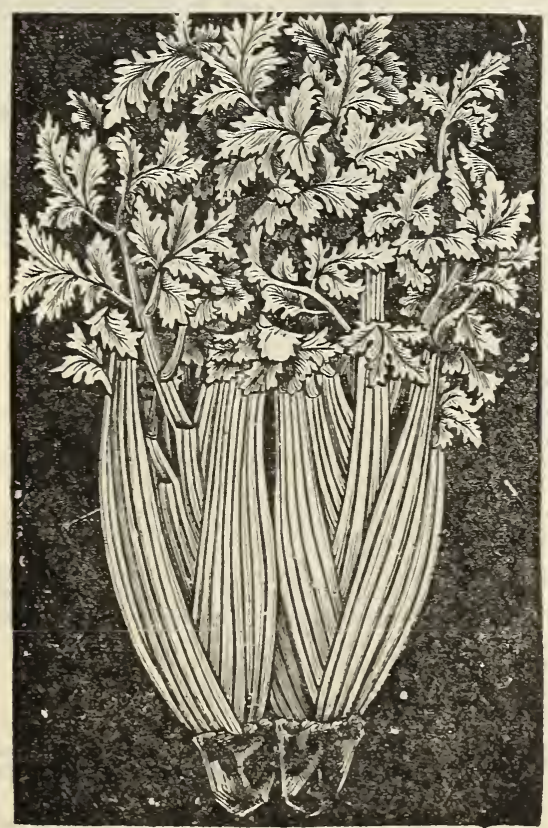

Korai Ószi-Szárzeller

\section{GUMÓS ZELLER.}

TENYÉSZTÉSE: Ha van alkalom, a mag melegágyba vagy ládába vetendő, amit világos, napos helyre helyezünk. Hagyjuk a növényeket jól megerösödni és azokat onnan, - ha már az idő alkalmas arra - a szabadba kiültetjük, fél láb távolságra egymástól. Kissé nedves, de jó ta. lajt kiván.

PRÁGAI ÓRIÁS. Kitünő fajta. Kevés gyökér mellett igen nagy, majdnem egész gömb. alaku gumókat fejleszt. Husa tiszta fehér és kitünő izü. A legkeresettebb és legjobb piaci fajta. Adag 10c; ounce ( 1.16 font) $50 \mathrm{c}$; $1 / 4$ font $\$ 1.50 ; 1$ font $\$ 5.00$.

\section{SZÁR- VAGY HALVÁNYITANDÓ ZELLER.}

TENYÉSZTÉSE: A szár vagy másképen halványitandó zeller épp ugy vetendö és kezelendő a kiültetésig, mint a gumós zeller. A sorokat a kiültetés után tartsuk tisztán, gyommentesen a nö. vényeket és idöközönkint felhuzzuk a földet, hogy a használandó szár minél zsengébb legyen.

ÓRIÁSI PASKÁL. Aranysárga szárai ropogósak és szálkamentesek, bevermelve tavaszig eltartható. Kitünó market faj. Adag 10c; ounce (1-16 font) $35 \mathrm{c} ; 1 / 4$ font $\$ 1.25$.

KORAI ÖSZI. Ezen fajta kora őszi használatra kétségtelenül a legfinomabb, aranysárga szine csábitó, szárai ropogósak, száikamentesek és a legjobb izüek. Adag 15c; ounce (1.16 font) $50 \mathrm{c} ; 1 / 4$ font $\$ 1.75$.

\section{VIRGINIA PEANUTS.}

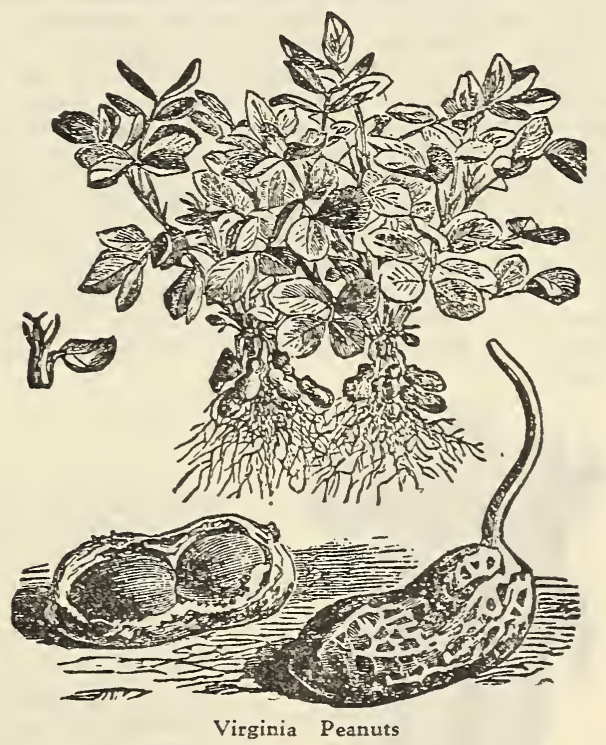

TENYÉSZTÉSE: A tenyésztése a burgonyáéhoz (krumpliéhoz) hasonló. A magot elültetjük halmokba és azok kikelte után a földet gondosan felhuzzuk körülötte idöközönkint.

VIRGINIA PEANUTS. A legjobb és legbő. termőbb faj, amelyet általánosan használnak ezen a vidéken. Adag 10c; 1 font $40 c$. 


\section{KERTI FÜSZER NÖVÉNYEK MAGVAI.}

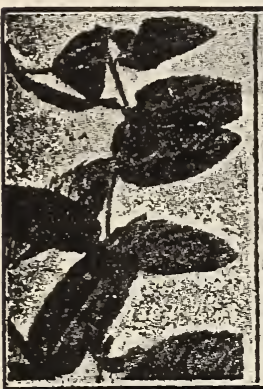

Bazalikum

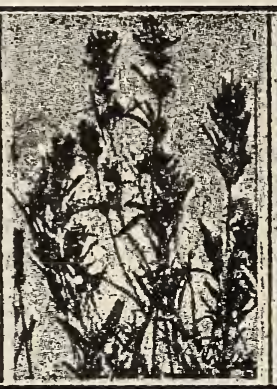

Borsfü

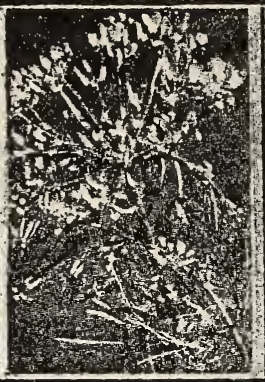

Ka por

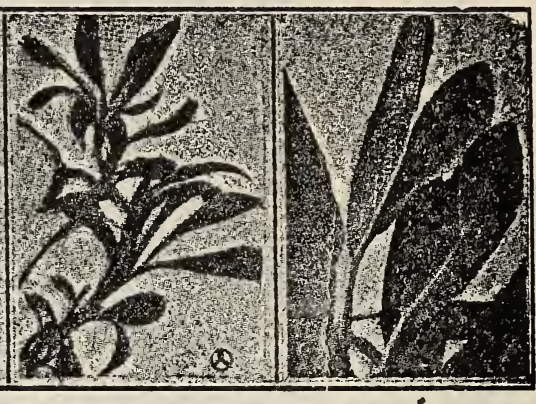

Levendula
Zsálya

Bazsalikum. Ocymum basalicum

Borsfü. Saturejt hortensis

Kakuk fü. Thymus vulgaris

$\begin{array}{ll}\text { Adag 10c } & \text { Kömény. Carum carui } \\ \text { Adag 10c } & \text { Levendula. Levendula spica }\end{array}$

Adag 10c

Adag 10c

Adag 10c

Majoránna. Origanum majoranna

Rozmaring. Rosmarinus officinalli........Adag 10c

Zsálya

Adag 10c

Adag 10c Tárkony

Sáfrány

\section{VEGYES GYÖKÉRFÉLÉK.}

\section{Gombacsira.}

CSIPERKE GOMBA TENYÉSZTÉSE. Legalkalmasabb helyek tenyésztésére istállók, pincék, üvegházak, rejtekhelyek, szabadban, stb. bárhol, ahol a hőmérsék nem kevesebb, mint 69 fok. Az ágy készitése a következőkép történik: Gyüjtsünk össze friss lótrágyát és ha már van elég, csináljunk bele hosszu halmot és azt öt napon át minden nap megforgassuk, az ötödik napon, amikor már a trágya eléggé átmelegedett, keverjünk közibe ugyan annyi mennyiségü jó földet, aztán helyezzük a trágyát oda, ahol a gombát tenyészteni akarjuk. És ott aztán akár a földön, akár valami deszka polcon, $16 \mathrm{col}$ vastagon erősen lepakoljuk, lepakolás után 3-4 napot várjunk, mire fölmelegszik és ekkor $1-2$ col mély lyukat vajjunk 12 col távolságban négyszögben és a lyukakba dió nagyságu gombacsirát helyezünk el és ekkor a lyukakat ismét betömjük és 1 col finoman rostált földet hintünk reá. Minden héten egyszer fölmelegitett esővizzel megöntözzük és az igy elkészitett gomba-ágy 6 hétre, 4-6 hétig szakadatlanul termi a szebbnél-szebb gombákat. A gombacsira préselve tégla alakban, egy tégely $13 / 4$ font, postán bérmentve, tégelyenkint darabja 40 cent. Expressen 5 tégely $\$ 1.75$.

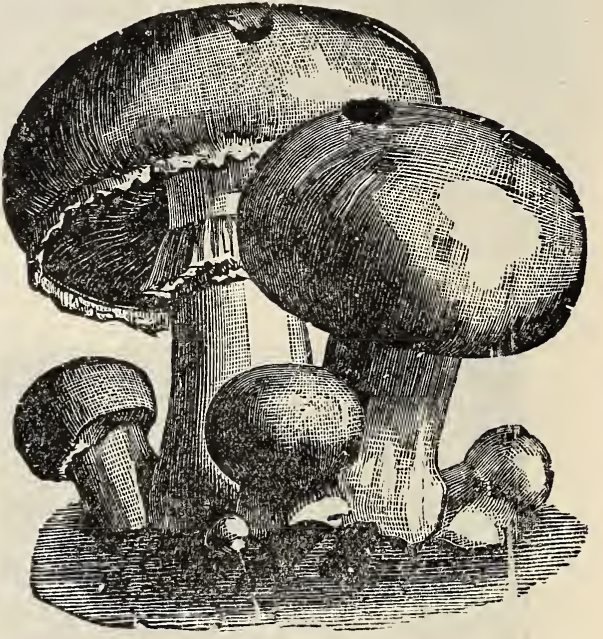

\section{TORMAGYÖKÉR.}

TENYÉSZTÉSE: A gyökerek a kertnek egy oly helyére ültetendők el, ahol évekig megmaradhatnak egy helyben. A gyökerek jó mélyre ültethetök.

KöZónSÉGES. Erötel jes gyökér dugványok. 10 darab 35c; 50 darab $\$ 1.00$. Expres. sen 100 darab $\$ 1.75$.

\section{RABARBARA GYÖKÉR vagy PÁJ PALÁNTA.}

TENYÉSZTESE: A rabarbara vagy az amerikai nép nyelvén ismert "pie plant". TENYESZTESE: A rabara vágya az ugynevezett rhubarb piet (pájt) szolgáltatjảh. amelynek zsenge bzárai darabokra vagva az ugynevezett rhubarb pió (pájétig szolgálnakd Az általunk kiküldött gyökerek agy

1 darab 25c; 10 darab $\$ 2.00$. Expressen 100 darab $\$ 15.00$. in:

\section{SPÁRGA GYÖKÉR.}

TENYÉSZTÉSE: Uiltessük a gyökeret egy és fél láb távolságbani sorokba oly mélyre,

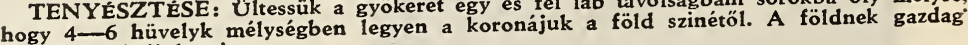
trágyásnak kell lenni.

ÓRIÁSI HóFEJ. Roppant nagy és vastag növéseket hozó faj. Remek izũ eledelt

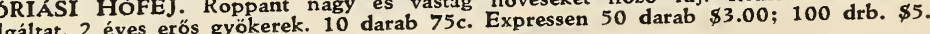




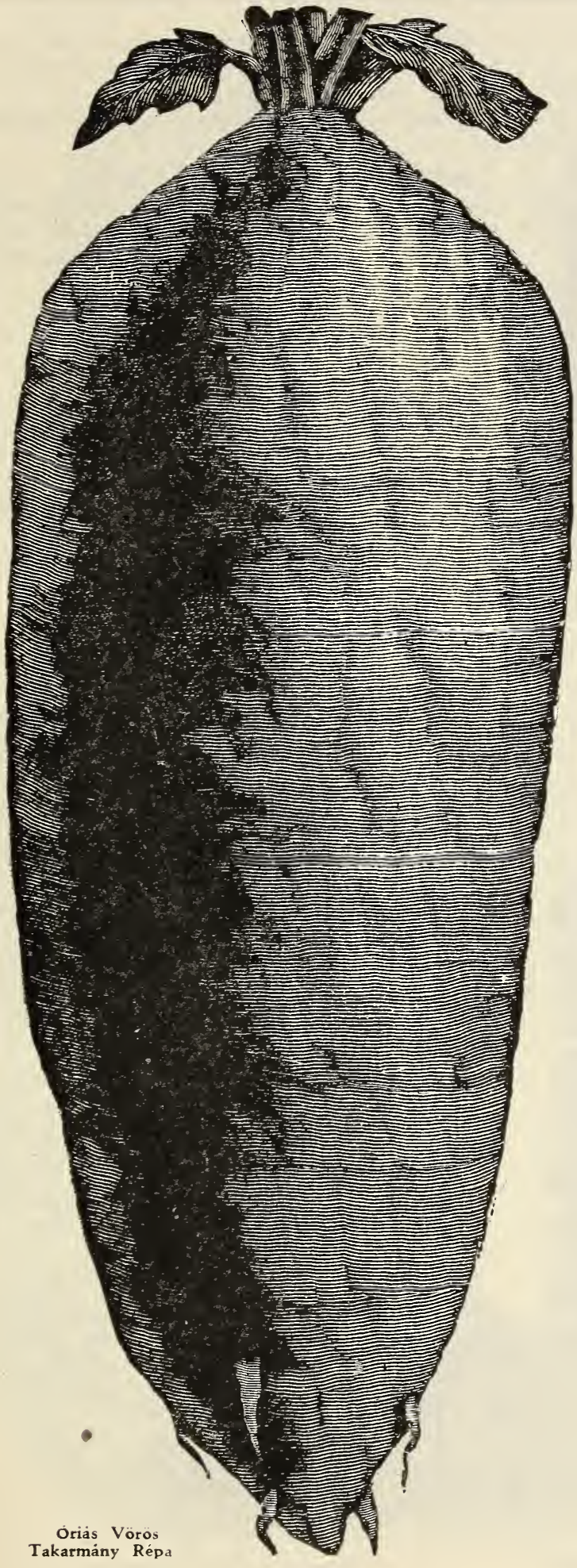

\section{GAZDASÁGI MAGVAK}

Az Egyesült Ảllamokban élő ma. gyar gazdák magvaiknak $1 \frac{1}{2}$ évtizedi használata a bizonysága, hogy a tölünk beszerzett gazdasági-, vető-, fü- és takarmány-magvak tul. haladják más cégek nagy hangon hirdetett cikkeit. Az alábbi jegyzékünk most is, mint eddig, csakis a legjobban bevált, Amerikaszerte tenyésztett gazdasági cikkek fajtái! foglalja magában.

\section{ÉSZAK-NÉMETORSZÁGI BURGUNDI TAKARMÁNYRÉPÁK.}

ÓRIÁS VÖRÖS. Óriási hosszu, husu takarmányrépa. Óriási pèldányokká fejlödik és példátlan nagy terméseket ad. Minden eszköz nélkül, puszta kézzel kiszedhető a föld böl. Bő tápanyag tartalma folytán tehenek és más állatok etetésére nagyon ajánlható. Adag 10c; ounce (1.16 font) $15 c ; 1 / 4$ font $30 c ; 1 / 2$ font $50 c ; 1$ font 70c. Expressen 10 font $\$ 6.00$.

ÓRIÁS SÁRGA. Az igazi Mauthner-féle sárga javitott Eckendorfi. Henger alaku, tompa végü, kicsiny gyökérrel, tömör husu. Északi vidékekre, agyagos talajra nagyon ajánlható. Ép ugy, mint az elöbbi, puszta kézzel kiszedhetö a földböl. Adag $10 c$, ounce ( 1.16 font) $15 c ; 1 / 4$ font 30 c; $1 / 2$ font 50 c; 1 font 70 c. Ex. pressen 10 font $\$ 6.00$.

Szállitási szabályainkat árjegyzékünk 2-ik oldalán találhatja. 


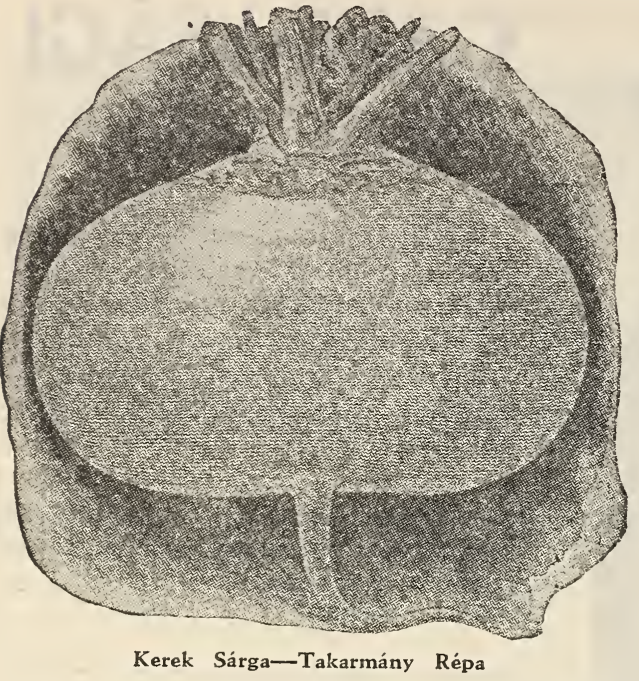

KEREK SÁRGA. Aranysárga szinü, kissé ová lis alaku takarmány répa, amely felette jövedelme zö faj. Adag 10c; ounce (1.16 font) 15c; $1 / 4$ font 30c; 1 font 70c. Expresszen 10 font $\$ 7.00$.

KEREK VÖRÖS. Alakja, bőtermősége meg. egyezik az elöbbivel, csak szinre különbözik tóle. Mig az előbbi sárga, ez vörös szinü. Adag 10c: ounce ( $1-16$ font) $15 c ; 1 / 4$ font $30 c ; 1$ font $70 c$. Expresszen 10 font $\$ 6.00$.

\section{CUKORRÉPÁK.}

JAVITOTT WILMORIN-FÉLE. Rengeteg nagv cukọrtartalmu gumókat fejleszt. A legtöbb répa. talajban beválik $s$ ezért ajánlható. Adag 10e; ounce ( $1-16$ font) $15 \mathrm{c} ; 1 / 4$ font $25 \mathrm{c} ; 1$ font $60 \mathrm{c}$. Expresszen 10 font $\$ 5.00$.

\section{MEZEI TENGERI (Kukorica).}

Törvényesen 56 font tengeri vagy kukorica van egy bushliban. Nagyban való termelésre alkalmas fajták.

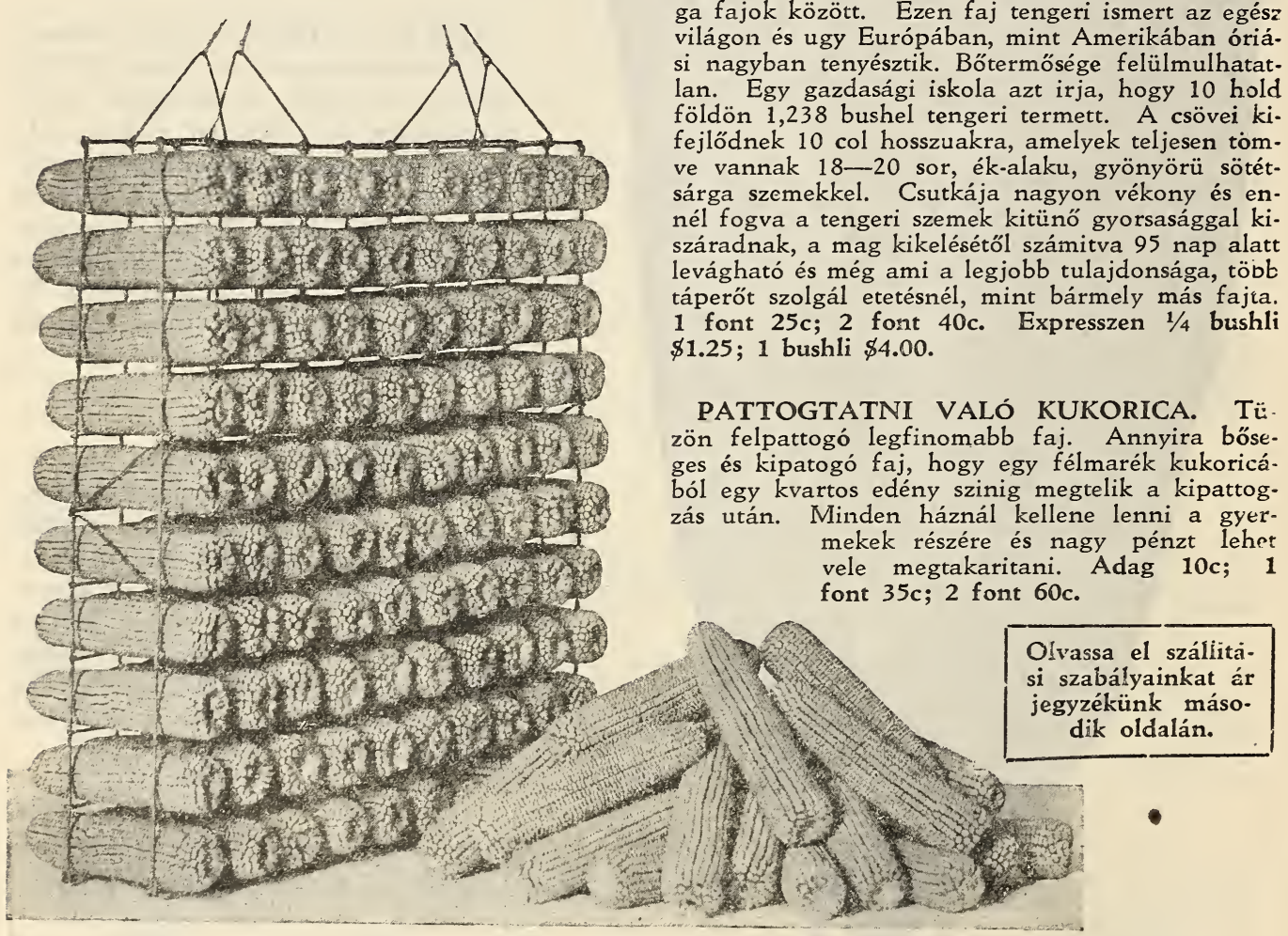

JAVITOTT LEAMING. A legjobb és a leg. ismertebb sárga tengeri (kukorica) az összes sár ga fajok között. Ezen faj tengeri ismert az egész világon és ugy Európában, mint Amerikában óriánagyban tenyésztik. Bötermősége felülmulhatatfejlödnek 10 col hosszuakra, amelyek teljesen tomve vannak 18-20 sor, ék-alaku, gyönyörü sötét-

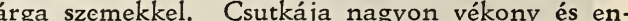
levágható és még ami a legjobb tulajdonsága, töbt táperőt szolgál etetésnél, mint bármely más fajta. 1 font 25c; 2 font 40c. Expresszen $1 / 4$ bushli $\$ 1.25 ; 1$ bushli $\$ 4.00$.

PATTOGTATNI VALÓ KUKORICA. Tü zön felpattogó legfinomabb faj. Annyira bőseges és kipatogó faj, hogy egy félmarék kukoricából egy kvartos edény szinig megtelik a kipattog. zás után. Minden háznál kellene lenni a gyermekek részére és nagy pénzt lehet vele megtakaritani. Adag 10c; 1 font $35 c ; 2$ font $60 c$. 


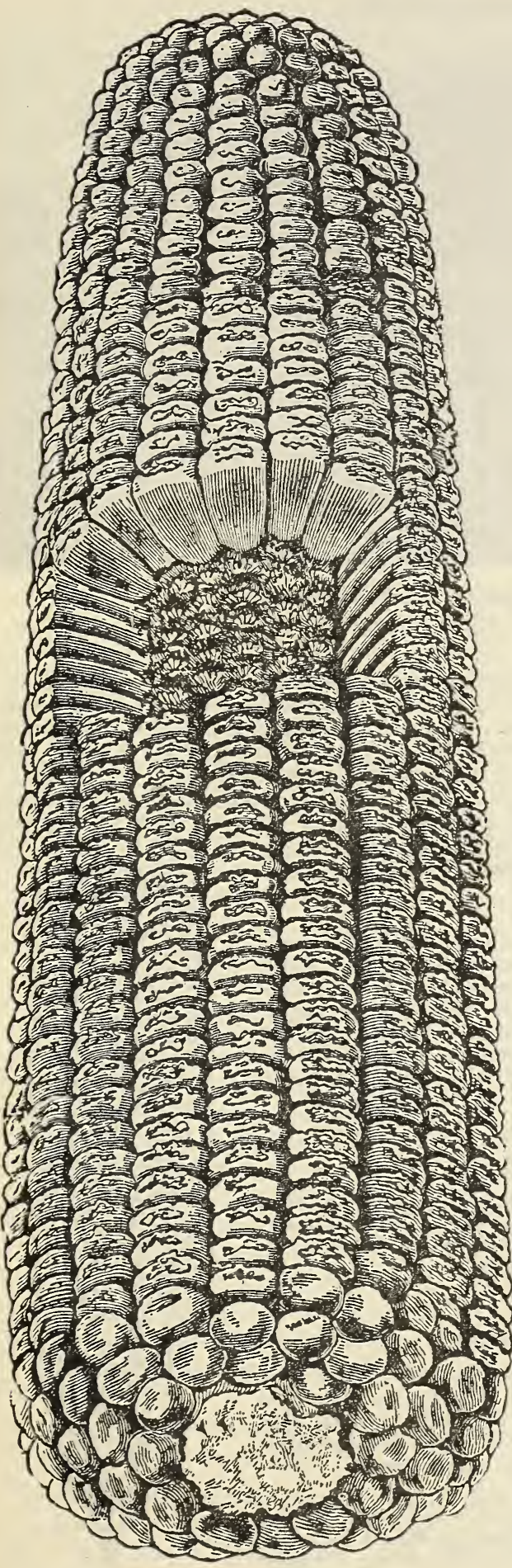

TENGERI (Kukorica). ÉSZAK BÜSZKESÉGE 80 napos tengeri. Nagyon bőtermő és korai. Egyike a legelterjedtebb fajoknak az északi vidéken. A csövek és a szemek nagyok. Postán 1 font 25c; 2 font $40 \mathrm{c}$. Expressen $1 / 4$ bushli $\$ 1.25,1$ bushli $\$ 4.00$.

SÁRGA FOGIDOMU. Megfelel bármely éghajlatnak és talajnak, nagy csövekkel. A mag külső vége fehér, belseje sárga. Érése 90 nap. Postán 1 font 25 c; 2 font 40 c. Expressen $1 / 4$ bushli $\$ 1.25,1$ bushli $\$ 4.00$.

KUBAI SZZÁR TENGERI. Valódi amerikai csalamádé kukorica. Levelei nagyon szélesek és hosszuak, szárai zsengék és lédusak. Zöld etetésre kiválóan alkalmas. Postán 1 font 25c; 2 font 40c. Expressen $1 / 4$ bushli $\$ 1.25,1$ bushli $\$ 4.00$.

\section{ADÓSSÁGTÖRLESZTÖ} A növény óriaisi nagyra nö és ennek dacára korán megérik, kikelèstől számitva 100 nap alatt levágha. tó. Szemei nagyon világos sárgák, csutkája kicsiny, átlag 2 csövet terem szárankint. Ajánlható olyan vidékekre, ahol igen forró a nyári höfok, minthogy a szemei a zsizsik fellépte elött megérnek, avagy keményednek meg. Postán 1 font 25c; 2 font 40 c. Expressen $1 / 4$ bushli $\$ 1.25$, 1 bushli $\$ 4.00$.

\section{LONGFELLOW-FÉLE} Nyolc soros telt szemü (éppen, mint a magyarországi), általában nagybani termelö fajta ugy itt Amerikában, mint Magyarországban. Hosszu csövei rendesen a tövétöl a hegyéig tele vannak szemekkel. Postán 1 font 25c; 2 font 40c. Expressen 1/4 bushli $\$ 1.25,1$ bushli $\$ 4$.

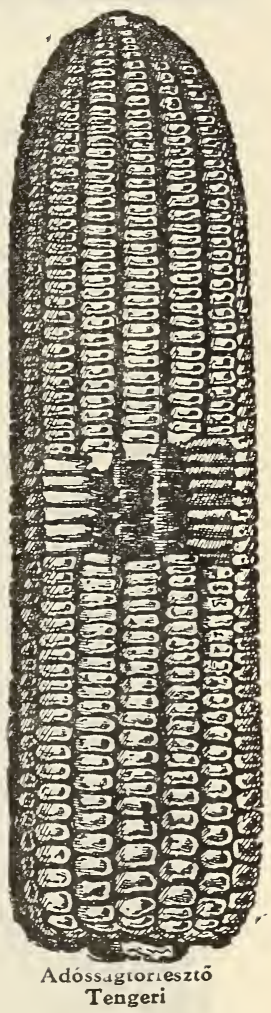

$\mathrm{Ha}$ városában nincs express hivatal (Express Office), nagyon kérjük a legközelebbi város nevét adni, ahol van ezen hivatalok egyike. 


\section{TAVASZI GABONAFÉLÉK.}

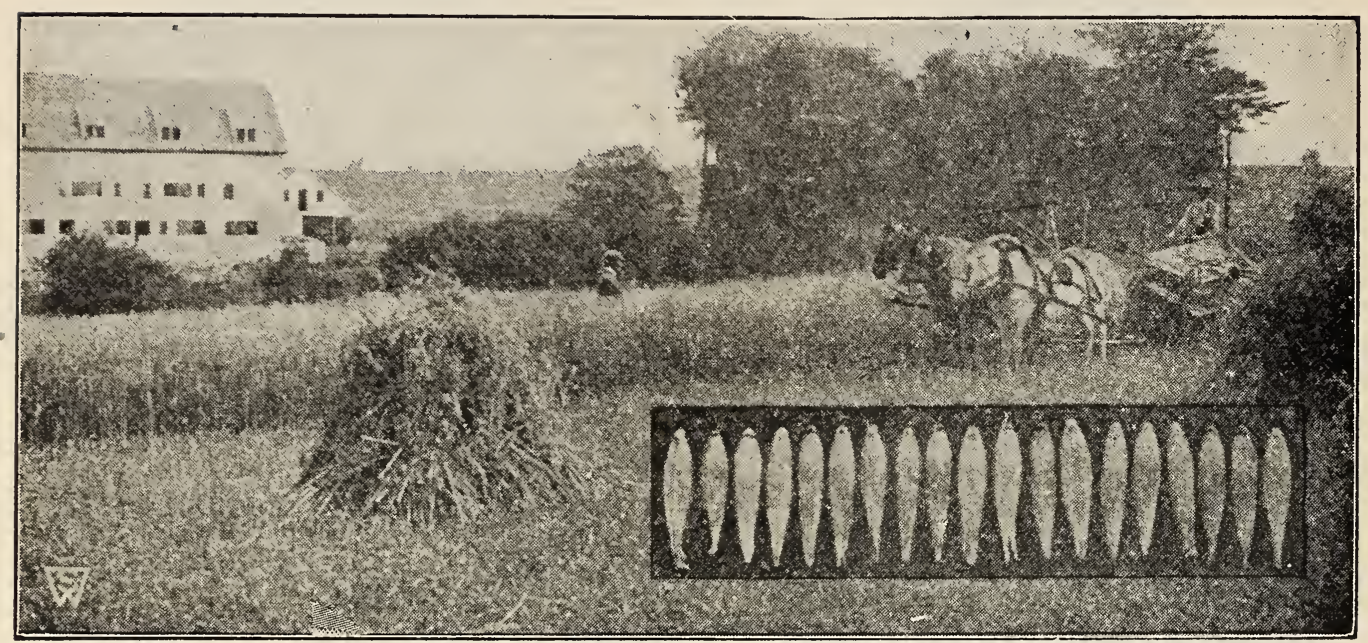

Kállay-féle svéd zabtábla egy magyar honfitársunk telepén.

A termés 104 bushli volt holdanként.

KÁLLAY-FÉLE SVÉD ZAB. Ezen elsőrendü és bőtermö gazdaságos zab Oroszországból lett be. hozva az Egyesült Államok gazdasági akadémiája által 1899-ben. Tiz évig gyakorlatoztak vele, tanul. mányozták bőséges termését, minőségét és hogy mi lyen talajban tenyészik legbővebben. Wisconsin állam gazdasági telepén tiz évi próba termelés alatt azt tapasztalták, hogy ez a svéd zab a tiz év alatt átlagosan $81 / 2$ bushlival több zabot terem holdankint, mint bármely más fajta.

A legnagyobb előnye a többi zab fajok között az, hogy ezen faj óriási messze kiterjedő gyökereket csinál ès ennélfogva bármely földben és bármely időjárásban bőségesen terem. Tehát annálfogva,

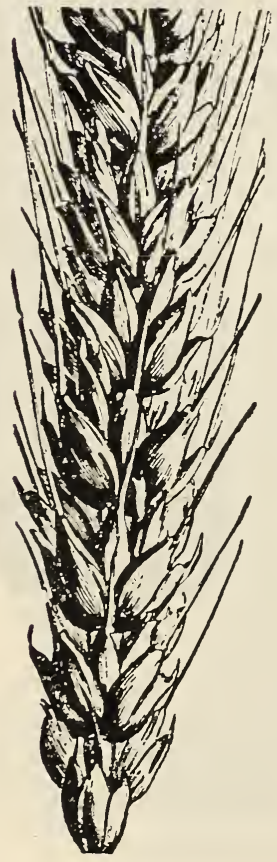

Tavaszi Buza hogy óriási gyökereket csinál, ugy elbokrosodik, hogy néha egy magból, egy gyökéren, 15 és 25 szál emel. kedik fel óriási fürtökkel.

Svéd zabot a legnagyobb sikerrel tenyésztik mindazon vidékeken, ahol csak zabot termelnek. Tehát azon farmer, aki bőséges termést akar, legyen az akár alacsony nedves, könnyü fekete, vagy sovány magaslatos földje, az rendelje meg ezen nemes zabfajt, mert csakis ezen fajt termelheti eredményesen. Vessünk 3 bushlit holdankint. 1 bushli $\$ 2.00,5$ bushli $\$ 9.00,10$ bushli és azon felül $\$ 1.70$ bushlija.

\section{Tavaszi Buza.}

MINNESOTAI. Szép, acélos szemü, szakállas általánosan termelt buzafaj. Bőtermőségével felülmul minden más fajokat. Nagy aranysárga kalászokkal. 1 bushli $\$ 4.00,10$ bushli $\$ 35.00$.

\section{Tavaszi Árpa.}

HATSOROS. Biztos és óriási hozama folytán igen keresett hatsoros telt kalászu, általánosan ismert és termelt szakállas korai árpa. Bőtermő, fegyálló, erős növésü és nagy hasznot hozó faj, amely minden talajra alkalmas. 1 bushli $\$ 3.00,10$ bushli $\$ 28.00$.

UJ SZAKÁLATLAN. Igen szép, telt szemü. Szálka nélküli árpa, sokkal bővebben terem, mint a hatsoros, különösen szereti a magas, homokos talajt. 1 bushli $\$ 3.00,10$ bushli $\$ 28.00$.

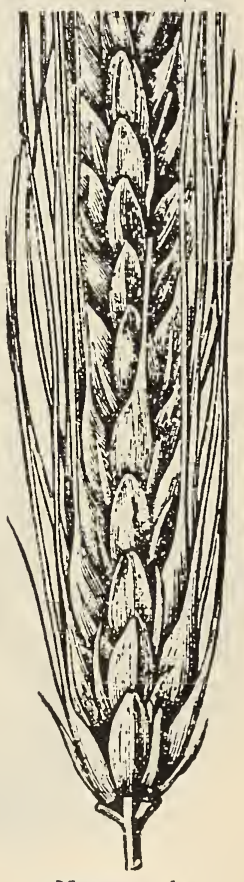

Hatsoros Ápa 


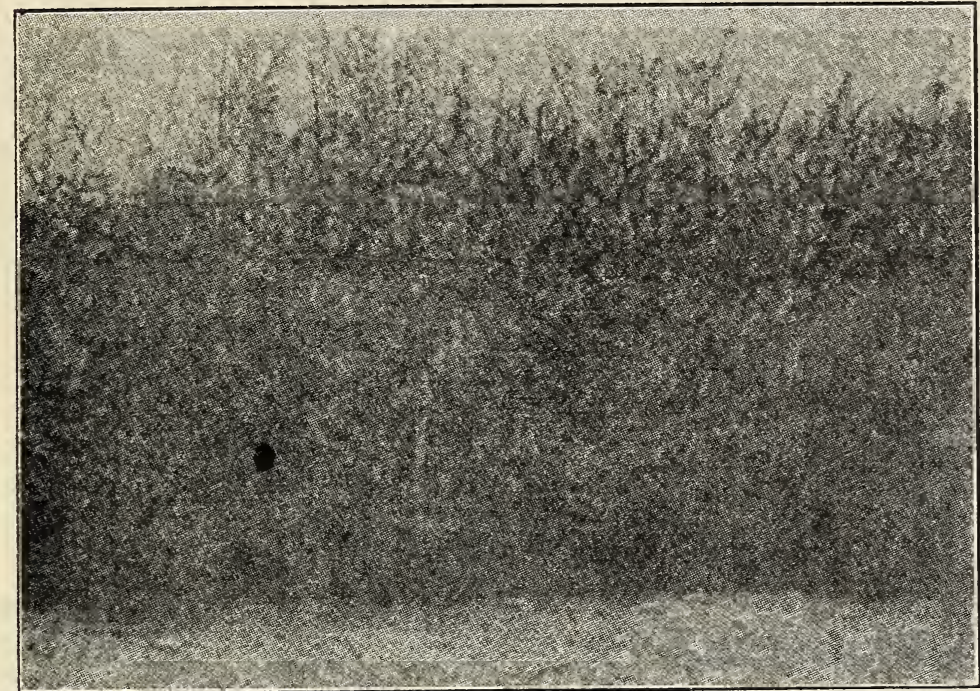

110 Napos Hubam Lóhere Tábla
Ezen alábbi cikket egy magyarországi lapból vettük:

Az Egyesült Allamok egyik államának, Alabamának egy tudós tanára egy uj herefaj. tát termelt ki, mely méltán kelt nagy feltünést nemcsak Amerikában, hanem Európa azon országaiban is, ahol ezt a fajtát kipróbálják. Hubám here a neve $s$ magvát a te. nyésztő tanár sokaknak ki. osztotta kipróbálás végett. $\mathrm{E}_{z}$ a lóhere nem két, hanem csak egy éves és ugy takarmány nak, mint zöld trágyának ikitünô. Egy kolumbiai farmer leirja egy amerikai ujságban, hogy náluk próbára vetettek egy darab földbe Hubám ló. herét május 1-én; a vetés julius 17-én már 120-150 centiméter magas volt. Julius 17 -étől augusztus 6-ig (21 nap) ismét 80 centimétert nőtt a Hubám (átlagban a nagy meleg napokban 5 centi métert). Tehát a leirás sze. rint embermagasságnál is na. gyobbra fejlödik az uj here. fajta.

Az 1921. évi nagy szárazságot a Hubám fényesen kiállotta. Az egyik kisérletezö tudatja, hogy náluk ugyszólván alig volt eső és a Hubám mégis 130 centiméter magasra nött.

Bamulatosnak mondják a Hubám magtermését is. Egyik tenyésztő próbára 12 deka Hubám magot vetett; a vetés 150-240 centiméter magasra nött és magnak hagyva, 270 kiló magot adott. Ha ez igy igaz, akkor egy hold földön vigan lehetne egy millió korona értékü Hubám magot ter melni.

A Hubám minden talajjal megelégszik; természetesen a jó termöeröben levő földben jobban diszlik. Amerikának Ohio, Michigan, Dakota, Alabama, Columbia államaiban óriási Hubám-mezök vannak. Európa államai közül tudomásunk szerint még csak Olasz. és Angolországban termelik.

Jó volna, ha a többi európai államokat mi megelőzhetnènḱ a termeléssel és a szomszédos országokat mi láthatnánk el Hubám-maggal. Ilyen módon lehetne valutát javitani. Min denki irjon amerikai ismeröseinek, hogy küldjön Hubám lóheremagot, ha többet nem, legalább egy levélboritékkal (az amerikai postahivatal megmondja, hogyan lehet feladni a küldeményt.) A legcsekélyebb maggal is kisérletezhetünk. Próbáljuk ki mindjárt egy részét védő nōvénnyel vetve is

Ha semmit se próbálunk, akkor semmire se megyünḱ! Ha van sok takarmány, akkor lehet sok állat, sok trágya, jó föld, sok termés.

A kisérletek eredményét tudassuk másokkal is.

GÖRÖG ERNÖ.

\section{HUBAN LÓHERE UJDONSÁG.}

Ezen lóhere faj a leghasznosabb, amit ezideig még feltaláltak a gazdálkodók részére. Egynyári Lóhere faj, tehát tavaszon elvetjük, Zab vagy más gabona hegyé és már azon az éven 3-4 láb magasra fejlödik. Akár szárazon, akár zölden, állatoknak elsőrendü takarmányt szolgáltat. Azonfelül alászántásra szintén elsőrendü, például őszön elvet Buzát vagy Rozsot, vagy tavaszon Árpát, vagy $\mathrm{Za}$. bot, Április 15-ikén szintén elveti hegyéje a Huban Lóhere magot; mikor a gabona megérik, learatja és a Huban Lóhere aratás után legkésőbb hat hétre 3-4 láb magas. Akkor alászántjuk és oly hasznos mütrágya, hogy leszántás után földje bármiféle nö. vényt megterem.

Postán bérmentve 1 font $60 c$; 3 font $\$ 1.60$. Expresszen 5 font és azon felül $50 \mathrm{c}$ fontja..

Európa bármely részébe postán, ingyen szállitva: 1 ounce ( 1.16 font) $30 c ; 1 / 4$ font $60 c ; 1 / 2$ font $80 c ; 1$ font $\$ 1.25 ; 3$ font és azon felül $\$ 1.00$ fontja.

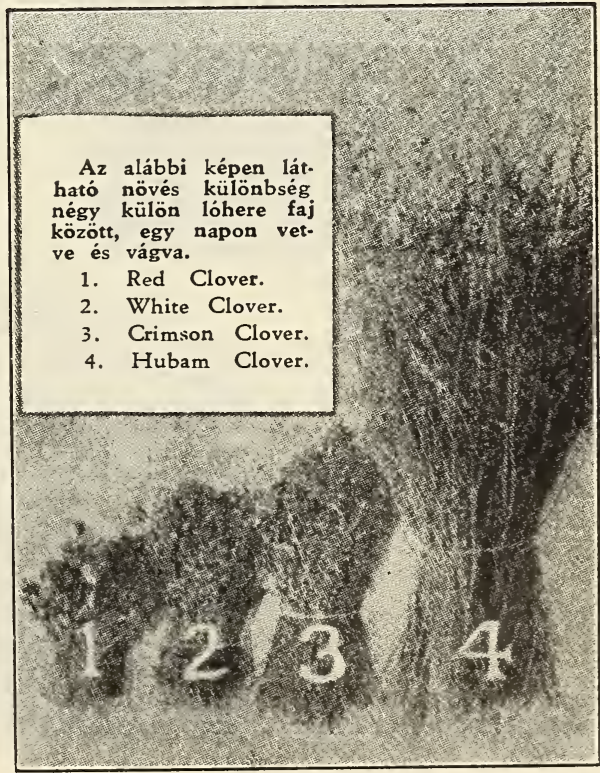




\section{LUCERNA ÉS LÓHERE MAGVAK.}

$\mathrm{Az}$ itt felsorolt gazdasági magvak árai változásnak vannak alávetve $s$ igy az árak csak kisebb mennyiségekre nézve vannak feltüntetve. Nagyobb mennyiségek vételénél mintával $s$ napi árak közlésével szivesen szolgálunk.

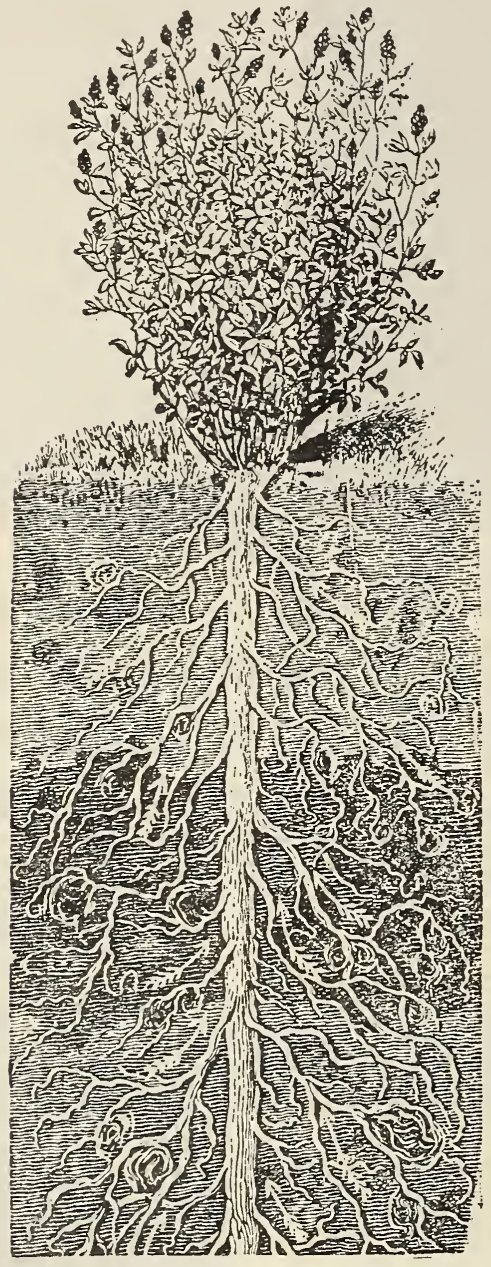

Lucerna

LUCERNA. (Medicago sativa.) Legelső rendü, nagy szemü, kiváló minőségü, legnagyobb csi. raképességü és legtisztább magyar faj. Postán: 1 fant $50 \mathrm{c} ; 3$ font $\$ 1.40$. Expresszen: 5 font éd azon felül $40 \mathrm{c}$ fontja.

SVÉD VAGY KORCSHERE. (Trifolium hy. bridum.) Nedves rétekre igen ajánlható, évelö, a fagyot kiállja. Postán 1 font 50c; 3 font $\$ 1.40$. Expresszen: 5 font és azon felül $40 \mathrm{c}$ fontja.

BIBOR LÓHERE. (Trifolium incarnatum.) Ezen faj annyiban különbözik a vörös léherétöl, hogy sokkal nagyobbra nö, dusabb termó és zöld etetésre a legalkalmasabb. Postán: 1 font 50c; 3 font \$1.40. Expresszen 5 font és azon feliil 40 c fontja.
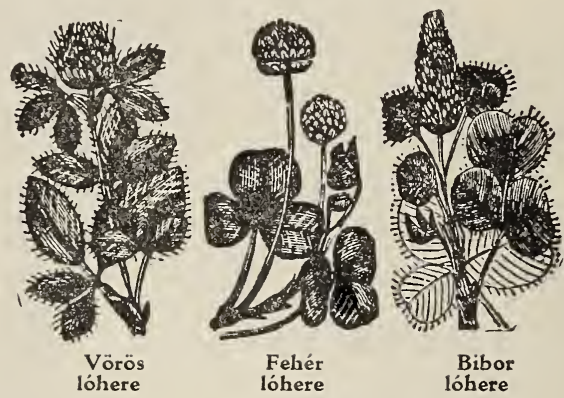

FEHÉR VAGY RÉTI HERE. (Trifolium reyens.) Kitünő minőségü mag. Rétekre igen ajánlható. Minden jobb talajban diszlik. Postán 1 font $\$ 1.00 ; 3$ font $\$ 2.75$. Expresszen 5 font és azon felül 80 c fontja.

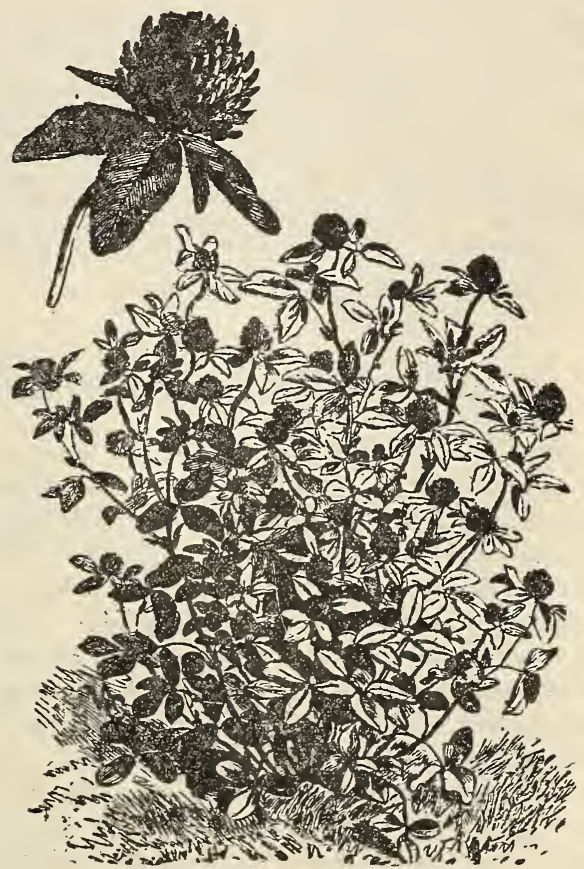

Vörös Lóhere

VÖRÖS LÓHERE.( Trifolium pratense.) Leg kitünőbb a takarmányok között, ugy zölden, mint szárazon, a leghaszriosabb takarmány és nagyon szapora jó talajban. Postán 1 font $50 \mathrm{c} ; 3$ font $\$ 1.40$. Expresszen 5 font és azon felül $40 \mathrm{c}$ fontja. 


\section{KÜLÖNFÉLE MEZÖGAZDASÁGI MAGVAK.}

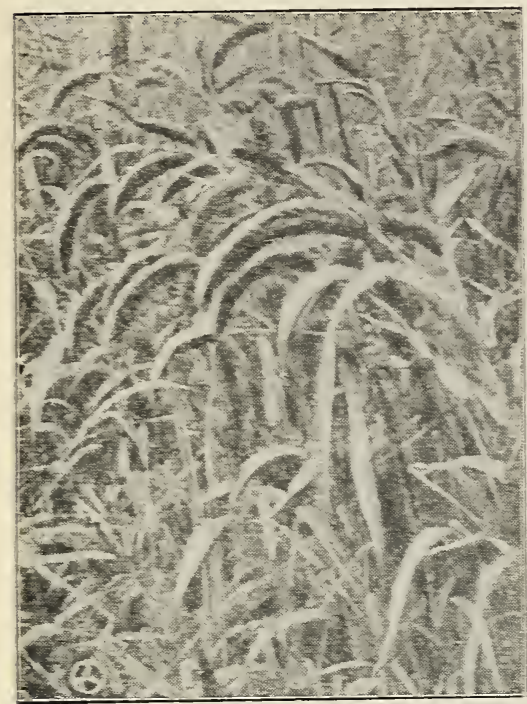

Magyar Muhar

Az árak kōtelezettség nélkül értendök. Nagrobb meny. nyiségek vételézél tessék napi árfolyamért imi.

MAGYAR MUHAR. Ezen nemes takarmány minden mastar gazdalkodo ember elöt nasyon ismeretes. Minden talajban böven terem s csak nagyon nulságos nedressègtool szenved kárt. Vetés ideje idóleges, lehet máz május elejen retni, akkor már junius utólján használhatja aká: zöld etetésze, akár telire felszárogatni. Azonkivil lehemég junitus utólján is remi, ami arra jó, hosy mikor már a legelök silányak, augusztus. szeptemberben zöld muharrai lehet pótolni tehenek és lovak részére. Bámulatos gyorsan nörö és olr bösèges, kogy néha $6-8$ ton takarmán terem holdarkint. Postán 1 font 35c. Expresszen IC font és azon felul $10 \mathrm{c}$ fontja.

KOLES. Kōzönséges kōles amelynek szára állatok ete tésére. magia pedig csirkék etetésére kitinö eledelt szol gáltat. Postán 1 font 35c. Expresszen 10 font és azor felül $10 c$ fontja.

LENCSE. Lezszeלb nagy magu, tiszta, ehetō fözelúk nek is. 1 font $40 \mathrm{c} ; 10$ font és azon felül $30 \mathrm{c}$ fontja.

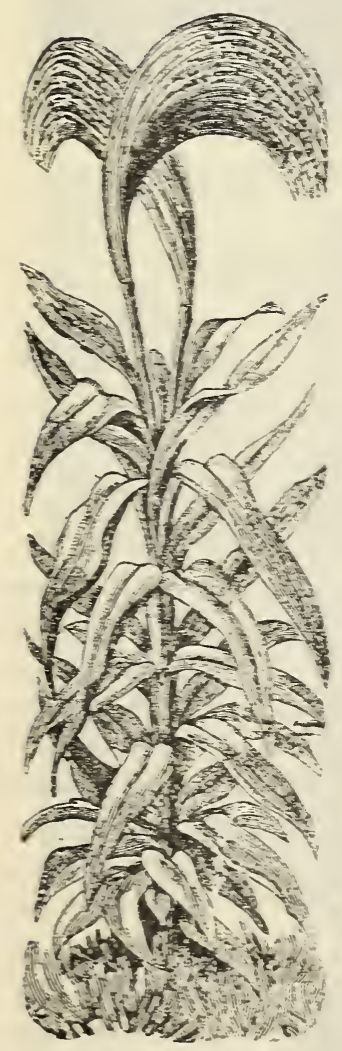

Sepró Ciroḱ
POHÁNKA VAGY HAJDINA. Az álaláno san ismert és használt hajdina faj. Korai és meg. marad virágzásban torábbra, mint bármely más faj. A magia grönyöri, világos szürke. Pcstán 1 font $25 \mathrm{c} ; 3$ font $60 \mathrm{c}$. Expresszen 10 font és azon felü $10 c$ fontja. (52 font ran egy bushelben.)

NAPRAFORGÓ. Ótiási, 1 font 30c.

SEPRŌ CIROK (Sorghum Vulgares.) Ezen nō. vény tenyésztése a leggazdagabban fizet az ōsszes zazdasági terménrek kōzört. Már több, mint mégy éve tisztitott, seprönek raló cirokér: fizetnek 300 dollárt tonnájáert, ragyis 15 cent fontja és egy holdon 2-4 ionna száritott cirok terem meg. Postún 1 font $40 c ; 3$ font $\$ 1.00$. Expresszen $j$ font is azon felul $30 c$ fontja.

\section{TAKARMÁNY TÖK.}
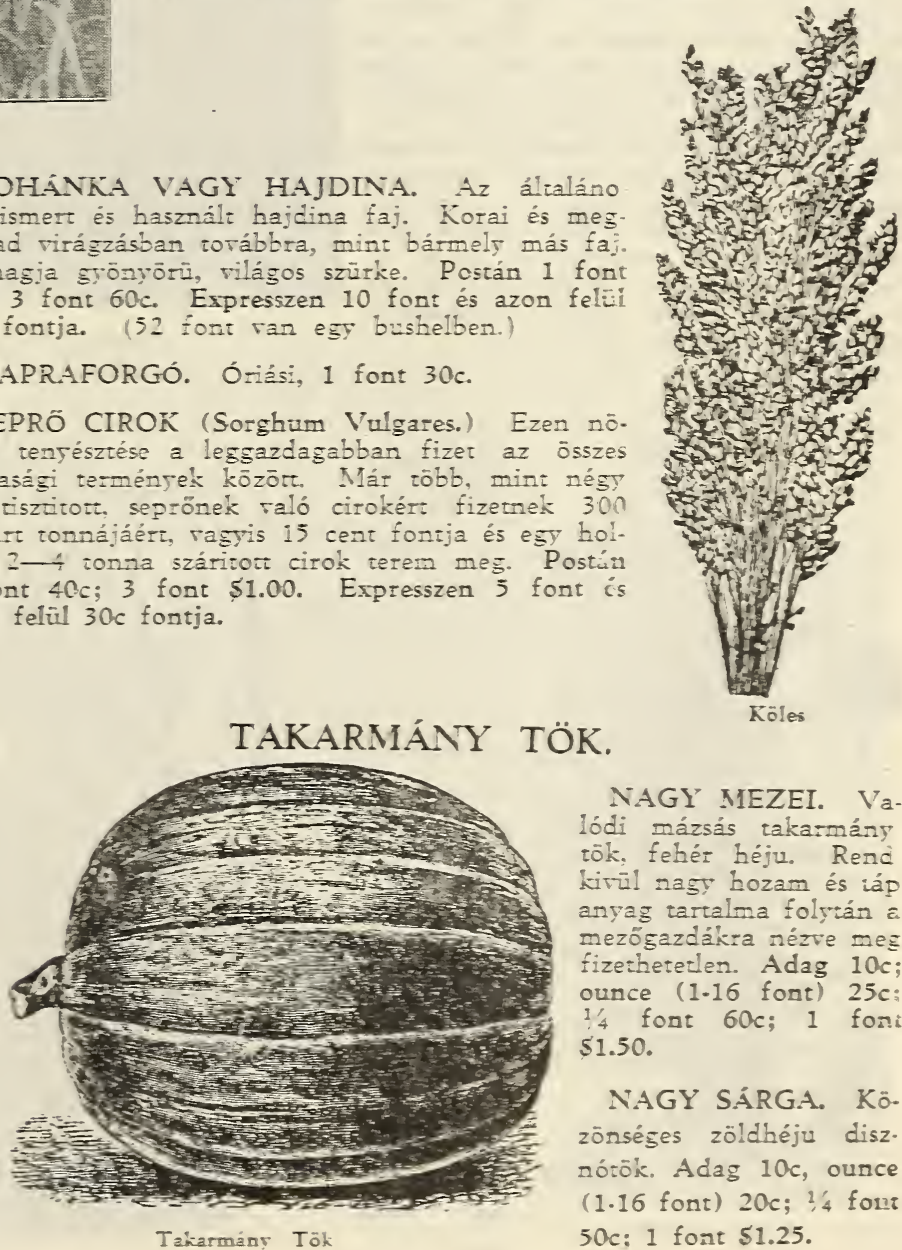

NAGY MEZEI. Va lódi mázsás takarmány tōk, fehér héju. Rend kivull ragsy hozam és iáp anyag tartalma folytán a mezógazdákra nézve meg fizethetetlen. Adag 10c; ounce ( 1.16 font) $25 \mathrm{c}$ : $1 / 4$ font $60 \mathrm{c}$; 1 fon: $\$ 1.50$.

NAGY S.ARGA. Kö. zōnséses zöldhéju disz. nótōk. Adag 10c, ounce ( 1.16 font) $20 c ; 2,4$ font 50c: 1 font $\$ 1.25$. 


\section{TÉLI VAGY HOMOKI BÜKKÖNY.}

VICI VILLOSA. Ezen hasznos takarmányt azért nevezték el téli bükkönynek, mert ezen fajtát nemcsak tavaszon, de ö. szön is lehet vetni. A homoki nevet meg onnan nyerte, hogy a legsoványabb ho. mokban is bö termést hoz. Például van. nak földek, ahol a lóhere nem nő meg, a homoki bükköny ugyanott $4-6$ ton ta. karmányt szolgáltat holdankint. Egy másik és a legnagyobb értéke ezen növénynek pedig az, hogy amely földben termelik, azon földben \$14-től \$45 értékü trágya helyett szolgál és pedig azért, mert ezen növény levelei a nitrogént leszedik a levegőbõl és a gyökerek által átadják a föld. nek. Vetés ideje a következő: Lehet vetni és pedig a legjobb vetés ideje április hónap; junius utolján meg lehet kaszálni, kaszálástól fogva egész a fagy beálltáig elsőrendü legelöt szolgáltat. Lehet vetni augusztusban és már szeptember elején elsőrendü legelöt ad egész a fagy beálltáig és azonkivül lehet vetni szeptember és ok tóber hónapokban és a következó nyáron elsőrendü legelő, vagy pedig juniusban meg lehet kaszálni. Egyedül vetve 60 60 font kell egy hold földbe. Ósszel rozszsal, tavaszon zab vagy árpával vetve, 40 font kell holdankint. Postán bérmentve: 1 font $45 \mathrm{c}$; 5 font $\$ 2.00$. Expresszen: 10 font és azonfeliil 25c fontja.

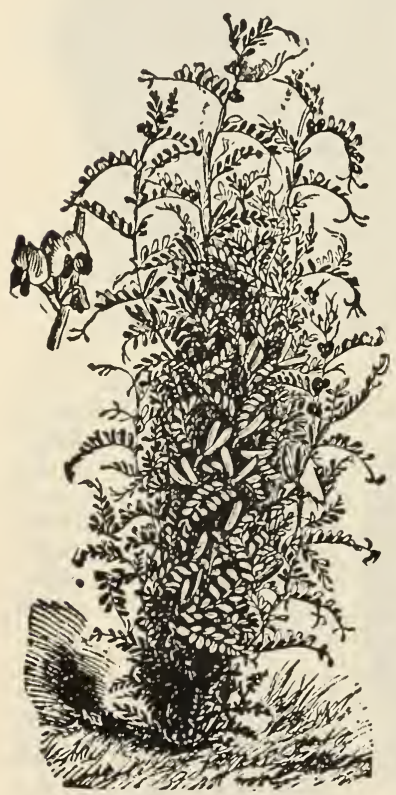

Tavaszi Bükkōny
TAVASZI BÜKKÖNY. (Vicia sativa.) Igazi magyar faj. Böven ka. szálható és termő zöld, ugyszintén száraz ta. karmány állatok eteté sére. Postán 1 font 30c; 3 font $80 c$. Expressen: 5 font és azon felül 15 cent fontja. $(60$ ft. van egy busliban.)

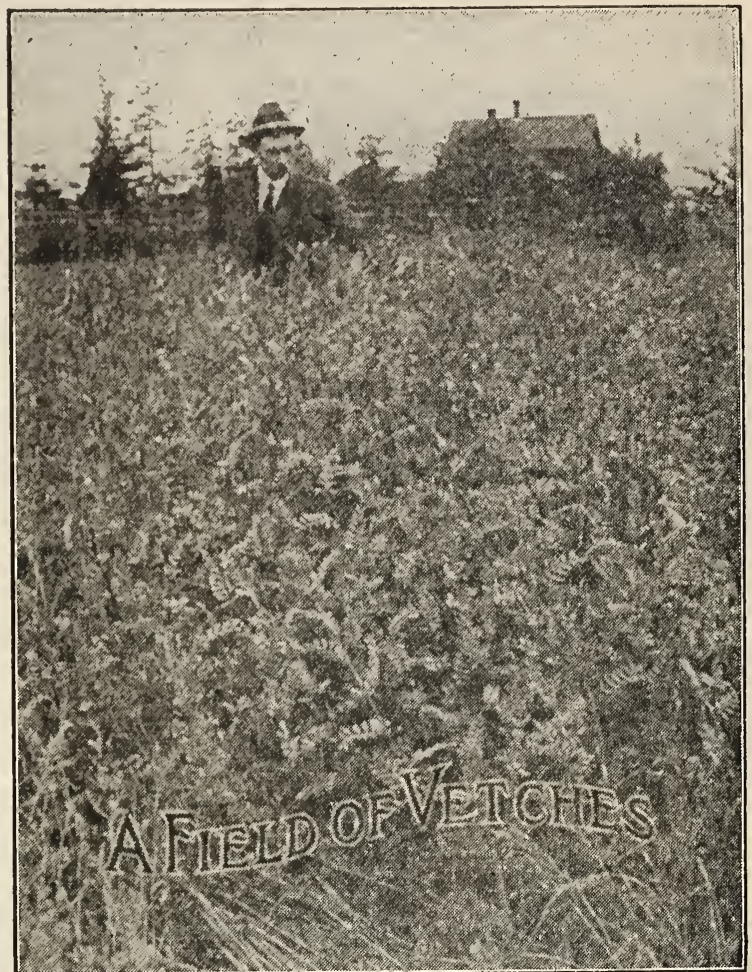

Homoki Bükköny, zabbal vetve

\section{FÜMAG-KEVERÉK.}

Ällandó rétek és legelök létesitésére. - Takarmány.

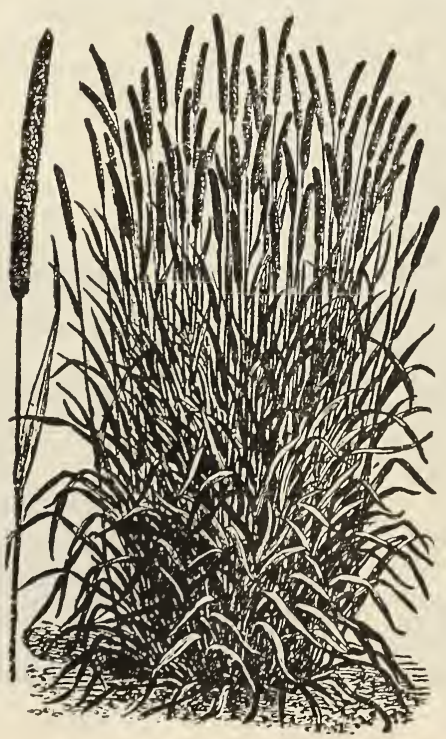

fümag keverékeink összeállitására a legjobb fünemüeket használjuk.

TIMOTHY FÜ, vagy réti komócsin Agyagos vagy ned vesebb talajon $\mathrm{ki}$ tünően diszlik. Jó és sok szénát ad. Ajánlatos vörös ló herével vetni. Postán: 1 font 30c; 3 font 70c. Expresszen: 10 font és azon felül $12 c$ fontja. (50 font egy busliban.) 
KASZÁLÓ KEVERÉK. Elsőrendü keverék ka. szálónak rétekre. Megrendeléseknél kérjük a mélyen tisztelt vevőinket a levélben feltüntetni, vajjon a mag alacsony, nedves, vagy magas, száraz talajba szükségeltetik-e. Postán 3 font $\$ 1.25$. Expresszen 10 font és azon felül 35c fontja.

LEGELÓ KEVERÉK. Gyorsan növő keverek. legelökre. Kérjük itt is a talaj feltüntetését. Postán 3 font $\$ 1.25$. Expresszen 10 font és azorı felül 35 c fontja.

GYÜMÖLCSÖS KEVERÉK. A legfinomabb fümagvak keveréke gyümölcsösök, vagy árnyékos helyekre legelönek. Nagyon gyorsan nö. Postán 3 font \$1.25. Expresszen 10 font és azon felül $35 \mathrm{c}$ fontja.

Fümag-keverék tartós és szép kerti pázsitok számára.

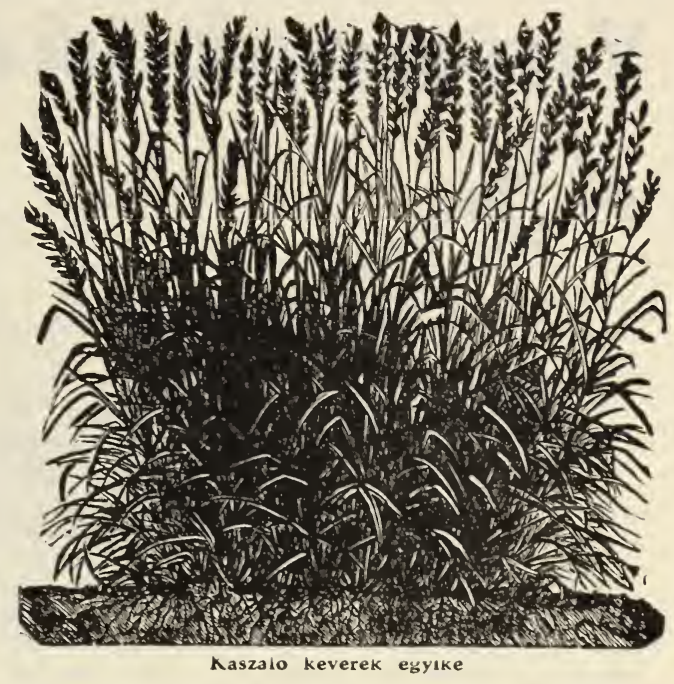

Ha házunk körül stb. szép, egyenletes és tartós kerti pázsitot akarunk elérni, a következőket kell figyelembe venni: Elöször is a vetéshez tiszta és csiraképes magot ve. gyünk, azt jól megmunkált és porhanyitott föld felületére egyenletesen elszórjuk. Ennek megtörténte után a magot gereblyével sekélyesen bevágjuk, deszkàval vagy lapattal egyenletesen leverjük és kikelésig - ha az idő száraz - többször megöntözzük. Száraz időben a pázsit állandóan locsolandó és 2-3 heti időközben géppel vagy kaszával levá. gandó. A gaztól, gyomtól tisztán tartsuk.

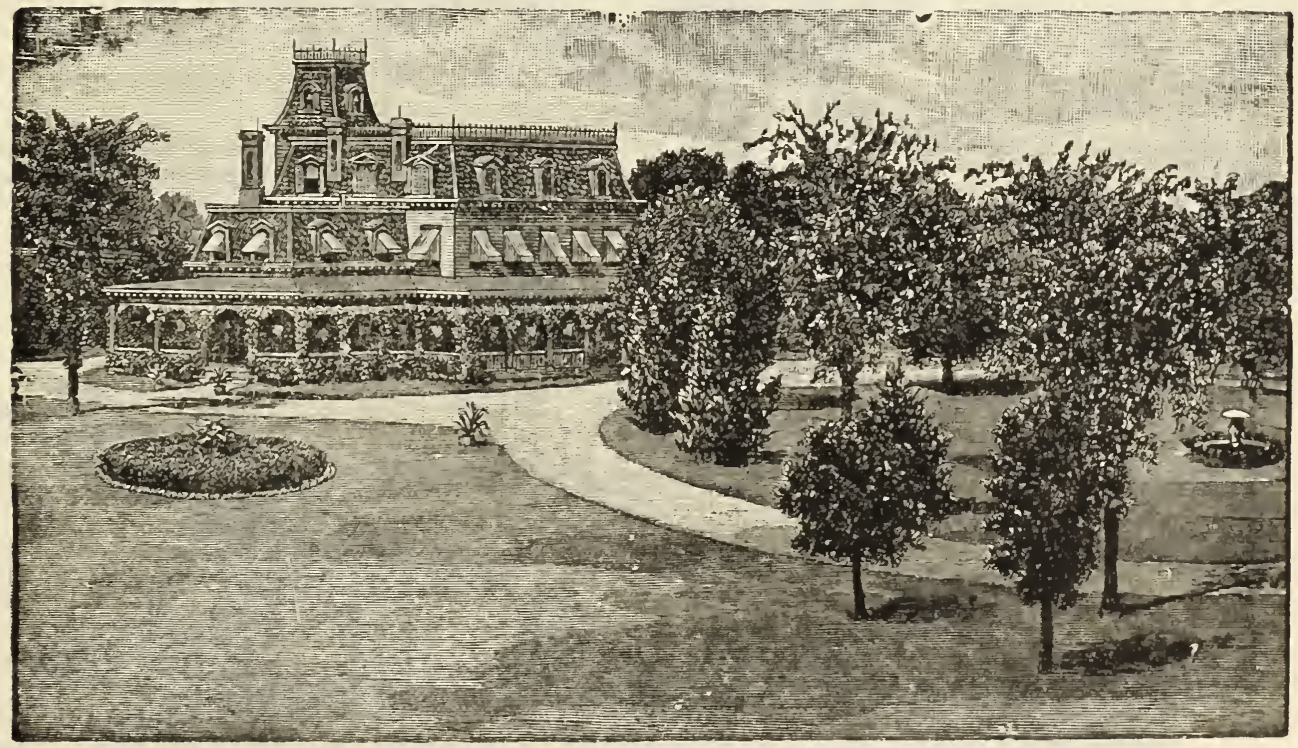

PÁZSIT KEVERÉK ÁRNYÉKOLT RÉSZEK. RE. Fával vagy egyéb árnyékolt helyeken kıtünően diszlik. Postán 1 font 60c; 3 font $\$ 1.70$. Expresszen 5 font és azon felül $40 c$ fontja.
BÁRSONY PÁZSIT FÜMAG-KEVEREK. A legfinomabb zöld bársonyhoz hasonló kerti pázsitot szolgailtatja. Postán 1 font $60 \mathrm{c} ; 3$ font 1.70. Expressen 5 font és azon felül $40 \mathrm{c}$ fontja. 


\section{Vegyes gazdasági és kerti szerszámok}

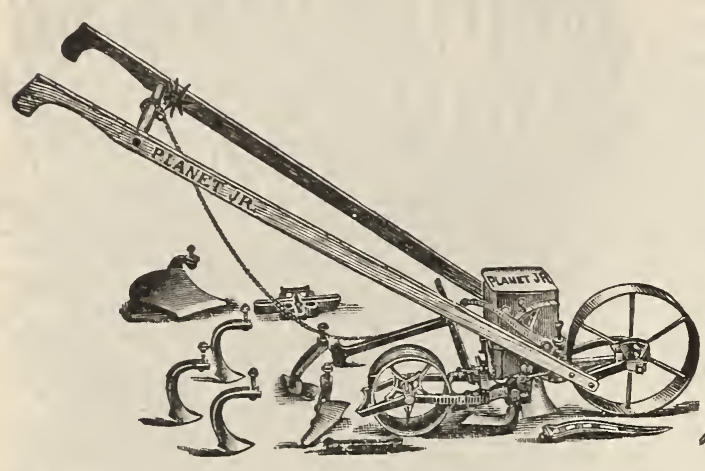

NO. 4. Planet Jr. egyesitett kézi halom és sorvető gép, ugyszintén szántó és kapáló. Vet. hető vele bárminemü konyhakerti mag, u. m.: hagyma, petrezselyem, sárgarépa, vörös répa, bab, borsó, stb. Igen könnyen kezelhető.

Darabja expresszen vagy teheráruként

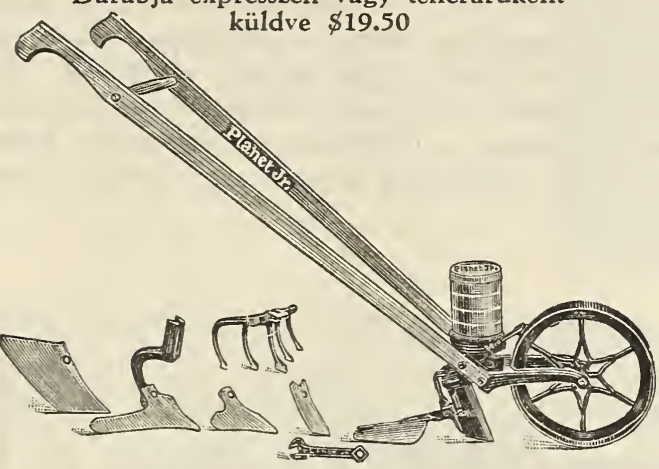

NO. 31. Planet Jr. egyesitett kézi sorvető és kapáló gép. Használható mindennemü magvetésekhez ugy, mint az előbbi. Nagy elterjedtségnek örvend kertkedvelök körében.

Darabja' expresszen vagy teheráruként

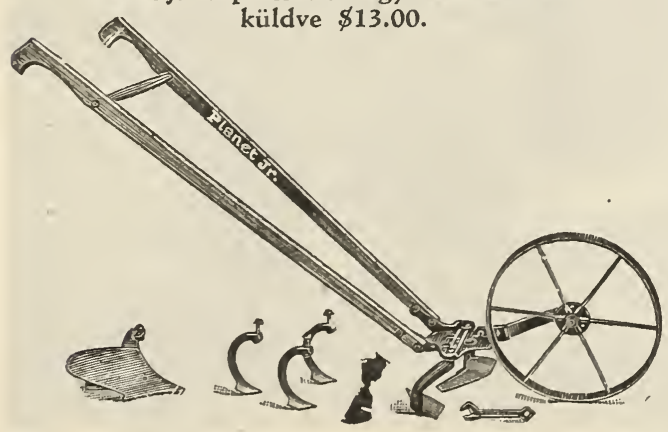

No. 17. Planet Jr. egykerekü kézi kapáló és porhanyitó eke. Nélkülözhetetlen minden kertkedvelönek. Gyorsan és tisztán tarthatja a kertjét mindenki, ha egy ilyenniel rendelkezik.

Darabja expresszen vagy teheráruként küldve $\$ 8.75$

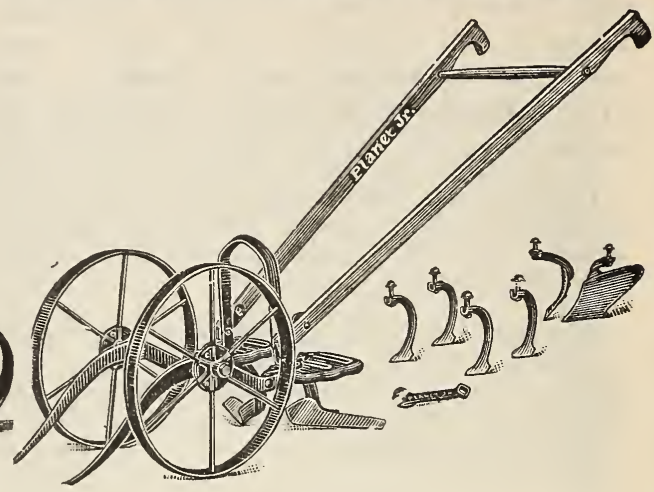

No. 12. Planet Jr. kétkerekü házi kapáló, porhanyitó és töltő eke. Teljes fölszereléssel.

Darabja expresszen vagy teheráruként küldve $\$ 11.50$.

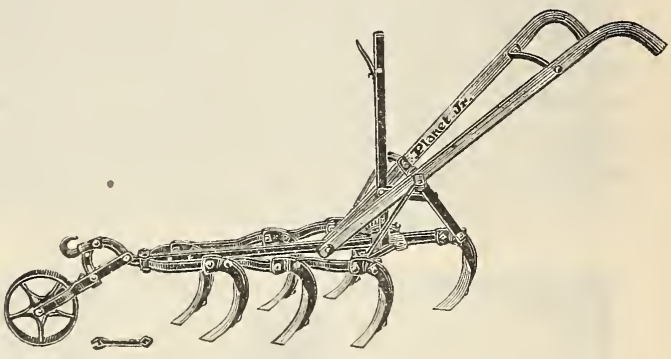

No. 101. Planet Jr. egy lovas porhanyitó eke. Nagyon ajánlható, igen könnyen járó gazdasági eszköz.

Darabja expresszen vagy teheráruként küldve $\$ 12.60$.

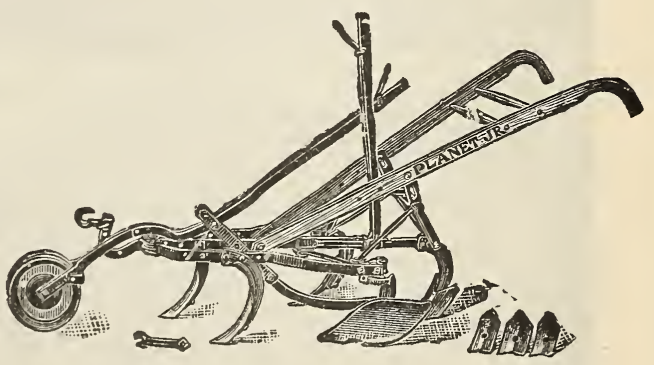

No. 8. Planet Jr. egylovas kapáló eke. Nagyon könnyü kerti eszköz, ahol egylovas kapáló eke szükségeltetik, különösen zöldségtermelök és gaz. dálkodók részére.

Darabja expresszen vagy teheráruként küldve $\$ 18.50$. 


\section{Vegyes gazdasági és kerti szerszámok}

Palántaszedő. Palántaszedő és ültető kanál. 50c.

Ágfürészek. Rendkivül éles ágfürészek diófa markolattal. $\$ 1.25$.

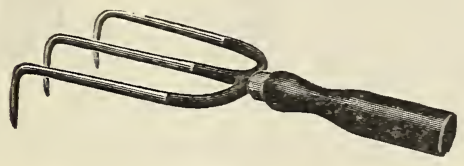

Gyomláló

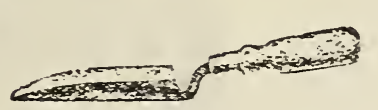

Gyomláló. Ügyes kézi gyomláló eszköz. 50c.
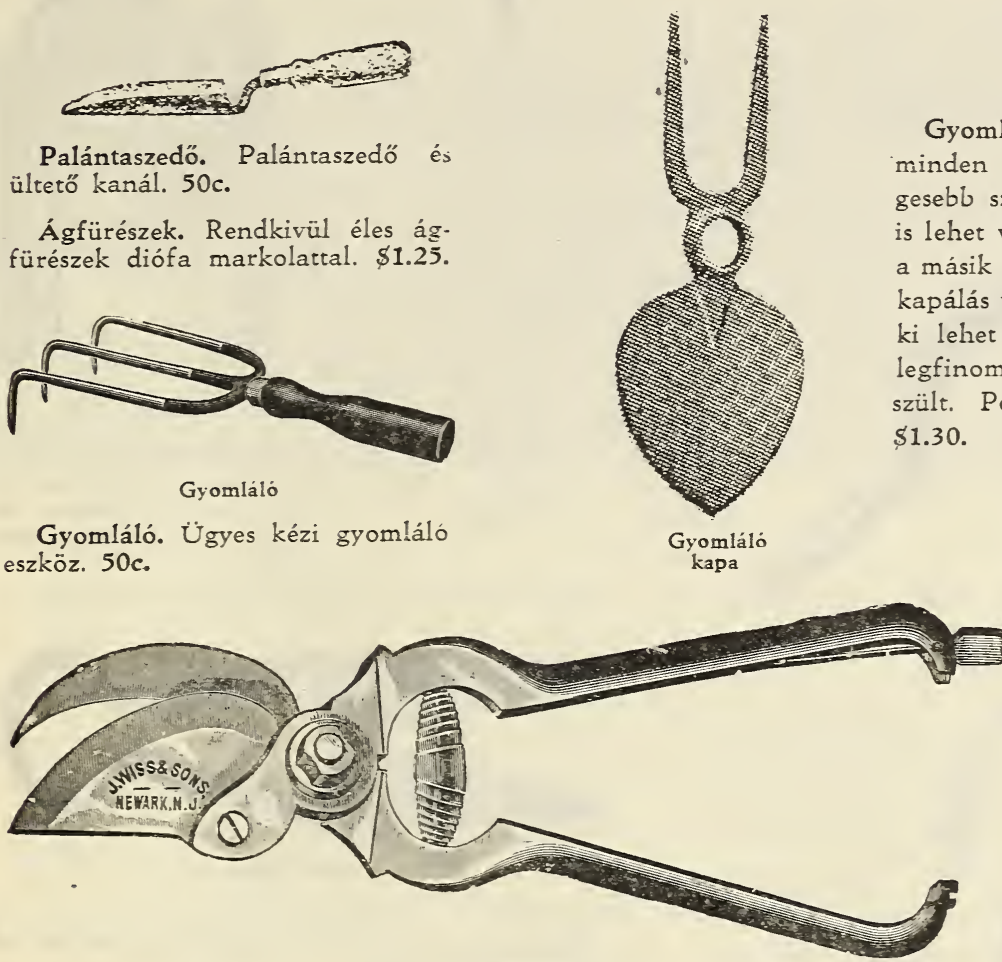

Kerti olló

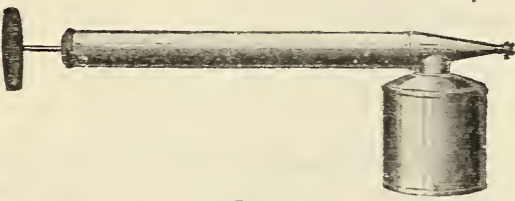

Permetezö

Permetezö. Rozsdamentes bádogból készült. Alkalmas minden rovar pusztitására. Használható akár folyadék, akár porszem szórásra. \$1.35.
Hömérök. Finom kivitelben. $\$ 1.25$ és $\$ 2.00$.

Sövenny Olló. Könnyü sövény olló. Szép alaku sövények ala. kitására nélkülözhetetlen szerszám. $\$ 2.50$ és $\$ 3.00$.

Gereblyék. Tartós kerti, vas. ból készült gereblyék. \$1.50.

Ásóvilla. Ásásra alkalmas kerti eszköz. \$2.00.

Lapátok. Vas lapátok több. féle nagyságban. $\$ 2.00$.
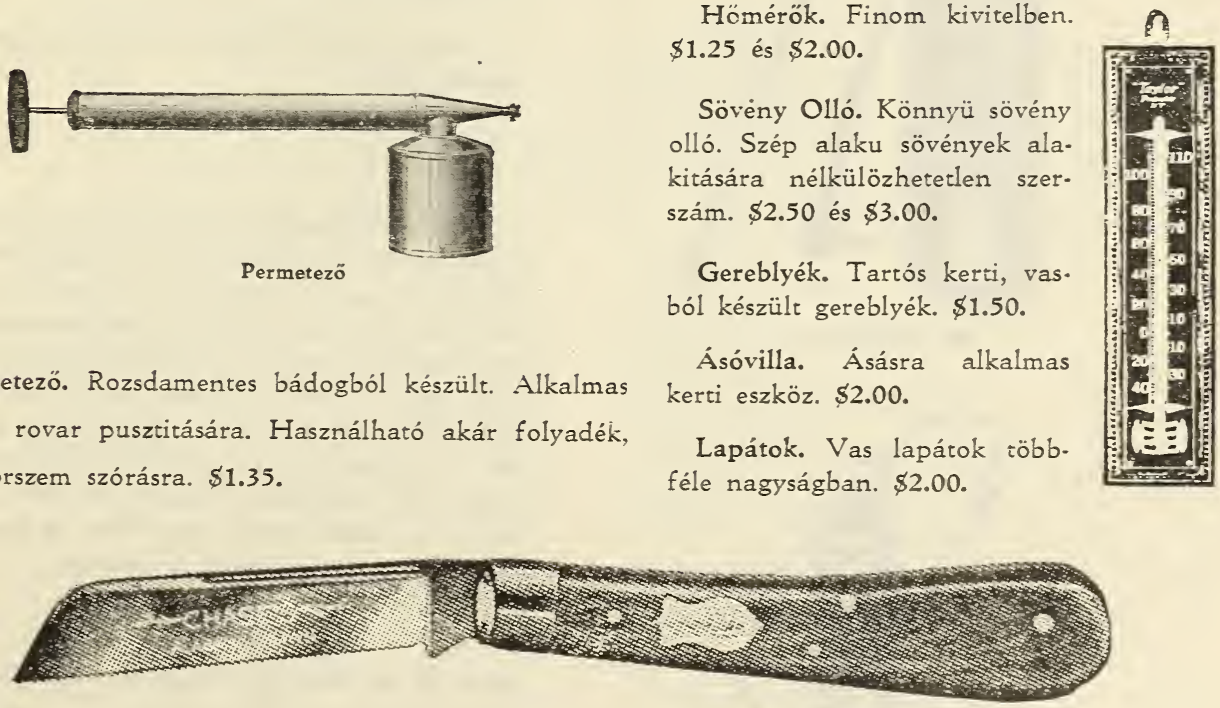

Ojto Kes

Ojtó Kés. Legkitünőbb acélból készült ojtó kés, nagyon könnyü és azonfelül erősen készitett, ébenfa markolattal. Darabja \$1.25. 


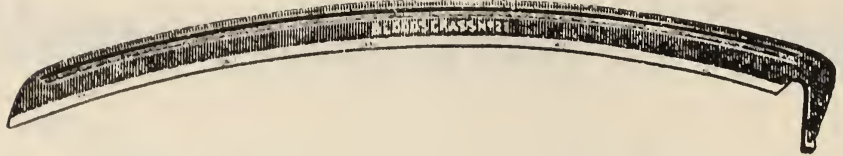

Amerikai Acél Kasza

Kaszák. Finom acélkaszák \$2.50.

Kasza-nyelek. Finomul kidolgozva $\$ 1.75$.

Kaszakövek. Finom minőségü. 40 cent.

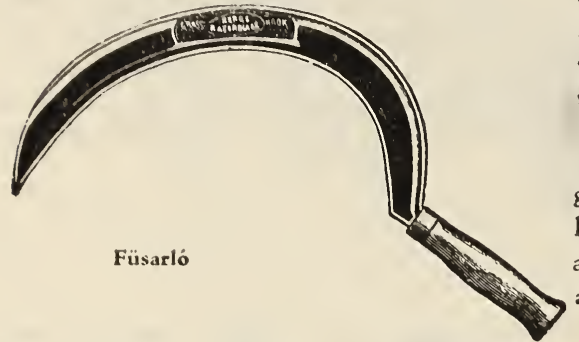

Pázsitkaszáló. Nágyon könnyen járó pázsitnyiró gép, 4 acélkéssel. $\$ 12.00$ és $\$ 14.00$.

Bor prés. Kitünö gyártmány. - Kisebb használatra nagyon alkalmas. - Tessék árakért irni.

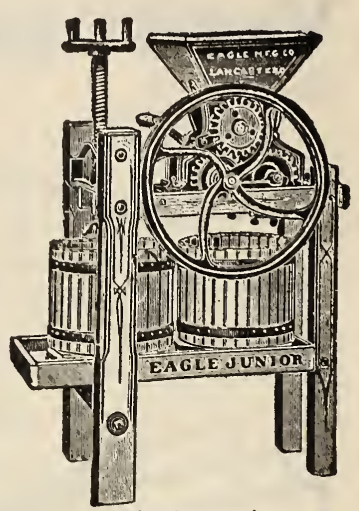

Almabor Prés

Almabor prés. Almabor prés vagy szájder (cider) készitésére alkalmas ki sebb prés. Tessék árakért irni.

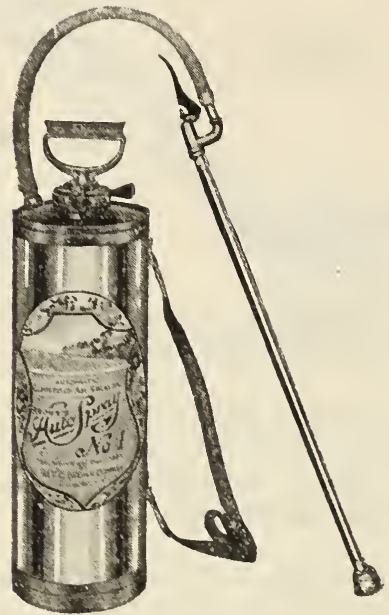

Hát Fecskendezö

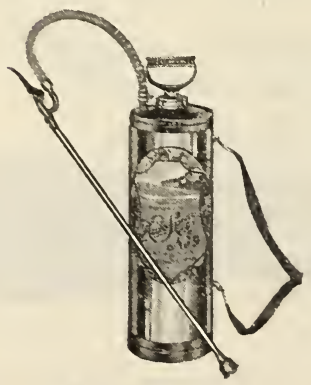

Hàt Fecskendezô

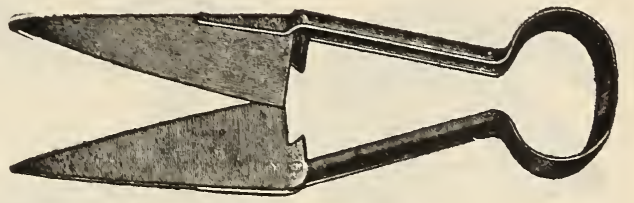

Pázsit Olló

Pázsit olló. Szegély és fák körül fünyiráshoz nél. külözhetetlen. $\$ 1.00$.

Tengeri ültetö. Általánosan használt kézi tengeri ültető. $\$ 3.50$.

Hát fecskendezö. Ezen kitünő fecskendező nél. külözhetetlen ugy farmokon, mint házaknál. Használható krumpli (burgonya), gyümölcsfák és bár. mely növényrovar ellen való fecskendezésre. Istál. lók, tyukház mésszel való fecskendezésére. Kazán nagysága 4 gallon és mikor már a folyadékot beletesszük, 3-4 col üreget hagyunk a kazánban, ekkor jól lezárjuk és a kazán közepén álló szi. vattyuval (pomppal) erősen levegỗt nyomunk bele és a belenyomott levegő képes a bentlévő fo. lyadékot erős nyomással kinyomni.

Auto Spray No. 1B-Sárga Réz 31/2 Gall. $\$ 9.50$ Auto Spray No. 1D-Rozsdamentes Bádog 6.50 Auto Spray No. 50-Sárga Réz 21/2 Gall. 7.90 


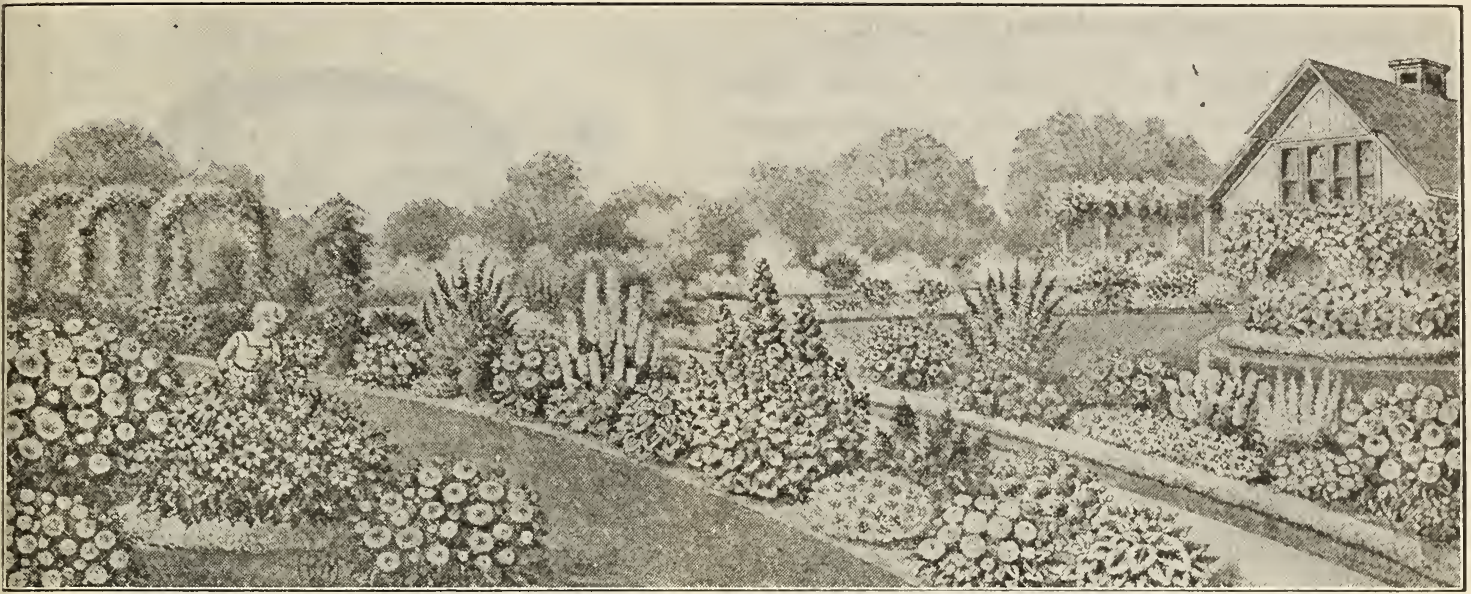

Évelö és egynyári virágokkal a legszebb fajokkal beültetett házi kert

\section{LEGGYÖNYÖRÜBB EGYNYÁRI ÉS ÉVELÓ VIRÁGMAGVAK ÓRIÁSI VÁLASZTÉKBAN.}

Csak egy szál virágot, de ha időnk és helyünk megengedi, ültessünk igen sok virágot. Semmi más lelkünket nemesitőbb munkával nem foglalkozhatunk, mint virágtenyésztéssel. Mennyivel jobban érzi magát mindenki, ha otthona, lakása körül szép és kedves virágokat lát diszleni; ha szép nyári reggeleken, napközben, vagy mindennapi foglalkozása után azokat elgyönyörködve szemlélheti. Az alábbi virágmag gyüjteményünk csakis még mindenki által a szülőhazánkból ismert legszebb és legkedvesebb virágok nemeit tartalmazza. Virágbarátok, ezeknek könnyü kezelése által, a legjobb sikereiket fogják elérni.
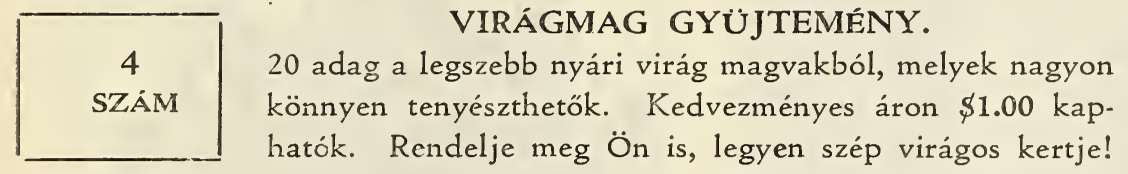

Husz adag
legszebb
virágmag
$\$ 1.00$

1 adag Árvácska, vegyes

10c 1 adag Mályvarózsa, vegyes

$10 \mathrm{c}$

1 adag Balzsamina, vegyes

$10 c$

1 adag Phlox, vegyes

$10 c$

1 adag Bársonyvirág, vegyes

10c 1 adag Petunia, vegyes

$10 c$

1 adag Buzavirág, vegyes

$10 c$

1 adag Portulakka, vegyes

$10 \mathrm{c}$

1 adag Borsó, szagos

10c 1 adag Nyári Cédrus, vegyes

$10 c$

1 adag Cosmos, vegyes

$10 c$

$10 \mathrm{c}$

1 adag Rezeda, vegyes

$10 \mathrm{c}$

1 adag Calendula, vegyes

$10 \mathrm{c}$

1 adag Öszirózsa, vegyes

$10 \mathrm{c}$

1 adag Disz Mák, vegyes

$10 \mathrm{c}$

1 adag Tátika, vegyes

$10 \mathrm{c}$

1 adag Gillardia, vegyes

1 adag Zinia, vegyes

$10 c$

1 adag Kakastaraj, vegyes

$10 \mathrm{c}$

1 adag Kéknefelejts, vegyes

$10 c$

Adagonként az árjegyzéki ára

$\$ 2.00$ 


\section{Árvácska-Viola Tricolor.}

TENYÉSZTÉSE: Tavasszal földdel töltött ládikákba (box-ba), vagy ki a szabadba ágyacskákba vessük a magot és csak nagyon kevés földet használjunk takaróul. Ha már megerősödtek a palánták, ágyakba vagy szegélyeknek kiültethetők, hogy azonban minél tökéletesebb palántákat nyerjünk, a magot augusztusban vessük el $s$ a megerősödött növényeket októberben ültessük állandó helyükre; télen át védjük kevés szalmatakarással. Az igy tenyésztett növények már kora tavaszon gyönyörü szinezetü virágokban gyönyörködtetnek bennünket.

ÁRVÁCSKA, ÓRIÁSI VIRÁGU, VEGYES. Ezen faj kertjeink legnagyobb disze, kivált tavaszi csoportokban hálásan virit. Kék, sárga, fekete, fehér és tarka szinek vegyesitve. Adag 10c.

Ha városában nincs express hivatal (Express Office), nagyon kérjük a legközelebbi város nevét adni, ahol van ezen hivatalok egyike.

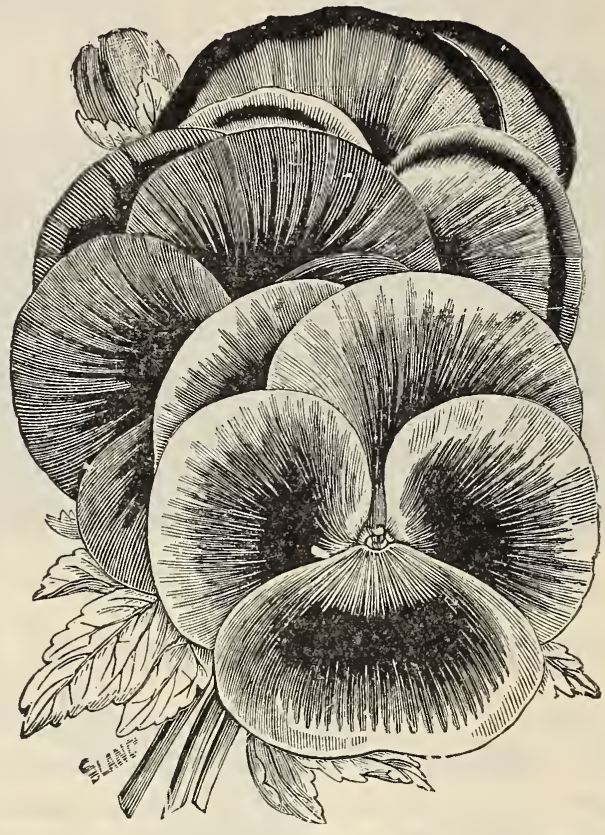

Arvácska

Bájvirág.

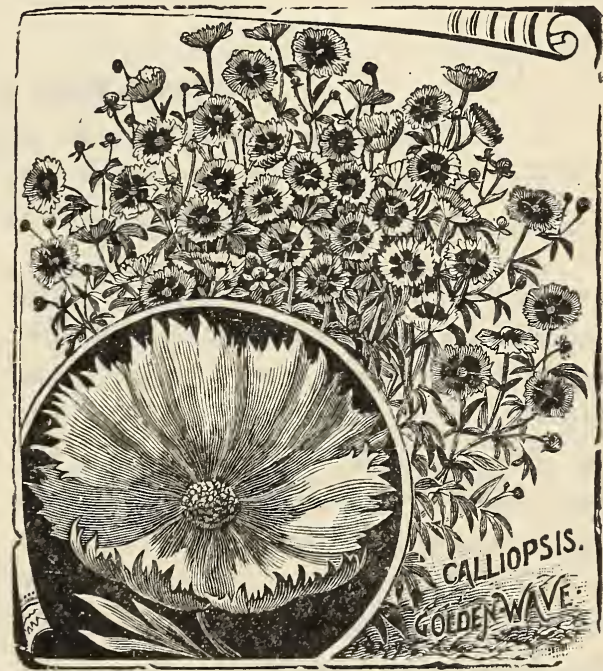

TENYÉSZTÉSE: Vetendő március-áprilisban ki a szabadba. Virágzik juniustól késő őszig.

CALLIOPSIS vagy BÁJVIRÁG, KEVERT. Kitünő, bájos virágcsokrok készitéséhez. Sárga és sárga-piros tarka virágokkal. Adag 10c. 


\section{Bársonyvirág-Tagetes.}

TENYÉSZTÉSE: Vetendő kora tavaszon ládikákba, vagy később ki a szabadba, védettebb helyre. A palánták széjjel ültetendők.

BÁRSONYVIRÁG vagy BÁRSONYKA. Telt virágu magas fajok, minden szinbőll vegyitve. Igen diszlik mindenhol, csak az árnyékos helyet nem szereti. Adag 10c.

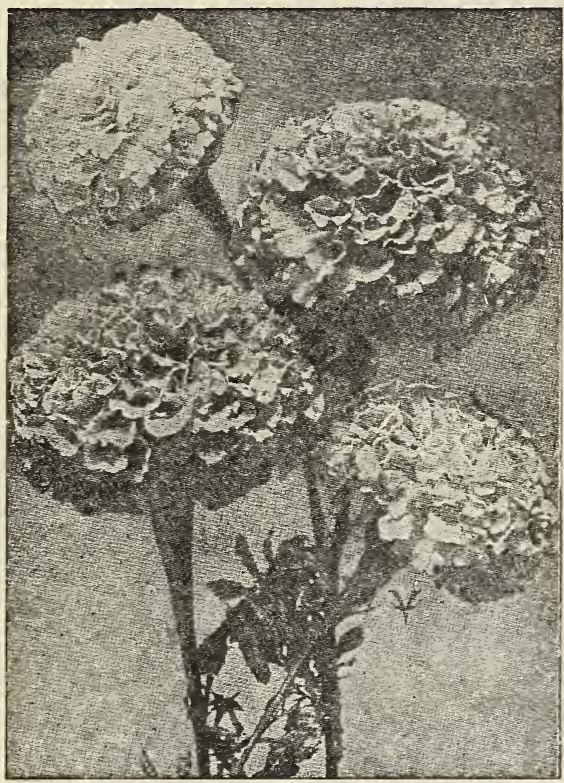

Bársonyvirág

\section{Buzavirág-Centaurea.}

TENYÉSZTÉSE: Vetendő április-májusban a szabadban. Minden kerti földben diszlik. Virág. zik szeptemberig.

BUZAVIRÁG. Kevert. Kék, fehér, rózsa és lila szinekben. Hálás szép virág, késő őszig virágzik. Adag 10c.

\section{Chrysanthemum.}

TENYÉSZTÉSE: Szabadban márciustól májusig vetendő, cserepekben vagy ládikákban, ahonnan a palánták kiültetendők.

CHRYSANTHEMUM VEGYES. Szép, teljes vegyes virágokkal, melyek csok rok kötéséhez kiválóan alkalmasak. Nincs olyan virág, amely jobban megajándékozza a tenyésztôt, mint ez, a palánták nagyok és bokrosak és teljesen tömve vannak $11 / 2 \mathrm{col}$ átmérő nagyságu gyönyörü virágokkal. Adag 15c.

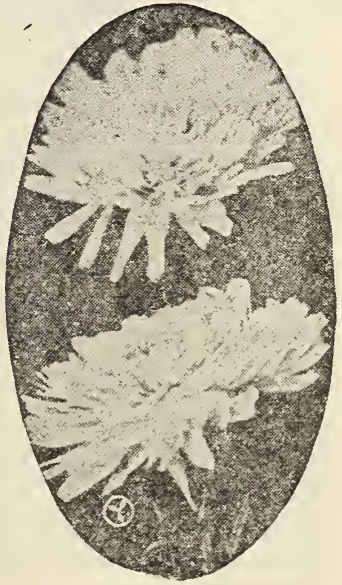

Chysanthemum
Szagos Borsó-Lathyrus Odorata.

TENYÉSZTÉSE: Vetése áprilisban a szabadban, egyenesen állandó helyére. Kikelése után rözsét rakunk melléje, hogy azon felkuszhassanak.

SZAGOS BORSÓ vagy SZAGOS BÜKKÖNY. Gyönyörü kerti virág. Jó illatával és virágjainak gyönyörü változatával ma már elsőrendü diszvirág. Különböző szinekben. Virágzik késő őszig. Adag $10 \mathrm{c}$.
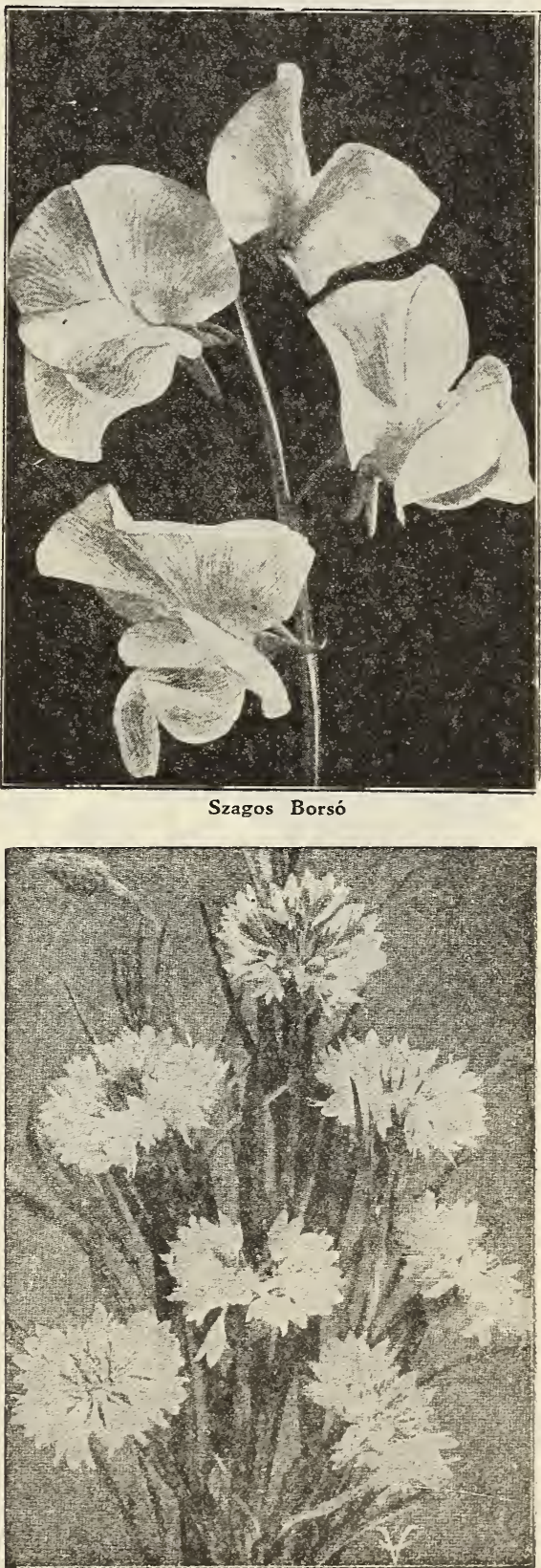

Buzaviråg 

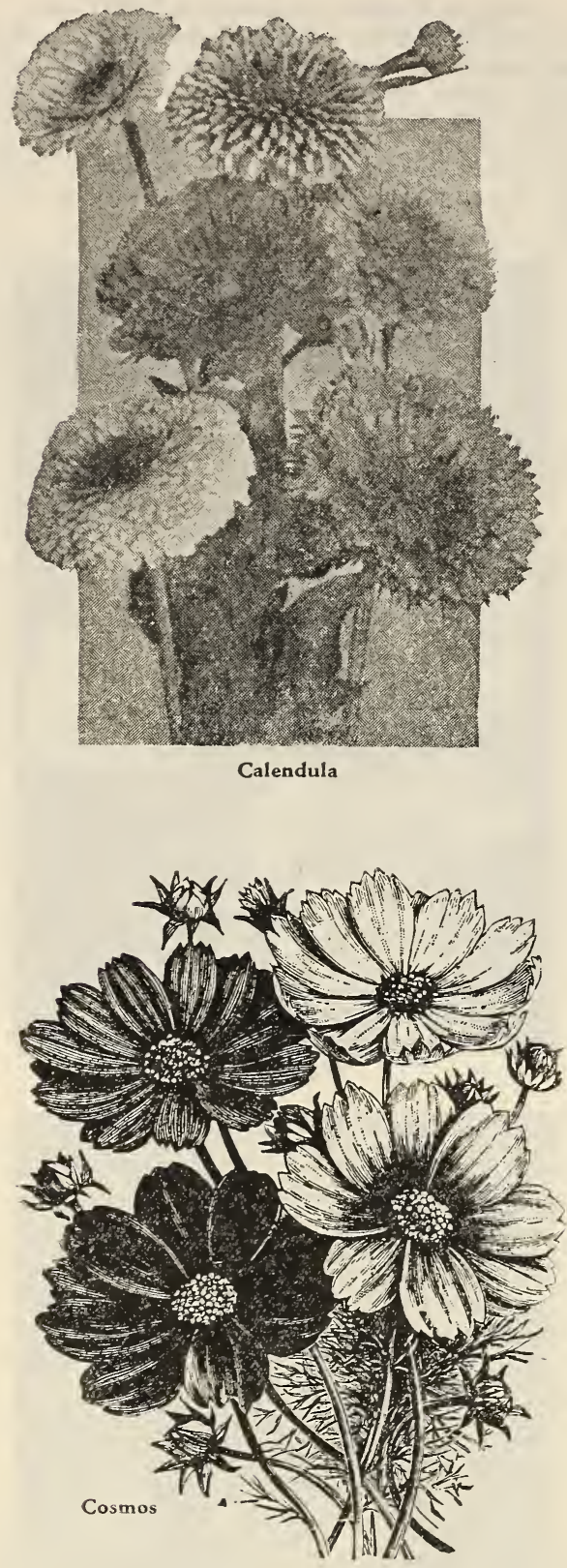

\section{Cosmos.}

TENYÉSZTÉSE: Kora tavasszal ládikákba vetendő a mag, vagy később ki a szabadban ágyacskákban, ahonnan a palánłák kiültetendök.

COSMOS VEGYES. Nagy virágu, bájos, ked velt kerti virág, hosszu szárai miatt a kötészethez igen alkalmas, a palánták kifejlődnek 6 láb magasra és nagyon ágosak, levelei csipkések, ami nagyon diszessé teszi. Adag 10c.

\section{Calendula.}

TENYÉSZTÉSE. Szabadban vetendő, minden kerti földben diszlik, virágzik egész októberig.

CALENDULA KEVERT. Teljes narancssárga virágu, magassága 12 col, egész a fagyok beálltáig folyton virágzik, ugy ágyakban, mint szegélyeknek kitünő. Csokrckhoz pedig nagyon be cses. Adag 15c.

\section{Diszdohány.}

TENYÉSZTÉSE: Vetendő március-áprilisban edénybe vagy melegágyba, később ki a szabadba. A palánták megerósödtével azok kiültetendők.

DISZDOHÁNY. Gyönyörü nagy, fehéres rózsaszinü, kellemes szagu virágokkal. Adag 10c.

\section{Diszmák-Papaver.}

TENYÉSZTÉSE: Vessük a magot ki a sza. badba, állandó helyére április vagy májusban. Kövér, porhanyós földet szeret.

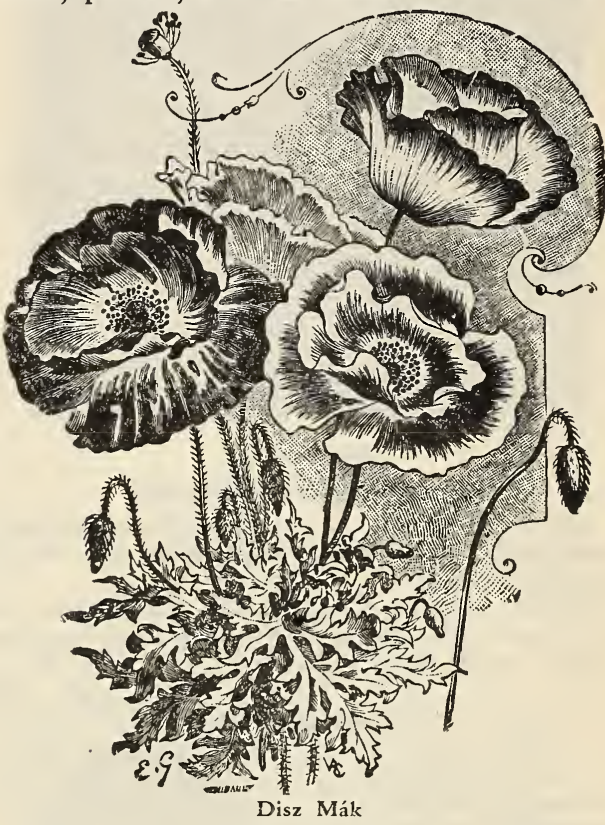

DISZ MÁK VEGYES. Remek egyszerü virágu pipacsok keveréke a leggyönyörübb hófehér, sárga, tüzpiros, tarka és rózsaszinekben. Igen kedves nyári virág csoportokban és virágágyakban. Remek csokrokat alkot. Adag 10c.

\section{Égő Szerelem.}

TENYÉSZTÉSE: Április-májusban vetendő a szabadba. Gyökere egy helyben hagyva, több évig elél. Virágzik juliustól szeptemberig.

ÉGö SZERELEM. Évekig eltartó, gyökerei a legszebb tüzpiros, csomókban fejlődő virágot produkálnak. Virágja állása nagyon hasonlit a török szekfühöz, a különbség köztük az, hogy az Égő Szerelem csak egy szinben van és pedig a legremekebb tüzpiros szinben. Ezen gyönyörü virág az összes virágkertekből elmaradhatatlan. Adag 15c. 


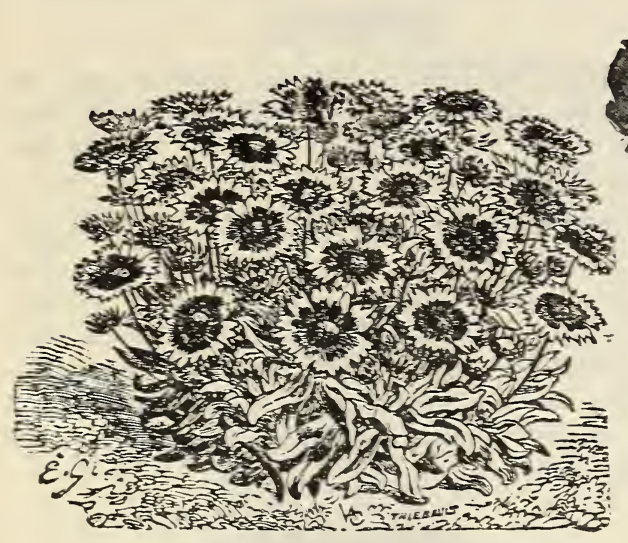

Gaillardia

TENYÉSZTÉSE: Vessük a magot állandó he. lyére áprilisban. Gyökerei több évig elélnsk.

GAILLARDIA VEGYES. A legszebben és leg dusabban virágzó évelők közé tartoznak. Arany. sárga virágai gyönyö:ü pirossal tarkázva, kitünö csokrokat alkotnak. Adag 10c.

\section{Györgyina egynyári.}

TENYÉSZTÉSE. Vessük a magot május hónap elején szabadba csoportba, 4-6 szem magot egy csoportba, 2 láb távolságban. A mag kikelte után 3 szálig kiritkitjuk öket.

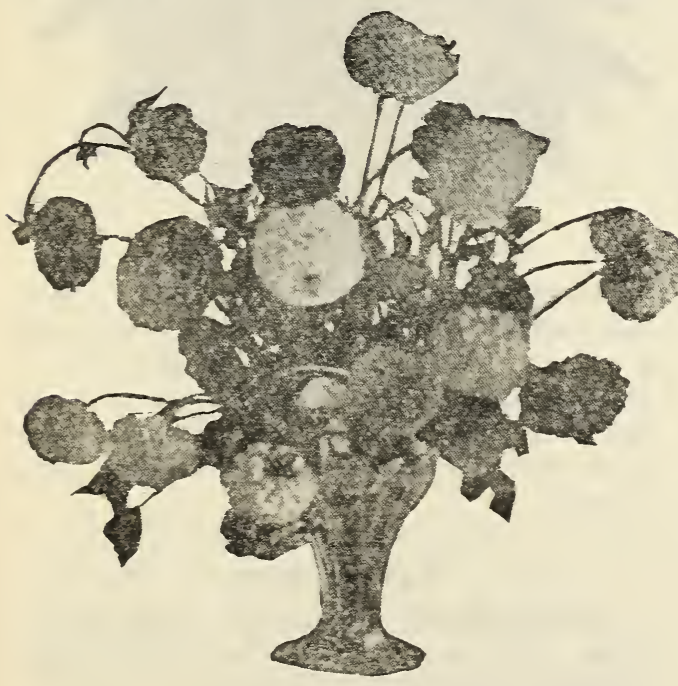

Gyorgyina Egynyári

GYÖRGYINA EGYNYÁRI. Ezen gyönyörü györgyina ujdonság párját ritkitja az összes virágok között. Maơról kell vetni és augusztus elejétöl fogva egésź a fagy beálltáig szakadatla. nul hozza a legremekebb szinü, rózsához hasonló óriási virágokat. Teljes virágu, vegyes szi. nekben. Adag 15c.

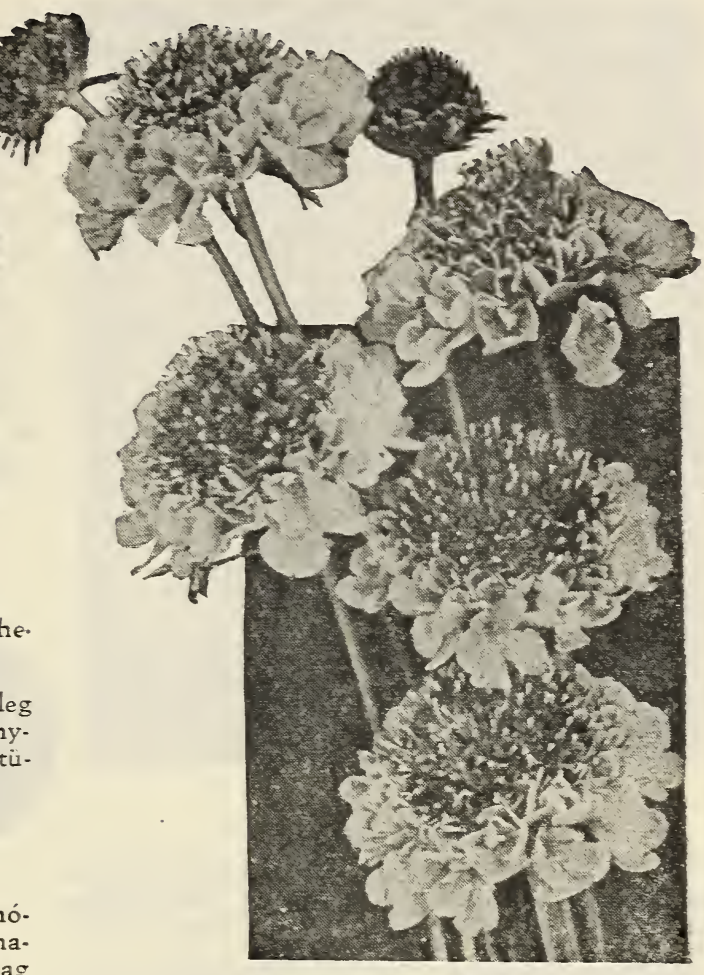

Hajnali Menyasszony

\section{Hajnali Menyasszony.}

TENYÉSZTÉSE: Vessük a magot a szabadba április utólján. A növények megritkitandók. ha már elég erösek és szét lehe: öket ültetni.

HAJNALI MENYASSZONY. Egyike a leg zemekebb egynyá:i virágoknak. Egész junius hó naptól hideg őszig szakadatlanul hozza a legpompásabb, több szinü virágokat, a virágokat mind hosszu szárakon hozza és ezért is pompas vágott virágot szolgál az asztalra, vizben eláll 10 napig, hogy meg nem hervad, tehát egy virág kert sem teljes ezen kitünő virágfaj nélkül, kivált azoké, akik kedvelik a vágott virágot a házban. Adag 10c.

HELIOPSIS (Narancs Virág). Egyike a legszebb télálló virázoknak, a palánták kifejlödnek 3-4 láb magasra és nagyon korán tavasszal meq kezdik a virágzást és egész hideg őszig folyton virágzanak. A virágja szine sötét arany-sárga, nagysága 3 col átmérö és a legelsőbbrendü vágott virágot szol-zálja. Ezen virágot ültessük oly helyre, hol egész télen át benn maradhat, mivel teljesen télálló és minden tavaszon ujra megkezdi a virágzást. Adag 15c. 


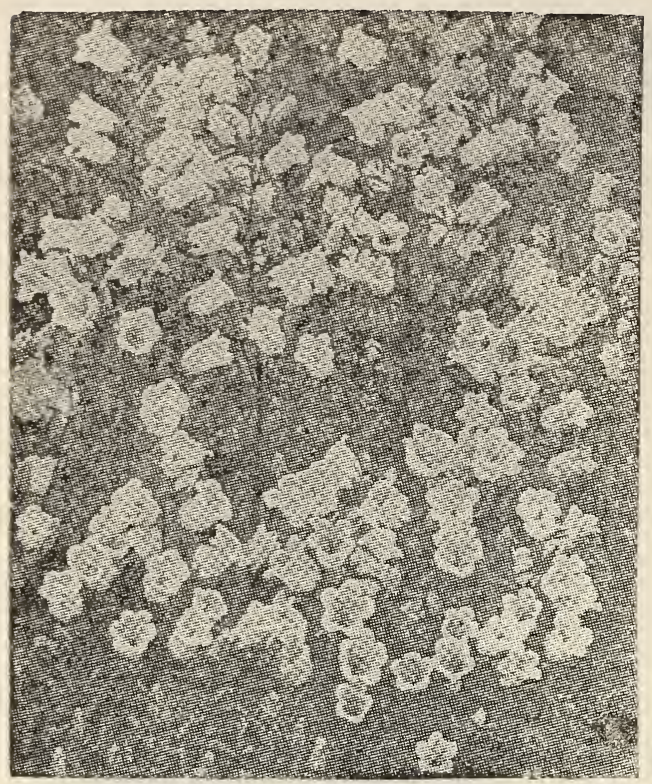

\section{Harangvirág.}

TENYÉSZTÉSE: Vethetjük a magot áprilisban a szabad földbe. A növények megritkitan. dók és széjjel ültetendök, ha már elég erősek. Évelö virág.

HARANGVIRÁG. Remek égszinkék virágu kerti virág. Gyökerei több évig elélnek. Adag

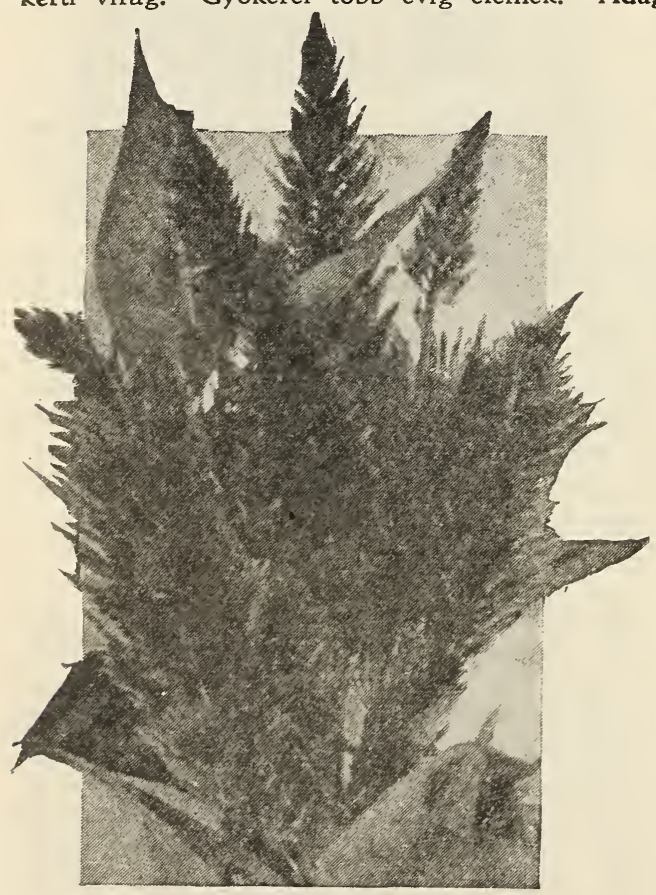

Bóbitás Kakastaréj

\section{Kakastaréj.}

TENYÉSZTÉSE: Vetendő március vagy áp. rilisban melegágyba vagy ládikába, amely szintén napos, meleg helyen tartandó. Junius elején kiültetendö.

BÓBITÁS KAKASTARÉJ. Szép magasra növő virág. Virágja állása hasonlit a strucc ma. dár tollához. Egy-egy virág hónapokig gyönyörü szinesen megmarad, mert ahogy a virág alulról mulóban van, a felső vége folytonosan fejlődik és tovább virágzik. 2-3 láb magasra nő és hosszu sorokba vetve bámulatba ejti a néző közönséget. Adag 10c.

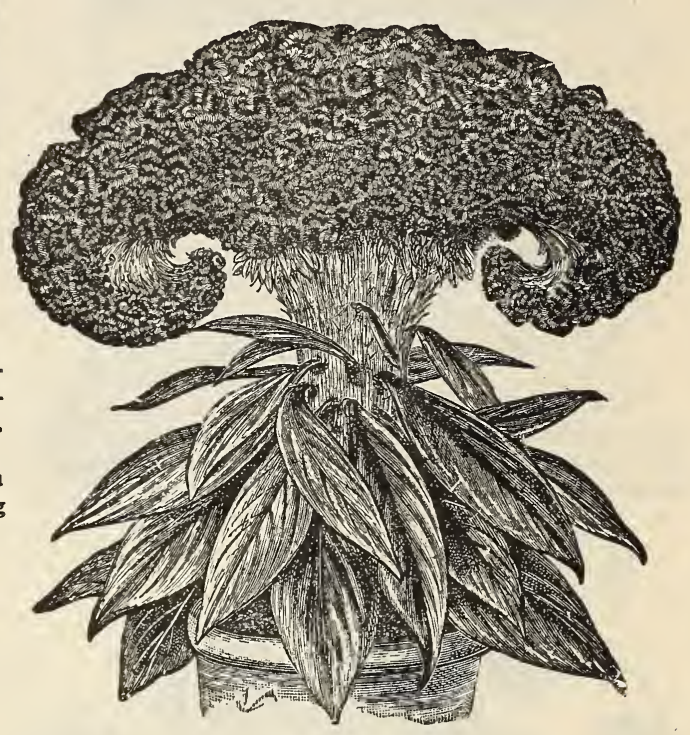

Törpe Kakastaréj

TÖRPE KAKASTARÉJ. Alacsony növésü, igen kedvelt kerti disznövény, pompás szinekben, a palánták 8-10 col magasak és többször a virágok kifejlődnek 12 col átmérö nagyságra, ugy ágyakban, mint szegélynek kitünő, virágja szárogatva, télen diszitésekre nagyon alkalmas. Adag 10 cent.

\section{Kéknefelejts.}

TENYÉSZTÉSE: Márciusban ládikába ve. tendö, amely napos, meleg, helyre helyezendö. Finomul elkészitett földet kiván.

KÉKNEFELEJTS. Szegélyzetekben, valamint cserepekben és csoportokban igen hatásosak. Egyszer kell csak magról vetni és azután ugy kell szaporitani, hogy a palántákat szét kell szed. ni. Teljesen télálló és tavasztól hideg osséig virágzik. Virágja szine mély kék. Adag 10c. 


\section{Mályvarózsa.}

TENYÉSZTÉSE: Vessük a magot ki a szabadba április vagy májusban, könnyü, finoman elkészitett homokos földbe. A mag kikeltével és ha a palánták elég erösek, széjjel ültetendők.

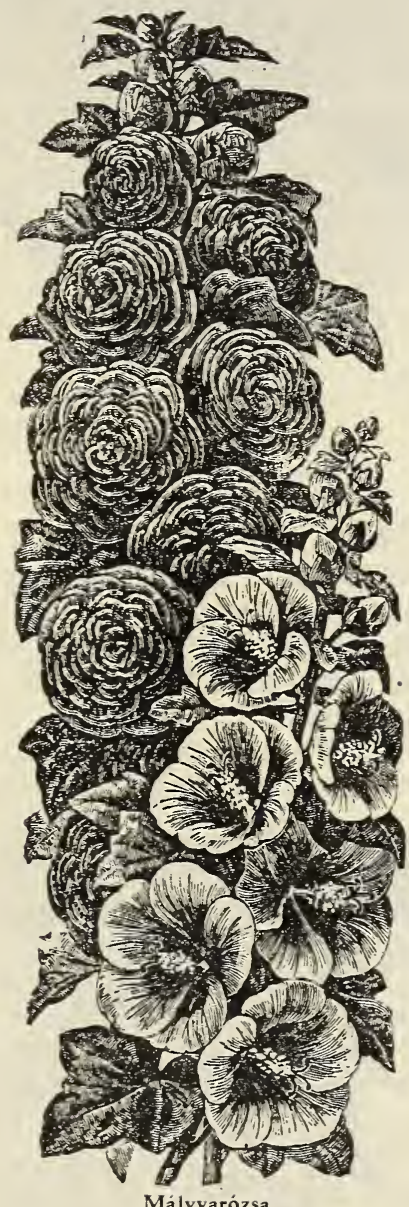

MÁLYVARÓZSA VEGYES. A mályvarózsák nagyszerü és festői hatásu disznövények. Virágbőségük gyönyörü látványt ryujt. Gyönyörü hófehér, piros, sárga, rózsaszin, stb. vegyitve. Adag 10c.

\section{Nyári Cédrus.}

Ezen gyönyörü ujdonság tökéletesen hasonlit a rendes cédrus fenyőhöz. Növése gyönyörü szép piramis alaku, magassága eléri a három lá. bat, nyáron remek üdezöld, ősszel pedig maja. nem teljesen vörös. Adag 10c.

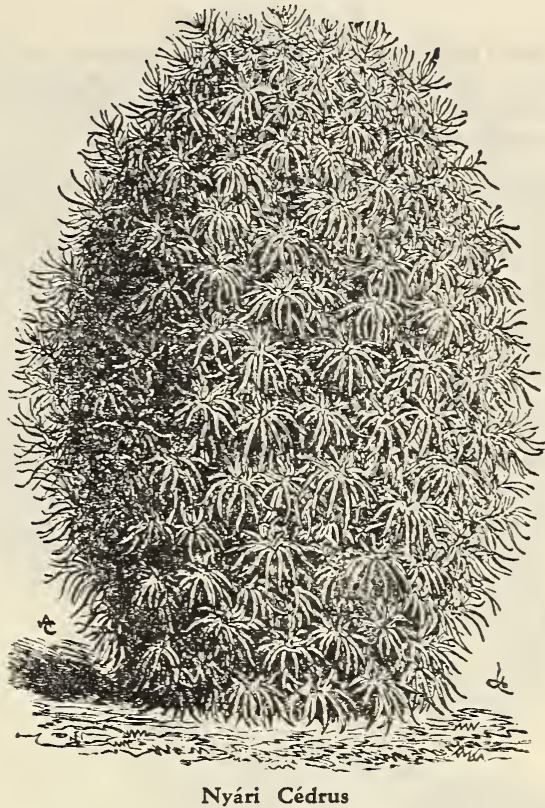

Oroszlánszáj vagy Tátika.

TENYÉSZTÉSE: Vetendő március-áprilisban vagy később, lehetőleg edényekbe, mert a magva nagyon finom. Májusban a virágpalán. ták kiültetendők.

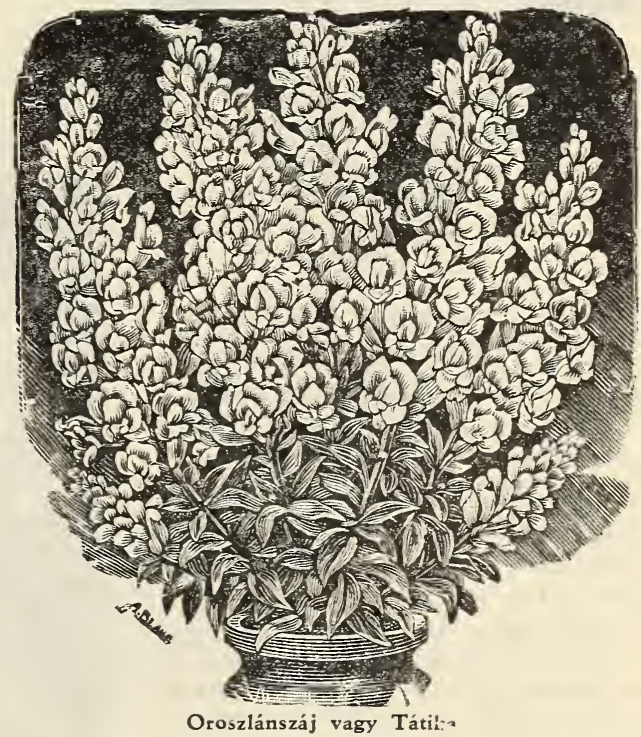

OROSZLÁNSZÁJ KEVERT. Az oroszlán. száj rendkivül dus és szép virágzata folytán közismert. Soká nyiló virága a virágkötészethez kitünő.

Rózsaszin, adag _

Piros, adag $10 c$

Fehér, adag _________ $10 c$

Sárga, adag ________________ $10 c$

Vegyes szinekben, adag $10 \mathrm{c}$ 


\section{Öszi Rózsa.}

TENYÉSZTÉSE: A mag márciustól májusig vetendö jó kövér, homokos földbe. A növények megerösödtével májusban állandó helyükre ki. ültethetők.

ÖSZI RÓZSA, VEGYES. Nem létezik virág, amely oly népszerüségnek örvendene, mint az őszi rózsa. Magkeverékünk csakis a legjobb fajokat tartalmazza, amelyek minden tekintetben a legnemesebb alaku és szinü virágokat hozzák a legremekebb szinkeverékben.

Korai Királyné Fehér - 15c

Korai Királyné Sötét Kék _.____ 15c

Korai Királyné Vörös _.__ $15 \mathrm{c}$

Korai Királyné Sötét Rózsaszin _-____- 15 c

Korai Királyné Világos Rózsaszin _-_ 15c

Korai Királyné Ibolyakék … 15c

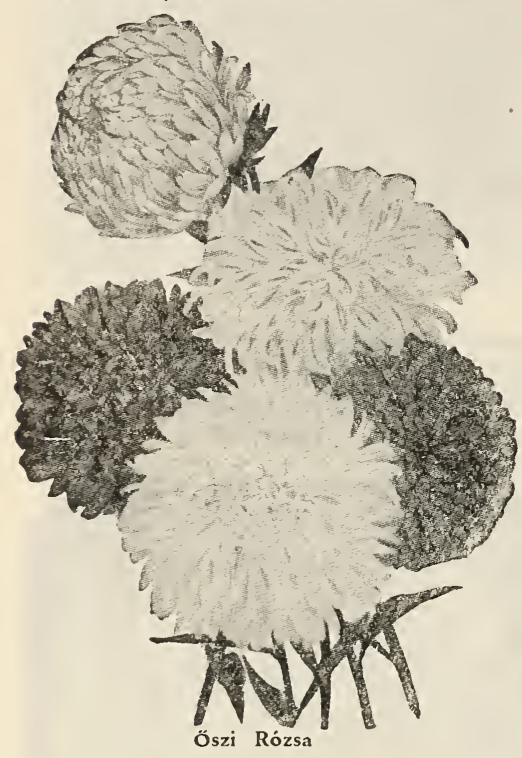

Petunia.

TENYÉSZTÉSE: A mag edénybe vagy ládikába vetendö, a melyben a föld finomul legyen elkészitve. Vetése március vagy április. Elvetése után az edény vagy ládika napos, meleg helyen tartandó. A palánták megerősödése után széjjel ültetendők.

PETUNIA VEGYES. -- Az egyszerü virágu petuniák a legszebb keitı virágaink egyike. A szinek sokasága és ragyogása, a virágok szépsége és illata a Petuniának elsőrangu helyet adnak. Adag 10c.

PETUNIA FODROSVIRÁGU. Gyönyörü fodros virágu ujdonság, a legremekebb brilliant szinváltozatban, virág nagysága néha 3 incs átméröben és junius hónaptól egész a fagy beálltáig szakadatlanul virágzik. Vegyes szinekben. Adag 20c.

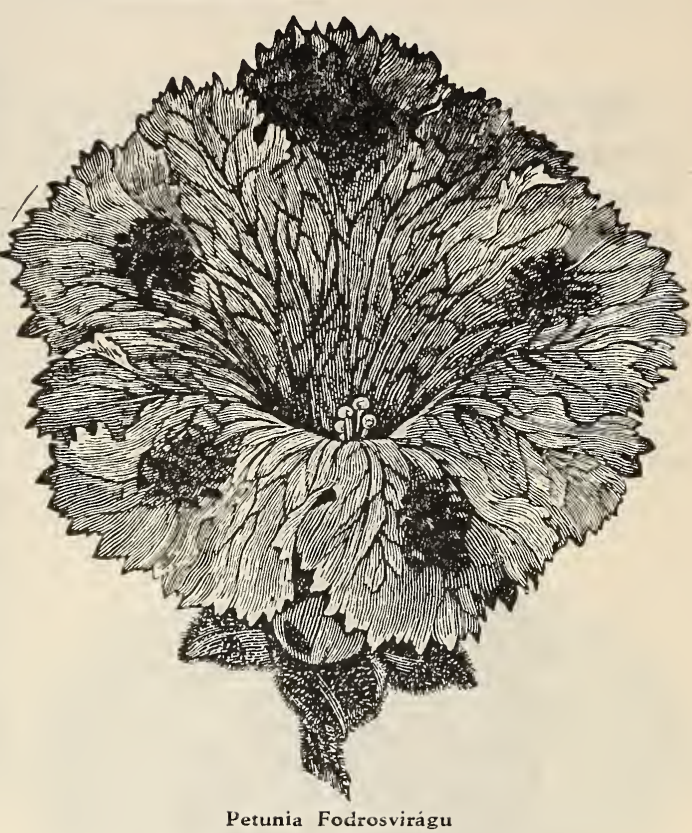

Phlox vagy Lángvirág.

TENYÉSZTÉSE: Vessük a magot korán tavaszon melegágyban, vagy később ki a sza. badba ágyacskákba. A palánták, ha máx elég erősek, a szabadba kiültethetők.

PHLOX VEGYES. Szépség és virág tc. kintetében felülmulhatatlan. Bámulatba ejtő kitartással virit az őszi fagyig. Adag 10c.

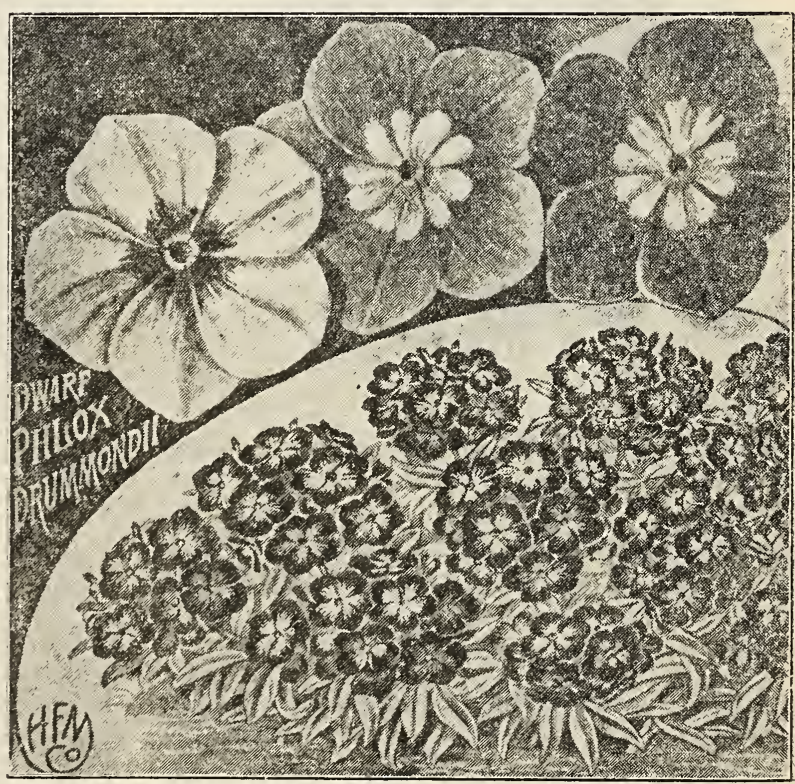

Phlox vagy Lángvirág 


\section{Pókvirág.}

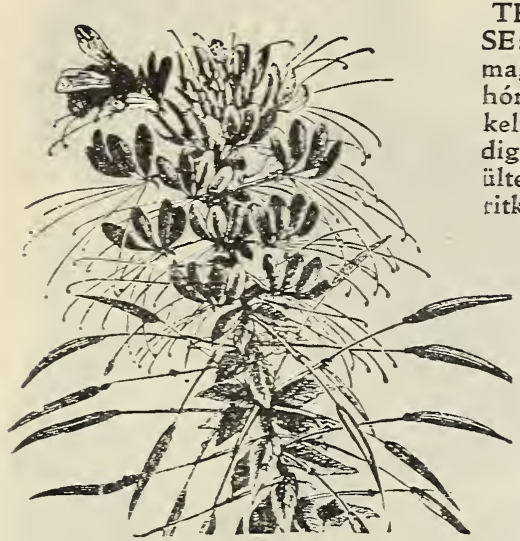

Pókvirág : Vessük a magot május hónapban, $k_{i}$ kelte után pedig vagy szétültetjük, vagy itkitjuk. PÓKVI. RÁG. Ezen $\mathrm{s}$ a já tságo: kinézésü vi rág nagyon szép és al. kalmas oly helyekre, a hol 3..4 láb magasra fel. nőhet. - A fenti elne. vezést azért kapta, hogy tökéletesen hasonlit az eleven pókhoz. Vegyes szinekben... Adag 10c.

\section{Portulaka.}

TENYÉSZTÉSE: Vessük •a magot május hónapban szabadba, állandó helyére és kikel. te uán kissé kiritkitjuk.

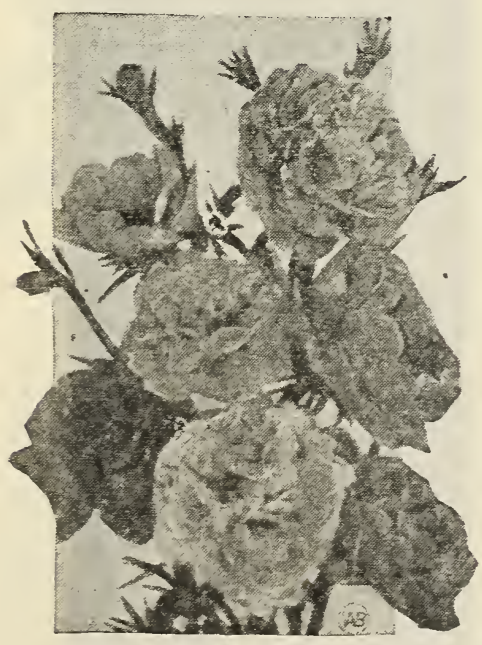

Portulaka

PORTULAKA. Rendkivül igénytelen és igen hálásan viritó növény. A legforróbb szárazságban is igen szépen diszlik és talaj tekintetében se válogatós. $\mathrm{Az}$ árnyékos helyet nem kedveli. Vegyes szinekben. Adag, $10 \mathrm{c}$.

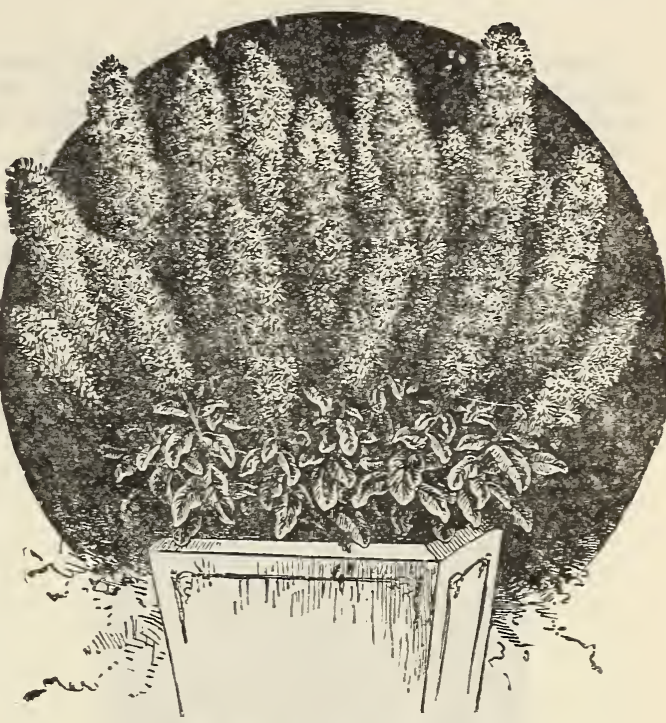

Rezeda mint Cserépvirág

\section{Rezeda.}

REZEDA NAGYVIRÁGU. Legismertebb és leg. kedveltebb virágaink egyike, telve tömören egymást érő virágokkal. Cserépben is tenyészthetők. Adag $10 \mathrm{c}$.

\section{Salpiglossis vagy Trombitavirág.}

TENYÉSZTÉSE: Március, áprilisban vetendő homokos földdel telitett cserepekbe vagy ládikákba és májusban kiültetendö.

SALPIGLOSSIS. Gyönyörü bársonyos virágu szineḱben. Juliustól öszig folyton virit. Adag 10c.

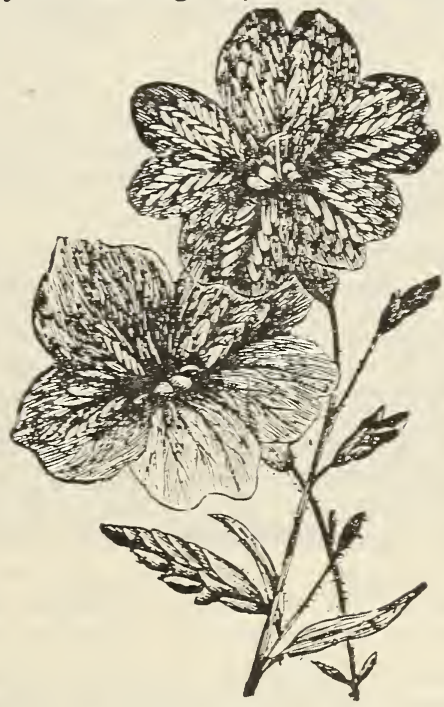

Salpiglossis vagy Trombitavirág 


\section{Salvia.}

TENYÉSZTÉSE: A magot melegágyba vagy edénybe vetjük, amit meleg, napos helyen es nedvesen tartunk. Május végén kiplántázzuk a szabadba.

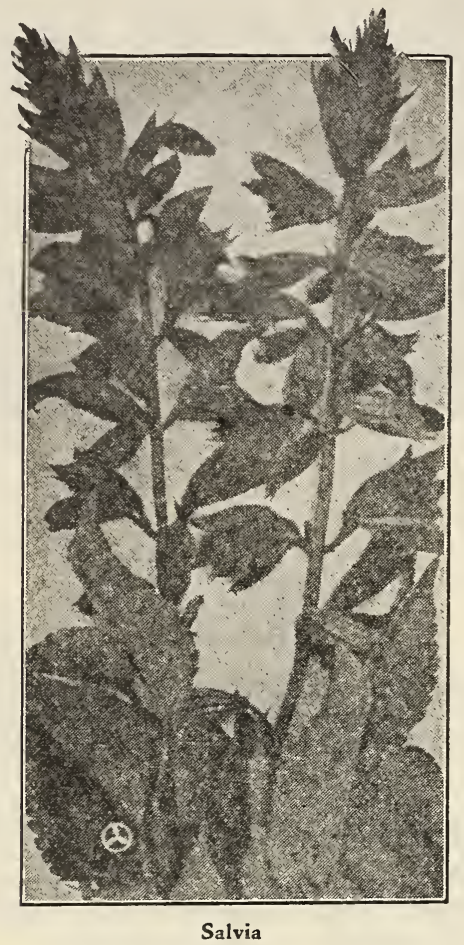

SALVIA SPLENDENS. Gyönyörü virágnövény, ragyogó tüzpiros virágokkal. Csoportoß ban nagyon szép és cserepekbe tenyésztve is alkalmas. Adag 10c.

\section{Szalmavirág.}

TENYÉSZTÉSE: Március-áprilisban vagy ke. sőbb vetjük a magot. Május végével kiültetjük a palántákat jó kerti földbe.

SZALMA VIRÁG. Egyike a legjobb tartós virágoknak. Nyári és téli csokrokban nélkülözhetetlen. Télire szárogatva vágjuk le a virágot hosszu szárakkal, amikor háromnegyed része ki van nyilva, szedjük le a levelét és kössük cso. mókba, akasszuk fel sötét, száraz helyre, fejjel iefelé, amig teljesen ki nem szárad, amikor lehe: csokrokban használni. Ezen keverék a legszebb fajokból van keverve. Adag 10c.

\section{Szarkaláb.}

TENYÉSZTÉSE: Vessük a magot tavasszal ki a szabadba, jól elkészitett, porhanyós földbe Kora nyártól öszig virit.

SZARKALẢB KEVERT. Remek szép égszinkék, rózsaszinü és fehér virágu becses kerti v1rág. Nagyon szép csokrokat alkot. Adag 10c.

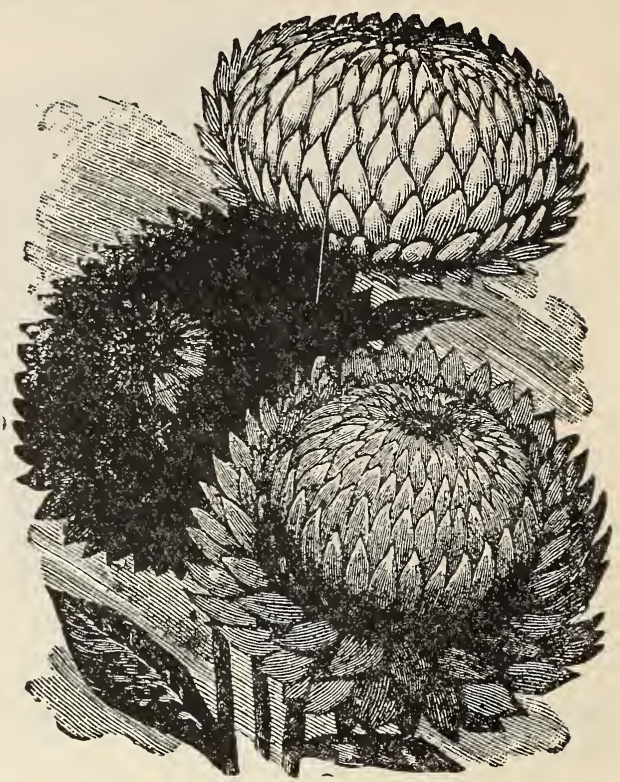

Szalmavirág

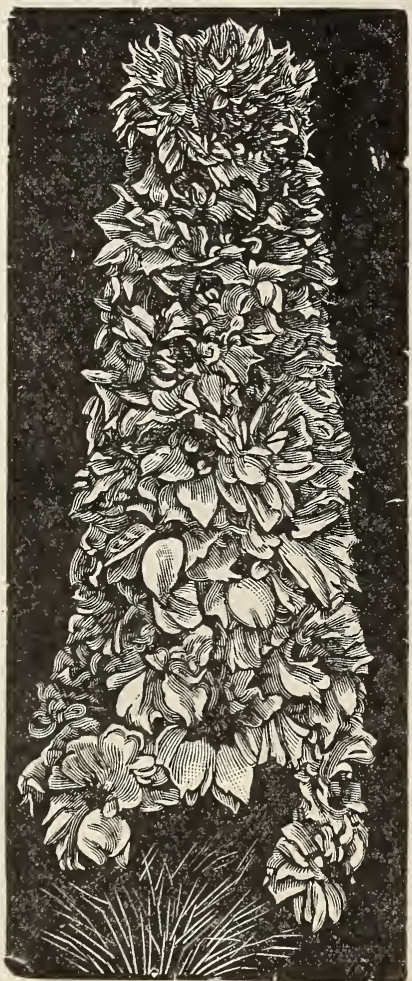

Szarkaláb 


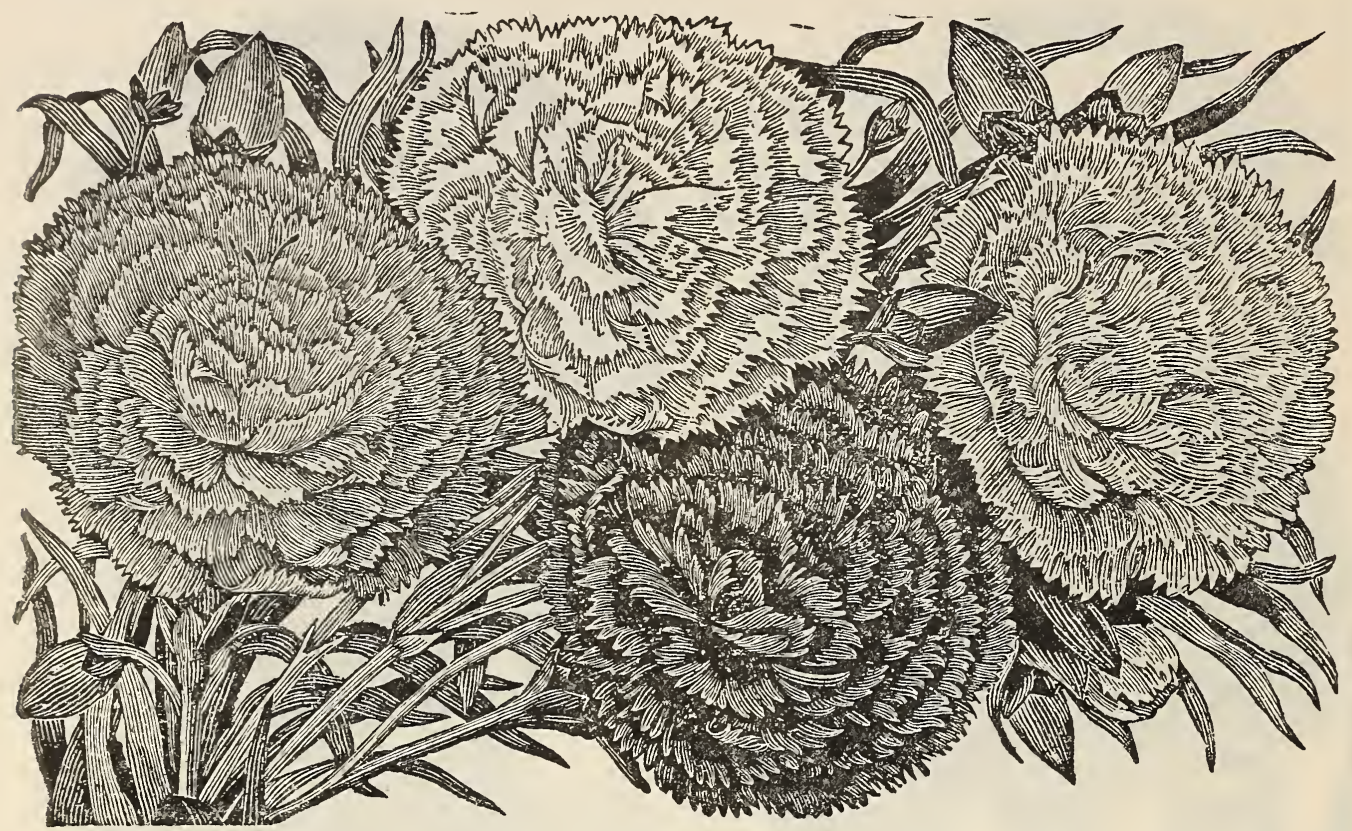

TOLLAS SZEKFÜ. Nagy virágu, a két eves szekfüfajhoz tartozó fajta, a kertben és csokor. kötéshez kitünően elhasználható. Pompás, teljes fajok, vegyesen. Adag 10c.

\section{Schizanthus (Lepke Virág).}

SCHIZANTHUS (Lepke Virág). Egyike a legszebb ès a legdiszesebbeknek az egynyári virá gok között. A palánták fölemelkednek $1-2$ láb magasságra és a mag vetése után pár hétre virag. zásba jön. Pompás többszinü, lepke alaku virág jai, amelyek teljesen takarják leveleit, bámulatosak és aki egyszer ezen Lepke Virágot tenyészti. az a kertjéből soha ki nem hagyja. Vágott virágnak elsörendü és csokorhoz felülmulhatatlan, cse. repekben beültetve télire pedig nagyon diszes házi virág. Adag 15c.

\section{Törpe Sarkantyuka.}

TENYÉSZTÉSE: Vessük a magot $\mathrm{ki}$ a sLabadba április-májusban. Különösen napos helyeî és minden kerti földben igen diszlik.

TÖRPE SARKANTYUKA, VEGYES. A tör pe sarkantyuka legjobban használható szegélyze. tek létesitésére és sokféle szineik által nagyon ha. tásosak. Cserépben való tenyésztésre is nagyon ajánlható. Vegyes szinekben. Adag 10c.

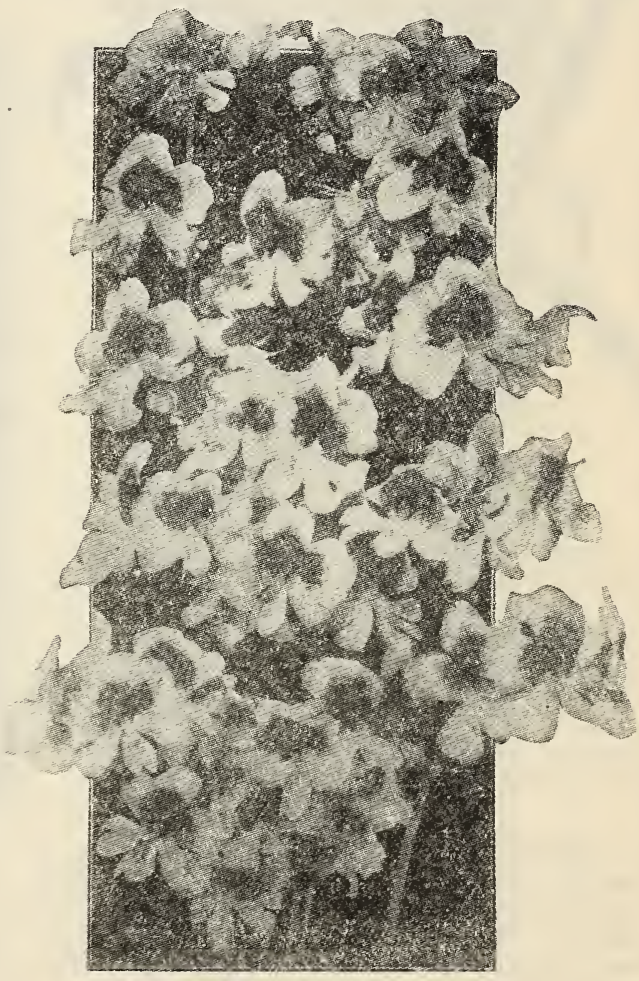

Schizanthus (Lepke Virág) 


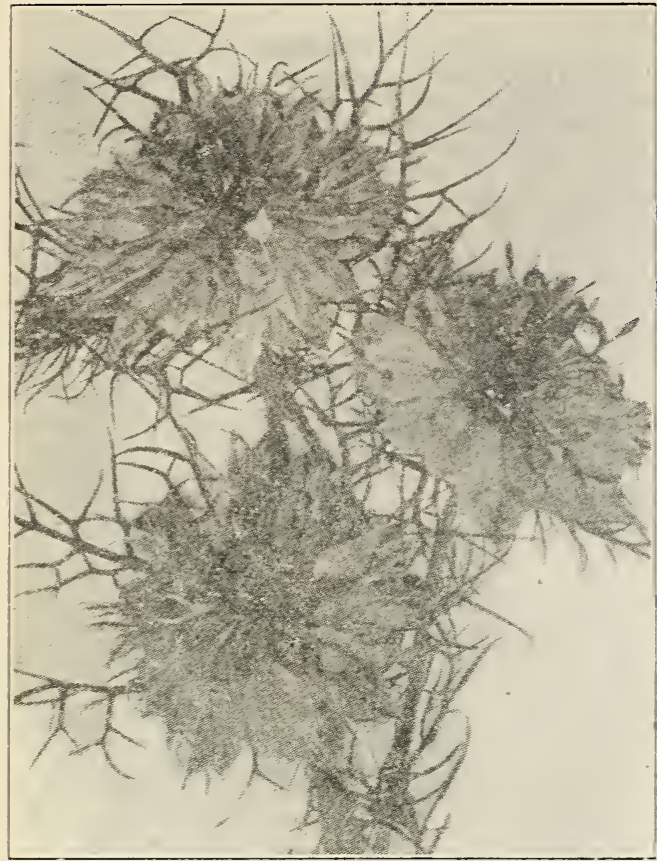

Szerelem Virág

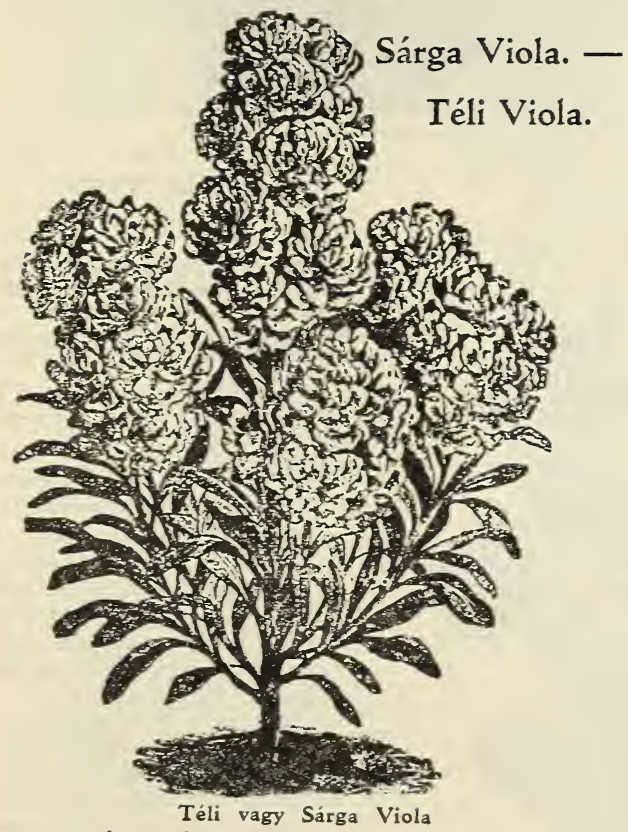

TENYÉSZTÉSE: Március vagy áprilisban a magot elvetjük a nyári violák magjához hason. lóan és a növényeket is hasonlóan kezeljük az ószig, amikor a sárga violákat fölszedjük és cse. répbe ültetjük.

TELJES SÁRGA VIOLA. Ezen téli viola faj igen nagy, gyönyörüen alakitott aranysárga arnyalattal és erős iliattal. Adag 15c.

\section{Szerelem Virág (Nigella).}

SZERELEM VIRÁG (Nigella). Egyike a leg. szebb egynyári virágoknak. Virágja szine, feher és kék, illata kitünő, a virágját hosszu szárakon hozza és a vékony, cérna alaku levelei a virágját teljesen körülveszik és minden egyes virág koszoru alakot mutat. A palánták kifejlödnek $1 \frac{1}{2}$ láb magasakra és ugy a szárazságot, mint a hideget nagyon birja. Virágjait egész hideg őszig folyton hozza, elsőrendü vágott virágot szolgál, csokrokhoz pedig nagyon becses. Adag 15c.

\section{Nyári Viola.}

TENYÉSZTÉSE: A mag elvetése legalkalmasabb idö március vagy április hava. Vessük a magot, ha lehet, homokos földdel telitett ládikákba vagy cserepekbe, amelyek napos, meleg heiyre teendök és ott nedvesen, de nem tulságosan vizesen tartandók. A növényeket átültetjük, ha mar elég erósek.

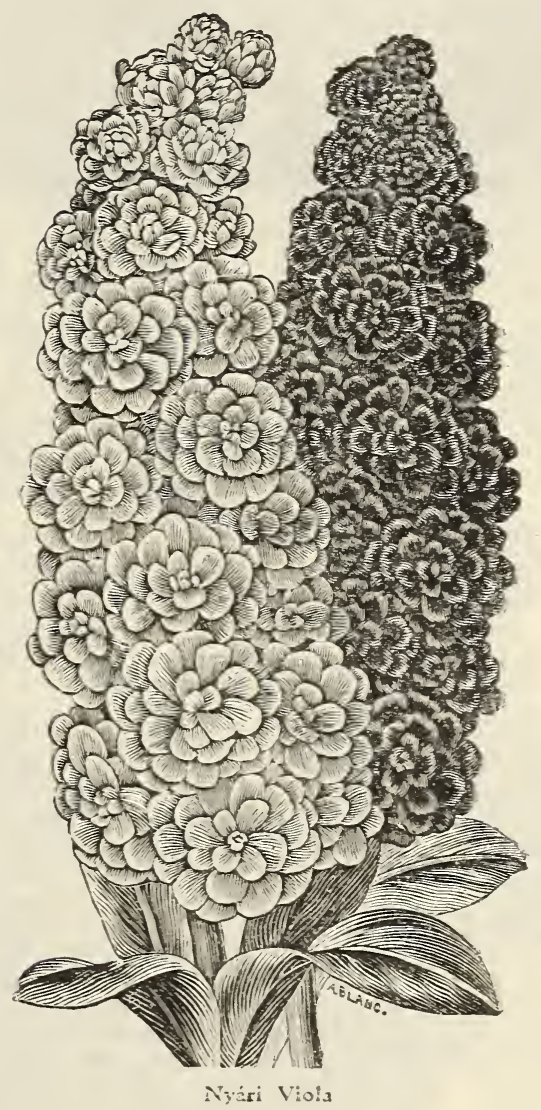

NYÁRI VIOLA. Teljesen vegyes. A legszebb fajok és legteljesebb virág szinkeveréke miatt. Dusan virágzik és illata a legkellemesebb az összes nyári violák között. Adag 15c. 


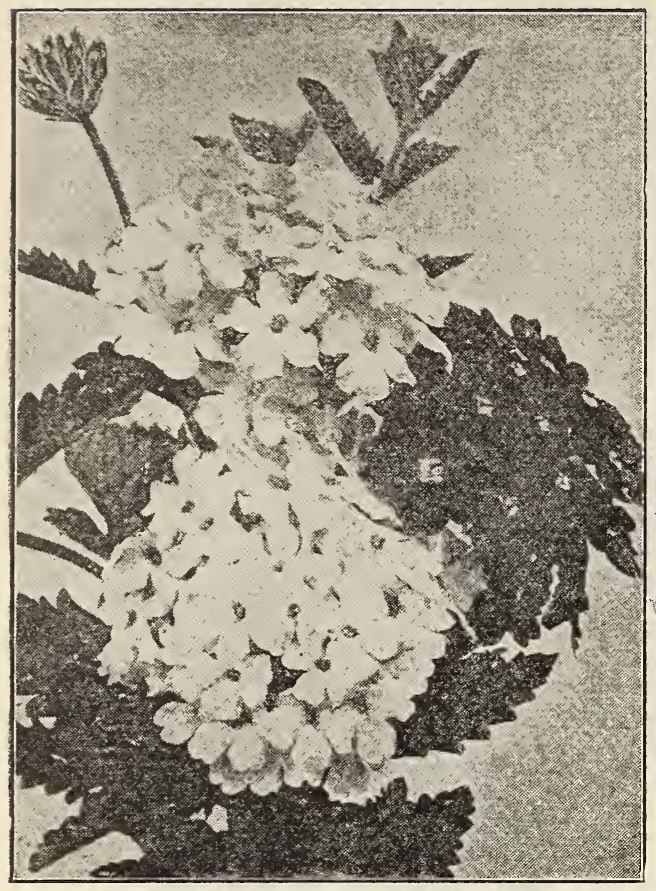

Verbena

\section{Verbena.}

TENYÉSZTÉSE: Áprilisban vagy késöbb vetjük a magot. Soká el van a földben, mig csirázik.

VERBENA VEGYES. Bájos miniatür virág, tündökló szinezetével és soká tartó virágzatával a legfinomabb nyári virágokkal első helyen all. A fagy beálltáig folyton vi. rágzik.
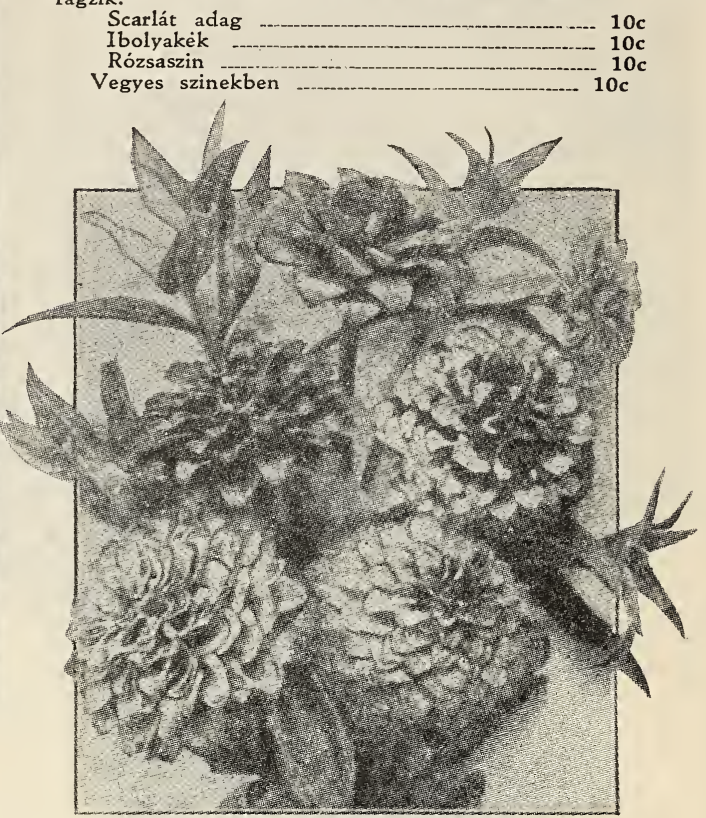

Zinnia, Györgyina virágu

\section{Zinnia vagy Rézvirág.}

TENYÉSZTÉSE: Április vagy májusban vethetjük a magot ede nyekbe, vagy ki a szabadba. Kövér, porhanyós földben a leg. jobban diszlik.

ZINNIA GYÖRGYI. NA VIRÁGU UJDUN.

SÁG. Ezen óriási virá. gu Zinnia egy legujabb válfaja a Zinniáknak. Vi . rág állása hasonlit a Györgyina virágjához. Nagyon széles, kissé gön dör virág szirmai a leg. remekebb szinekben vál. toznak. Vegyes szinek. ben. Adag 15c.

ZINNIA VEGYES. Pompás, teljes, alakra nézve a Györgyikéhez hasonló a virágja, amelyek a leggyönyörübb szi nekben fejlödnek. Virág. ágyak céljára szép alak. ja miatt nagyon alkalmas, szingazdag virágjai miatt pedig nagyon djánlható bármely célra. Adag 10c. 
Az itt felsorolt fajok a legszebb és leghálásabo futónövények. Nemcsak falakat, keritéseket, por chokat és lugasokat fut. tathatunk be, de az ab. lakokat koszorus alakbar: beszegélyezhetjük. Néhány fajta, mint a haj. nalka, sarkantyuka, ládában is tenyészthetők.

HAJNALKA VAGY FOLYÓKA. Pompás és gyors növésü kuszónövény lugasok, falak, por chok befuttatására kivá lóan alkalmas. Égszin. kék, piros, fehér, stb. virágokkal. Adag $10 \mathrm{c}$.

\section{KUSZÓ SARKAN.} TYUKA. Gyorsan fej lödő növény, könnyü kezelés, szép lombozat, foly tonos virágzás a legpom pásabb ragyogó szinek ben, a magasra nove̋ sarkantyu fajokat kedvelt kuszó növényekké tı szik. Disz keverék gyö. nyörü szinekben. Adag 10c.

COBEA. Rendkıvul gyorsan futó növény, elegáns, kecses levélzettel. Pompás falak, lugasok. és porchok befuttatására. Virágja előbb zöldes, ké. sóbb pedig lilaszinü, harang alakuak. Adag 10c.

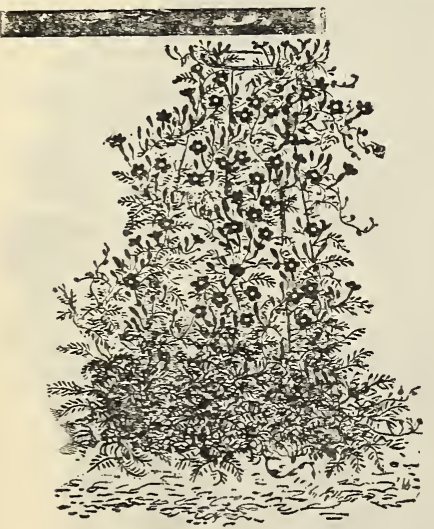

\section{KUSZÓ VIRÁGOK MAGVAI.}

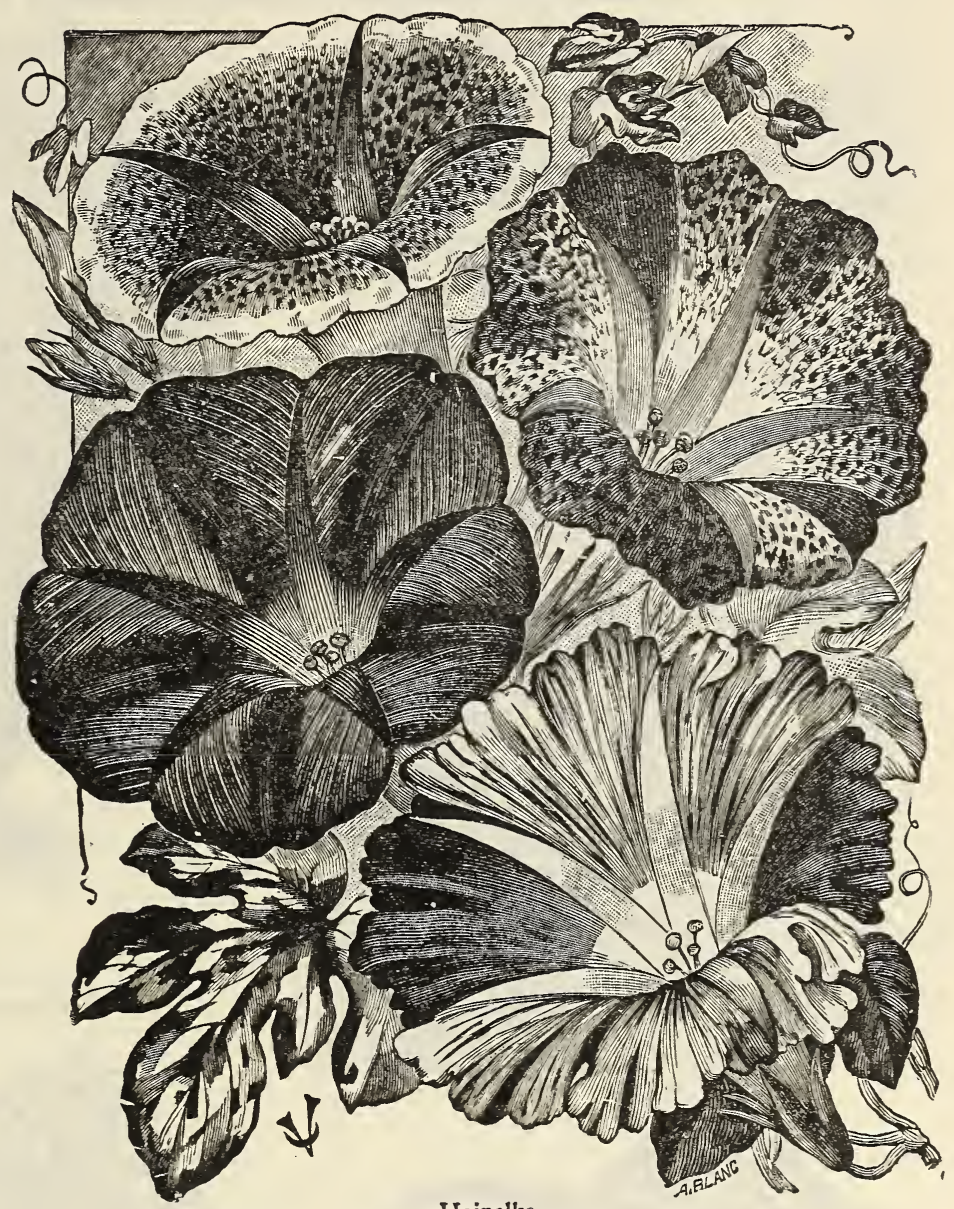

Hajnalka

JAPÁN KOM-

LÓ. Egynyári, duє lombozatu, gyorsan fejlödő felfutó növény, mely tâ. vaszkor rendeltetési helyére vetve, ó riási terjedelmet er el. Porchok, lugasok és falak befut tatására nagyon al kalmas. Levelei a legtarkábbak, amıt. elképzelni lehet.Ezüst szin, sảrga, fehér és zöld csikokkal. Adag 10c.
CARDINÁL VIRÁG, FUTÓ. A leggyönyörübb futoviragok egyike, egy náron 20-40 láb magasra is felkuszik. Nyár közepétöl egész a fagy beálltáig tele a leggyönyörübb brilliant vörös virágfürtökkel. Egyes virágja hasonlit a hajnalka virágjához és nagysága 2 incs átméröben. Levelei szintén nagyon finoman hasogatottak és magában is nagyon diszes porchok és verandák befuttatására. 1 adag $15 \mathrm{c}$.

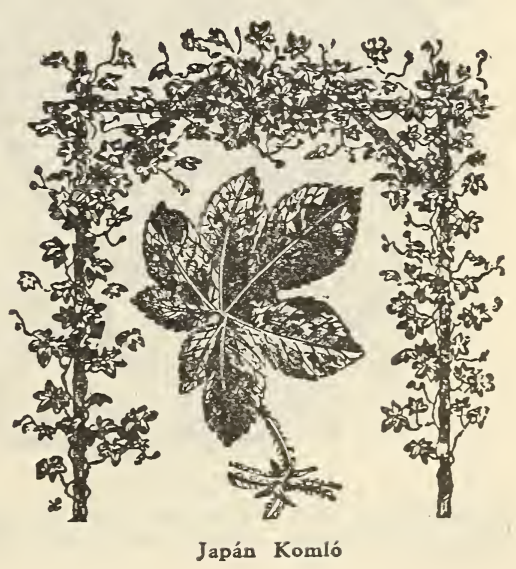




\section{KÜLÖNFÉLE SZOBA- ÉS VIRÁGNÖVÉNYEK.}

$\mathrm{Az}$ alábbi növényfajokból a legszebb példányokkal rendelkezünk.

\section{Abutilon-Virágzó juhar.}

VIRÁGZÓ JUHAR vagy JÁVOR. Nagyon hảlás szoba. növeny, növèse szabályos fa alaku ès ágai meg is fásulnak, jo kezelès mellett egész éven àt virágzik, virágja szine négy szinben váltakozik. Rózsaszin, sárga, fehér és bordó piros. Bármely szin. 1 darab 25c, 10 darab \$2.25.

TARKA IEVELƯ VIRÁGZÓ JUHAR. Levele fehér zöld csikokkal gyönyörü növésü szobavirág, szokatlanul hozza narancs-sárga virágait. Nyáron szabadban szinten alkalmas. 1 darab $30 \mathrm{c}, 10$ darab $\$ 2.50$.

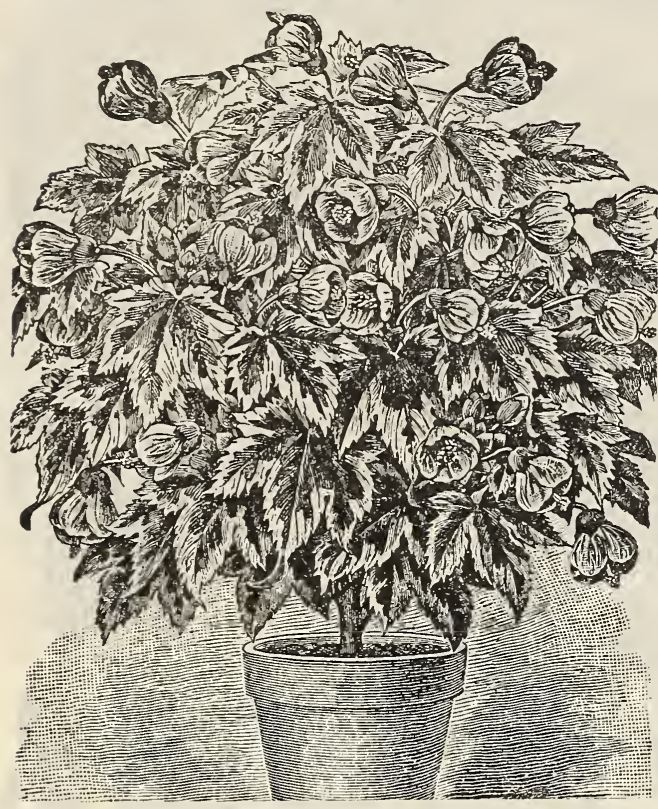

Virágzó Juhar

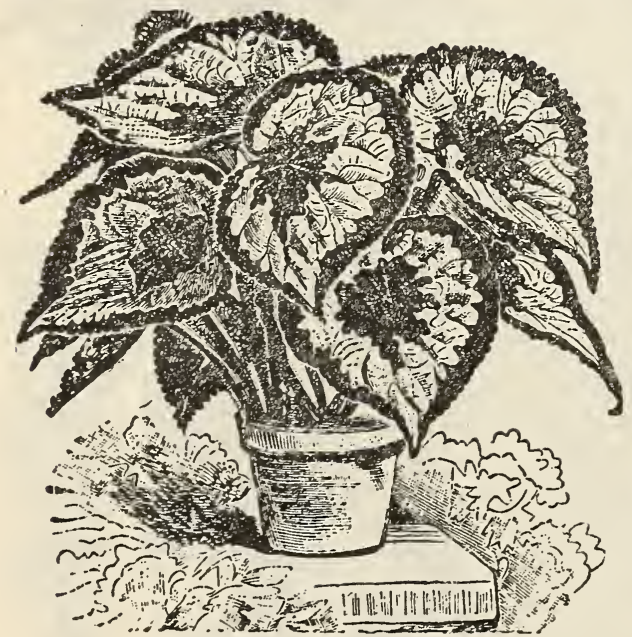

Rex Begonia

BEGONIA REX. Gyönyörü nagy és tarkázott levelú Begonia faj. Remek szobanövényt alkot. 1 darab 35c, 10 darab $\$ 2.50$

\section{Amarillys.}

AMARILLYS HYBRIDA. Hagymás szobanövény remer brilliáns-piros orchidaszerü virágokkal. Az Amaryllisek öntözese októberben abbahagyandó, amikor ugyanis a sumók pihenése következik. Január és februárban a gumók atültetendök friss földbe és az idővel az öntözést is meg

kezdjuk. 1 darab 50 cent, 10 darab $\$ 4.50$.

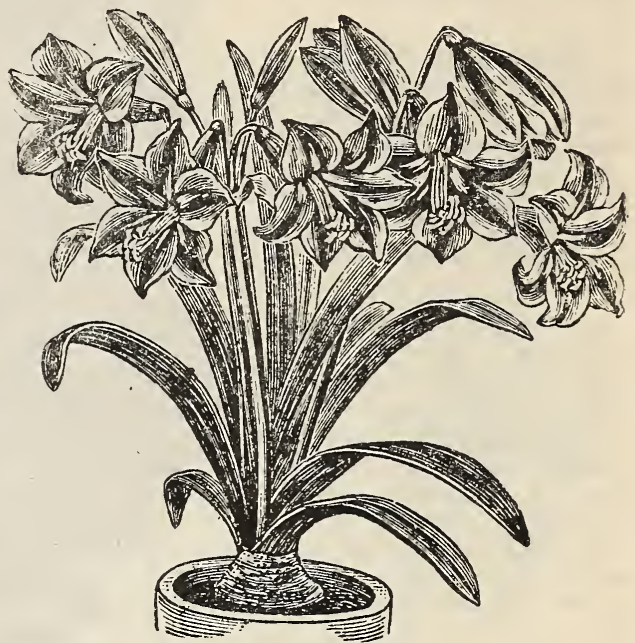

Amarillys.

\section{Folytonnyiló Begonia.}

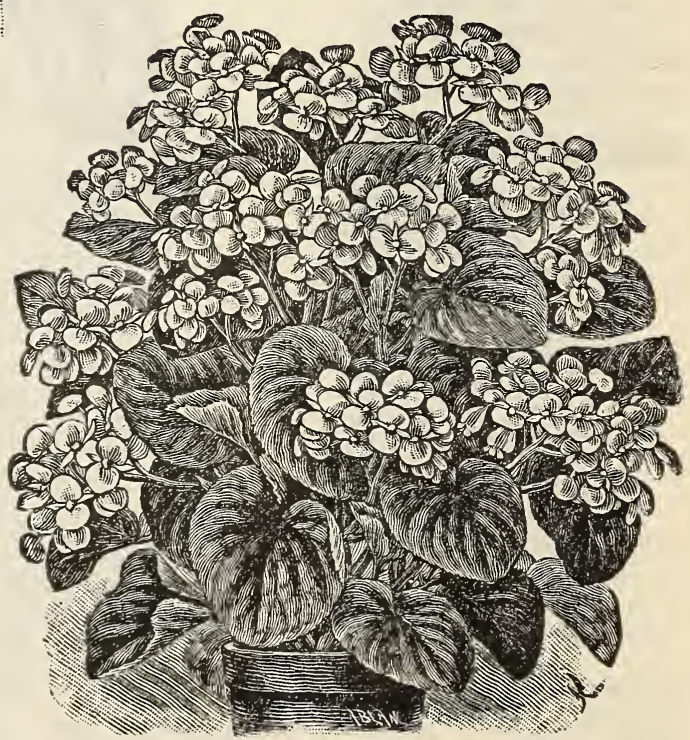

Folytonnyiló Begonia

BEGONIA SEMPERFLORENS. Folyton nyiló apró, lecsungö, rózsaszinü virágu kedvelt disznövény. Nagyon hálás. 1 darab 25c, 10 darab \$2.00. 


\section{Begonia (Pettyezett levelii)}

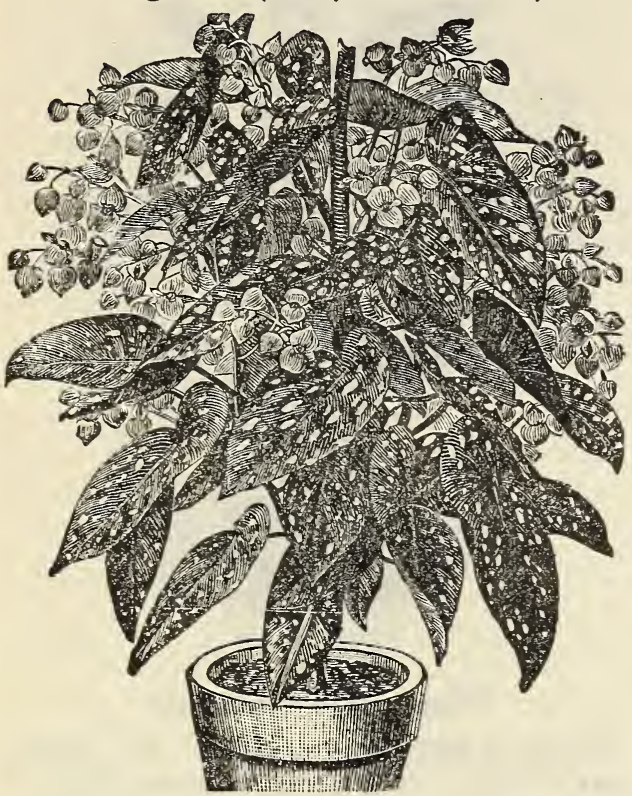

PETTYEZETT LEVELU் BEGONIA. Ezen gyönyörü Begonia minden virágszeretö asszonynak meg kell lenni a szobájában, amennyiben nemcsak virágja, de levele is egész diszt szolgáltat házunkban. Óriási levelei hosszukás alakuak, tele ezüst szinü pettyezetekkel, virágja szine hófehér. 1 darab $30 \mathrm{c} ; 10$ darab $\$ 2.25$.

\section{Calla Eithiopica}

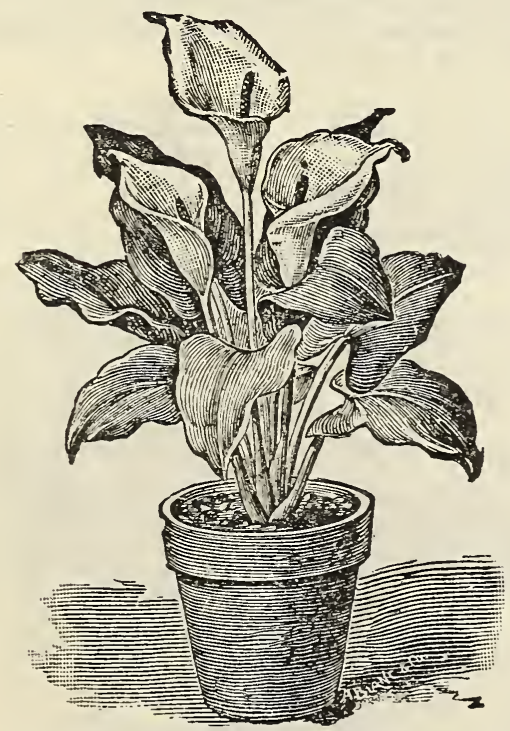

TOLCSÉRVIRÁG HóFEHÉR. Ezen gyönyörü virág egyike a leghálásabbaknak a szobavirágok között. Nem kiván valami különös kezelést és mégis folyton tele van óriás nagy, hófehér, tölcsér alaku virágokkal. Virágja szára $25-30$ inch magas, virágja átméröje $8-12$ inch. Hoszszukás, haragos zöld levelekkel, egész éven át a legszebb szobadisz. 1 darab $50 \mathrm{c} ; 10$ darab $\$ 4.50$.
Spotted Calla - Tölcsérvirág, sárga

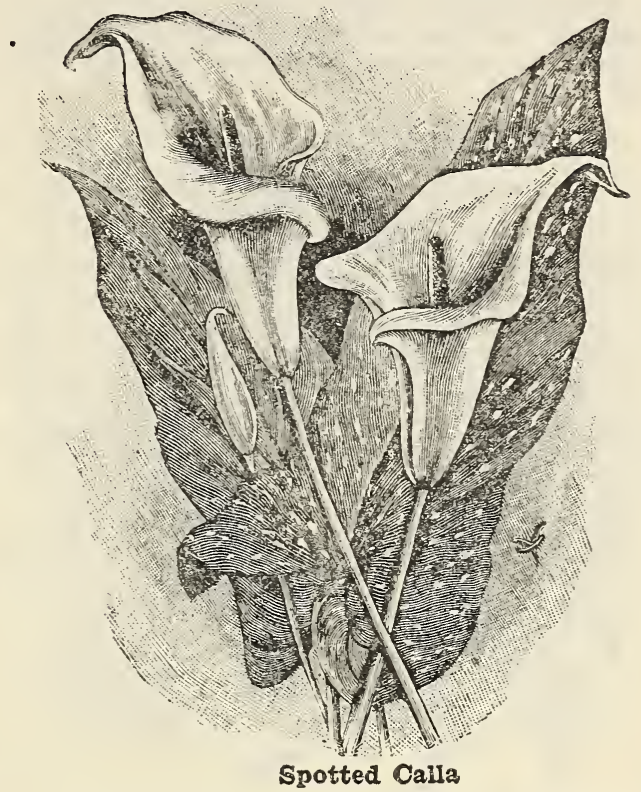

TÖLCSÉRVIRÁG SÁRGA. Virágja alakja éppen olyan, mint a Fehér Tölcsér virágja, csakhogy ennek levele haragos zöld és tele sürüen világos sárga pontokkal, virágja szine pedig sötétsárga. Nyáron nagyon szereti, ha kertekben, szabadban ki van ültetve, virágszára pedig a szabadban néha 3 láb magasra is fölemelkedik. 1 darab 50c; 10 da$\mathrm{rab} \$ 4.50$.

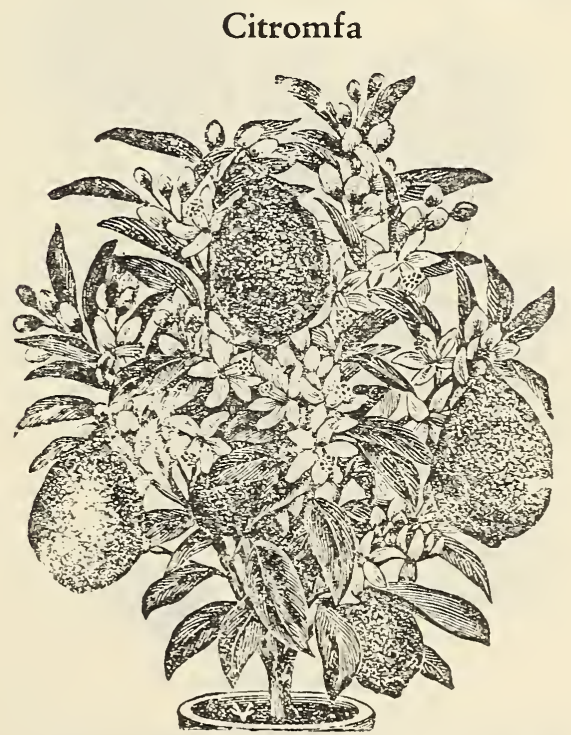

CITROM FÁCSKÁK. Mindenki által régóta kedvelt citromfácskák, gyönyörü szobanövény. Hófehér, illatos virágja van, gyümölcsei pedig óriási nagyra fejlödnek és használhatók. 1 darab 30c; 10 darab $\$ 2.25$. 


\section{Diszspárga}

ASPARAGUS SPRENGERI. Szobákban és ablakok, valamint erkélyek diszitésére, egyike à legszebb növényeknek. Darabonként 25c; 50c. $75 \mathrm{c}$ és $\$ 1.00$.

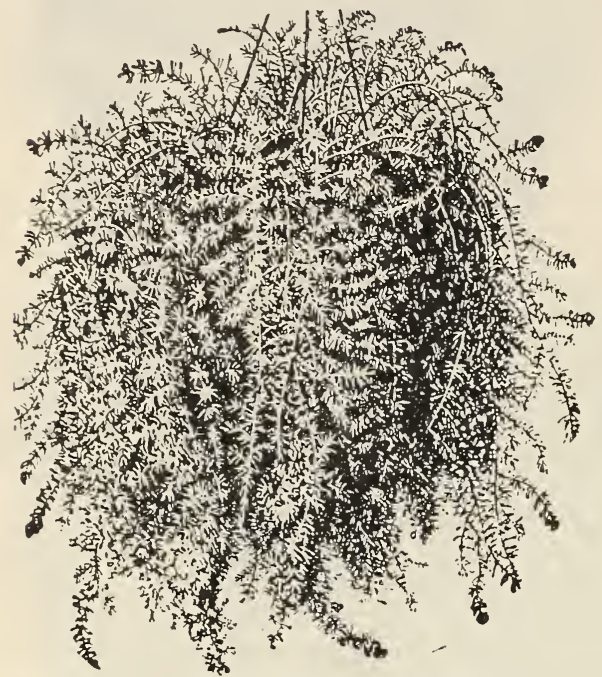

Asparagus Sprengeri.

ASPARAGUS PLUMOSA. Szintén igen szep és tartós szoba disznövény. Hajfinom levélzete és pompás növése folytán igen kedvelt. 1 darab $25 \mathrm{c} ; 10$ darab $\$ 2.50 .2$ éves erös példány 1 darab $\$ 1.00$.

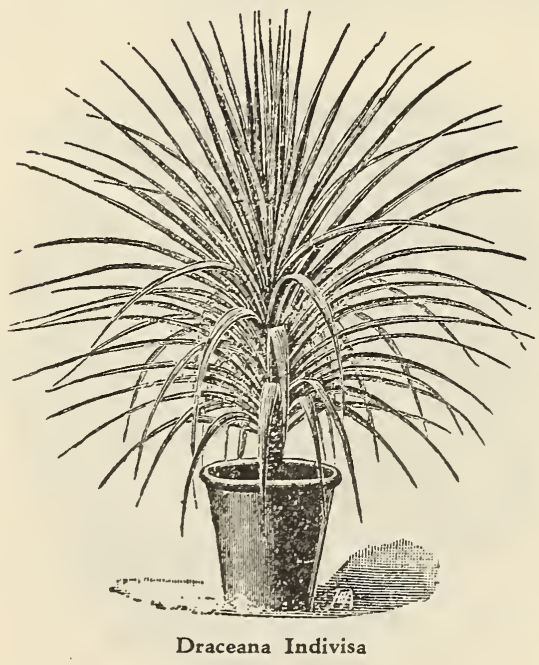

DRACEANA INDIVISA. Igen tartós és hálás szobanövény, hosszu, vékony levelekkel. Remek példányok. 1 darab 25c; 10 darab \$2.00. 2 éves erős példány 1 darab $\$ 1.00$.

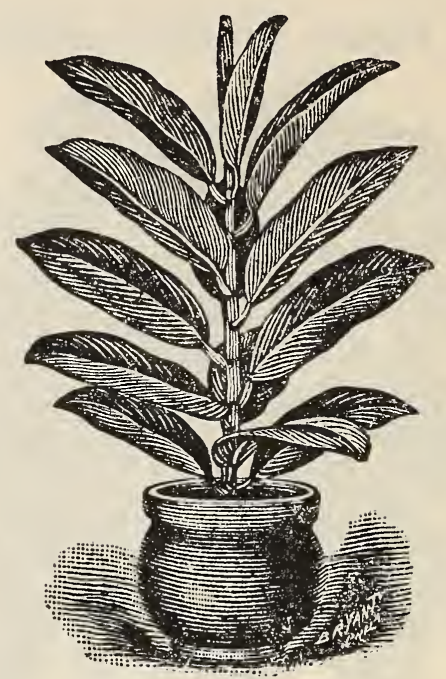

Gummifa.

\section{Fikusz vagy Gummifa}

FICUS ELASTICA. Mindenütt jól tenyész, nagy, sötétzöld leveleivel emeli a szoba diszét. 1 darab $\$ 1.50$.

\section{Fukszia}

FUCHSIA HIBRIDA. Gyors növésü, folyton virágzó, hálás szoba- és ablak virág. Jó kezelés mellett évhosszat folytonosan virit. Teljes és esy. szerü formában, fehér, kék és piros virággal. 1 darab 25c; 10 darab $\$ 2.00$.

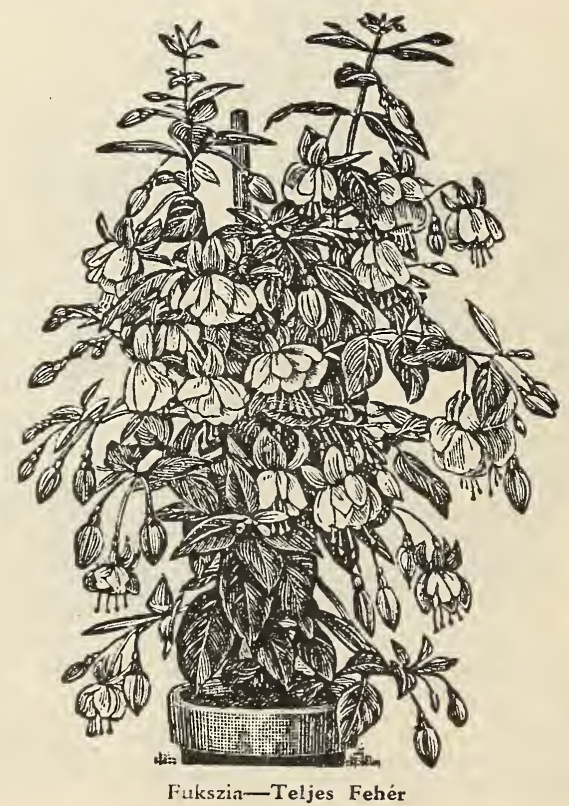




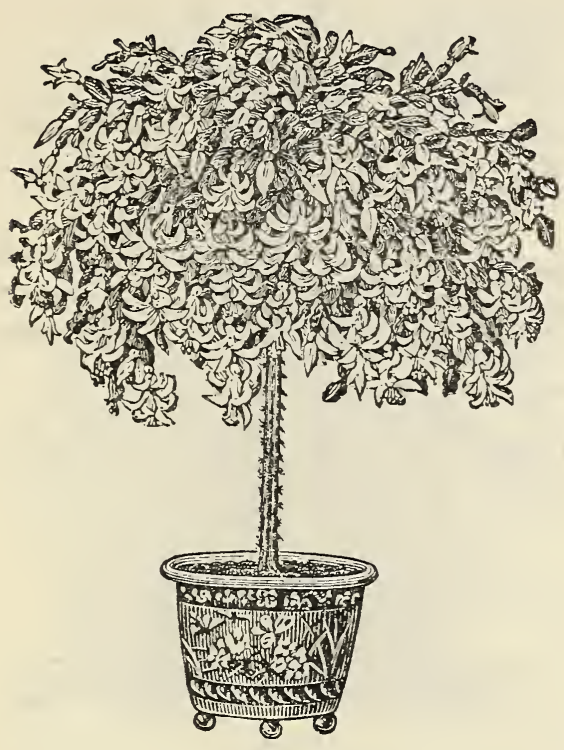

\section{Oltott Kaktusz}

EPHIPHILUM. Oltott kaktusz, egyike a leg szebb szoba-virágoknak. Télen karácsonytájban virágzik, amit soha el nem mulaszt, egy éven sem Virágja szine skarlátvörös, virágjának alakja ha sonlit a Tátika vagy Oroszlánszáj virághoz, csakhogy ez a kaktusz virág jóval nagyobb és mikor virágzásban van, ennél szebbet el sem lehet kep. zelni. Egy éves oltás, 4 colos cserépben (vayy' tégelyben) 1 darab $\$ 1.50$.

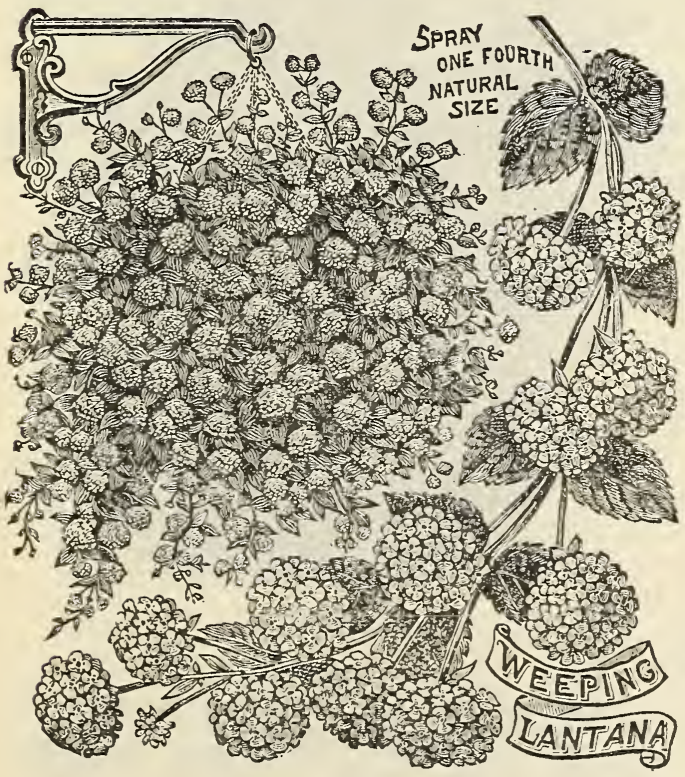

Lantana Mézvirág

\section{Lantana Mézvirág}

LANTANA - MÉZVIRÁG. Leghálásabb és legszebb szobavirág, akár porcsokra való beszketekben, akár cserepekben dusan tenyészik. Ahogy nö, minden ágán minden levél mögött egy labdához hasonló viágot hoz, a legremekebb szinváltozatban. Skarlát, bordóvörös, sárga, fehér és rózsaszin. Bármely szin. 1 darab 25c; 10 darab \$2.00.

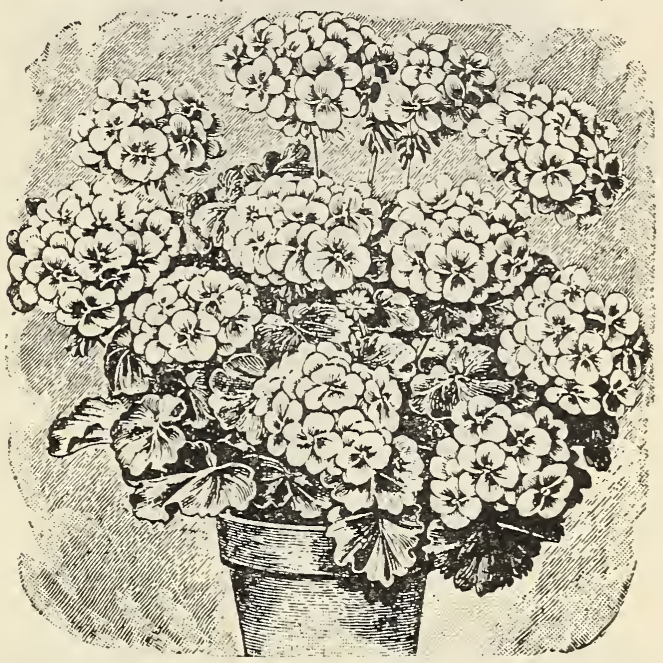

Muskátli vagy Mályva

\section{Muskátli}

MUSKÁTLI VAGY MÁLYVA.-Pelargonium Zonela. Teljes és egyszerü virágu diszfajok, fehér, vörös vagy rózsa szinekben. Bármely szinben. 1 darab 20c; 10 darab $\$ 1.75$.

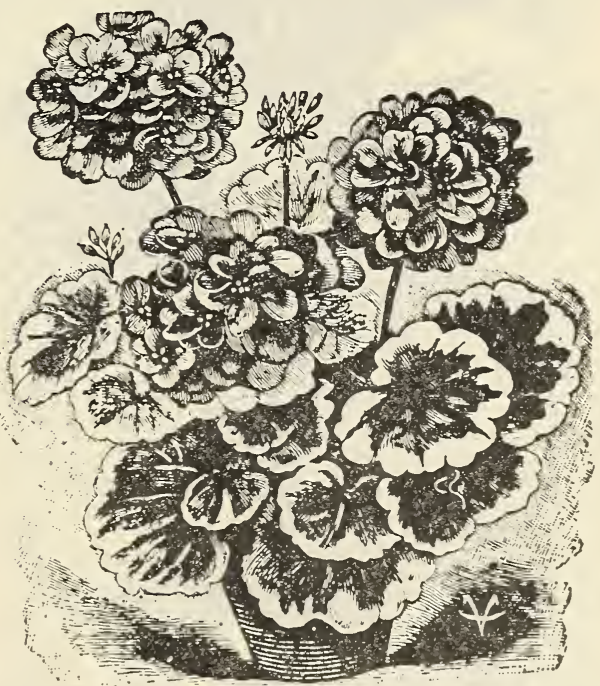

Muskátli Tarka

\section{Tarka Muskátli}

MUSKÁTLI TARKA. Tarka levelü muskátli. Leve lének külseje, félig fehér, belseje zöld, virágja pedig skar látvörös. Legpompásabb szoba növény. 1 darab 25c; 10 darab \$2.00. 


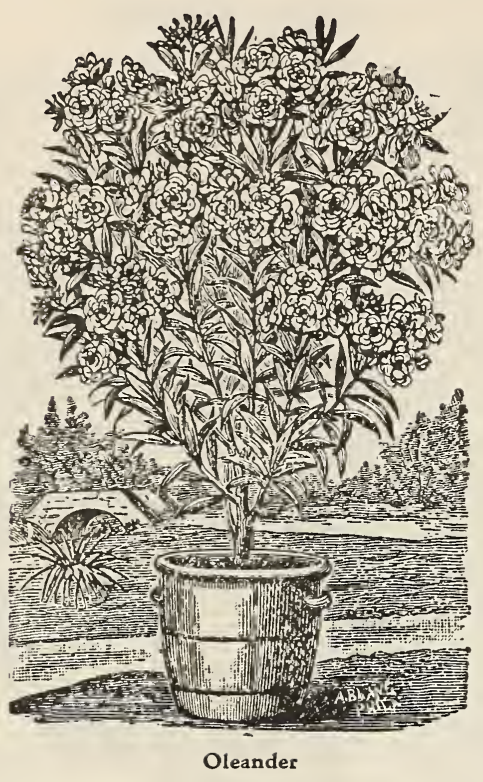

Oleander

NERUM OLEANDER. Pompás fácskák remek piros, fehér, sárga és rózsaszinekben. 1 darab 25c; 10 darab $\$ 2.00$. 2 éves palánta darabja $75 \mathrm{c} ; 10$ darab $\$ 6.00$.

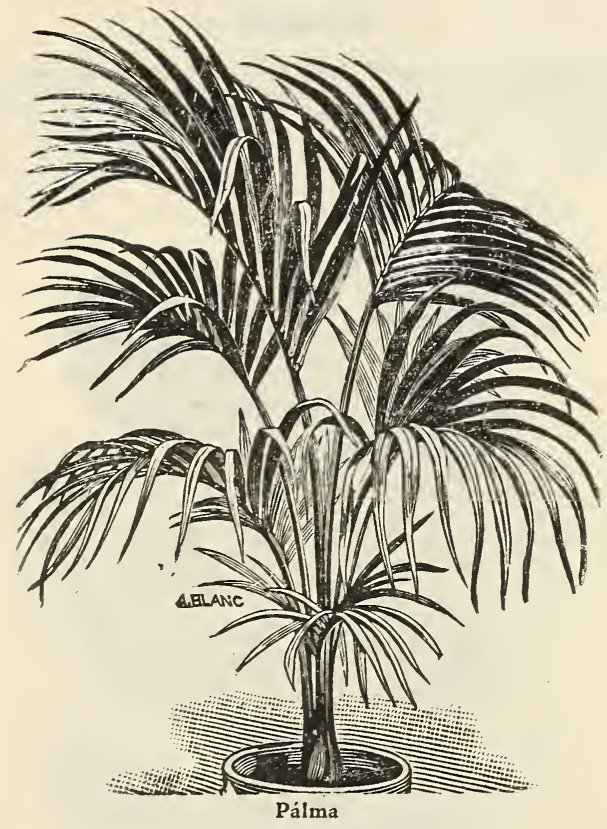

Pálmák

KENTIA BALMOREANA. Gyorsnövésü, elsőrendü diszpálma. Nagyon egyszerü gondozás mellett gyönyörú példányokká fejlödnek. $10-12 \mathrm{col}$ magas. Egy darab $30 \mathrm{c} ; 10$ darab $\$ 2.50 ; 2$ láb magas 1 darab $\$ 3.50 ; 3-4$ láb magas 1 darab $\$ 10.00$.

LATANIA BORBENICA. Valódi legyező pálma, fejedelmi alakkal. Levelei néha $1-2$ láb szélesre is megnőnek és állása akár egy legyezö, $10-12$ col magas. 1 da. rab 30c. 10 darab \$2.50; 2 láb magas 1 darab \$4.00.

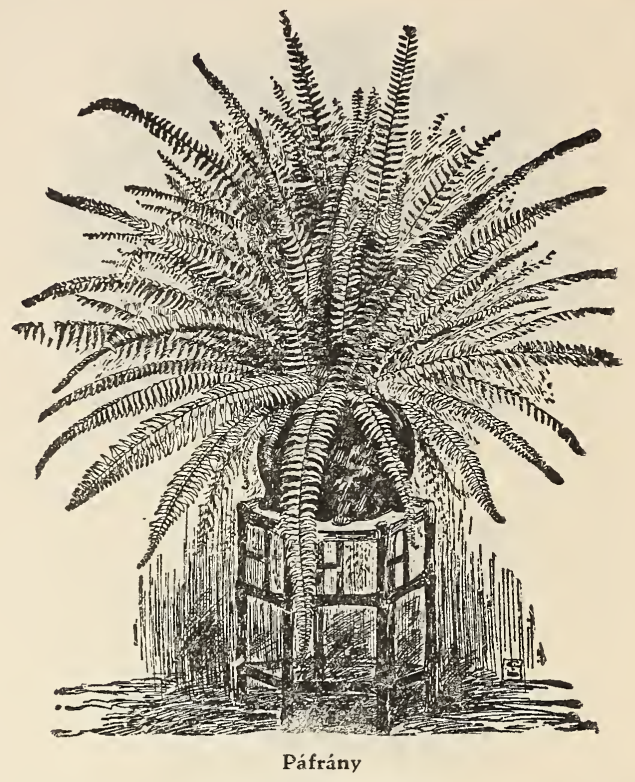

\section{Páfrány}

NEPHROLEPIS BOSTONIENSIS. Szobákban asztalok és ablakok diszitésére a legalkalma. sabb. Szép hosszu levelekkel. Jó gondozás mel lett néha levelei $5-6$ láb hosszura nyulnak. Na pot nem kiván és lehet a szobának bármely vilá gosabb részén tartani. 8-12 col magas. 1 darả $20 \mathrm{c} ; 10$ darab \$1.75. 2 éves erös példányok $1 \mathrm{da}$. rab $\$ 1.00$.

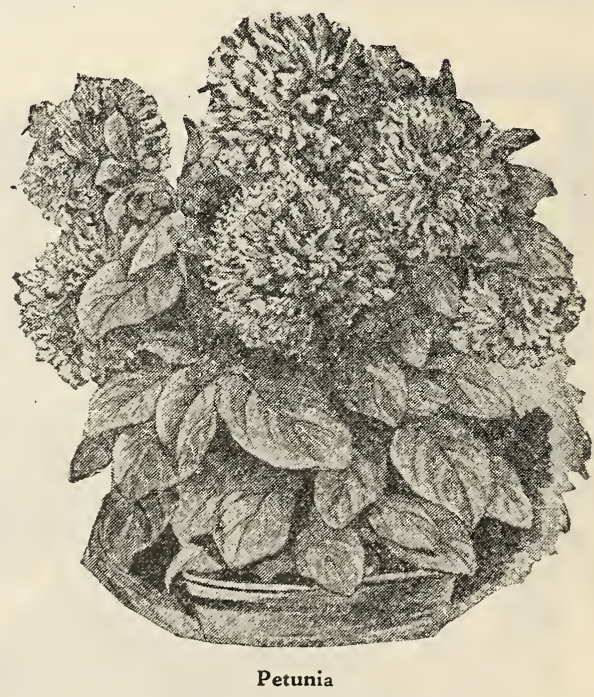

\section{Petunia}

PETUNIA HYBRIDA. Teljes vírágu petuniák. Cso. dás szépségü szinfajokban. Virágjaik nagysága néha 3-4 col átmérőjü. Pünkösdi rózsához hasonlit. Piros, rózsaszin, kék és fehér szinekben. 1 darab 25c: 10 darab $\$ 2.00$. 


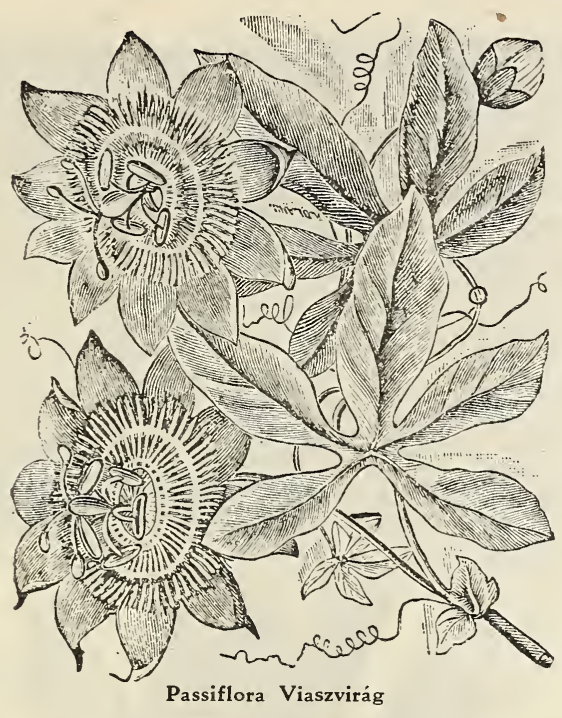

Passiflora Viaszvirág

VIASZVIRÁG. Nagyon hálás futó szoba virág. Gyönyörü fényes levelei és remek virágja nagyon értékessé te szi ablakainkat. 1 darab $25 \mathrm{c}$; 10 darab \$2.00.

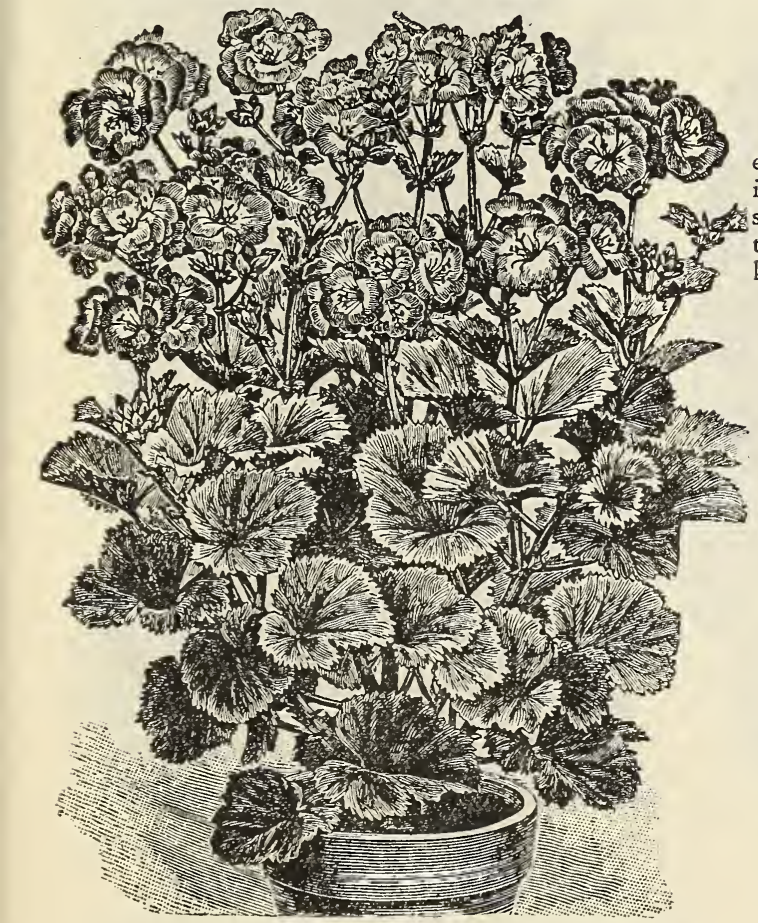

Angol Pelargónia

\section{Angol Pelargónia}

ANGOL PELARGONIA. Finom szobavirág piros, fe. hér, rózsaszinü és gesztenye-barna tarka virágokkal. A lésezó legszebb pelargonia faj. Kellö gondozás mellett igen gyorsan fejlödik. 1 darab 30c; 10 darab $\$ 2.50$.

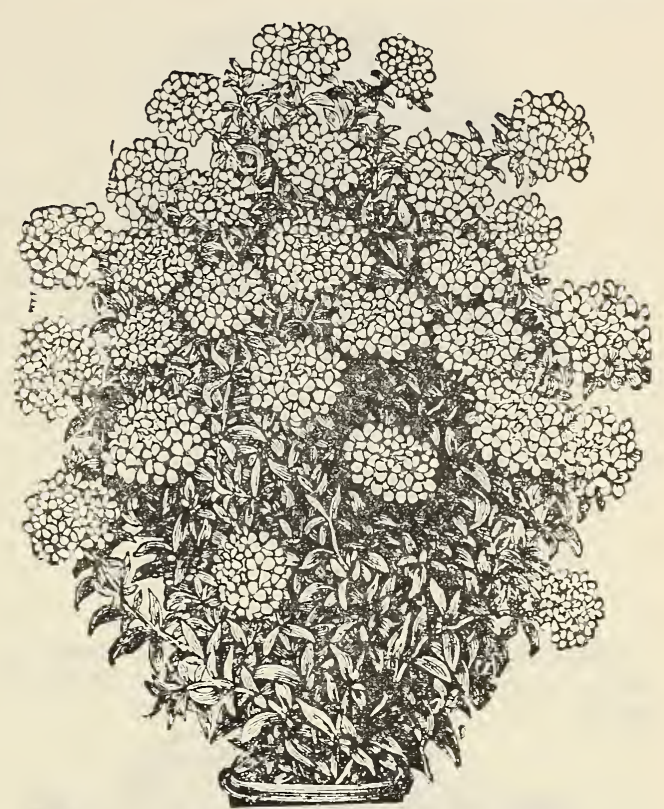

Plumbago Kék Lapda

\section{Plumbago Kék Lapda}

KÉK LABDA. A magyar honfitársak elotr ezen hálás virág még nagyon ismeretlen, de annál inkább ismeri az amerikai nép, mert gyönyörü szoba- és nyáron szabadbani virág. Virágzáskor tele van gyönyörü, labdaalaku, ibolyakék virágok kal. 1 darab $25 \mathrm{c} ; 10$ darab $\$ 2.00$.

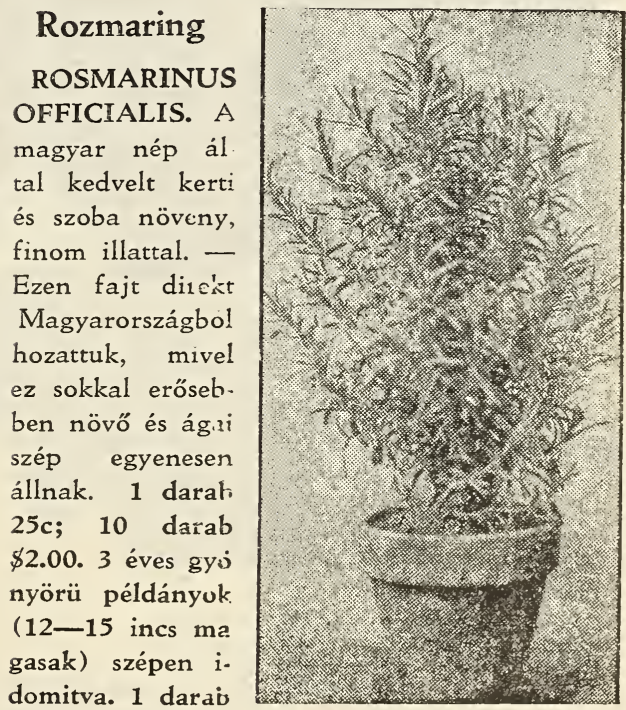

$\$ 1.00 ; 10$ darab

$\$ 7.50$.

Rozmaring 


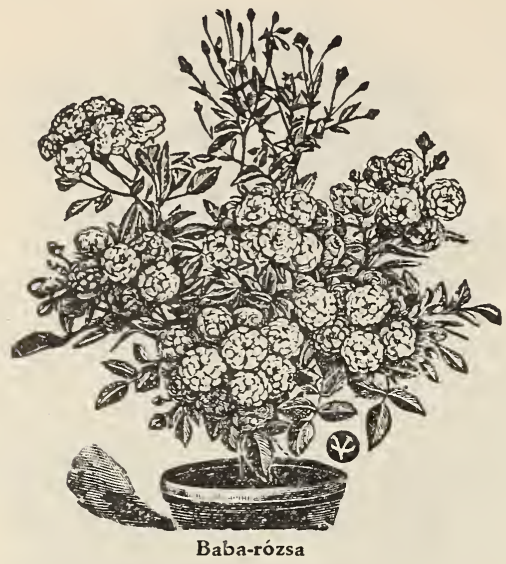

JAPÁNI JEG-
VIRÁG. Csolá-
latos tartós szo-
ba növény. Ne-
velése egyszerü,
mert sok vizet
nem kiván, me-
leget is csak any-
nyit, hogy meg.
ne fagyjon. Le-
velei majdncm
gömbölyüek, hu-
sosak, akár a kak
tuszé. Virágja ró-
zsaszinü és virág
zási ideje janu-
ár hónap. 1 da-
rab $25 c ; 10$ da-
rab \$2.00.

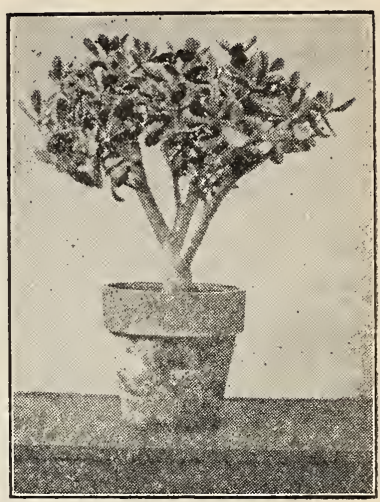

Baba-rózsa

BABY RAMBLER. Folyton virágzó cseresznyepiros, hónapos rózsa. -.1 darab 75c; 10 darab $\$ 6.50$.
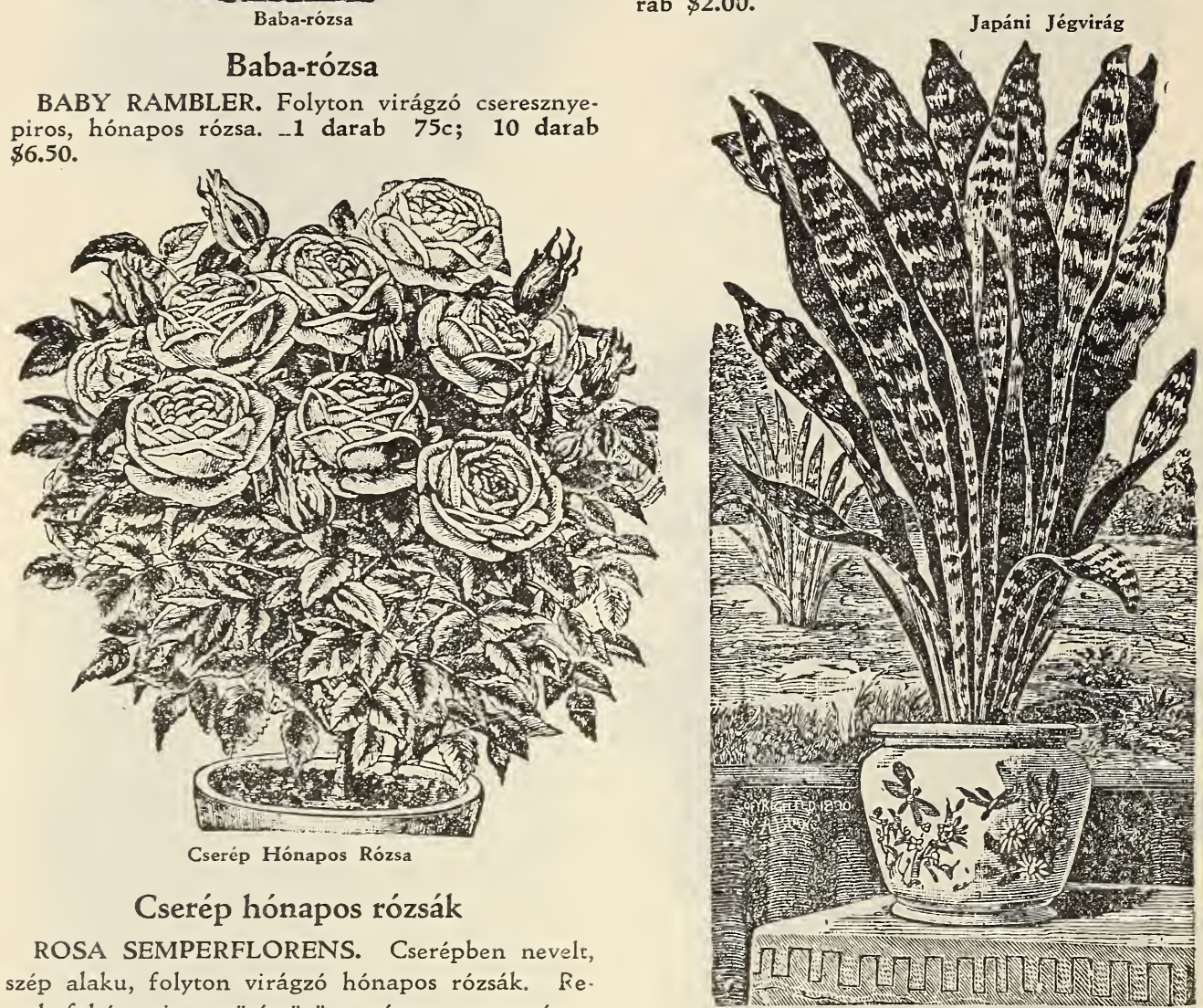

ROSA SEMPERFLORENS. Cserépben nevelt, szép alaku, folyton virágzó hónapos rózsák. Re mek fehér, piros, sötétvörös, sárga vagy rózsàszinben.

GRUS ON TEPLITZ. Bordópiros.

HERMOSA. Rózsaszin.

CLOTILDE SOUPPERT. Fehér.

PERLES DE JARDINS. Sárga.

Darabja bármely szinben $70 c ; 10$ darab $\$ 6.00$.

MARSHAL NIEL. Aranysárga, 1 darab $75 \mathrm{c}$ : 10 darab $\$ 7.00$.

\section{Sansevieria - Zebra Virág}

SANSEVIERIA - ZEBRA VIRÁG. Elnevez: sét azért kapta a zebráról, mert hosszu, husos kar : levelei keresztben tele vannak sárga csikokkal, eppen ugy, mint a zebra. Egyike a leghálásabb szoba-növényeknek, birja a nedvességet, szárazságot, gőzt egyaránt. Levelei néha 3 láb magasra is fel. nyulnak. 1 darab $25 \mathrm{c} ; 10$ darab $\$ 2.00$. 


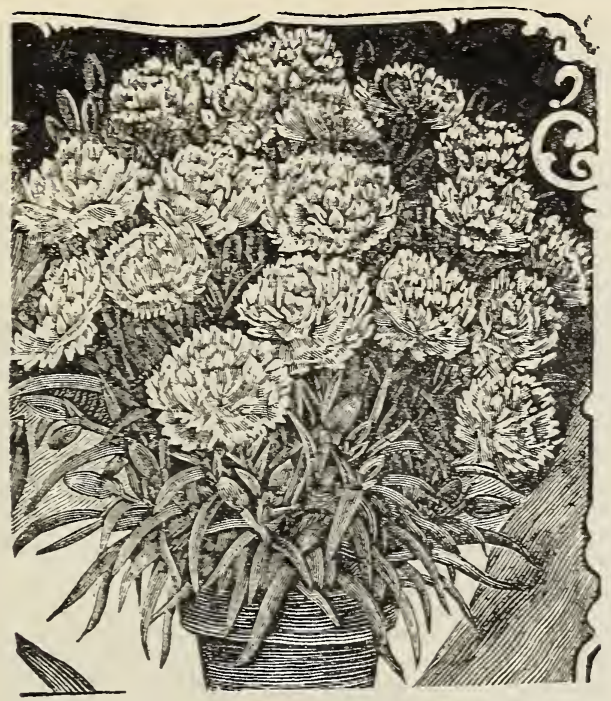

Cserép Szegfü

\section{Cserép Szegfü}

DIANTHUS CAROPHYLIS FL. PL. A rózsán kivül a legelökelöbb helyet foglalja el a szekfü. Pompás fehér és rózsaszinekben.

HARLOWARDEN. Bársonyos sōtétvörös. ROSE ENCHANTRES. Sötét rózsaszinü.

WHITE ENCHANTRES. Tiszta fehér.

KANÁRI SARGA.

Bármely szinböl 1 darab 25c; 10 darab $\$ 2.00$.

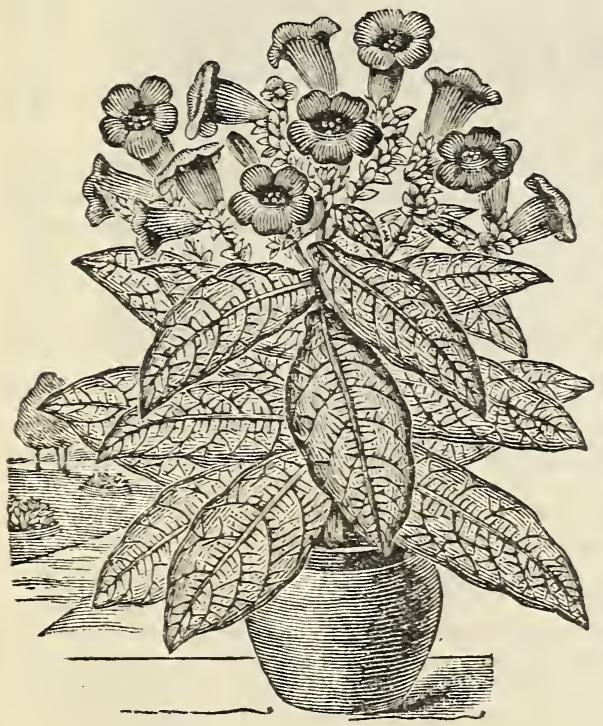

Strobilantus - Mágnás Kékvirág

STROBILANTUS - MÄGNÄS KÉKVIRÁG. Legnemesebb növény ugy virágja, mint gyönyörü szines levelénél fogva. Levelei 8-10 col hosszuak, gyönyörü égszinkék és rózsaszin csikokkal. Virágja szine ibolyakék, trombita alakuak. A legremekebb nyáron virágágyakban, ugyszintén cserepekben szobában. 1 darab 25c; 10 darab \$2.00.

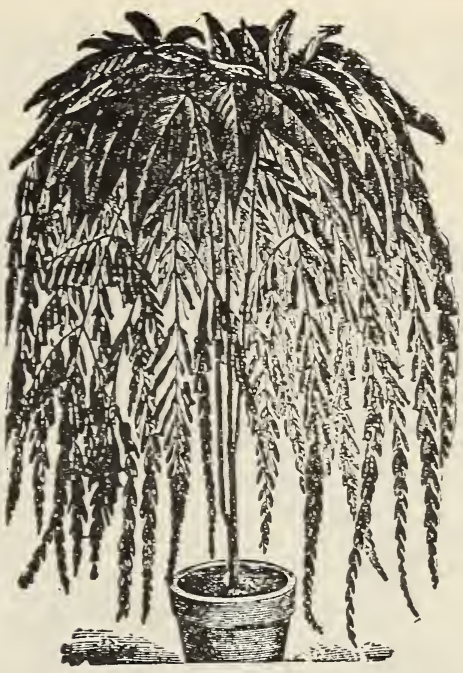

Sugár Virág

\section{Sugár Virág}

SUGAR VIRẢG. Gyors növő és tartós szobavirág. Majdnem egész éven át folyton virágzik. Virágja sugár alakban esüng lefelé és hónapokig eltart. Virágja szine gyönyörü skarlátvörös, levelei szintén szép sötétbarna szinüek. Egyike a leghálásabb szoba virágoknak. 1 darab $25 c ; 10$ darab $\$ 2.00$.

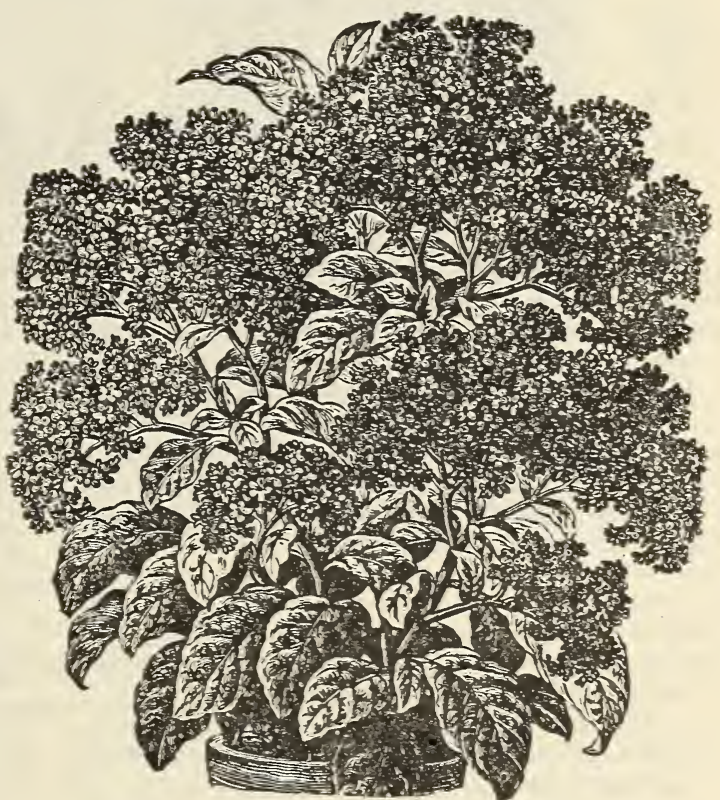

Vanilla

Vanilla

HELIO TROPPIUM. Igen kedvelt virágágyi növény lilaszinü és kitünö illatu virágokkal. 1 darab 25c; 10 da. $\mathrm{rab} \$ 1.75$. 


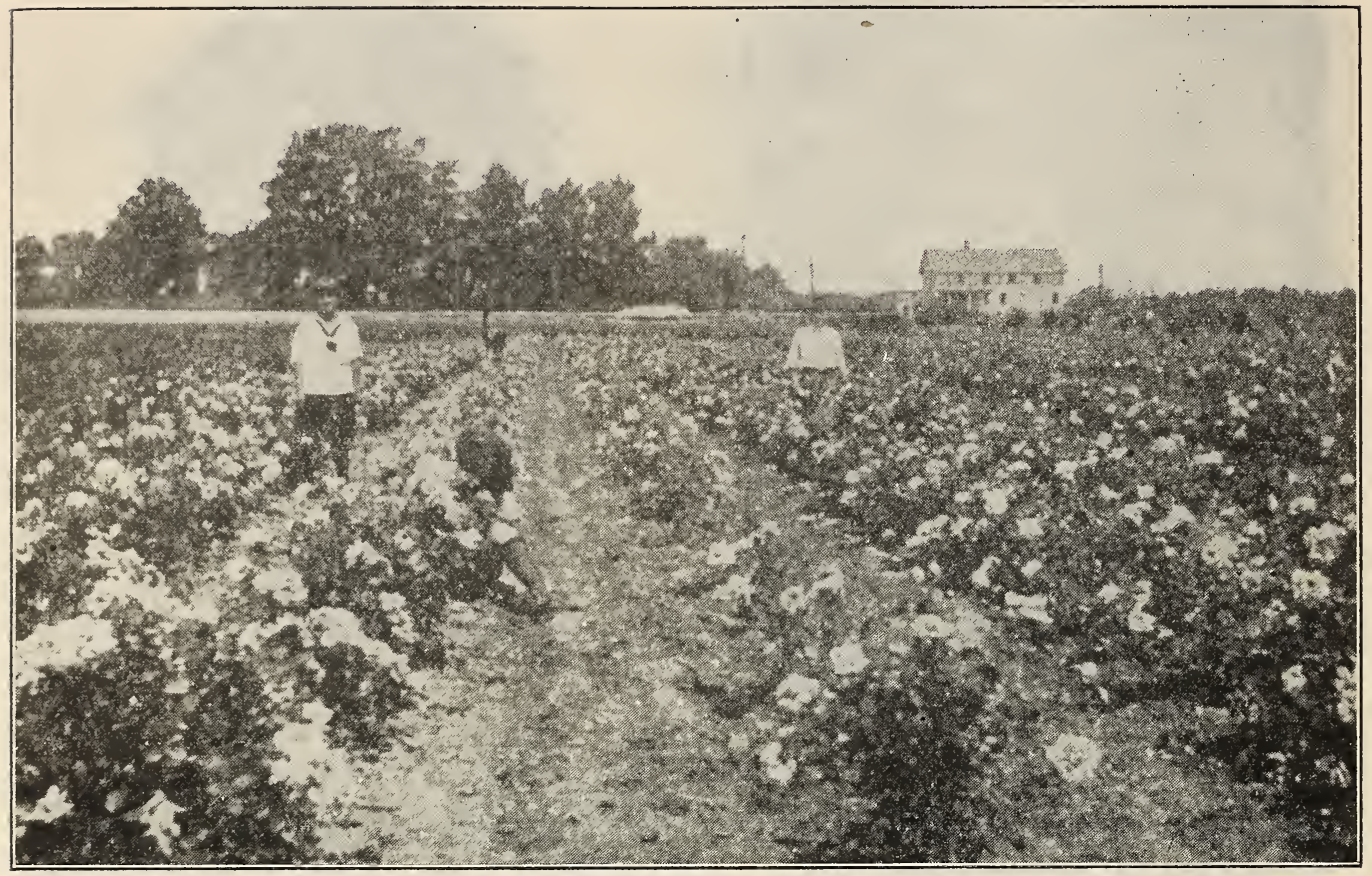

Telepeink egy része. Több hold terjedelmü tearózsák virágzásban.

\section{EGY ÉS MÁS A ROZSAFÁKRÓL}

$\mathrm{Az}$ ültetés ideje. A bokorrózsák és a futórózsák legalkalmasabb ültetési ideje az ősz, vagy a tavaszi március és április hónapok, amikor a ro. zsák a leggyorsabban gyökereznek és ugyanabban az évben gazdagon viritanak.

Kezelés a megérkezéskor. Ha a rózsák gyoke rei megérkezésükkor szárazságot mutatnának, te gyük a gyökeret vizzel telt edénybe egy napig, ha pedig a rózsák szárai is fonnyadtak voinának, ássuk be őket a földbe és takarjuk be az egész rózsatőkét, ugy, hogy teljesen takarva legyenek azok nedves földdel s csak két-három nap mulva vegyuk ki onnan öket, amikor már teljesen felfrissültek és ültessük őket állandó helyükre. A kipakkolásnài arra is nagyon vigyázzunk, hogy az a nap melego és szelek által védett helyen történjék.

A rózsaágy fekvése. Ha csak lehet, napos és zord északi szelektôl védett helyet válasszunk $k i$ rózsaágyak részére.

A talaj és annak elkészitése. A rózsafajok leyjobban diszlenek tápdus, agyagos talajban, de mindazonáltal kitünóen diszlenek bármely kertı földben is. Mieiött a rózsák ültetéséhez fognánk. forgassuk meg a talajt (ássuk fel) 1-2 láb mélységre és ha nem lévén elég tápdus, az jól érett tehén-, vagy ló-trágyával összevegyitendő.
Az ültetés. Ássuk a gödröket oly tágasra, hogy elég nagyok legyenek a gyökerek kényelmes befogadásàra. Ültessük a rózsákat oly mélyre, mint a faiskolánkban voltak ültetve. Továbbá az ültetésnél ügyeljünk arra is, hogy a föld felső resze (humus) jusson közvetlen a gyökerekhez és a föld szilárdan oda legyen tapadva a gyökerekhez.

A metszés. A rózsafákat általànosan az egèsz rajta növött ágakkal küldjük szét, amiket hibás volna ugy elültetni, ahogy megkapjuk, hanem az ujonnan ültetett rózsákat, ha azok tavaszon van nak ültetve, 3-4 ágra hagyjuk csak meg, a több: ágakat pedig éles késsel, vagy kerti ollóval levágjuk; a meghagyott ágak pedig 3-4 szemre vissia. vágandók. $\mathrm{Az}$ őszön ültetett rózsák ágai megha. gyandók és csak tavasszal kell azokat is visszavác: ni az elöbbeni mód szerint. Az ily módon metszett rózsák biztos eredményt és bö virágzást huz. nak. Ültetés után a rózsák jól beöntözendők.

A további gondozás. El ne mulasszuk a gyökérről és a törzsről jövő vad hajtásokat éles késsel simára levágni és viritás után az elvirágzott rózsavirágokat mindig leszedjük, ugyszintén a rovarokat is gondosan le kell szedni, ha azok mutatkoznának a rózsaleveleken. 

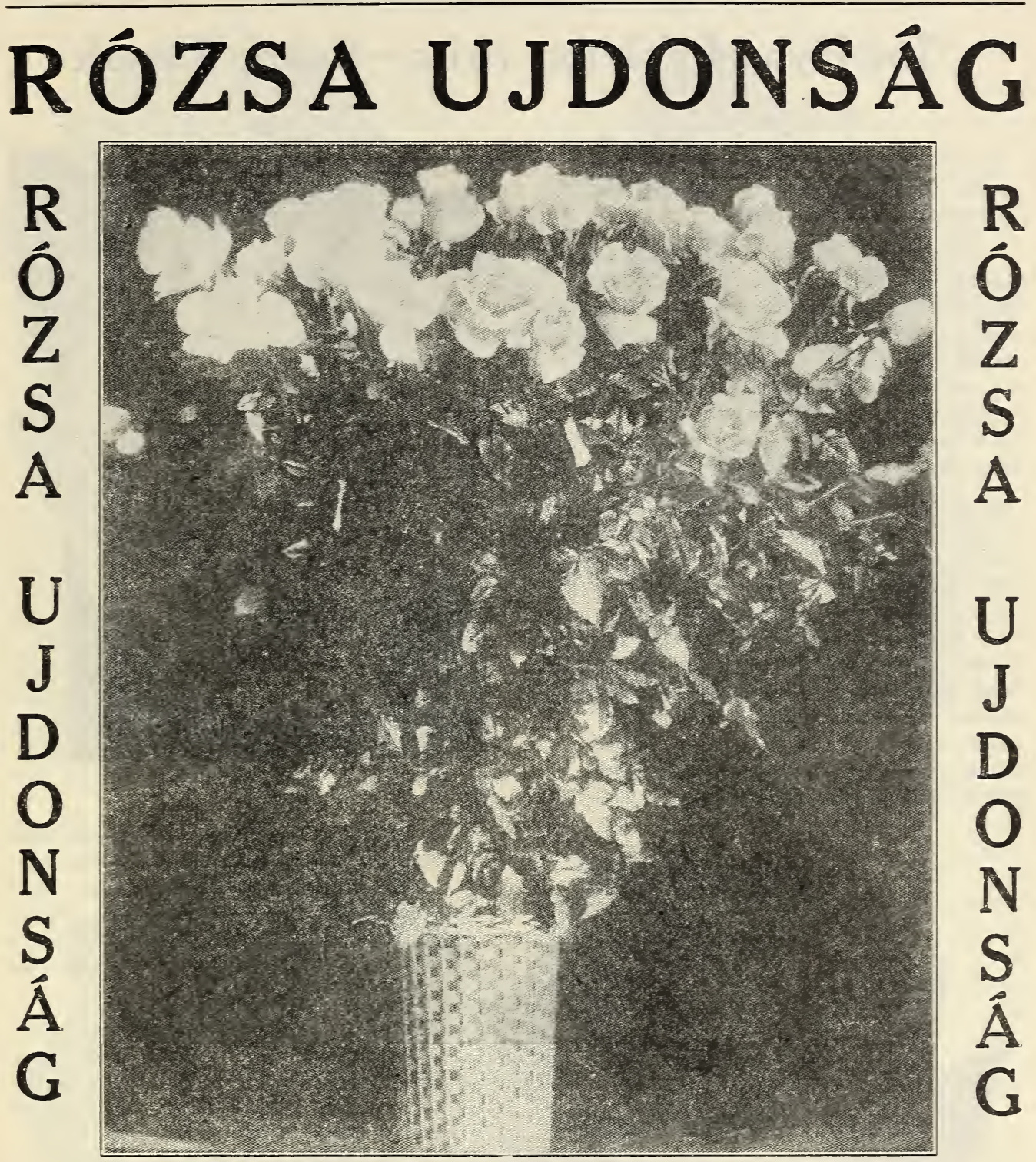

Pernet

Souvenir de Claudius Pernet. Az ugynevezett rózsák aranykirálya. Ezen gyönyörü rózsa ujdonság remek szinénél, bö virágzásánál és erős növésénél fogva, a legelső helyet foglalja el az összes rózsák között. Virágja szine sötét sárga, alakja bimbó korában, hosszas, kinyiltan pedig a legteljesebb. Levelei haragos fénylö zöld, szára pedig majdnem teljesen tüske nélküli. Mint vágott rózsa a legelső helyet foglalja el. Az amerikai rózsakedvelő közönség, a nagyon ismert American Beauty rózsához hasonlitják, mint vágott rózsát.

Az egész Amerikában szebb példányok nem találhatók, mint amelyek a mi telepeinken láthatók. Ára 1 darab 1.50, 10 darab \$12.50. 


\section{Tea-Hybrid Folyton virito-Bokor Rózsák}

\section{RÓZSÁK}

SZIVES FIGYELMÉBE! Az alább felsorolt, eladásra ajánlott rózsáink két osz. tályra oszlanak, még pedig:

TEA-HYBRID RÓZSÁK. A rózsafaj ma kétségkivïl a létező legszebb virág. Fajának szép növése, gyönyörü alaku virágainak teához hasonló illata és egyéb kiváló tulajdonsága folytán a rózsabarátok kedience, mert kora tavasztól egész hideg čszig folyton viritanak. A tea-hybrid rózsák sok. kal kényesebbek, mint a Remontant-fajok és korai, jó téli takarást igényelnek.

REMONTANT TÉLÁLLÓ VAGY TÖBB. SZÖR VIRÁGZÓ RÓZSÁK. Ezen rózsata ma az elsö helyet foglalja el, nagy elien. álló képessége folytán, kivált zordonabb fek. vésü helyekre alkalmazva. A Remontant, vagy a többször virágzó rózsák a legsötétebb bordó piros és a legillatosabb fajokat fog. lalják magukban és virágzáskor gyönyorti látványt nyujtanak. Földdel teljesen elegendő takarni - vagy még ennyi takarót sem kiván - mert enyhe télben még a kintmaradt hajtások sem fagynak meg.

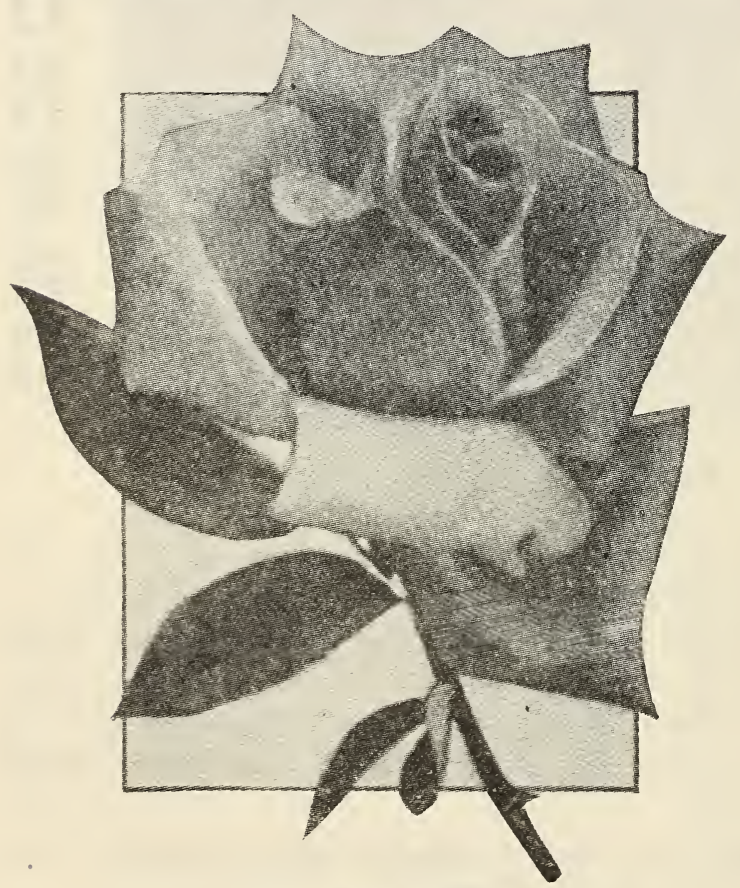

Double White Killarney

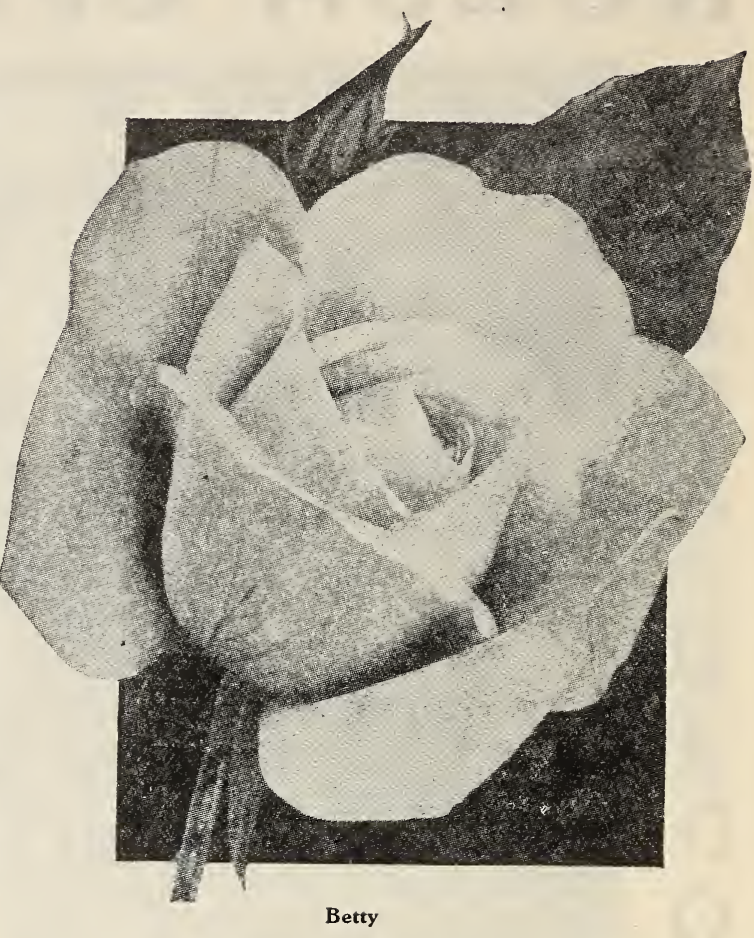

BETTY (Tea-Hybrid.) A legszebb feher tearózsa, amely eddig tenyésztve van, miert is minden kertben található. Fája elegan san elágazó, levelei mély zöldek, virága: ideális alakuak, gyengén tejszin fehérek és a legkellemesebb illatuak. 1 darab 90c; 10 darab $\$ 8.50$.

BUTTERFLY (Tea-Hybrid.) Folyton virágzó tearózsa faj, remek, kecses, hossz: alakiu bimbókkal. Virágja szine narancssárga és kitünő illatu. 1 darab 90c; 10 da$\mathrm{rab} \$ 8.50$.

COLUMBIA (Tea-Hybrid.) Nagyon kedvelt, pompás rózsafaj. Növése erős. Virágja igen nagy, gyengén ezüstös rózsaszi. nüek. Rendkivül dusan virágzó és finoı! illatu virágokkal. 1 darab $90 \mathrm{c} ; 10$ darab $\$ 8.50$.

DOUBLE WHITE KILLARNEY. Az összes rózsatenyésztők megegyeztek abbar, hogy ezen rózsa az összes rózsák között a legtisztább fehér, ami csak létezik és a leg. több virágot hozza évente az összes rózsár között, juniustól egész hideg őszig virıt, bimbó korában gyönyörü alaku, illata pedig felülmulhatatlan és a házi kertekből nelkü. lözhetetlen. 1 darab 90c; 10 darab \$8.50. 


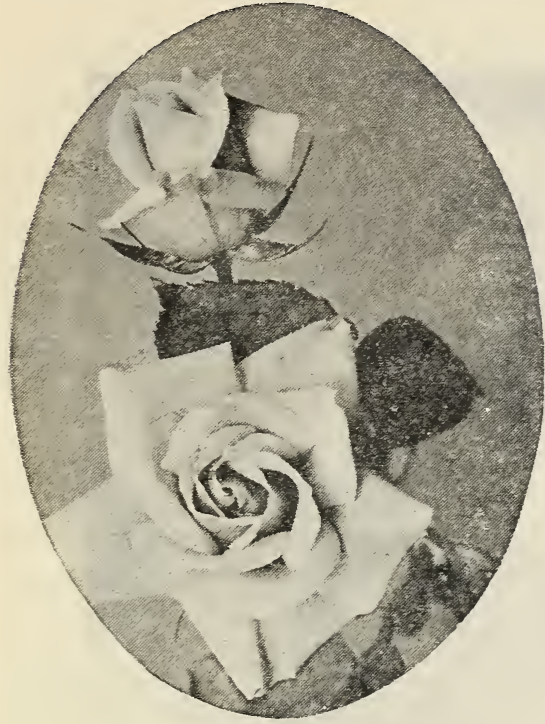

Gen. McArthur

GENERAL McARTHUR. A legajáníatosabb tearózsa házi kertek és rózsaảgyak részére. Bimbója kecses, megnyult, a virágjának szine pedig remek skarlát fẻnyió vörös. Nagyon hálásan virágzik. 1 darab 90 c; 10 darab $\$ 8.50$.

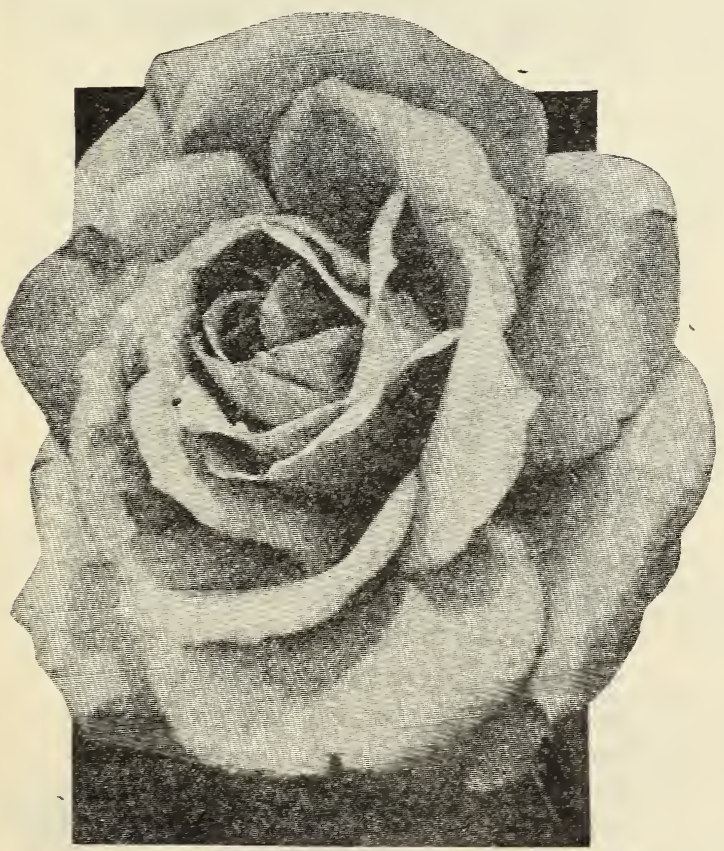

Gruss on Teplitz

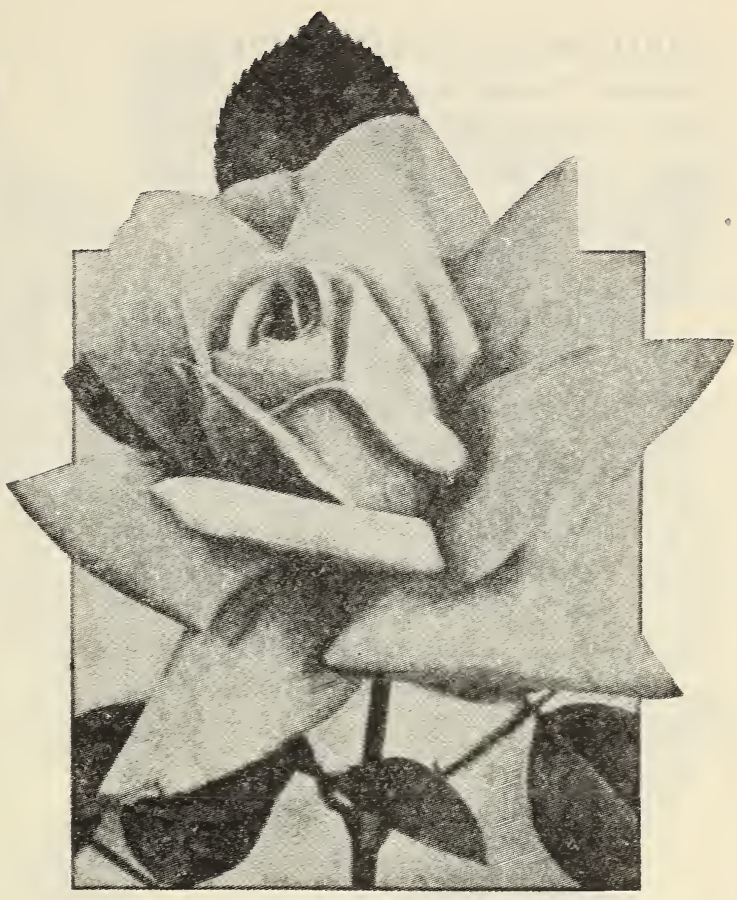

Los Angeles

LOS ANGELES. Ezen gyönyörü rózsaujdonság Amerika leggyönyörübb állama. ban, Californiában let feltalálva és Califr.t. nia legszebb városa nevéröl lett elnevezv... Los Angeles. Növése a legerősebb az ösz. szes tearózsák között, a virágszárak neira három lábra is fölemelkednek, virágnagysả ga bámulatos nagy, - majdnem ak'zora, mint a nagyon ismert Paul Neyson rózsák. Virágja szine, szirmok külső széle tüzes ic่. zsaszin, beljebb a szirmok bronz szinü.ək. legközépen arany-sárga. 1 darab $\$ 1.00 ; 10$ darab $\$ 9.00$.

JANKHEER J. L. MOCK. Ezen rózsaujdonság az egyedüli, melyre az ezüstszint rá lehet fogni. A virảg-szirmok kịlso" széle gyenge rózsaszin, a virág belseje pelig valódi ezüst szin. Ezen gyönyörü rózsa több kiállitáson 2 arany érmet, 1 ezüst ér. met és 5 első dijat nyert el. Növése leg. erősebb az összes tearózsák között. 1 darab 90 c; 10 darab $\$ 8.50$.

\section{GRUSS ON TEPLITZ (Tea-Hybrid.)} Remek fénylö, bársony-piros szinü és illatos virágokkal. Ällandóan virágzik. 1 darab $90 c ; 10$ darab $\$ 8.50$. 


\section{MADAME EDWARD MAWLEY.} Gyönyörü bársonypiros tea rózsa. Virágjai óriási nagyok és teljesek, növése dus és kora tavasztól hideg öszig virágzik. Természetes szine az árjegyzék tábláján látható. 1 darab $90 \mathrm{c} ; 10$ darab $\$ 8.50$.

OPHILIA. Legujabb és leggyönyörübb sárga rózsák egyike, amerikai találmány, egy bostoni rózsakertész. mutatta be a bostoni rózsakiállitáson 1914-ben és az első arany érmet nyerte el vele. Szine bimbó korában gyönyörü bronzvörös és sárga árnyalattal, kinyilt korában a legtisztább brilliant narancs-sárga. 1 darab 90c; 10 darab $\$ 8.50$.

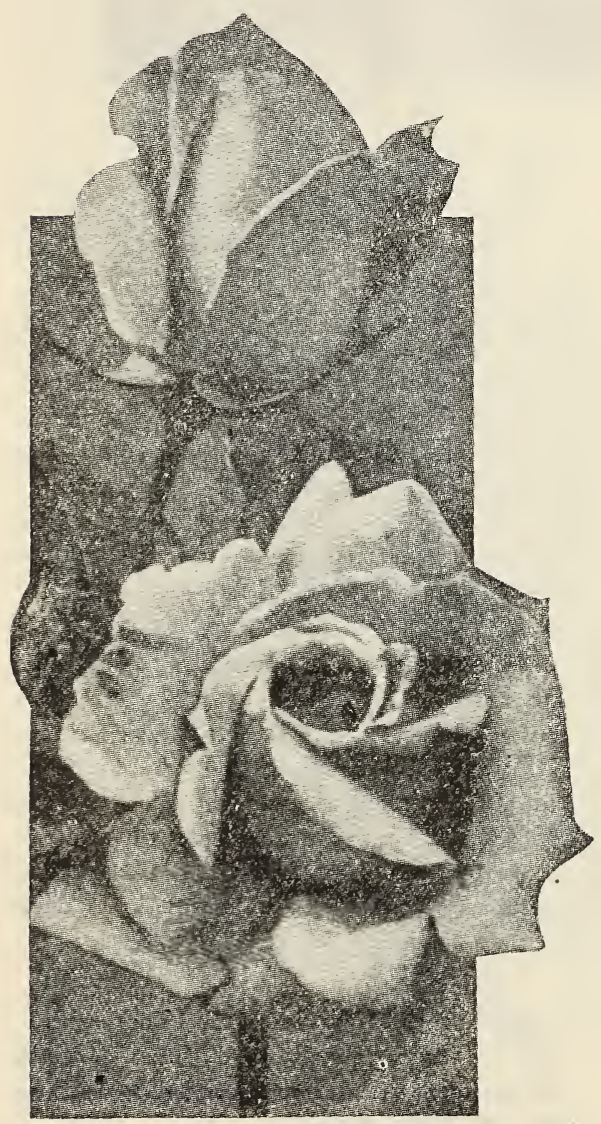

Mrs. Aron Ward

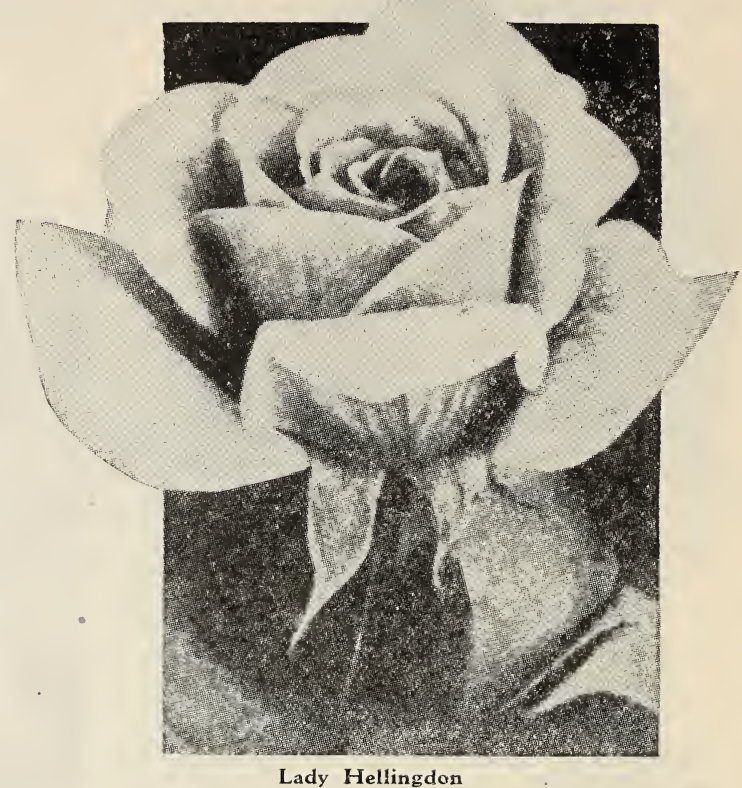

Lady Hellingdon

LADY HELLINGDON (Tea-Hybrid). Gyönyörï alaku uj szalmasárga rózsafaj. Virágai kitünő illatuak. 1 darab 90c; 10 darab $\$ 8.50$.

MRS. ARON WARD ('Tea-Hybrid). Folyton viritó tea-rózsa faj, remek, kecses, hosszu alaku bimbókkal. Virágja szine narancs-sárga és kitünő illatu. 1 darab 90c; 10 darab $\$ 8.50$.

MADAME EDOUARD HERRIOT. Ezen gyönyörü rózsa-ujdonság az 1913. évi rózsakiállitáson Londonban az arany serleget nyerte el. Remek szinezete és bámulatos erős növése, megnyerte a közönség tetszését. Szine mielött kinyilik, rézvörös, sárga, rózsaszin árnyalattal, mikor kinyilik, szinte rézvörös, lángszin és skarlát árnyalattal. Mivel szinét teljesen megnevezni senki sem tudta, igy hasonlitották ahoz a szinhez, mikor a fényes nap rézvörösre veti sugarait. 1 darab $90 \mathrm{c} ; 10$ darab $\$ 8.50$. 
JULIET. Ezen gyönyörü rózsa teljesen eltér a többi tearózsáktól az óriási nagy virágjánál fogva. Virág szine szirmok, külső széle rózsaszin, beljebb rézvörös, közepén pedig narancssárga. Virág nagysága kinyiltan 5-6 col átmérőben. 1 darab 90c; 10 darab $\$ 8.50$.

WILLOW'MERE. Ezen gyönyörü rózsát egy hollandi kertész állitotta elő és elöször a chicagoi kiállitáson lett a közönségnek bemutatva, ahol is az első dijat nyerte el. Szine bimbó korában skarlát vörös, a hegyén kissé világosabb árnyalattal, mikor pedig ki van nyilva, virágja csésze alaku, középen sötét sárga, szélein világos rózsaszinből láng-szinbe váltakozik. 1 darab 90c; 10 darab $\$ 8.50$.

\section{Tea-Hybrid Folyton}

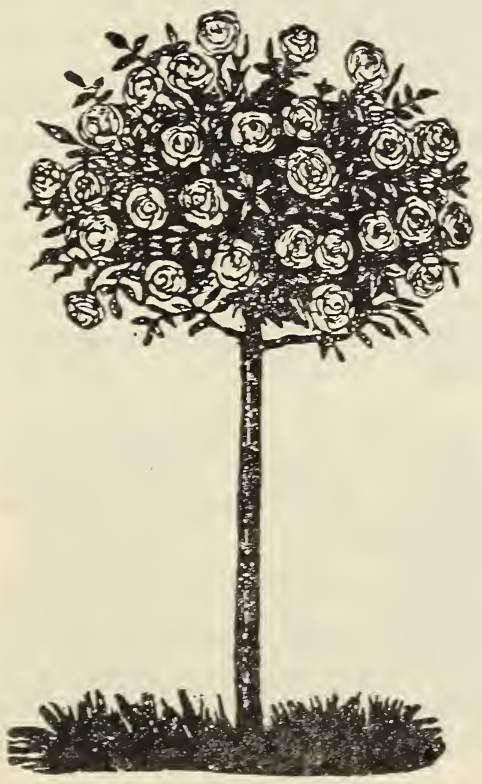

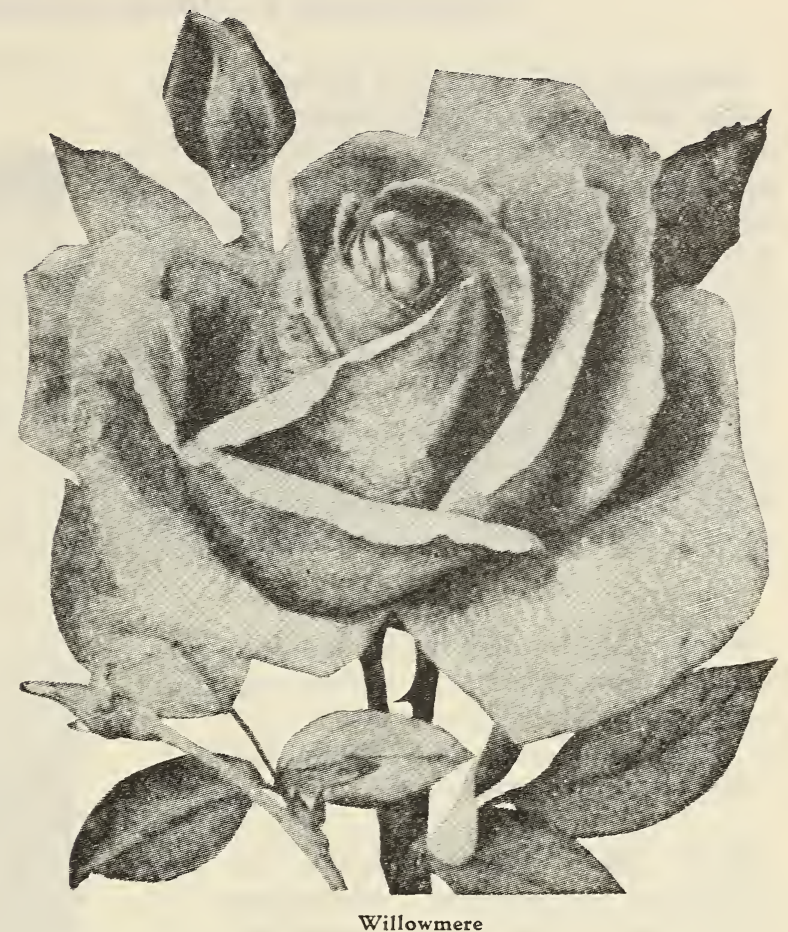

Virito Magastörzsü Rózsák

Örömmel adjuk tudomására az igen tisztelt vevőink. nek, hogy ismét szolgálhatunk magas törzsü rózsákkal, a legszebb szinekben. Magas törzsü rózsafáink 2 éves erőteljes példányok, 4-5 láb magas törzsökkel és bő gyökérzettel. A kiültetés első évében bő virágzást fejlesztenek.

MAGAS TÖRZSÜ RÓZSÁINK. A legszebb és a legujabb 15 külön faj a legremekebb Bordó, Piros, Rózsaszin, Fehér és Sárga szinekben. Darabja \$3.00; 10 darab $\$ 27.50$.

MAGAS TÖRZSÜ SZOMORU RÓZSÁKKAL szintén szolgálhatunk. Piros, Fehér és Rózsaszinü szinekben. Darabja $\$ 3.00 ; 10$ darab $\$ 27.50$.

Magastörzsü Rózsákkal csak bizonyos mennyiséggel szolgálhatunk, tehát azért kérjük az igen tisztelt vevőinket, aki óhajt ezen rózsát rendelni, az sziveskedjék rendelését korán beküldeni, mert már az elmult éveki rendelésekről tudjuk, hogy nem fog kerülni minden magas törzsü rózsa kedvelö vevőnknek. 


\section{REMONTANT TÉLÁLLÓ BOKOR RÓZSÁK.}

Telepünk egyik föágát a bokor rózsafák tenyésztése képezi. Ennek folytán rózsafa iskolánkból évente $30-40$ ezer nemesitett bokor- és. futórózsát hoznak forgalomba. Valamennyi eladásra kerüló bokor- és kuszórózsafáink 2 éves, jól elágazott példányok, dus gyökérzettel s már egy izben rózsa$\mathrm{fa}$ iskolánkban viritottak.

A TÉLI TAKARÁS. A bokor rózsafák téli betakaritásához használjunk trágyás szalmát, de ha ez nincs, falevél, vagy más egyéb is megfelel erre a célra.

\section{AMERICAN BEAUTY. Széles} körökben ismert, remek, mély rózsaszinü, karmazsinpirosba átmenö, illatos rózsa, szép állásu, nagy virágokkal. 1 darab 85c; 10 darab $\$ 8.00$.

GEO. ARDENS (Remontant). Tulajdonságai mindenféle tekintetben egyenlők az itt leirt Snow Queen-ével, mig az fehér, a Geo. Ardens szine pedig a legremekebb selymes rózsaszin. 1 darab 85 c; 10 darab $\$ 8.00$.

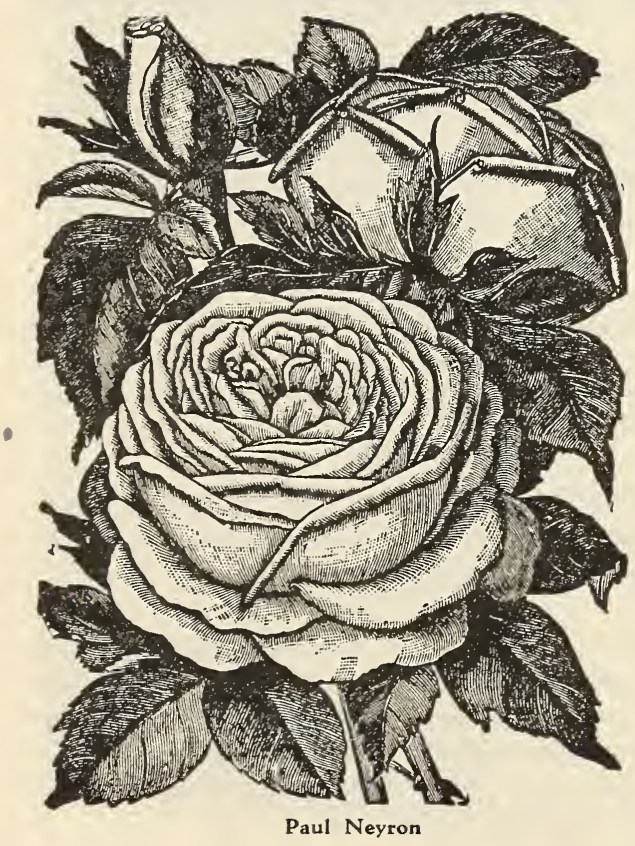

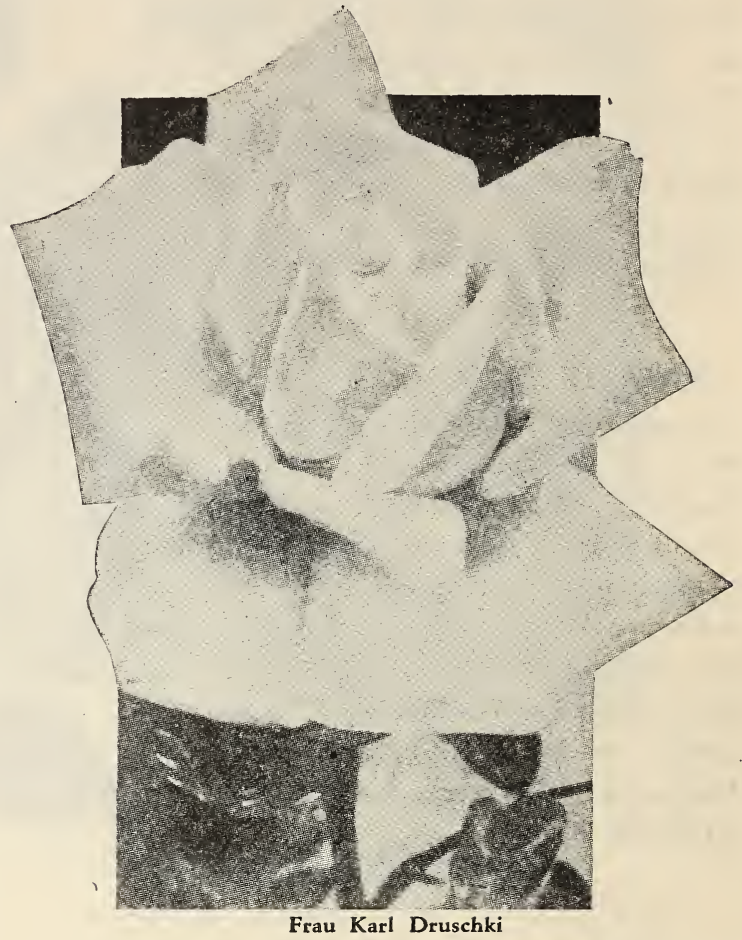

FRAU KARL DRUSCHKI, vagy SNOW QUEEN (Remontant.) Virága szine gyönyörü hófehér, a legcsekélyebb más árnyalat nélkül. Bimbói gyönyörü szép, hosszu, megnyult alakuak. Növése igen erőteljes. A Remontant vagy a többször nyiló rózsák között a legelső helyet foglalja el. 1 darab $90 \mathrm{c} ; 10$ darab $\$ 8.50$.

MRS. JOHN LAING (Remontant). Szép bokrokat fejlesztő rózsafaj. Bimbói gyönyörü szépek, hosszukás alakuak. Szine selyemrózsa szinü. Remek faj. 1 darab 85c; 10 darab $\$ 8.00$.

PAUL NEYRON. (Remontant.) Nagyon erős növésü. Virágai nagyok, mély rózsaszinüek és pompás illatuak. 1 darab $85 \mathrm{c} ; 10$ darab $\$ 8.00$.

Ha városában nincs express hivatal (Express Office), nagyon kérjük a legközelebbi város nevét adni, ahol van ezen hivatalok egyike. 


\section{TÉLÁLLÓ FUTÓ VAG Y KUSZÓ RÓZSAFÁK.}

Ezen ház- és rózsa fényképről a következőket irja egy new yorki vevőnk:

$$
\begin{array}{r}
\text { Ozone Park, N. Y., } \\
\text { Sept. 28, } 1926 .
\end{array}
$$

Tisztelt Uram:-

Itten mellékelve küldünk egy fényképet, azon Futó American Beauty rózsáról, amelyet önöktől hozattunk négy éve. A szom. szédok és a járó közönség, mind megállnak és tovább bámulják, amikor virágoznak és nagyon meg vagyunk velük elégedve.

\section{Tisztelettel}

\section{R. VARGA.}

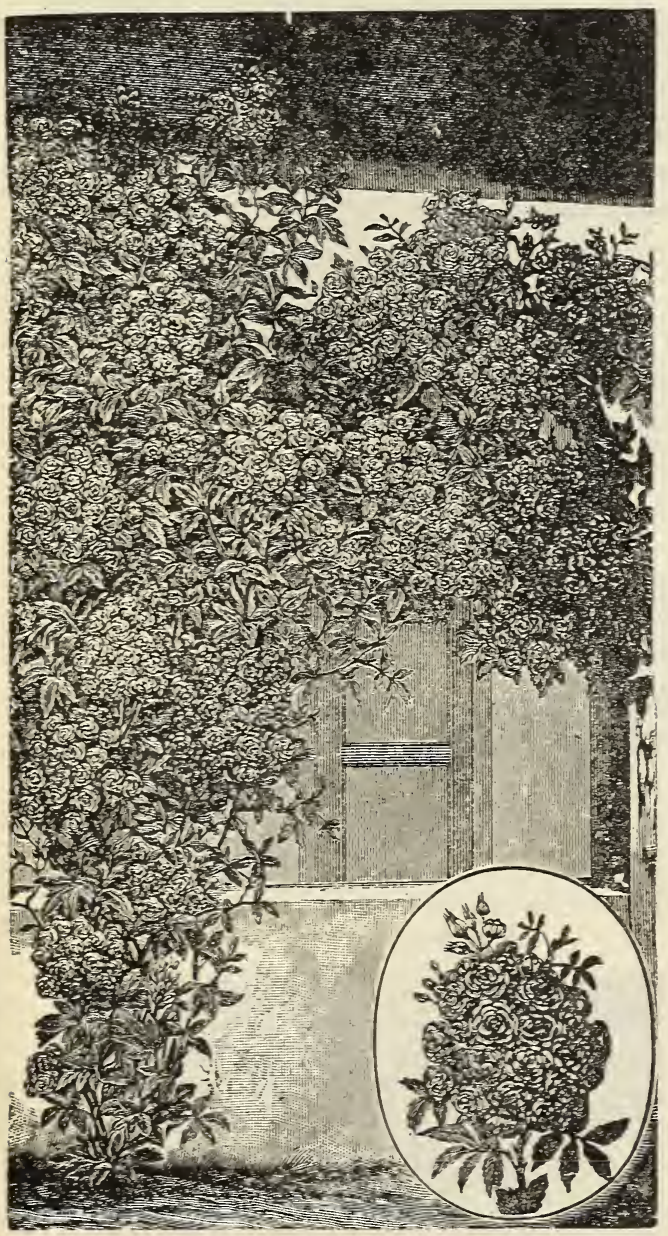

Crimson Rambler

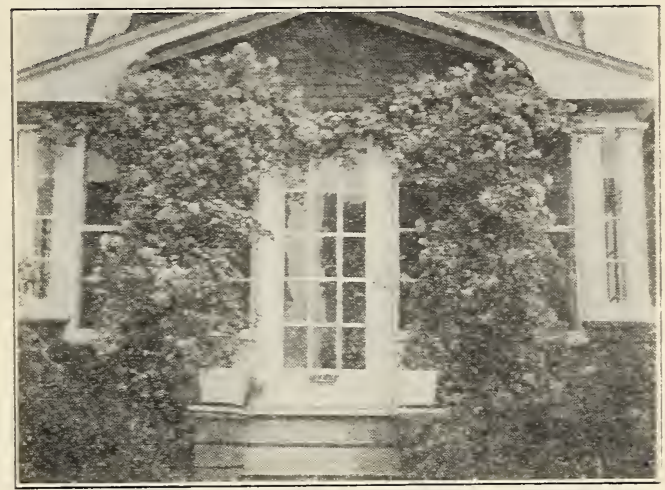

Futó American Beauty

Nagyon ajánlhatók porchok verandák, falak, stb. befuttatására.

FUTÓ AMERICAN BEAUTY. Ez egy magonc válfaja az ismert American Beautynak. Virágja gyönyörü skarlátvörös, bimbó alakja tearózsákhoz hasonló. Virágzása pe. dig nagyon eltérő az összes futó rószáktól, mert valamennyi futórózsa fürtökben hozza a virágot, ezen pedig minden virág külön hosszu száron jelenik meg, ennélfogva vágni is nagyon alkalmas. 2 éves nemesités. 1 darab 90c; 10 darab $\$ 8.50$.

CRIMSON RAMBLER. Vörös virágu futórózsa. Élénk vörös virágu, mindenki által ismert futórózsa, amelyen a virágok nagy fürtökben jelennek meg; egy 3 éves növény 300 ilyen virágcsomót is hoz. E faj gyors növése felülmulhatatlan erös, ültetésének évében hosszu hajtásokat fejleszt, amelyek a reá következö évben tele vannak virágokkal. 1 darab $80 \mathrm{c} ; 10$ darab $\$ 7.50$.

FOLYTONVIRITÓ CRIMSON RAMBLER. Szakadatlanul, egész nyáron át virágzó vörös virágu rózsafaj. Egy teljes virágzásban levő növényen alig látszanak ki a levelek és bámulatos nézni. Teljesen télálló. Növése igen buja és elegáns. 1 darab 90c; 10 darab $\$ 8.50$.

KÉK RÓZSA UJDONSÁG! Kék virágu futórózsa. (Blue Rambler.) Ezen faj a Crimson Rambler törzsfajhoz tartozik, virágjai viola szinbe menők. Igen erőteljes növésü. 1 darab 90c. 10 darab $\$ 8.50$. 


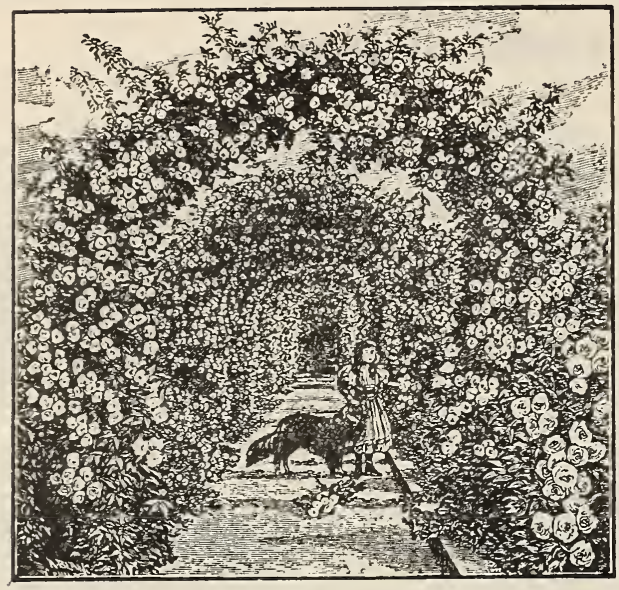

Pink Rambler Rózsa
PINK RAMBLER. Rózsaszinü virágu futó rózsa. Remek gyengéd rózsaszinü virágu futó rózsa faj, amely virágjait nagy fürtökben hozza virágzása idején. Virágzáskor a szépség és bájosság csodája. 1 darab 80 ; 10 darab $\$ 7.50$.

WHITE RAMBLER. Fehér virágu futó rózsa. Növése egyenlö a vörös virágu crimson Remblerével, csakhogy piros helyett ez hófehér virágu. 1 darab 80c; 10 darab $\$ 7.50$.

YELLOW RAMBLER. Sárga futó rózsa. Gyönyörü sárga szinü fürtökben virágzó futó rózsa faj. Egyes virágai nagyobbak, mint az anyafáé és illatosabbak. 1 darab $80 \mathrm{c} ; 10$ darab $\$ 7.50$.

\section{DISZCSERJÉK ÉS BOKROK.}

A diszcserjék otthonunknak vagy kertjeinknek állandó diszéül szolgálnak és egyesek pompás virágzásukkal hálálják meg a reájuk forditott fáradtságot. Minthogy a diszcserje tenyésztése faiskolánk egy oly főága, amelyből százezrek kerülnek tőlünk forgalomba, képesek vagyunk a legmesszebbmenő igényeknek is megfelelni.

$\mathrm{Az}$ alábbi diszcserje fajaink 2-3, némelyek 3-4 láb magas, erős példányok és dus gyökérzettel birnak. Szállitásuk csak Expresszen eszközölhető.

\section{Amygdalopsis.}

\section{AMYGDALOPSIS ROSEA}

FL. PL. Tavasszal, mielött a levelek kijönnének, az ágak tele vannak selyem rózsaszinü virágokkal. A létező legszebb diszcserjéink egyike; $2-3$ láb magas. 1 darab $75 \mathrm{c}$; 10 da$\mathrm{rab} \$ 6.50$.

\section{Berberis-Sóska Cserje.}

\section{BERBERIS THUNBERGI.}

Igen csinos cserje, halavány sárga virágokkal, amelyeket őszön piros gyümölcsök követnek. Levélzete nyáron zöld, ősszel pedig átváltozik gyönyörü barna pirossá. Nagyon alkalmas ezen cserje ugy sövényeknek, mint ház alá és porcsok körül. Amerikaszerte, óriási mennyiségben használják lotok elválasztásának, sövénynek pedig az első helyet foglalja el gyönyörü, szin változó levelei miatt. 2 láb magas példányok. 1 darab 35 c; 10 darab $\$ 3.00$.

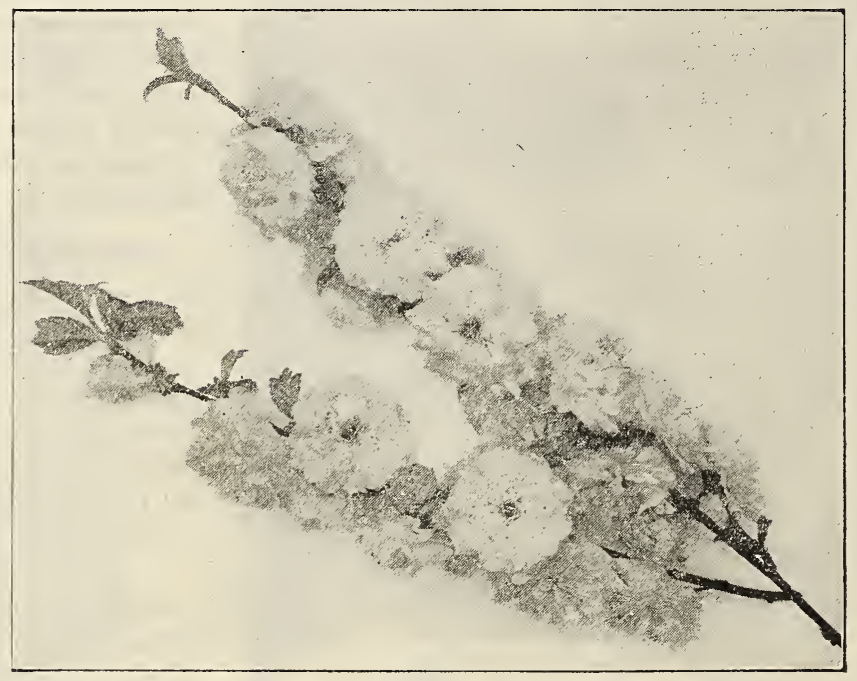

Amygdalopsis

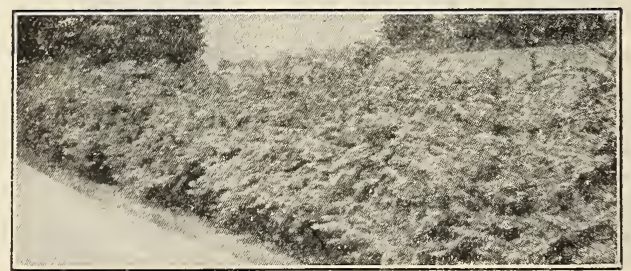

Berberis (Sóska Cserje) 


\section{Buddleia - Folytonviritó Orgona}

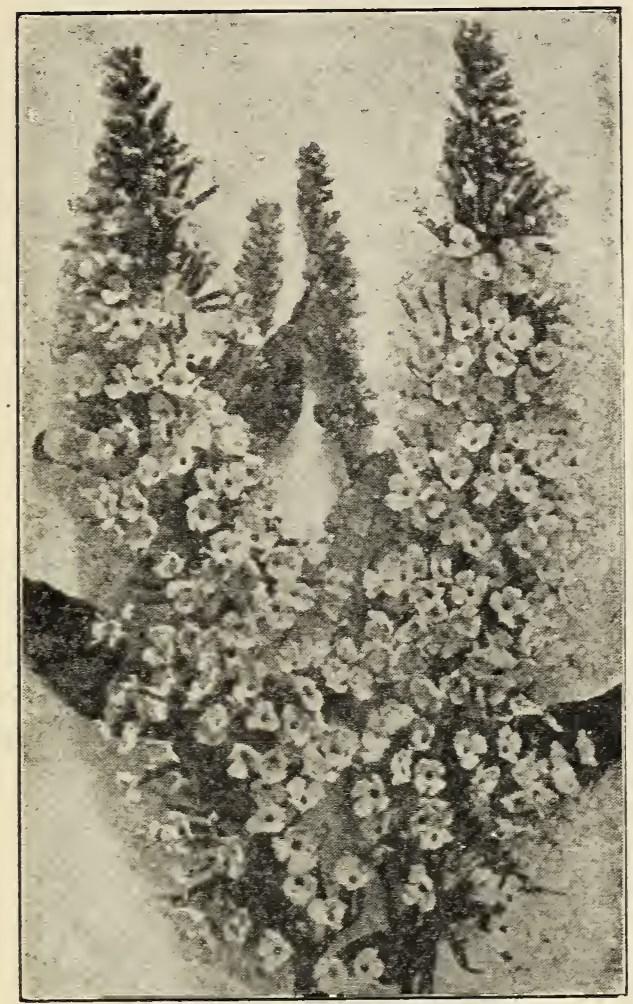

Nyári Orgona

\section{Nyári Orgona}

NYÁRI ORGONA vagy SZELENCE. Remck ujdonság, a legkeresettebb az összes virágeserjék között. Virágja alakja az orgona virághoz ha sonló, csak a virágfürtök jóval hosszabbak, néha 1 láb hosszura is nőnek és a kinyult ágak hegyén csüngnek. Virágja szine ibolya kék, első éve.r 4-5 láb magasra nő. Julius hónaptól egész ni. deg őszig tömve remek alaku virágokkal. 2 éves erös példány. 1 darab 50c; 10 darab $\$ 4.50$.

\section{Cytisus - Sárga virágu akác}

CYTISUS LABORNUM. Magasra növő cserje sárga, lecsüngő virágokkal. Virágja állása ép̣̂en olyan, mint a fehér virágu akácfáé és ez is feltő olyan magasra, csak ennek tüskéje nincs és a héja a fájának mindig zöld. 1 darab $60 \mathrm{c} ; 10$ da$\mathrm{rab} \$ 5.00$.

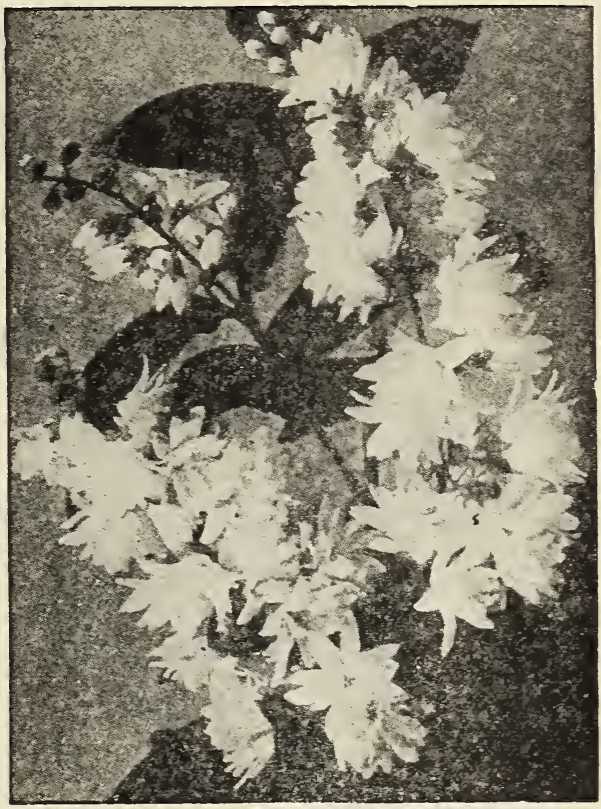

Deutzia

\section{Deutzia}

DEUTZIA CRENATA FL. PL. Igen kedves középmagas növésü diszcserje, fehér virággal, ró. zsaszinnel ágyalva a szirmok szélei. Szép peldànyok. 3-4 láb magas. 1 darab $50 \mathrm{c} ; 10$ da $\mathrm{rab} \$ 4.50$.

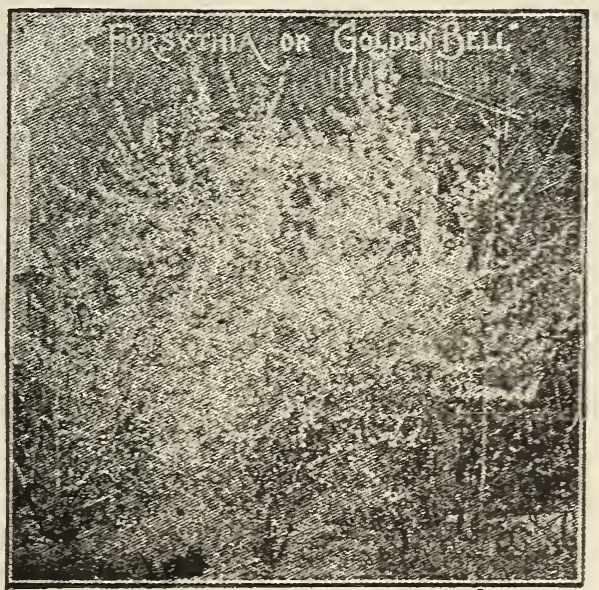

Forsythia

Forsythia - Harangvirág cserje

FORSYTHIA INTERMEDIA. Kora tavasz. szal, mielött a levelek kijönnének, a cserje tele van aranysárga lecsüngő virágokkal. 3-4 lab magas. 1 darab 50c; 10 darab $\$ 4.50$. 


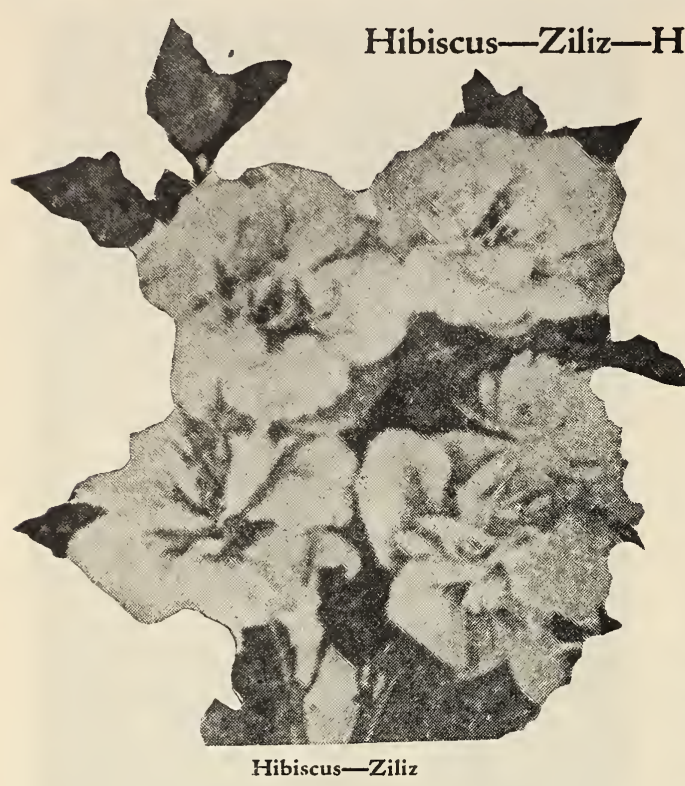

HIBISCUS SYRIACUS FL. ST. Középmä gasságu cserje. Nagymennyiségü lila, halavainy ibolyapiros és fehér szinezetü virágokkal elárasztva. Virágjuk alakja hasonlit a tózsákhoz. ju lius elejétől egész október hónapig viritanak. 2-3 láb magas. 1 darab 50c; 10 darab $\$ 4.50$.

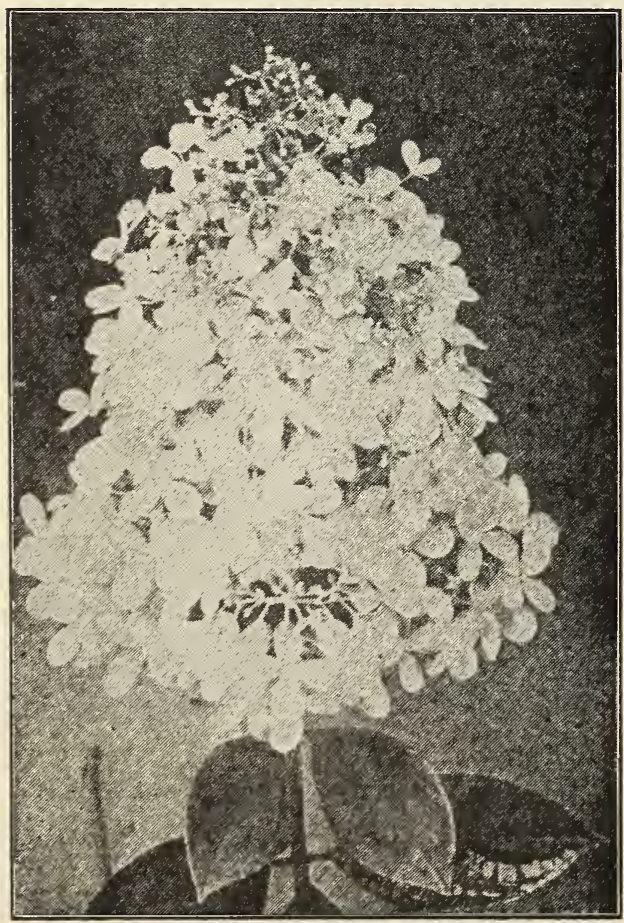

Hydrangea-Hortenzia
HYDRANGEA PAN. GRANDIFLORA. Re mek, fehérből rózsaszinbe átmenő nagy lalidi: alaku virágokkal. Gyönyörü cserje, különösen nagyon alkalmas porchok körül ültetve. Amerika. szerte nagy mennyiségben használják ugy etre, mint parkokba vagy grupokba ültetve és ágyak szegélyének használva. Lehet akármilyen magas ra növelni, akár mindig alacsonyra tartani. metszés által. Minden tavaszon vissza kell metszeni s pe. dig ha alacsonyan, bokrokra akarja tartani, akkoz 2 szemre minden ágat, ha pedig magasabbra, ak kor 4-5 szemre. 2-3 láb magas. 1 darab 6ik; 10 darab $\$ 5.50$.

\section{Lonicera - Bozótcserje}

LONICERA GRANDIFLORA. Általánosan kedvelt, május és juniusban virágzó, magas diszcserje. Virágai világos rózsaszinüek, fürtökijtı jelennek meg az ágakon és oly bőven hozza a : :rágokat, hogy mikor virágzik, még a leveleket sem lehet látni a virágoktól. 2-3 láb magas. 1 darab 50c; 10 darab $\$ 4.50$.

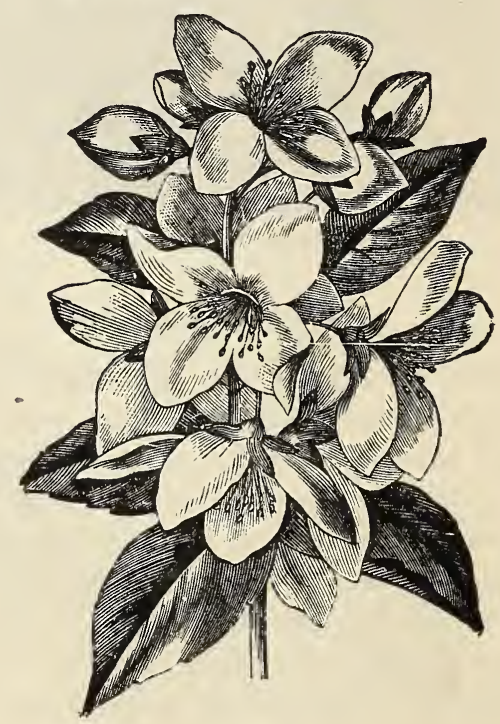

Jázmin

\section{Philadelphus - Jázmin}

PHILADELPHUS GRANDIFLORA. Lom:csoportokban nélkülözhetetlen cserjefaj, bájos nagy fehér, illatos virágdisszel és gyönyörü lon:bozattal. Nincs az a magyar ember, aki ezen csurjét ne ismerné, hiszen még egy kedves magyar dalban is meg van, hogy: "Jázmin bokor kihaj. tott az utcára." Igen erős, idővei óriási bokor:á fejlödik és 10-12 láb magasra is fölemelkecirk. mikor pedig virágzik, szaga mértföldekre is èız: hetö. $2-3$ láb magas. 1 darab $50 \mathrm{c} ; 10$ darab $\$ 4.50$. 


\section{Sambucus - Bodza, sárga levelü}

SAMBUCUS RACEMOSA. (Fürtösbodza.) Vi. rágjai kitünő illatuak. Ezen cserje ugyan neverci! nagyon közönséges cserjének hangzik, mert Miegyarországon a bodzát ki sem tudják irtani, de ezen bodza egészen más, gyönyörü aranysárgák a levelei és egész nyáron át remek látványt nyujt $2-3$ láb magas. 1 darab $50 c$; 10 darab $\$ 4.50$

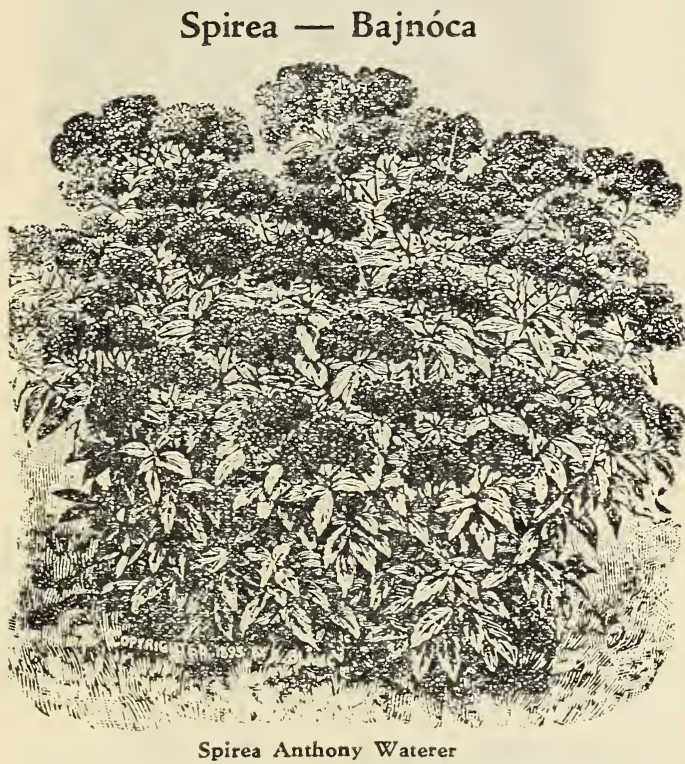

SPIREA ANTHONY WATERER (Piros Virdgu Bajnóca.) Soha nem magasabbra, mint 2-3 láb magasra növő és nagy bokorra fejlödő remek piros virágu cserje. Junius hónapban kezdi mé virágzását és hideg ószig szakadatlanul virágzik 2 láb magas. 1 darab 60 c; 10 darab $\$ 5.00$.

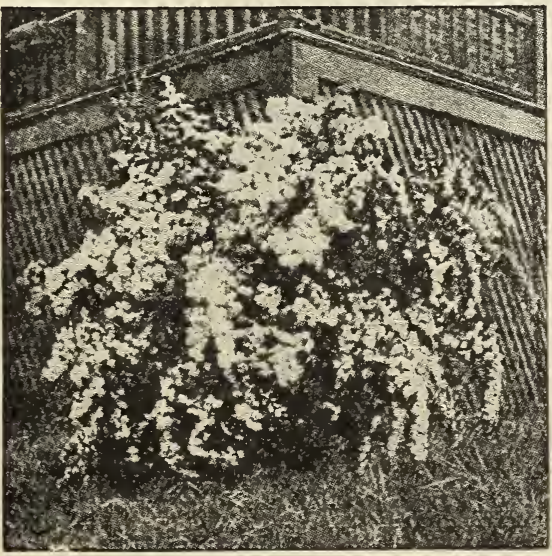

Spirea-Bajnóca (Van Houtte)
SPIREA VAN HOUTTE. Gyönyörü, hófehér virágu cserje. Virágzáskor egészen el van borit. va remek, hófehér virágokkal. Egyike a legszeb. beknek porchok (verandák) körül, vagy eleven sö. vények ültetésére. Akár idomitják, akár nem, dc pompás alakra fejlődik. 2-3 láb magas. $1 \mathrm{da-}$ rab 50c; 10 darab $\$ 4.50$.

\section{Syringa - Szelence vagy Orgonafa}

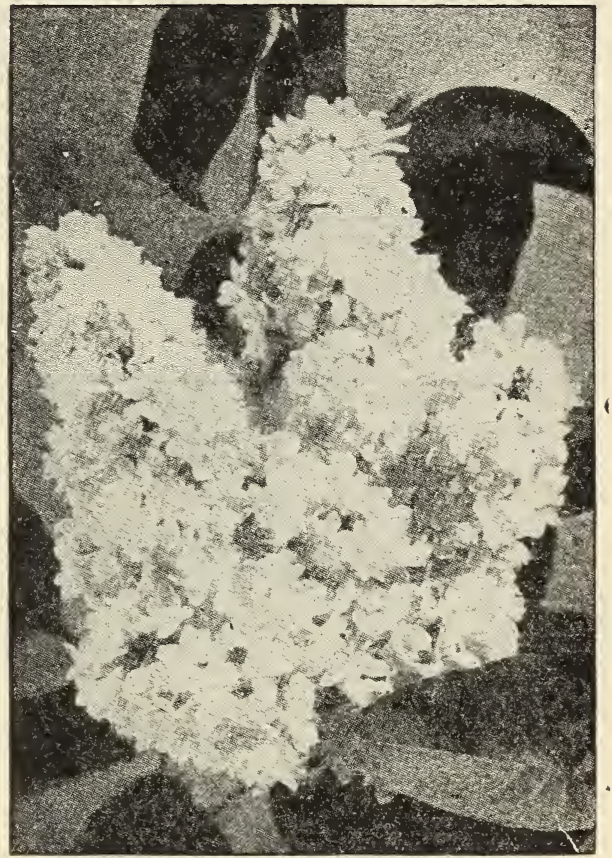

Syringa-Szelence vagy Orgonafa

SYRINGA. Tagadhatatlanul a legkedvesebb és illatosabb virágu diszcserje. Kora virágzásaval egyszersmind a tavasz eljöttét hirdeti. Ezen gyo nyörü cserjének nem szabadna hiányoznia egy udvarból sem. Gyönyörü alaku, magasra növő cserje és virágja majdnem még hó van a földön, mı. kor megjelenik a bokrokon. Teljes virága pirus fehér, rózsaszin és lilakék szinekben. 2-3 láb ma. gas. 1 darab $75 \mathrm{c} ; 10$ darab $\$ 7.00$.

\section{Symphoricarpus}

Junius-juliusban virágzó, kedvelt diszcserje apró rózsaszinü virágokkal, melyek teljesen elboritják az egész növényt. A virágok lehulltával pedig gömbölyü hófehér bogyócskák jelennek meg a nö. vényen fürtökben, melyek késő őszig rajta marad. nak. 2-3 láb magas. 1 darab 50c; 10 daraí $\$ 4.50$. 


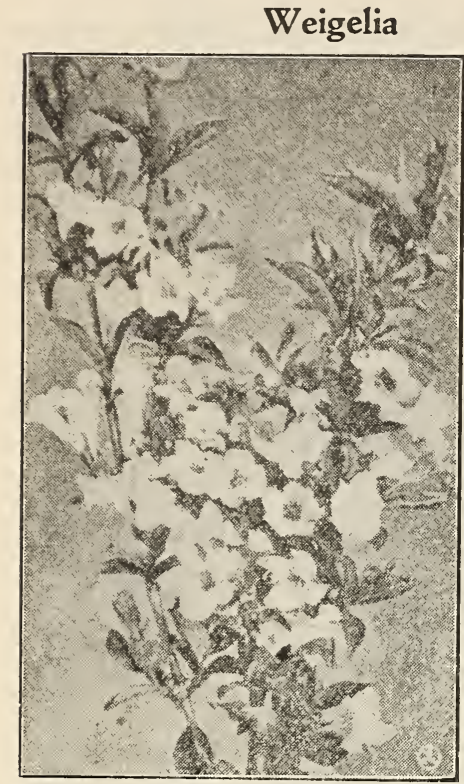

WEIGELIA. Gyönyörü vi rágcserjc. ' $v i$ rágzása idt jén az ágak telve vanuak. csőalaku vi. rágokkal. Az amerikaiak el sem tudnak képzelni egy házkörüli $\dot{k}$ ültetést ezen cserje nél. kül. Julius. tól egészen a hideg ósz ig szakadiatlanul viràg. zik. Virás. ján kivüi a levélzete is oly pompa. san diszıt. hogy ahová ezen cselje van ültetve, ott a szépnek nincs hiánya. Rózsaszin és piros szinekben. 2-3 láb magas. 1 darab 60 c; 10 da. rab $\$ 5.00$.

TAMARIX AFRICANA. Igen ajánlható, szép cidrusszerü cserjefaj. Különösen élösövènynek van ültetve, akkor 1 láb távolságban kell ültetni $\dot{c s}$ a leggyönyörübb élösövényt képezi, nyirni pedig. bármily alakban lehet. $2-3$ láb magas. 1 darab $60 c ; 10$ darab $\$ 5.50$.

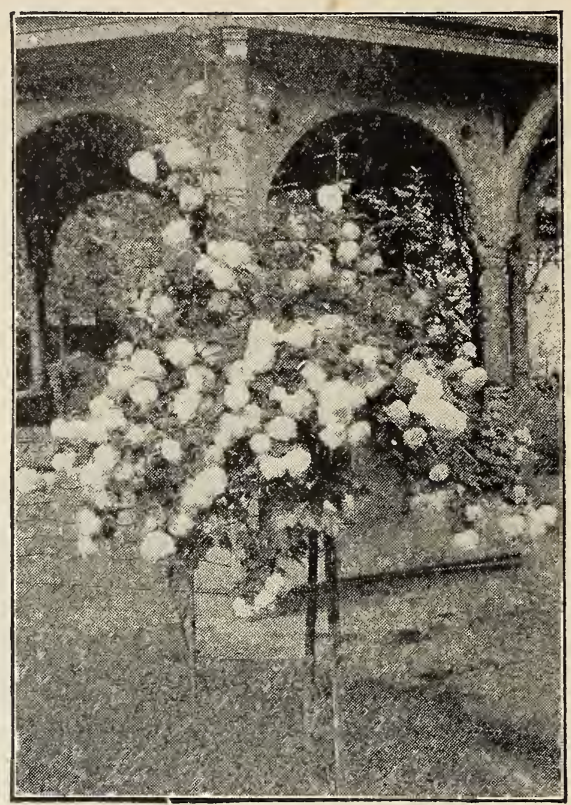

Labdarózsa

VILBURNUM STERILE. Gyönyörü szép virágcserje, amely egyetlen kertböl sem hiányzik. A valódi labdarózsafa. Ezen cserje tagadhatatlanu! a legismertebb egész Magyarországon. Virágził juniustól egész julius végéig. Idővel $10-15$ lál magasra is megnỏ. $2-3$ láb magas. 1 darab ouc; 10 darab $\$ 5.00$.

\section{ÉVELŐ KUSZÓNÖVÉNYEK}

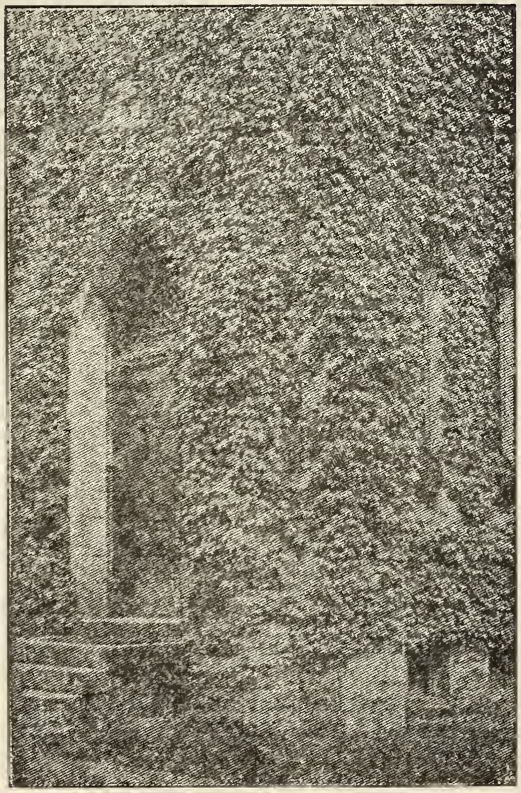

Nemes Vadszölö
Lakóházak, porchok, lugasok, keritések, stb. befuttatására igen szép kuszónövények és cserjék. Ahova ezen növények ültettet. nek, ott a régi föld kiemelendỏ és igen táp. dus réti föld és homok-vegyülékkel póto. landó.

\section{Ampelopsis - Vadszőlő}

NEMES VADSZóLö. Magától kapasz kodó, falak befuttatására, általánosan is mert apró levelü nemes vadszőlö, meiyet kastélyok és templomok befuttatására hasz. nálnak. Levélzete összel csodaszép sárga, piros és biborszinü árnyalatokban ragyo 1 darab 50c; 10 darab $\$ 4.50$.

KöZÖNSÉGES VADSZÖLó. Lugasok és porchok befuttatására igen alkalmas. Rendkivül diszitő hatásu. Ósszel a leveleł barna-piros szinbe változnak át. 1 darab 40 c; 10 darab $\$ 3.50$. 


\section{Aristolochia - Gégevirág}

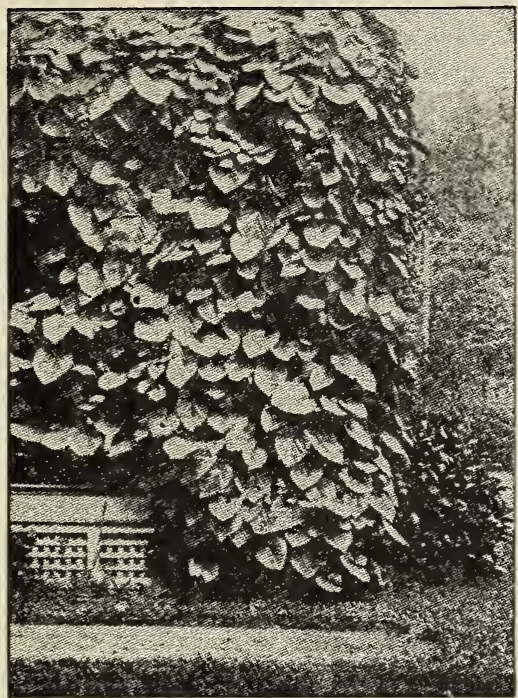

Aristolochia-Gégevirág

ARISTOLOCHIA SIPHIO. Nagy levelü zégevirág, pipa alaku virágokkal. Levelei nagysăga néha $12 \mathrm{col}$ átméröben. Egész nyáron át haragos zöld, a legkeményebb télálló kuszónövény. 1 darab $60 c ; 10$ darab $\$ 5.50$.

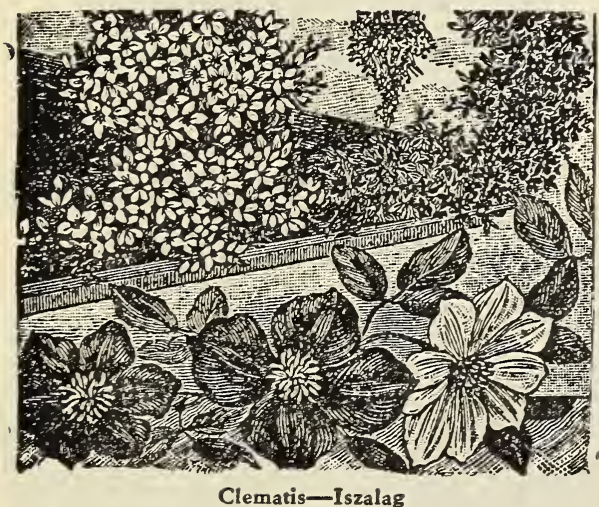

\section{Clemantis - Iszalag}

CLEMATIS HYBRIDA. Gyönyörü kuszó ni vény, lila-kék, fehér és biborpiros szinü, nagy, pompás virágokkal. Mivel a szinüknél fogva az amerikai nép nagyban veszi és a három különbö. ző szint: piros, fehér, kéket épp ugy szin szerınt ülteti, mint ahogy az amerikai nemezeti szin. A három palánta néhány év alatt 20-30 láb por. csot is betakar. 1 darab $80 c ; 3$ darab különböző szin \$2.25.
CLEMATIS PLANICULATA. Augusztus, szep. temberben virágzó kuszó cserje, kitünő illattal, középnagy, hófehér virágokkal. Mikor virágzik, szaga mértföldekre is érezhető, virágzik 5-6 hèts és mikor már virágja megszünt, akkor meg a nasgvak pehely alakban hetekig szinte különös icatványt nyujtanak. 2 éves. 1 darab $50 \mathrm{c} ; 10$ da. rab $\$ 4.00$.

\section{Glycine vagy Kékakác}

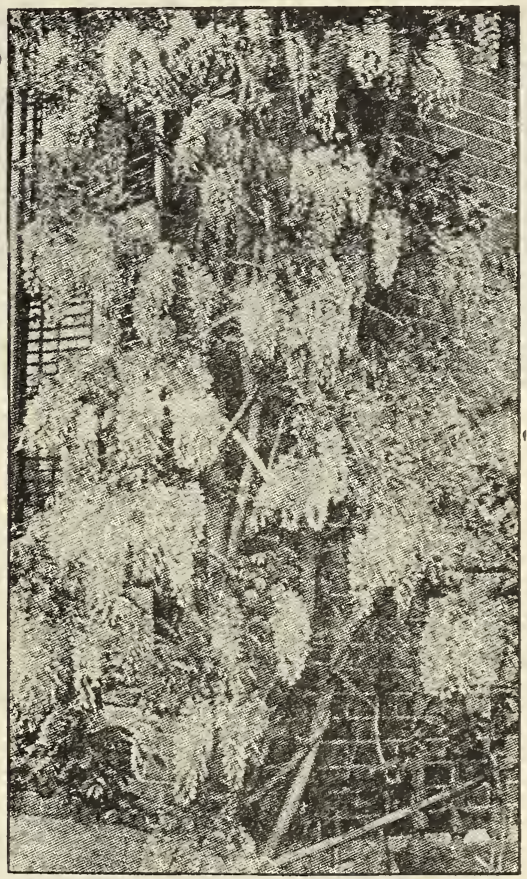

Glycine vagy Kékakác

GLYCINE vagy KÉKAKÁC. Általában ismurt kinai kẻk akác, a legszebb kuszó cserjék egyike, hosszu, fürtös, kellemes illatu virágokkal. A lc\& alkalmasabb porchok (verandák) befuttatásáia. 2-3 èves korában 10-15 láb hosszu indákat is hoz egy nyáron át, mikor pedig virágzik, az vala. mi mesés látvány. 1 darab $50 \mathrm{c} ; 10$ darab $\$ 4.50$.

\section{Hedera - Repkény}

HEDERA HELIX. Pompás, örökké zöld levcil. zetü futó növény. Különösen falak vagy fák befuttatására nagyon ajánlható. 1 darab 30c; 10 darab $\$ 2.50$.

\section{Lonicera - Futólánc}

LONICERA HALLIANA. Tiszta és sárgás fehér, nagyon kellemes illatu virágu futó cserje. Egész nyáron át folyton virágzik. Virágjának illata oly erős, hogy mértföldekre is érezhető. Áz angol (Honeysuckle) nevét is onnan nyerte, hozy illata oly édes és kellemes. Verandák vagy purchok befuttatására egyike a legszebb futó viraguk. nak. 2 éves. 1 darab 35c; 10 darab $\$ 3.00$. 


\section{SÖVÉNY CSEMETÉK}

Élö sövények a ház elött, a ház körül vagy ut:a hosszat, szépen idomitva (vágva), nagyban emrelik ugy a ház szépségét, mint értékét. $\mathrm{Az}$ alábbi fa jok azon csemeték, amelyek a legjobban megfelelnek házkörüli használatra, amelyek ugy levélzetükkel, mint bájos virágaikkal elragadó, szép külsőt adnak a ház tájának.

\section{Ligustrum - Nemes fagyalcserje}

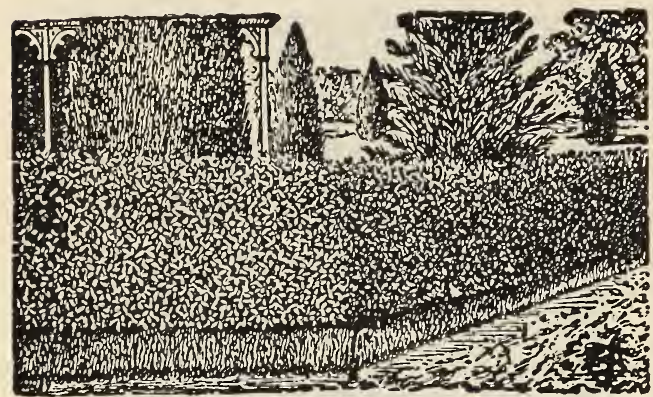

Nemes Fagyal Sövėny

NEMES FAGYAL SÖVÉNY. Nagyban inasz nàlt ugy városokban, mint kint a vidékeken. Örökzöld, fényes levélzetü, egyenes és tömött nö. vésü sövény cserje. Kitünően lehet idomitani (vágni) bármiféle alakra. Házát értékesitent és háza környékét pedig disziteni, semmivel scm tudja jobban, mintha ezen cserjéból szabályos sö. vẻnyt ültet. 2-3 láb magas, bokros példáns ok. 10 darab $\$ 1.50,100$ darab $\$ 10.00$.

\section{Berberis - Japán Sóskacserje}

Remek sövényt alkotỏ cserje faj, lecsüngő ágákkal, amelyeken sok sárga virágocska jelenik $m t_{t}$ a nyár folyamán. Összel pedig tömören vérpiros bogyók diszitik, melyek egész télen át rajta csü: nek, mely gyönyörü látványt nyujt. 2 láb magas 1 darab 35c; 10 darab $\$ 3.00 ; 100$ darab $\$ 25.00$.

\section{VIRÁGHAGYMÁK ÉS VIRÁGGUMÓK.}

Valamennyi virághagyma és gumó a homokos talajt szereti; márciustól junius elejéig ültethutỏk. $A z$ alább felsorolt legismertebb virághagymák és vi rággumók könnyen tenyészthetők, maguktól szaporodnak és ezáltal csak az első beszerzésük kerül pénzbe. Ezen virághagyma és gumó-fajok őssze! a földböl kiveendők és fagymentes, száraz helyen att eleltetve, tavasszal ujra elültetendők.

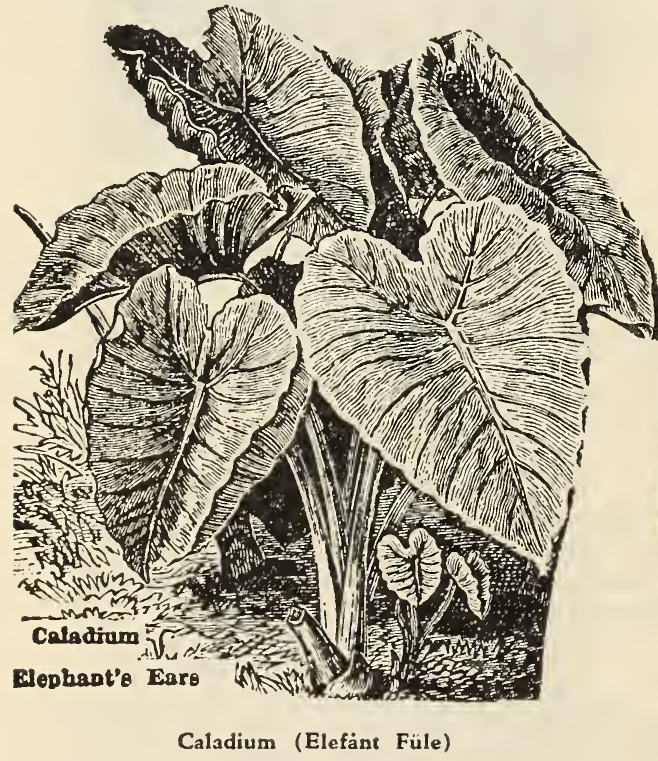

CALADIUM ESCULENTUM. Óriási paizs levelü disznövény. Könnyü talajban, árnyas t.elyen és elegendö nedvesség mellett ezen növin; leveleit óriási méretekre fejleszti. 1 darab 35\%; 10 darab \$3.00.

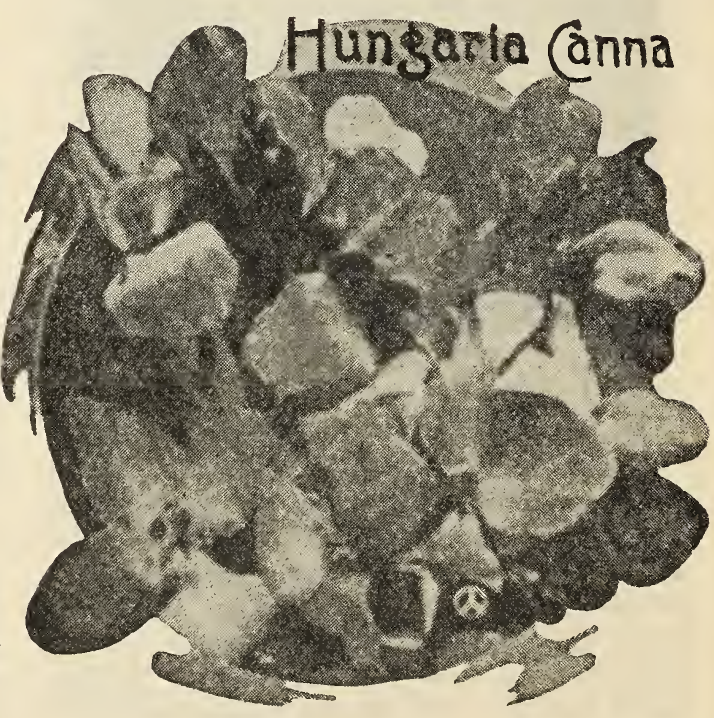

Canna Hungaria 


\section{Hungaria Canna}

HUNGARIA CANNA. Ezen Canna-ujdonság Magyarországon találtatott föl, azèrt van Hunguria-nak elnevezve. Óriási virágu, gyönyörü :ócsaszinü Canna. Szine nagyon hasonlit az usvire. vezett Paul Neyron rózsa szinéhez. Ha csoportokba (grupokba) van ültetve, szebbet képzelni sum lehet. Azonfelül porchok elé, vagy házaink körül a legalkalmasabb. 1 darab 30c; 10 darab $\$ 2.50$.

\section{Cannák (Kannák)}

CANNA INDICA. Impozáns kerti levęi és roppant virágbőségü diszvirág. A legremeliebb szinváltozatban. Azonfelül egyes fajoknak syö nyörü sötét-vörös levele nagyon pompás látvài.yt nyujt ugy grupokban, mint porchok elött. Lia." ható a következő szinekben: Piros, sárga, rúzsaszin, tarka és barna-vörös levéllel. 1 darab $25 \mathrm{c}$; 10 darab $\$ 2.25$.

\section{Györgyinák}

TENYÉSZTÉSE: A györgyina-gumókat nèn elöbb, mint május 1-én ültessük ki szabadỉa. Lehetőleg homokos földet adjunk a tövéhez, isert akkor korábban megkezdi a virágzást. Össz:l ki. szedjük és pincében tartjuk.

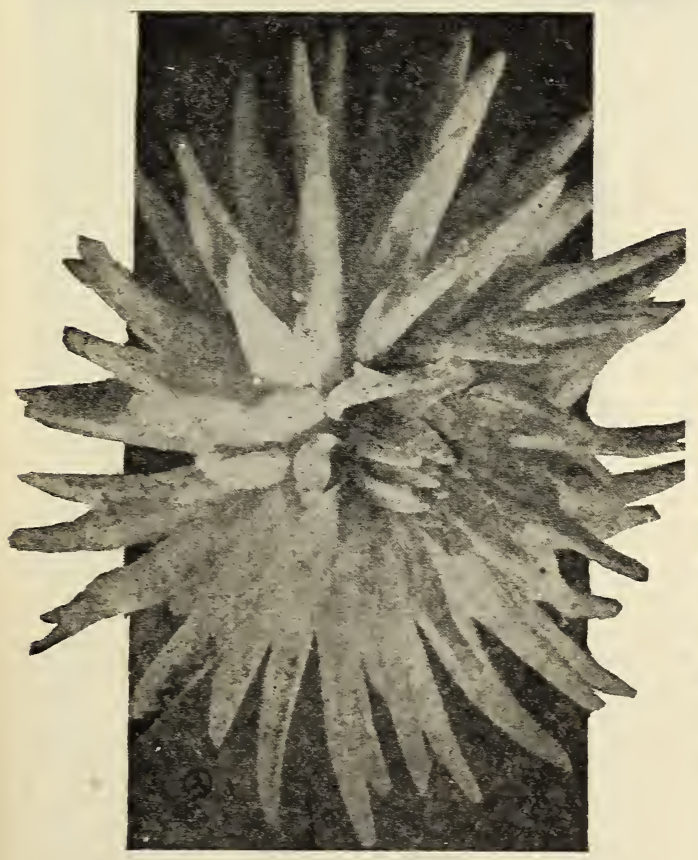

Györgyike Kaktuszvirágu

GYORGYIKE - KAKTUSZVIRAGU. Ezen gyōnyö. rū virág ujdonság., gyönyörū szinezetével és remek virág allásánál fogva már a legtisztább rózsákat is felülmulja. Virág szirmai lazák, hosszuak és kissé gōndörek. A kak. tusz virágtól alig lehet megkülönböztetni. Piros, sárga, kék és rózsaszinekben. I darab 30c; 5 darab òt szinben $\$ 1.25$.
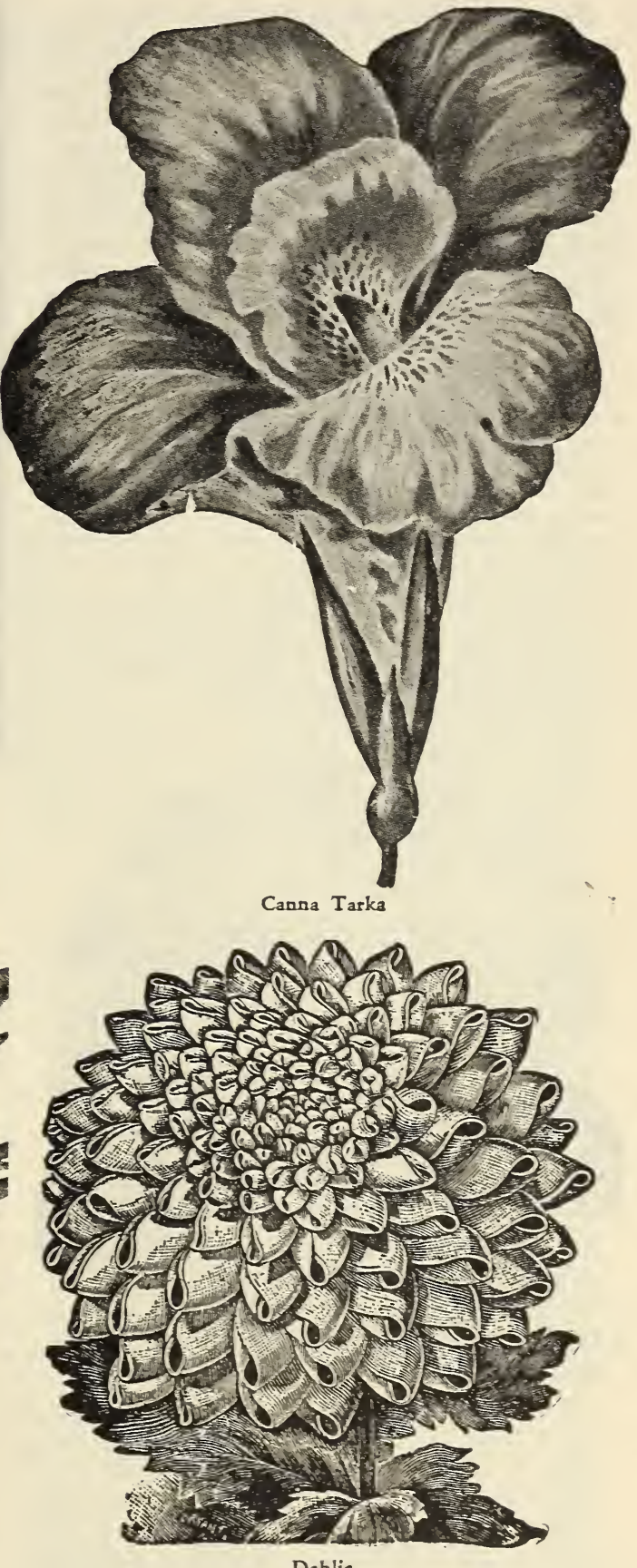

Dablia

\section{Dahlia}

DAHIIA VARIABILIS. (Györgyike). Ezen virágfa. jok szépségük folytán mindenüt meghóditották a virágked. velöket. A leghálásabban virit minden gumós virágnemek között. Gyönyörū teljes virágu, piros, fehér, sárga, rózsa. szin és kék szinekben. I darab 25c; 5 darab, vagyis ô szinben $\$ 1.00$. 
BRONZ KIRÁLY GYÖRGYINA. Ezen gyö. nyörü györgyina saját fölfedezésünk és nem több még, mint 5 éves, máris ugy elszaporitottuk, hıgy most a jövő tavaszon, több mint tizezer áll : «n. delkezésünkre, vevőinket kiszolgálıı. Ilyen sıınü györgyina még ez ideig nem létezett és ez a: a szin, amelyet minden virágnál legjobban kedvel a tisztelt közönség: az ugynevezett tronz, vagyıs a vörös réz szin és pedig oly tökéletes és tiszta $s>1:$, hogy első látásra bárkinek is megnyeri a tetszését. Szóval ezen szin legjobban hasoniii a napsugarak szinéhez, mely néha oly gyönyöri szinben fest esti nyugváskor. Virágszirmuk tágak és nagyok, szabályosan elhelyezve, a virág nagysaga néha 610 hüvelyk átmérőben, virágszárai szinte 1 ès fél, 2 láb hosszu és ez is nagyban emeli értékét, inert nagyon alkalmas diszitésre. Akik közel laknak. nagyobb városokhoz vagy forgalmi utakhoz, azok vagyont csinálhatnak virágjából, mert mikor a nagy virágkereskedök más szinü györgyinákért 25 centet fizetnek tucatjáért, akkor ezen fajért fizetnek 5-6 centet, de néha 10 centet is adnak darabjáért. Az elmult nyáron volt nukink egy hold föld terjedelmen, amit volt is sok tisztelt vevőnknek alkalma látni, látogatásuk alkalmával, és mi arról eladtunk több mint 10,000 viragot, átiag 5 centért darabját. Postán bérmentve darabja 50c; 10 darab $\$ 4.00 ; 100$ darab $\$ 30.00$.

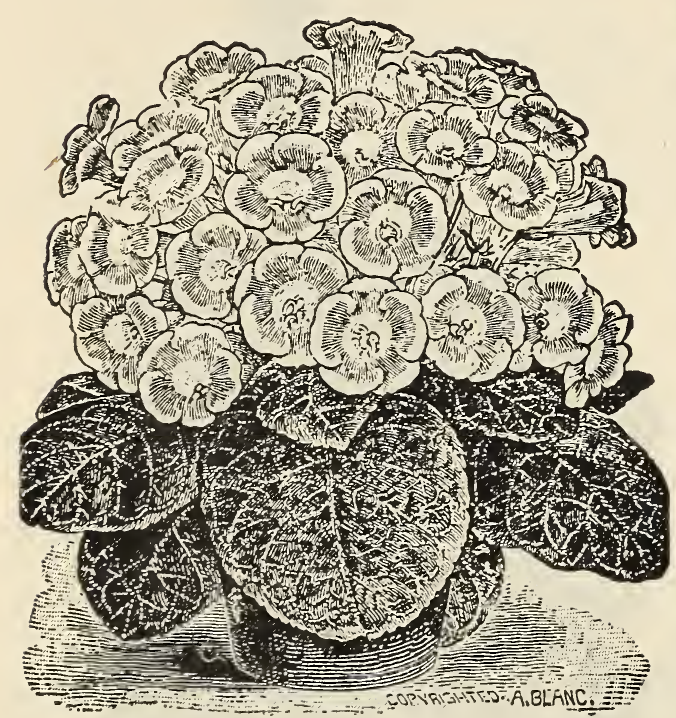

Gloxinia

\section{Gloxinia}

GLOXINIA. Egyike a legszebb nyári virágoknak. Gyönyörü többszinü, töic^eralaku virág. ja, nagy, gömbölyü viaszkos leveiti kertjeinkben pompás látványt nyujt. Könnyü, kövér fekete földet szeret. A gumókat május 15 ćn ültessük ki. Szobában cserepekben is könnyen tenyészik. Kap. ható csak vegyes szinekben. 1 darab 35c; $10 \mathrm{da}$ rab $\$ 3.00$.

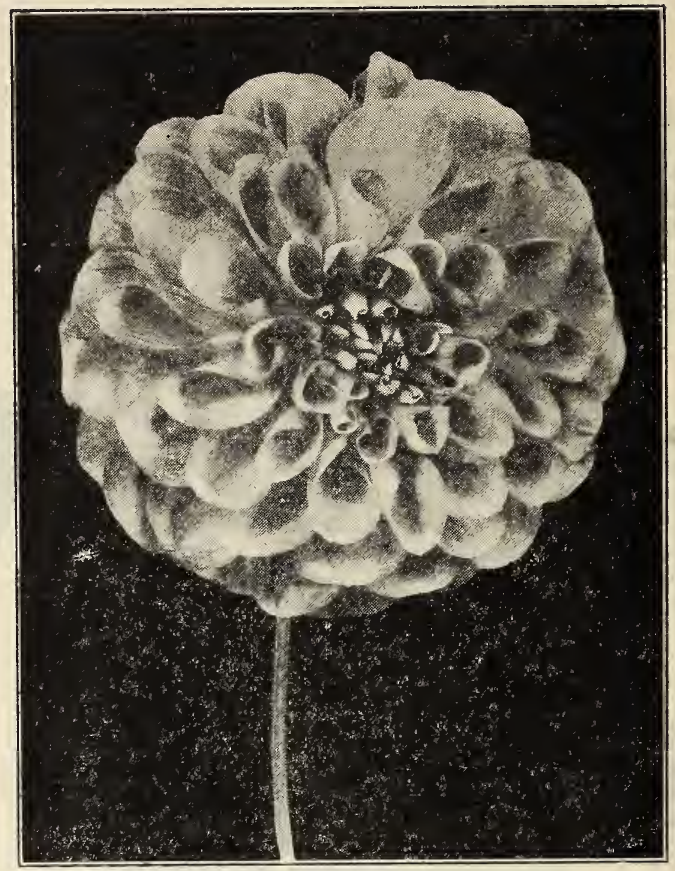

Bronz Kiraty

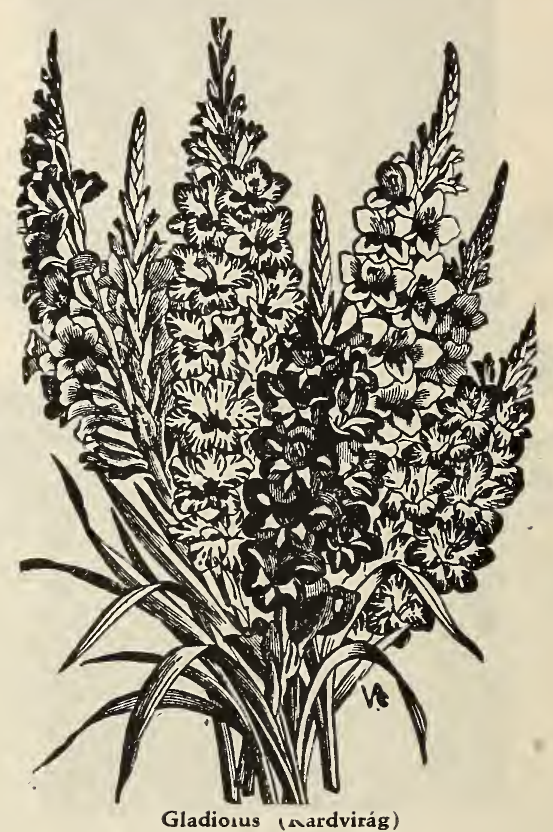

\section{Gladiolus}

GLADIOLUS GANDAVENSIS. Kertek diszi. tésére nagyrabecsült nóvény. Báyss nyári világ, kard alaku levelekkel és sokszinï virágszinekíel. Virág-szinei: remek piros, sárga, fehér, kék, rózsaszinü és tarka. A szinek vegyitve vagy külónkülön kaphatók. 1 darab 15c; 10 darab \$́i.25. 


\section{Tubarózsa}

TENYÉSZTÉSE: Ültessük a hagymákat szabad földbe május elején, egy láb távolságban és ha jó talajba ültetik, már augusztus. ban virágzik. Összel, mielött a fagy beáll, a hagymákat a földböl ki. szedjük és száraz, meleg pincében teleltetjük. Minden tavaszon a fenti utasitás szerint, ismét kiültetjük.

\section{TUBARÓZSA-POLYNTHES} TUBEROSE FL. PL. Február és márciusban cserepekbe, májusban pedig a szabadba ültetjük. Nagy, illatos, gyöngyfehér, teljesen kifej. lett, gyönyörü virágokkal. 1 darab 15 c; 10 darab $\$ 1.25$.

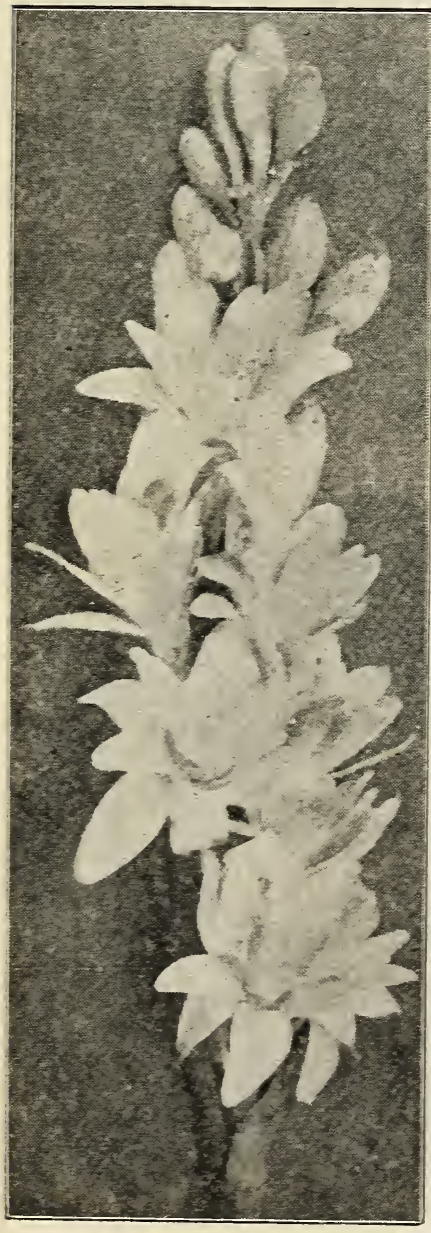

Tubarózsa
TÉLÁLLÓ GUMÓS ÉS VIRÁG NÖVÉNYEK:

Az élő növények a leg. több örömet szolgáló virá. gok a kertben, mert a ta. vasz első ébredésétől fogva mindaddig, mig a tél be nem áll, gyönyörködtetik a virág barátokat a kora tava. szi növésükkel, virágaikkal, levélzetükkel.

LILIUM AURATUM. Felülmulhatatlan szépségü télálló liliom faj. Ezen liliom virágai szépsége és pompázó illata miatt a leg. szebb kerti disznövények kö zé emelkedett. Virágjai nagyra kifejlödnek, melyek gyönyörü viasz fehér és sürüen pettyezve vannak barna-piros szinekkel. A virág szirmok közepén teljesen végig gyönyörü arany. sárga szalag disziti, amely. töl nyerte az Arany Szalag Liliom nevet. 1 darab $45 c$; 10 darab $\$ 4.00$.

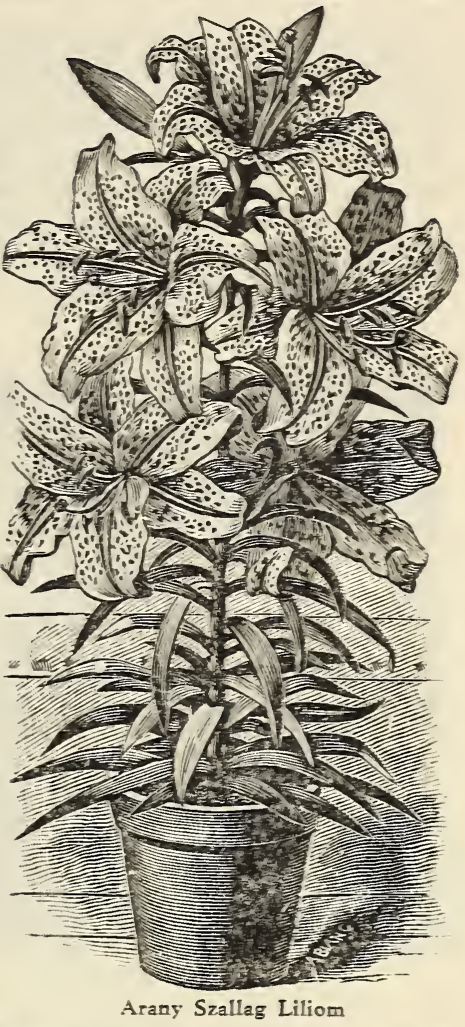

\section{Fehér}

Liliom

LILIOM CAN. DIDUM. - A legszebb fehér kerti. Évekig tartó liliom. 1 darab 35c; 10 darab $\$ 3.00$.

\section{Tigris}

Liliom

LILIUM TI. GRINUM. Narancs-skarlát fe kete foltokkal. 1 darab 40c; 10 darab $\$ 3.00$.

\section{Nap Liliom}

FUNKIA GRANDIFLO. RA. Különösen árnyékban jól növő virágfaj. Kecses alaku fe hér, liliomszerü. virágokkal. 1 darab 20c; 10 darab $\$ 1.75$.

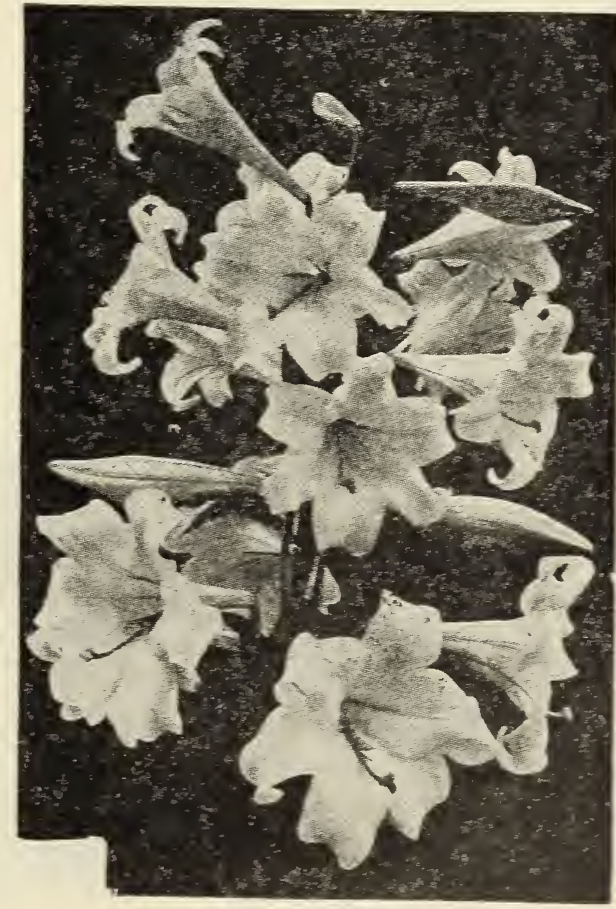

Feher Liliom 
LILIOM REGAL. A legujabb és a legszebb az összes liliom fajok között. Ezen uj faj liliomot Kinából importálták pár éve és oly gyönyörünek vált, hogy a virágkereskedők csak egyedül már ezen fajt használják üvegházaikban husvéti liliomnak. Ezen liliom teljesen télálló, a virágjai viaszfehérek, amelyeknek a közepe kanári sárga. A palánták kifejlődnek 3 láb magasakra és minden egyes szár hoz 7-8 gyönyörü virágot, amelyeknek nagysága 7 col átmérö, illata felülmulhatatlan és ami a legjobb ezen liliomnál, az, hogy nem szükséges ősszel ültetni, hogy tavaszon virágozzon, mint a Fehér Liliomot, hanem csak tavaszon és már azon az éven junius-juliusban teljes virágzásba jön. 1 darab $75 c ; 10$ darab $\$ 6.00$.

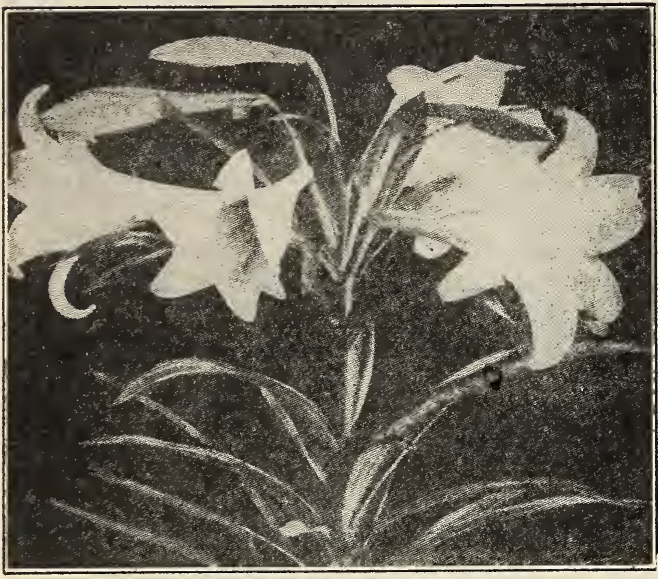

Regal Liliom

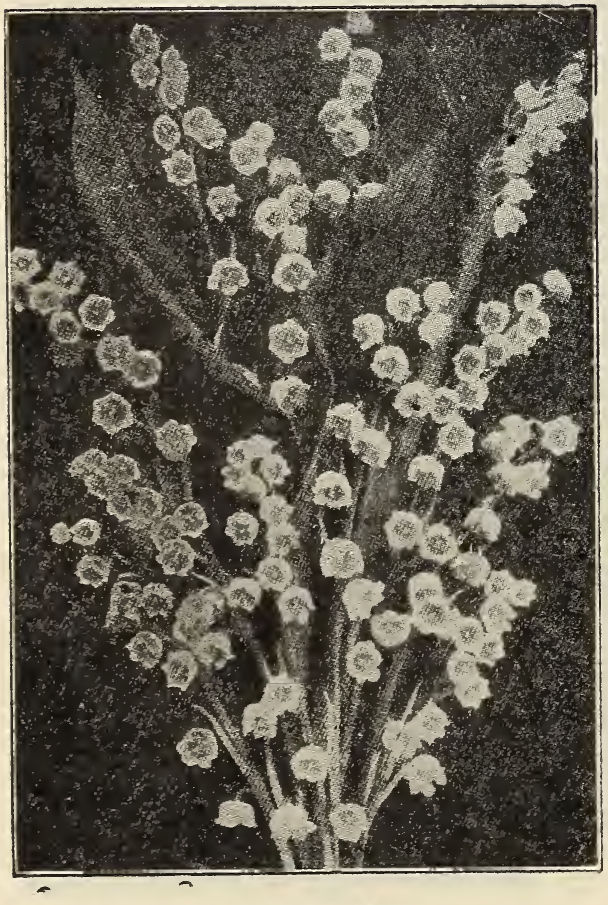

Gyöngyvirág

\section{Gyöngyvirág}

TENYÉSZTÉSE: Ültessük a gyökereket vagy házunk északi tövébe, vagy árnyas fák vagy bok. rok alá, mert a gyöngyvirág egyedül az árnyas helyet szereti.

GYÖNGYVIRÁG. Legelső kedves tavaszi virág, lecsüngö, fehér harangalaku, remek illatu virágokkal. Minden árnyékos helyre gyöngyvirágot kell ültetni. 1 darab 10 cent; 10 darab 60c; 100 darab $\$ 5.00$.

\section{Kék Ibolya}

VIOLA ODORATA. Márciusi ibolya. Ki ne ismerné ezen szerény tavaszi virág illatát? $\mathrm{Az}$ ibolya éveken át maradhat egy helyen és tavasszal el van virágokkal árasztva, amelyek a legkellemesebb illatuak. 1 darab 20c; 10 darab $\$ 1.75$.

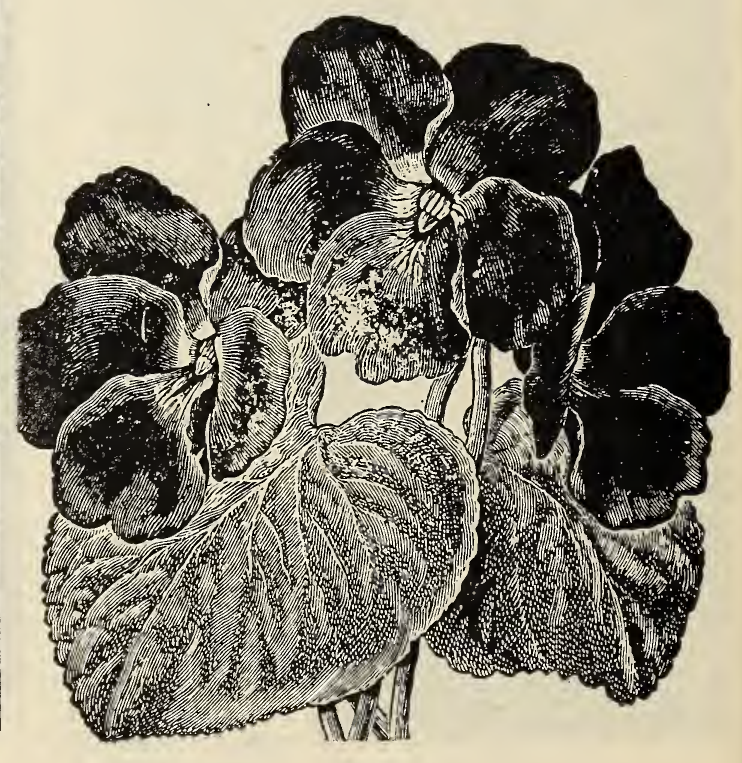

Kèk Ibolya 


\section{Katalin Rózsa vagy Erzsébet Virág}

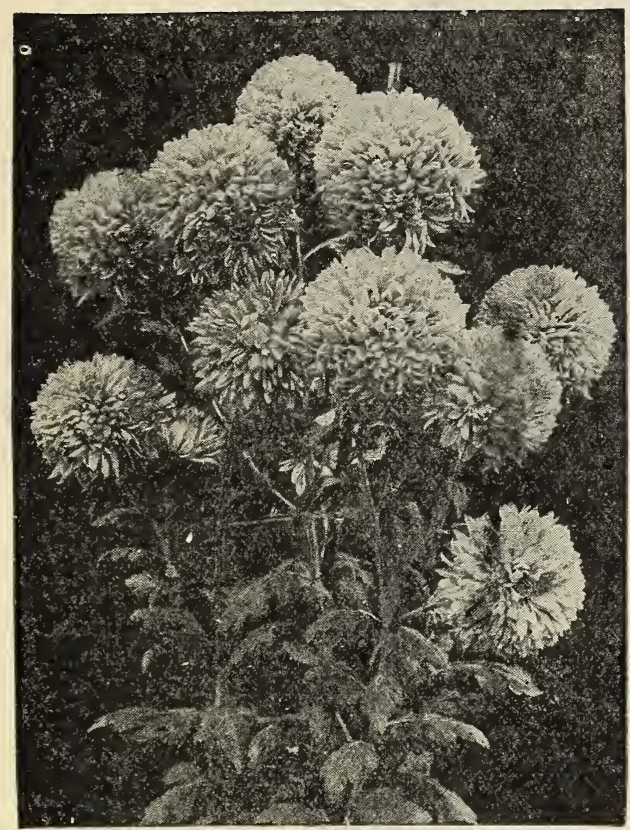

Katalin Rózsa vagy Erzsébet Virág

KATALIN RÓZSA. Mindenki által ismert és bálványozott virágfaj. Remekebbnél remekebb fehér, sárga, piros és rózsaszinü nagy, kellemes illatu virágokkal. Nagyon alkalmas, bárhová ültetjük megnő, ugy napos, mint árnyas helyeken, agyagos, kavicsos vagy homokos földben egyaránt jól tenyészik és október hónapban virágzk. 1 darab 25c; 10 darab $\$ 2.00$.

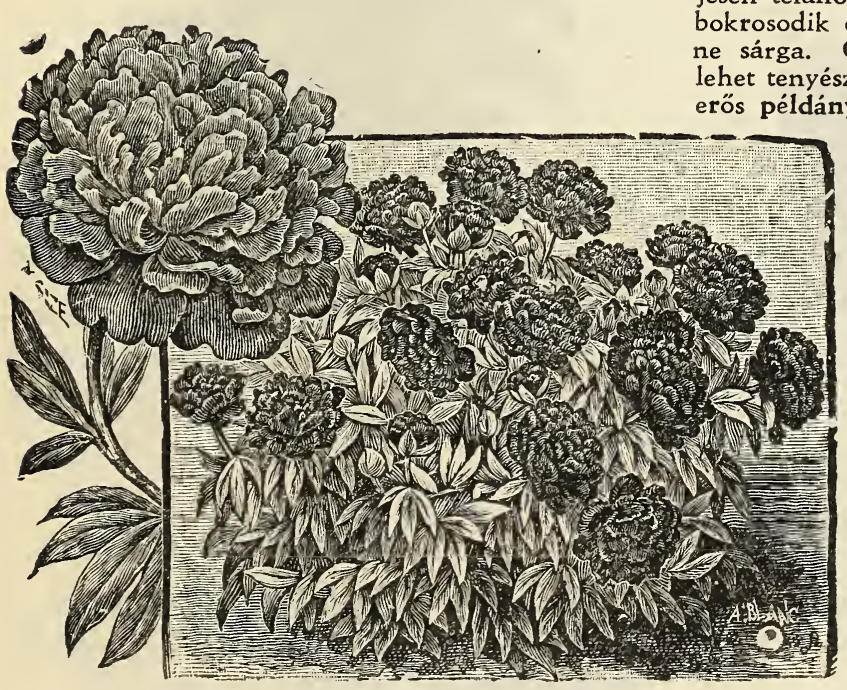

Pünkösdi Rózsa
IRIS KAEMPFEREI. Ezen gyönyörü évelö virág a leggyönyörübb az összes évelő növények között, virágja a legizlésesebb szinekben pompázik. Piros, fehér, kék és rózsaszinekben. 1 darab 35c; 10 darab $\$ 3.00$.

\section{Szallagfü vagy Cifrasás}

PHALARIS LOL. VAR. Mindenki által ismert cifrasás, hosszu, vékony, zöld és fehér-, tarka le. velekkel. Csokrokban virágok mellé kitünöen használható. 1 darab 20c; 10 darab $\$ 1.75$.

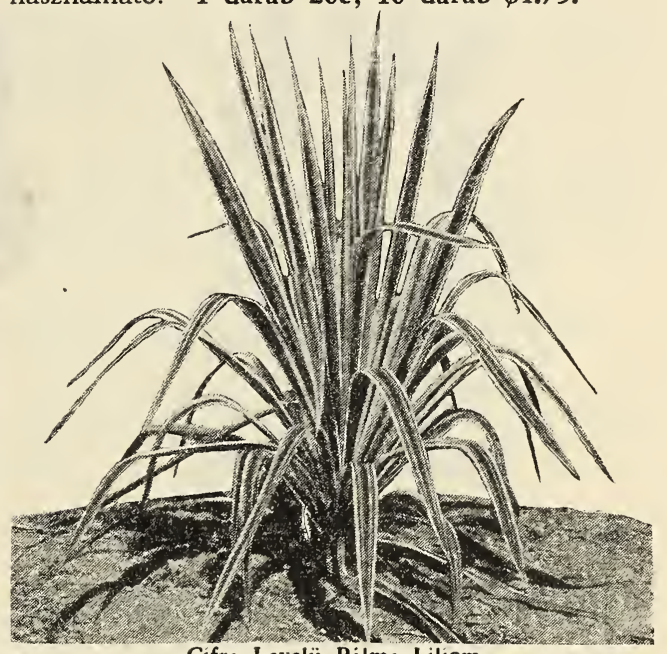

Pálma Liliom, tarka levelii

YUCCA FILAMENTOSA AUREA VARICA. TA. Ezen disznövény válfaja a zöld levelü Pál. ma Liliomnak és annyiban különbözik, hogy ezen fajnak levelei egész világos és zöld vonásos, amely tarkázat hosszában van a leveleken és annyira élénk szin, hogy messze távolról is feltünést kelt szinénél fogva. Kardalaku levelei oly kemények, hogy még télen át is egyenesen fölfelé állnak. Teljesen télálló, lehet pázsitokban ültetni. Idővel elbokrosodik és minden évben virágzik, virágja szine sárga. Cserépben vagy nagyobb edényben is lehet tenyészteni és gyönyörü szoba növény. 1 éves erős példány. 1 darab $75 \mathrm{c} ; 10$ darab $\$ 5.00$

YCCA FILAMENTOSA. Tro. pikus alaku disznövény, nagy, fehér, harang alaku virágokkal. 1 darab 25c. Expresszen 10 darab $\$ 2.25$.

\section{Pünkösdi vagy Bazsarózsa}

PEONIA OFFICINALIS. Ugyan

ki ne ismerné e gyönyörü virágot? Tökéletesen kifejlett példányok. Valóságos csodák. Fehér, piros és rózsaszin diszfajokban. 1 darab 50c. Expresszen 10 darab $\$ 4.50$. 


\section{Phlox vagy Lángvirág}

PHLOX PANICULATA. Kedves és hálás kerti diszvirág. Csekély ápolás mellett oly dusan virágzik, ami igazán bámulat. Kapható a létező legszebb piros, fehér, rózsaszin, stb. szinárnyalatokban. 1 darab $20 \mathrm{c} ; 10$ darab $\$ 1.75$.

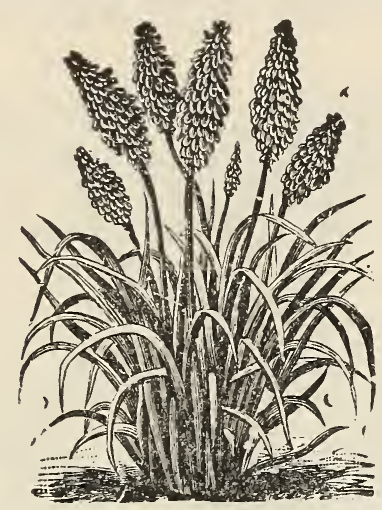

Tritonna

TRITONNA PFITZERI. Pázsitban vagy kertben felülmulhatatlan szép disznövény. Leve. lei a sáshoz hasonlitanak, sötétzöldek. Erősebb hajtásai fáklya alaku, szép piros és narancsszinü virágot hoznak. 1 darab $25 \mathrm{c} ; 10$ darab $\$ 2.00$.

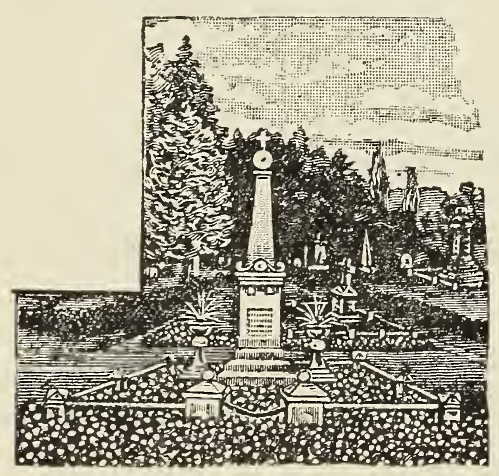

Télizöld Sirra Ültetve

\section{Télizöld}

VINCA MINOR. Magyarországról mindenki által ismert télizöld, amely sirok be. futtatására, továbbá fák alatt, ahol fü nem nő, nagy sikerrel használtatik. Gyönyörü nagy csillagalaku, mély kék virágokkal. 1 darab 20c; 10 darab $\$ 1.75$.

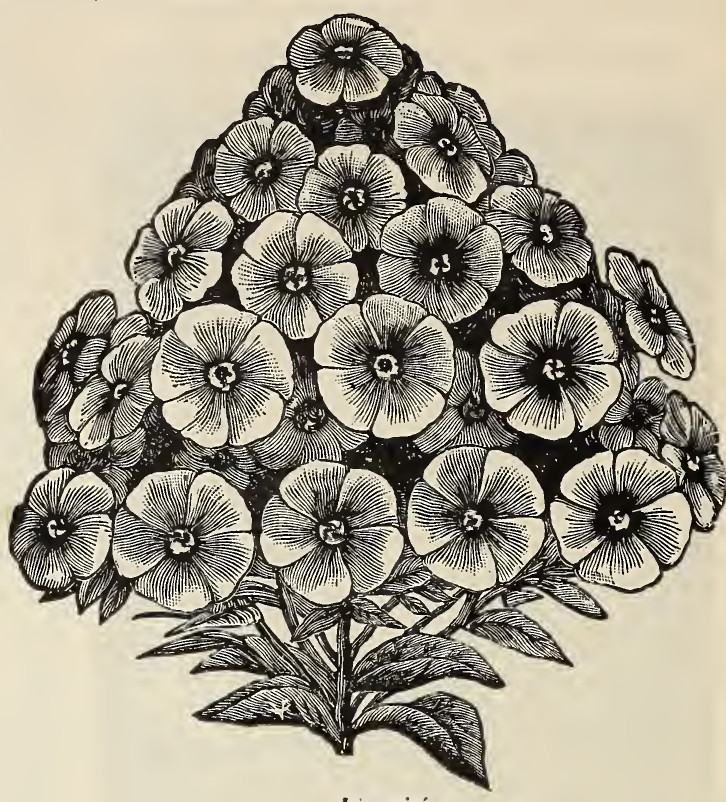

Langvirág

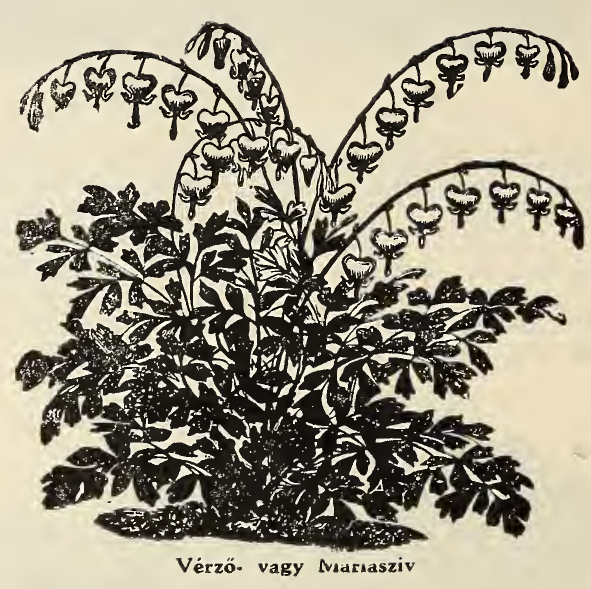

Vérző- vagy Máriasziv

DIELYTRA SPECTABILIS. Legko. rábbi tavaszi növény, apró, kedves rózsaszinü harangocskákkal. 1 darab $50 \mathrm{c} ; 10 \mathrm{da}$ $\mathrm{rab} \$ 4.50$.

\section{Papaver-Évelő pipacs}

PAPAVER ORIENTALE. Csodaszép izzó tüzpiros virágu évelö mák. 1 darab $25 \mathrm{c}$; 10 darab $\$ 2.25$. 


\section{Gyümölcsfák}

Telepünk föágát a gyümölcsfa tenyésztése képezi. Ennek folytán csakis oly gyümölcsfákat nemesitünk és állitunk elő az igen tisztelt vevőink részére, amelyek kiváló jó tulajdonságaiknál fogva már bebizonyultak a legjobbaknak ugy gyors növésükre, mint gyümölcs hozatalukra.

Valamennyi eladásra kerülő gyümölcsfáink három éves faiskolai példányok, dus gyö. kérzettel, szép koronával birnak. A magasságuk átlag $6-8$ láb, ugy, hogy kiültetésük után pár évre - tekintettel a fajnemekre - gyümölcsöznek.

Azon esetben, ha az igen tisztelt vevőink nem ismernék a fajtákat, tessék azokat reánk bizni, csak azt kérjük megjegyezni csupán, hogy nyári, őszi, téli, illetve korai, közép-késői fajok legyenek. Biztositjuk igen tisztelt vevőinket, hogy a küldött fajtákkal meg lesznek elégedve minden tekintetben.

\section{Gyümölcsfák szállitása egyedül csak Expresszen vagy teheráruként eszközöltetik.}

Az ültetés ideje. Gyümölcsfákat, bogyós gyümölcsü csemetéket, szőlöt, diszfákat és bokrokat ültethetünk október elejétől április végéig, kivéve hideg időt, amikor a fa gyökere könnyen elfagy. hat.

Bánásmód a megérkezéskor. Gyümölcsfák, rózsafák, stb. megérkezésük után a csomagból azon. nal kibontandók és állandó helyükre ültetendők. De ha azok bármi oknál fogva nem ültethetők ál. landó helyükre, készitsünk el egy $\mathrm{V}$ alaku árkot (sáncot) és ássuk be őket ideiglenesen, mig az ül. tetéssel készen nem vagyunk.

Megfagyás esetén, azaz ha a csomagolásnál használt moha és a fák gyökerei összefagyva érkeznének meg, - ami nincsen ártalmára a fáknak - helyezzük a csomagot fagymentes helyre, ahol a fagy lassan kienged belolle.

Az ültetés. Frissen felszántott vagy forgatott területen csak akkora gödröt ássunk, amekkora a gyökerek befogadására elegendő. Régi forgatott területeken, vagy igen jó talajokban kissé nagyobb gödröt ássunk.

A fa gyökereit tanácsos ültetés előtt átvizsgálni és a letört darabokat éles késsel eltávolitani. A fát oly mélyre, vagy egy kicsit mélyebbre ültetjük, mint az nálunk a faiskolánkban ültetve volt.

\section{ALMAFÁK - NYÁRI FAJOK.}

Gyümölcsfák, rózsafák, stb. ültetésénél azon legyünk, hogy a gödör elég nagy legyen a gyökerek befogadására és hogy a föld felső része (humus) jusson közvetlen a gyökerekhez és a föld szilárdan oda legyen taposva a gyökereihez.

A metszést végezzük jó éles késsel, nem félve attól, hogy talán a fákat nagyon megcsonkitjuk. A metszés mindig tavaszon végzendő, még az öszön ültetett fákon is.

Ne feledjük el az ültetés után mindennemü fákról, bokrokról, stb. a jelzőtáblákat eltávolitani (levenni), mert ezek rajtahagyása folytán a fák átvágását és egyéb elpusztulást vonnak maguk után.

A fák betrágyázása. Nagyon ajánlatos őszön a gyümölcsfákat, stb. félérett trágyával körülrakni és azt a tavaszon a földbe a fák körül beásni.

\section{Astrakáni Piros Alma}

ASZTRAKÁNI PIROS. A legkorábbi nyári almafaj. Roppant gyors növésü. Gyümölcse középnagy, remek, fényes, skarlátvörös szinü, kellemes, kissé borizü, lédus izzel. 1 darab 80c; 10 darab $\$ 7.50$.
CSERESZNYE ALMA. Jókora nagy, piros szivalaku, cseresznyéhez hasonló faj. Ugy befözésre, mint alma-iz készitésére nagyon kapós. 1 darab 80c; 10 darab $\$ 7.50$.

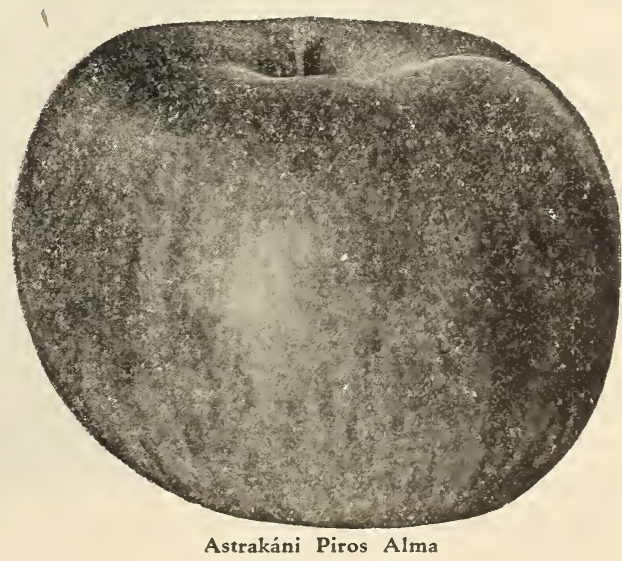




\section{Édes Nyári Alma}

ÉDES NYÁRI. Gyorsnövésü és böter. mő korai alma, nagy, sárga szinü, igen édes, lédus gyümölcsökkel. 1 darab 80c; 10 darab $\$ 7.50$.

b) ŐsZI FAJOK GRAVENSTEINI Nagyon fiatalon termö és erős növésü almafaj. Sárga szinū nagy almákkal, amelyek pi. rossal sávozottak. Remek kora őszi alma, kitünő lédus, savanyu hus sal. 1 darab $80 \mathrm{c}$; 10 darab $\$ 7.50$.

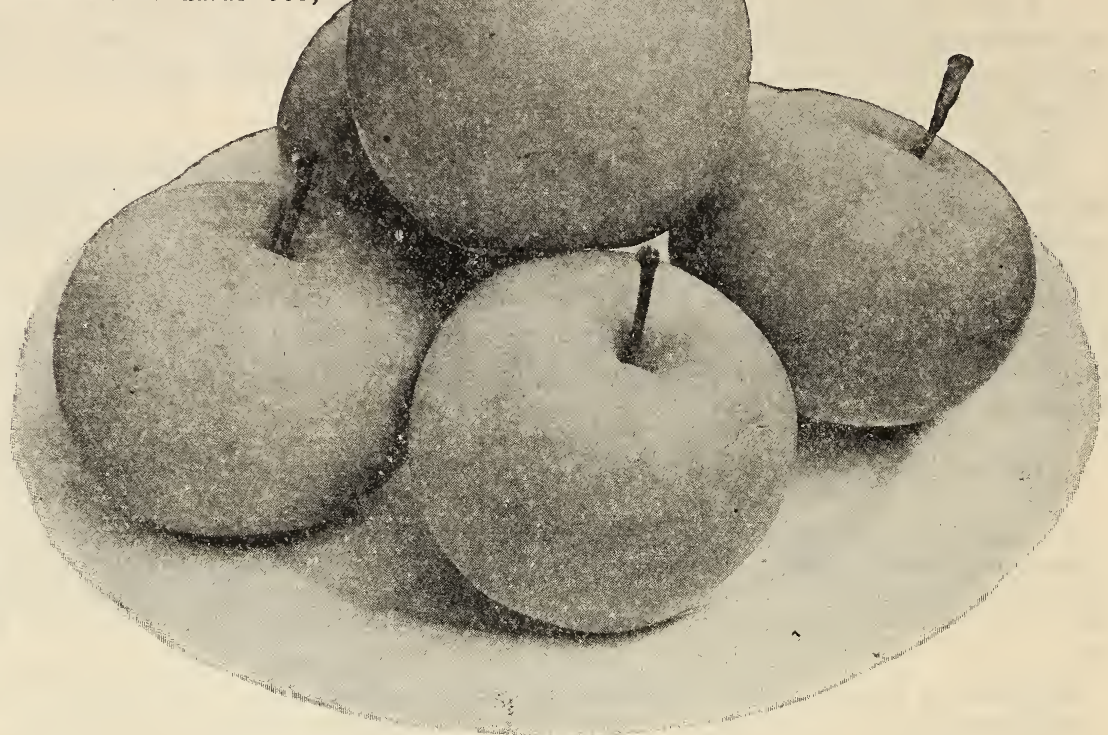

Korai Aratási Alma

KORAI ARATÁSI. Meglehetős nagyságu, hal ványsárga gyümölcsü, nagyon korai nyári almafaj, remek savanykás izzel. Ez a faj kimaradhatatlan a gyümölcsösből. 1 darab $80 \mathrm{c} ; 10$ da$\mathrm{rab} \$ 7.50$.

NYUGAT SZÉPE. Igen nagyra növő, halványsárga gyümölcsökkel, amelyek világos piros foltokkal vannak tarkázva. Husa finom, gyenge savanyu, lédus és olvadós. Kitünő őszi faj. 1 darab $80 \mathrm{c} ; 10$ darab $\$ 7.50$.

\section{OLDENBURGI HERCEGNÖ}

ALMA. Ezen alma ujdonságot Magyarországból hozattuk. -Gyümölcse teljesen gömbölyữ, óriási nagyokká fejlödnek, szine vörös, sárga csikokkal. Érési ideje október és márciusig is el lehet tartani. Értékét a leg. jobban az emeli, hogy 4-5 éves korában már bőven terem. 3 éves szép példányok. 1 da. tab $\$ 1.00,10$ darab $\$ 9.00$.
ÖSZI BORIZÜ. Gyönyörü és nagyon értékes korai faj. Gyümölcse nagy, gömbölyü, piros és sárga csikokkal. Husa finom, gyenge, lédus és kellemes borizü. Kitünő alma fözésre. 1 darab $80 \mathrm{c} ; 10$ darab $\$ 7.50$.

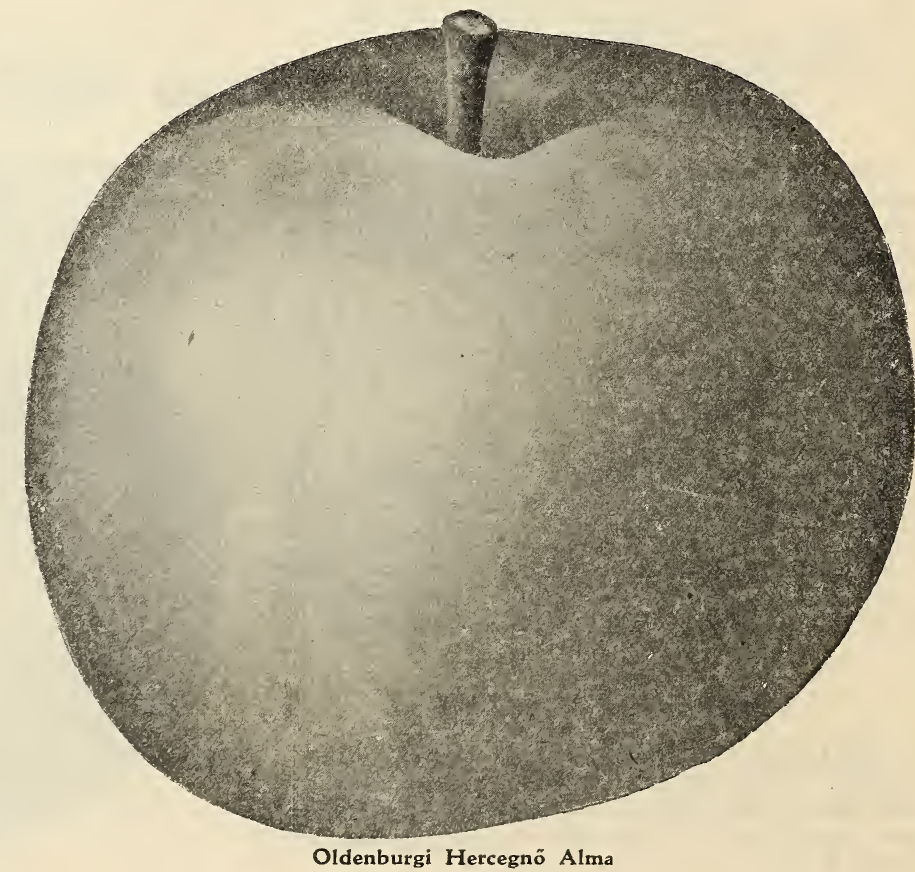


c) Téli Fajok.

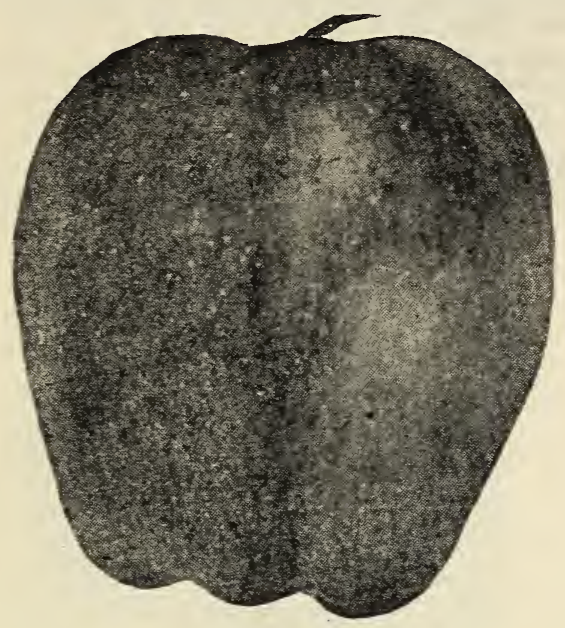

Delicious Alma.

BALDWIN. Roppant nagy hozamu, bõtermó és rendkivü! gyorsan növõ almafaj. Nagy, gömbölyü, remek piros szinü gyūmölesökkel, amelyek a legjobb borizüek és lédusak. Ki. tünõ market faj. A tavaszig eltarthat a gyümölese. 1 darab $80 c ; 10$ darab $\$ 7.50$.

DELICIOUS. Nagyon kedvelt almafaj. Ugy piaci, mint házi használatra az elsö helyet foglalja el. Nincs az az almafaj, amely oly hamar elterjedt volna az ültetök közt, mint ezen faj. Gyümölesei óriási nagyok, brilliant vörös csikokkal. $5-7$ láb magas. 1 darab 80c; 10 darab $\$ 7.50$.

TÉLI BORIZÜ. Remek izü, vörös és sárga sávozott, bor. izü téli alma. Felülmulhatatlan ugy a gyümölcsök szinére va. ló tekintettel, mint kitünö izükre. 1 darab 80c; 10 darab $\$ 7.50$.

JONATHÁN. A lètezó almafäk között a legelsõ helyet foglalja el, nagy szalmasairga és pirossal majdnem egészen be mosott gyümölcsökkel. Koràn, rendesen és böven terem. 1 darab 80c; 10 darab $\$ 7.50$.

TÉLI ARANY PARAMÉN. Érik október végétõl, de rend. szerint november és januàrban a legèlvezhetöbb. Remek zöl. dessárga szinü és kıtünö izü gyümölesökkel. 1 darab $80 \mathrm{c}$; 10 darab $\$ 7.50$.

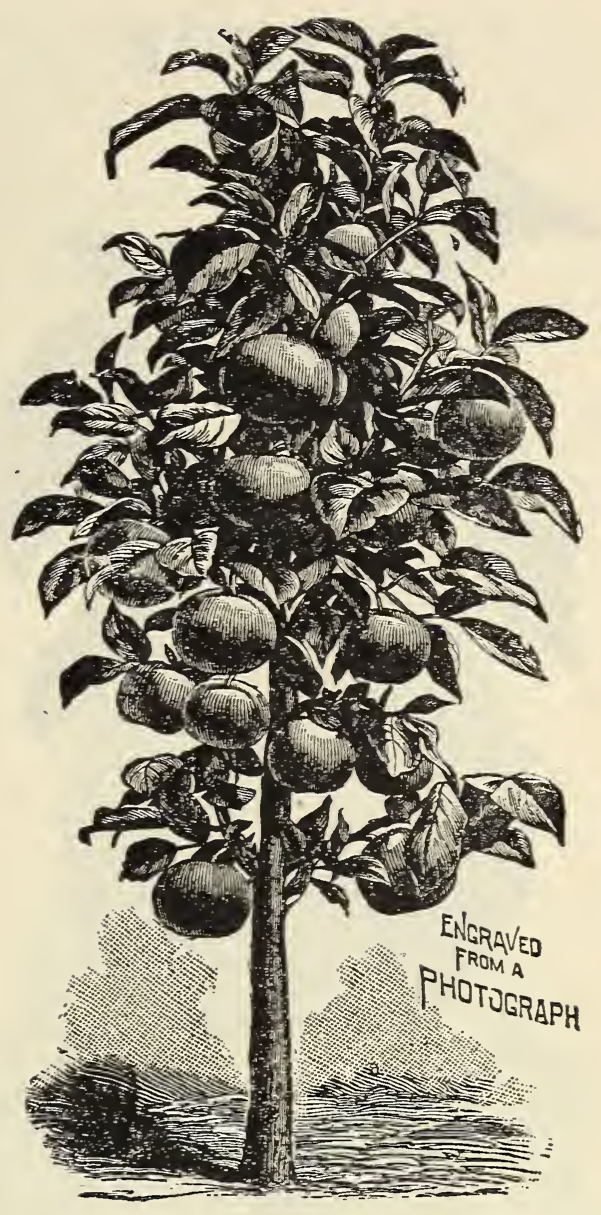

Fiatal Baldwin Almafa Termésben.

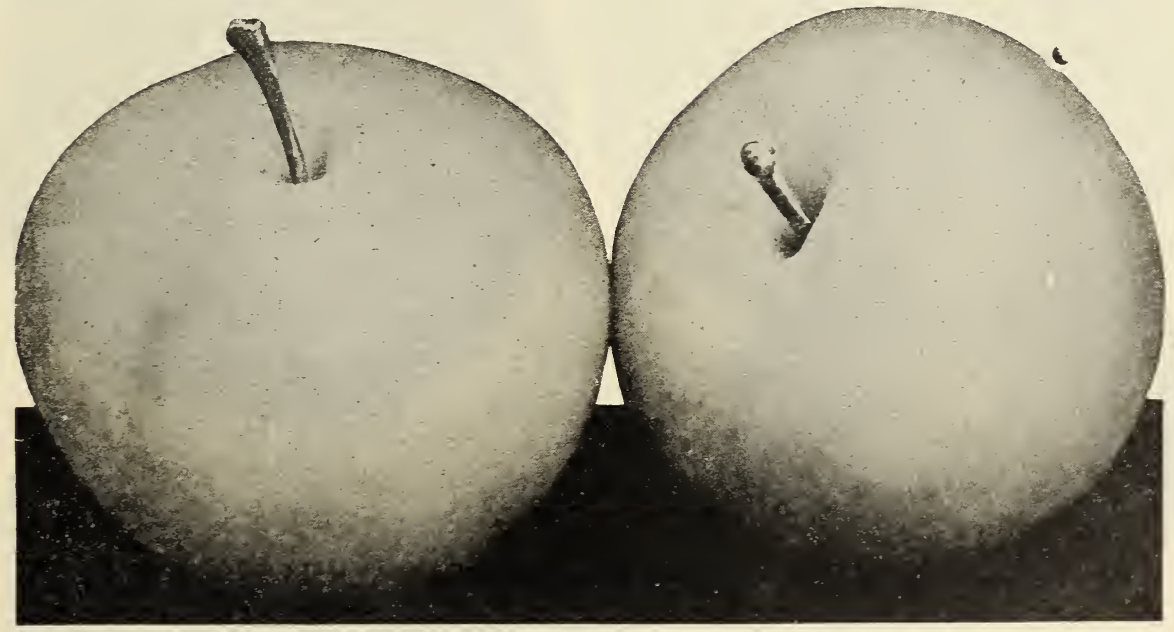

Téli Arany Paramén Alma. 


\section{KÖRTEFÁK} NYÁRI FAJOK.

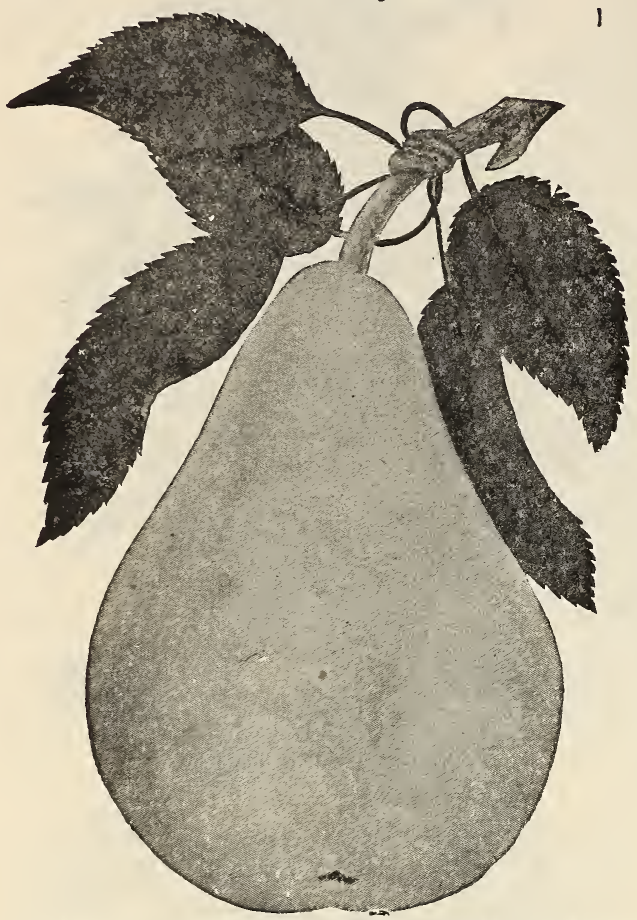

BARLETT VAJKÖRTE. Nagy, viaszsárga, vörös árny nyal bevont, olvadós és remek édes, lédus gyümölcsü nyári körte. Nagyon korán termö és gyorsan növö nyári faj. Érése augusztus hó. 1 darab $\$ 1.10 ; 10$ darab $\$ 10.00$.

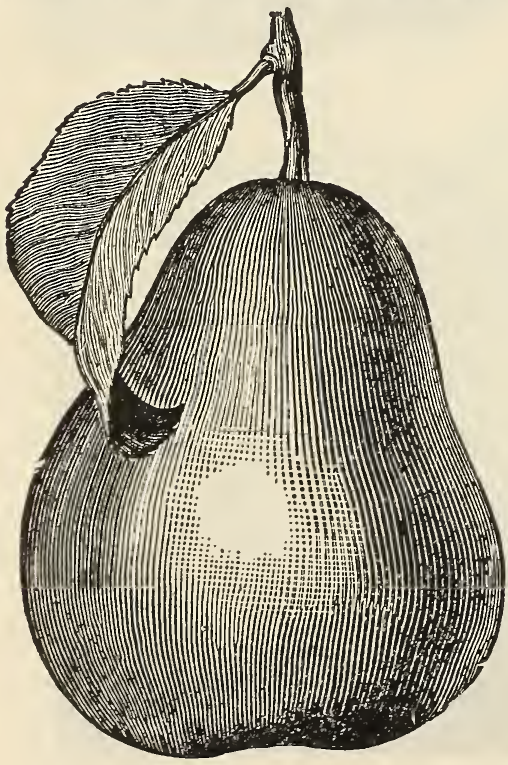

Korai Aratási
KORAI ARATÁSI. Középnagy gyümölcsü ès kitünö minöségü körte faj. Gyümölcse féloldala sárga, a napos oldala piros, husa édes és olvadós. 1 darab \$1.00; 10 darab \$9.00.

CLAPP KEDVENCE. Remek nyári vajkörte, a nap felöli oldalán rózsaszin pettyekkel. Tanácsos érése elött 8 10 nappal leszedni a fáról. 1 darab $\$ 1.00 ; 10$ darab $\$ 9.00$.

KONC VAJONCA. Általánosan ismert korai faj. Nagy, hosszukás, finom édes izü, félig sárga, félig piros gyümöl. csökkel. 1 darab $\$ 1.00 ; 10$ darab $\$ 9.00$.

\section{b) ÖSZI ÉS TÉLI FAJOK}

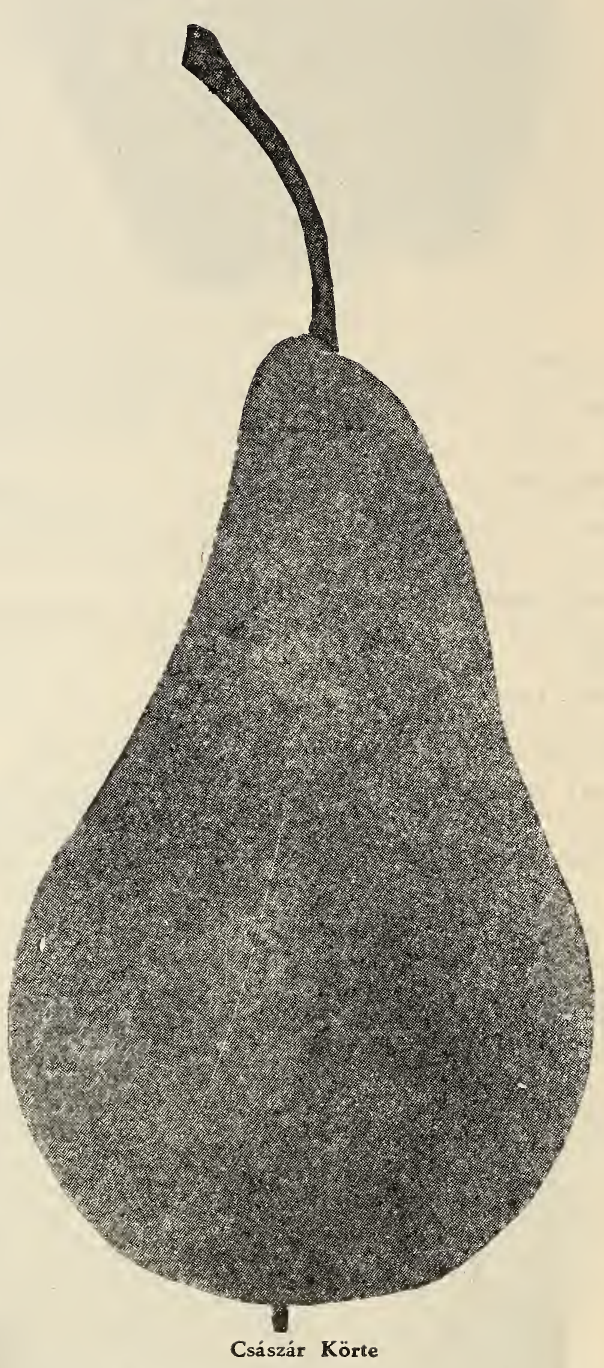

CSÁSZÁR KÖRTE. Nem ujdonság, de bő termõségénél, óriasi nagyságánál, gyönyörü szine, alakja és fenséges izénél ofgva a legismertebb és legelterjedtebb egész Magyarországon. Annyiból is legismertebb, mert minden év. ben bö termést ad és ennélfogva, alıol csak hely van egy fának, oda császár körtét ültetnek. Gyümölcse szép alaku, óriási nagyra fejlödik, szine északi oldalán sárga, déli oldalán pedig halvány piros. Érési ideje szeptember hónap $5-7$ láb magasak. 1 darab $\$ 1.10$; 10 darab $\$ 10.00$. 


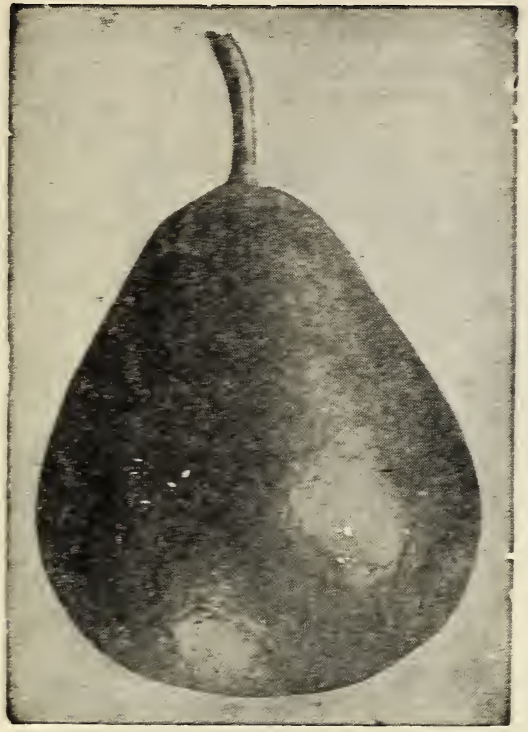

Székely Mrgonca.

SZÉKELY MAGONCA. A o gyümöi su, mézédes, nagyon bốven termö körte faj. Gyimölcsének egyik oldala sárga, a másik pedirg piros. Karácsonyig altartható. Ézen jó fas rulaidonsága méz az is, hogy atultetése utin 2-3 évre már hozza a gyümöçöt. 5-7 láb magas. 1 darab $\$ 1.10 ; 10$ darao $\$ 10.00$.

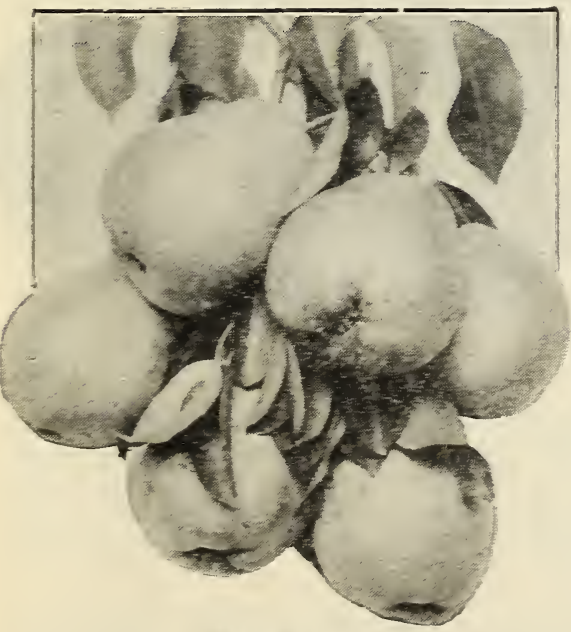

Flemish Szépe.

FLEMISH SZÉPE. Remek 1zi, korai sિzi körte faj. Nast, zōldessárga ziümölcsei fi noz édesek és léd isak. Általénosan minden érben tồen terem. 1 darab $\$ 1.10 ; 10$ darab $\$ 10.00$.
LÕRINC VAJKÖRTE. Husrétig is elalló téli vai. körte. Nagy, szintén aranysárga szinu grümölesei felsézes izüek. Igen bõ és általánosen minden érben sokat termő faj. 1 darab $\$ 1.00 ; 10$ darab $\$ 9.00$.

NEMES KEIFFER. Nagy, aranysárga gyümölcsü és kirünö minöségū, nagyon sokáig eltartó téli faj. Kitünö üvegbeni eltevésre, keménysége miart ia s.on keresett market faj. 1 darab $51.00 ; 10$ darab $\$ 9.00$.

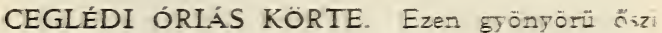
körte gyümölcs nagysága bámulatba ejuerte az egésc közönséget. A gyümölos sulya 1 font és 5 ounce volt. Szine szedéskor világos, késôbb pedig már sár ga, ize fenséges, érik októberben és hónapokig eltart ható. 1 darab $\$ 1.10 ; 10$ darab $\$ 10.00$.

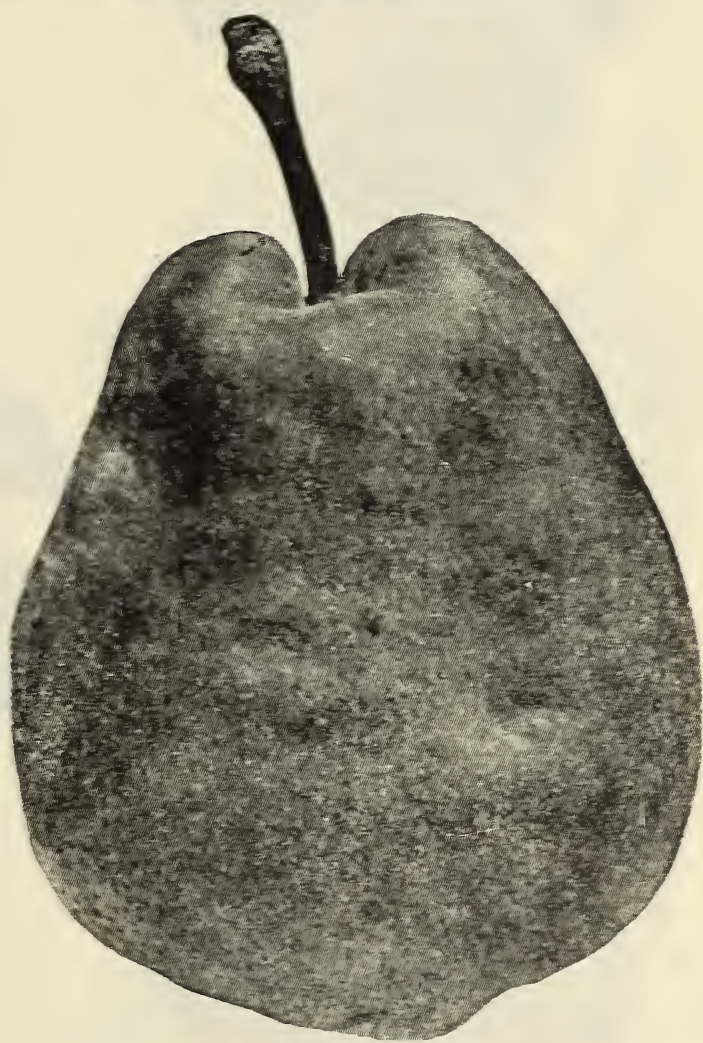

Hercesaó Vajkorte.

HERCEGNOO VAJKÖRTE. A legioboan elterjed: és rermelt igazi vajkōrte. Óriási nagyságu sárga zyü. mölcsei felsézes, édes izüek. Kotán és roppant böven rerem a fája. N゙agson ajánljuk ugy házi kerrekbeni ületésze, mint nagyobb mennyiségben piaci te:melésre. Étés: okróber elejétôl norember végéig 1 darab $\$ 1.10 ; 10$ darab $\$ 10.00$. 


\section{CSERESZNYEFÁK}

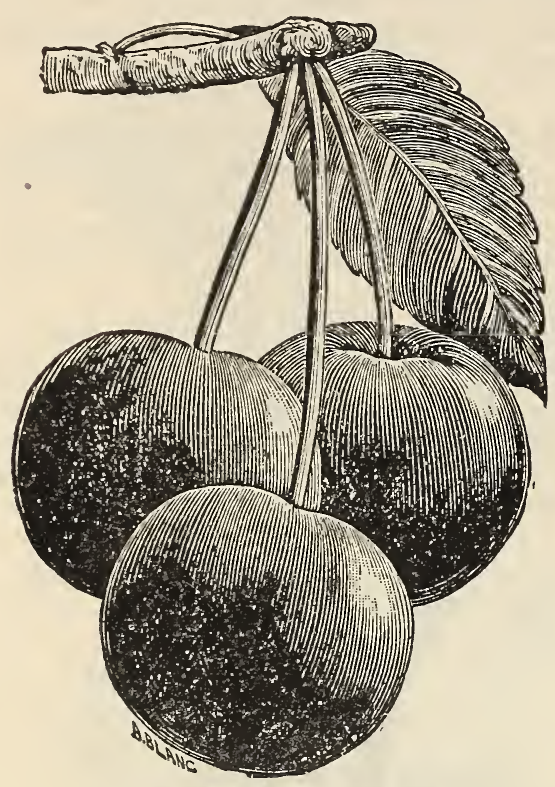

Fekete Ropogós Cseresznye

NAGY FEKETE ROPOGÓS. Juniusban érö szivalaku és nagyon édes izü cseresznye. Kitünő befőttet szolgáltat. 1 darab $\$ 1.10 ; 10$ darab $\$ 10.00$.

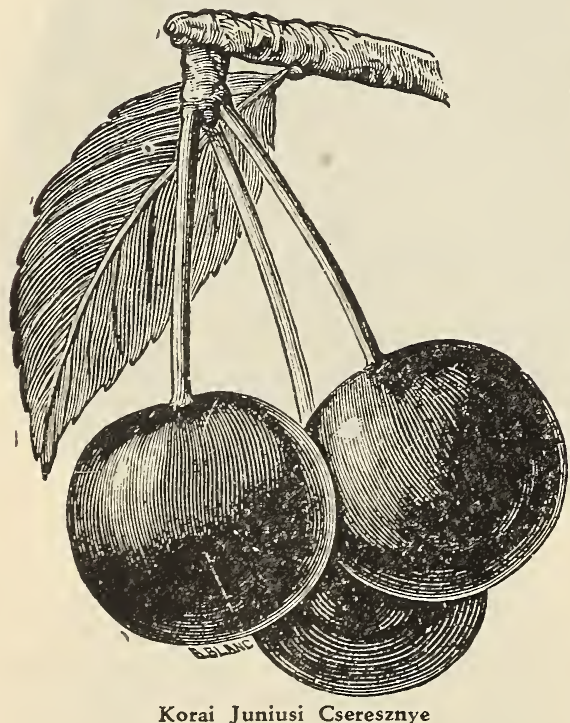

KORAI JUNIUSI. Nagy, világos piros és kellemes izü édes cseresznye. Nagyon bőtermő és korán gyümölcsöző faj. Kitünő házi használatra. 1 darab $\$ 1.10 ; 10$ darab $\$ 10.00$.
NAGY SÁRGA ROPOGÓS. Igen korai, vilá. gos sárga, a másik oldalán pirossal sávozott, kitü. nő édes izü cseresznye faj. Érése junius hónap. ban. 1 darab $\$ 1.10 ; 10$ darab $\$ 10.00$.

LAMBERT KÉSÓI ROPOGóS. A legnagyobb. ra megnövő, szivalaku késői cseresznye faj. Gyümölcse sötétvörös szinü, mikor teljesen megérett. 1 darab $\$ 1.10 ; 10$ darab $\$ 10.00$.

WINDSOR. A legkitünőbb kései sötétvörös ropogós cseresznye, az összes cseresznye fajok kö. zött. Husa nagyon kemény és ropogós és óriási bőtermő ugy házi használatra befőzésekre, mint piaci termelésre elsőrendü. 1 darab $\$ 1.10 ; 10$ darab $\$ 10.00$.

\section{MEGGYFÁK}

KORAI RICHMOND. Egyike a legkorábbi juniusi meggy fajoknak. Bőtermősége felülmulha. tatlan. Fája nagyon korán terem. Gyümölcse kitünő izü, a szine érett alakjában sötétvörös. 1 darab $\$ 1.00 ; 10$ darab $\$ 9.00$.

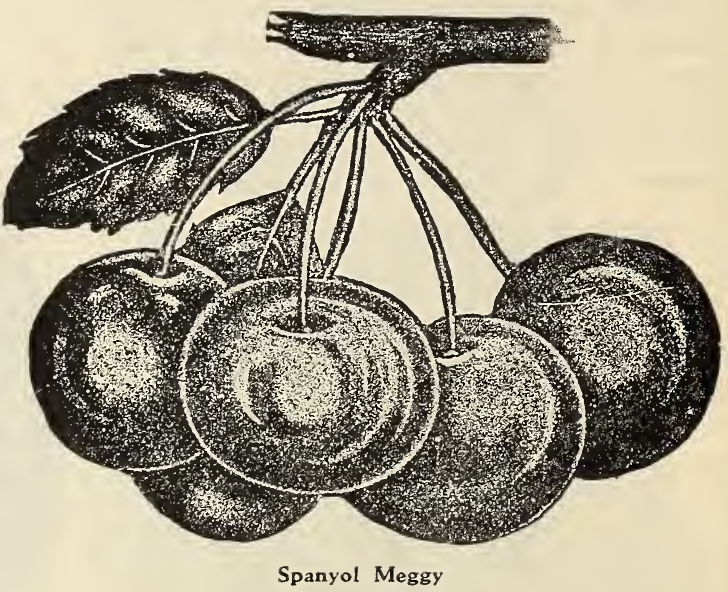

SPANYOL MEGGY. Más néven Tükör Meggy, vagy Oltott Meggy néven is szerepel. Gyümölcse igen nagy, fénylö sötétvörös és keményes. Befốzésre a legjobb meggy fajta. Érése: julius. A legkitünőbb háztartási és piaci gyümölcs. 1 da$\mathrm{rab} \$ 1.00 ; 10$ darab $\$ 9.00$.

HORTENSIA KIRÁLYNÖ. Későn érö remek világos szinü gyümölcsü meggy faj. Gyorsan növő és bőtermő fával. 1 darab $\$ 1.00 ; 10$ darab $\$ 9.00$.

KÉSÖI HERCEG. Késői elsőrendü csemege meggy faj. Nagyon bőtermő és szép egyenes növésü fával. 1 darab $\$ 1.00 ; 10$ darab $\$ 9.00$. 


\section{SZILVAFÁK}

\section{a) Európai Fajok}

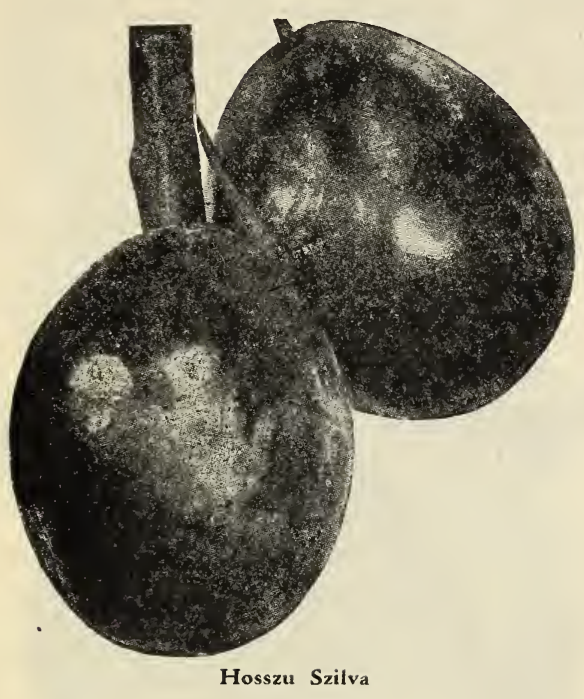

HOSSZU SZILVA. Vagy amint más néven "Házi Szilva," "Aszaló Szilva," "Berzencei," "Magyar Szilva," "Besztercei" elnevezések alatt ismerünk. A legjobban bevált szilva fajok egyike. Alakja hosszu tojásdad, feketés-kék szinnel. Háztartási célokra a legelsőbbrendü. Magbaváló gyümölcsei felséges izüek. 1 darab $\$ 1.10 ; 10$ darab $\$ 10.00$.

KORAI KÉK RINGLó. A legkorábbi violakék szinü szilvafaj, finom izü, édes, lédus hussal. Nagyon bőtermő market faj. Érése: augusztus hóban. 1 darab $90 \mathrm{c} ; 10$ darab $\$ 8.00$.

LOMBÁRD RINGLÓJA. Középnagy, sötétvörös szinü ringló, remek sárga és kitünő izü hussal. A legelterjedtebb szilva faj nagybani eladásra, kitünő házi használatra is, u. m.: befözésre, stb. Bőven terem minden évben. Fája gyorsan növő. Érése: augusztus hóban. 1 darab 90c; 10 darab $\$ 8.00$.

\section{b) Japán Fajok}

JAPÁN VÉRPIROS SZILVA. Óriási nagyságra megnövő gyümölcsökkel, amelyeknek külső szine gazdag élénk piros, a husa pedig felséges édes izü. Nagyon bőtermő és gyorsan növő fával. A gyümölcse ezen fajnak nem sokkal kisebb, mint a közönséges barack. 1 darab $90 c ; 10$ darab $\$ 8.00$.
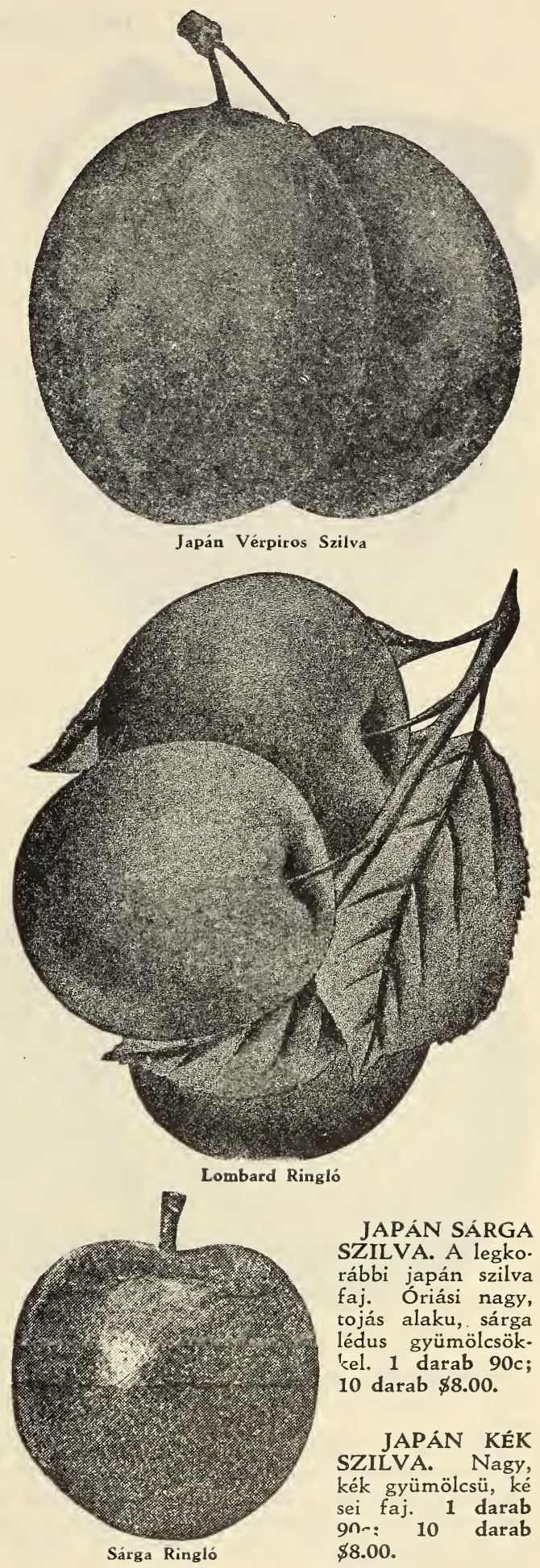

JAPÁN SÁRGA SZILVA. A legko. rábbi japán szilva faj. Óriási nagy, tojás alaku, sárga lédus gyümölcsök'cel. 1 darab 90c; 10 darab $\$ 8.00$.

JAPÁN KÉK SZILVA. Nagy, kék gyümölcsü, ké sei faj. 1 darab 9n-: 10 darab $\$ 8.00$. 


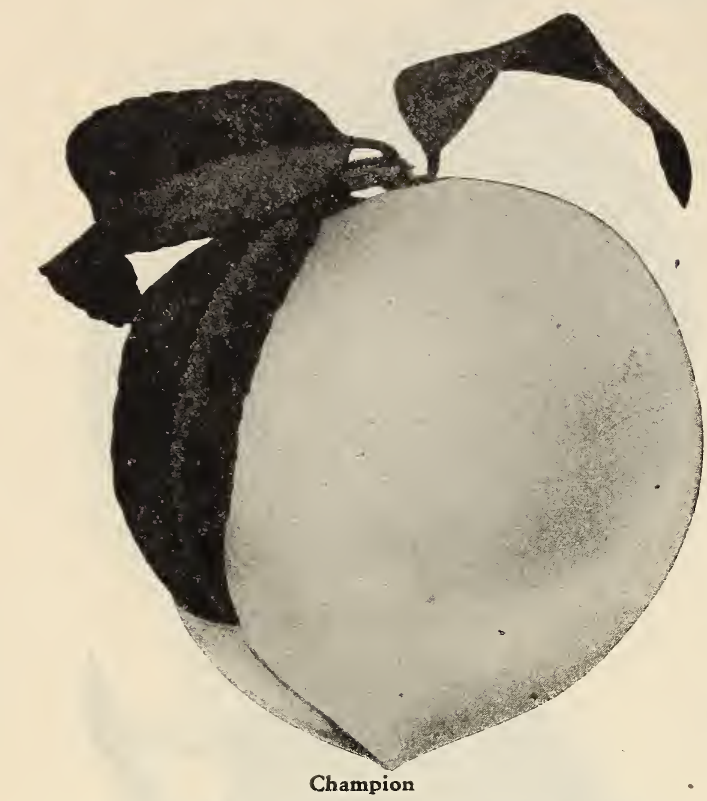

CHAMPION. Óriàs nagyra nơvó faj. Hïja világos piros, husa bel ii fehér, kitïnő izü. Piac : 1 a legmagasabb ára van. Érik augusztus hónap. ban. 1 darab $50 \mathrm{c} ; 10$ darab $\$ 4.00$.

SZENT JÁNOSI. Középnagy sảrga szinü. Gyümölcse lédus és magbaváló. Érese julius. 1 darab 50c; 10 darab \$4.00.

KÉSÖI CRAWFORD. Nagyra növő, rerı.' szinü őszi barack. Roppant bőtermő késői faj. Érése szeptember hónspban. 1 darab 50c; 10 darab \$4.no.

ELBERTA. A leşelsörendü közcpkorai magbaváló market faj. Megnő és bőven terem bármely földön. Érese augusz:ls és szep+em ber hónapokban. 1 darab $50 \mathrm{c} ; 10$ darab $\$ 4.00$.

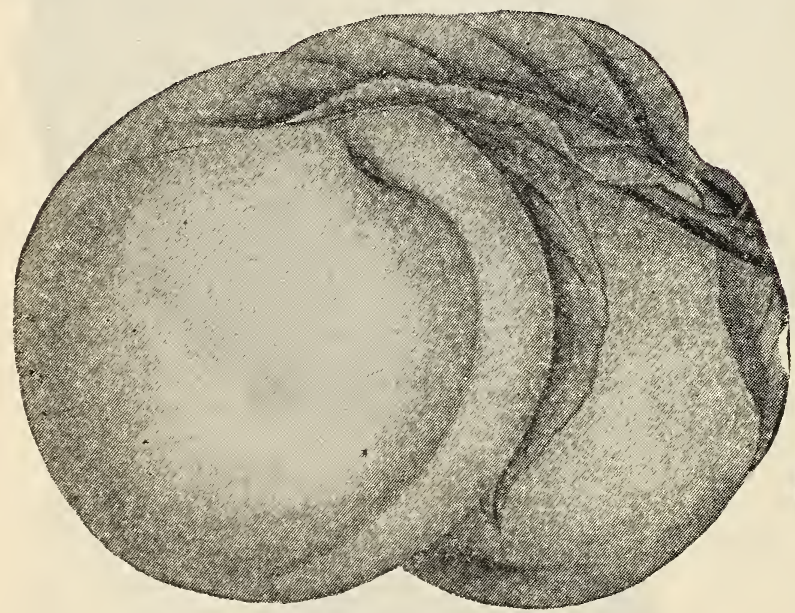

Stearn-féle Késői

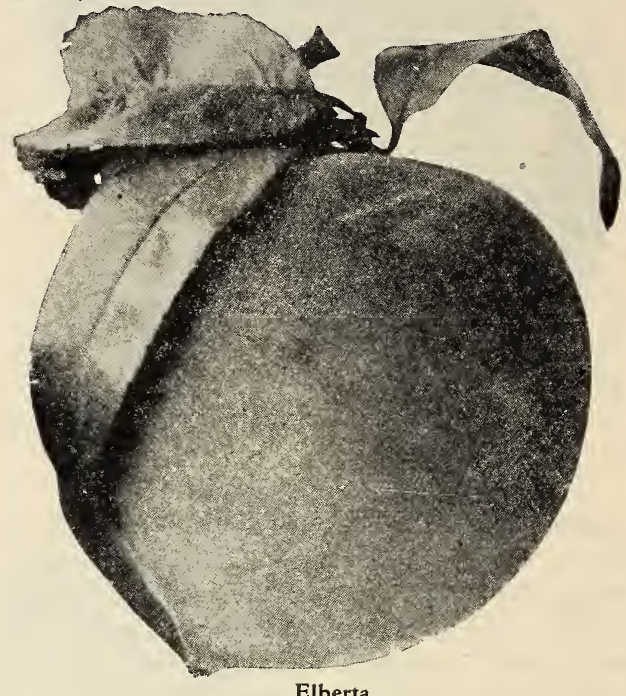

HALE. Ujdonság! Nem lér `z،: olyan barack, amely oly gyorsan elterjedt volna a termelök között, min. ezen faj. Nagysága egv és félszer a! kora, mint az ismert Liberta. Érik öt nappal előbb. Szirie aranysárga, husa szinté világos-sárga és fenséges izü. 1 daı ab 50c; 10 Jarab \$4.00.

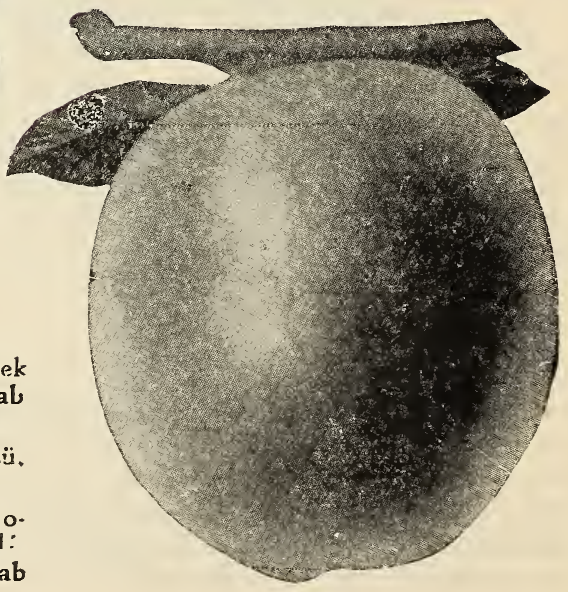

Hale 


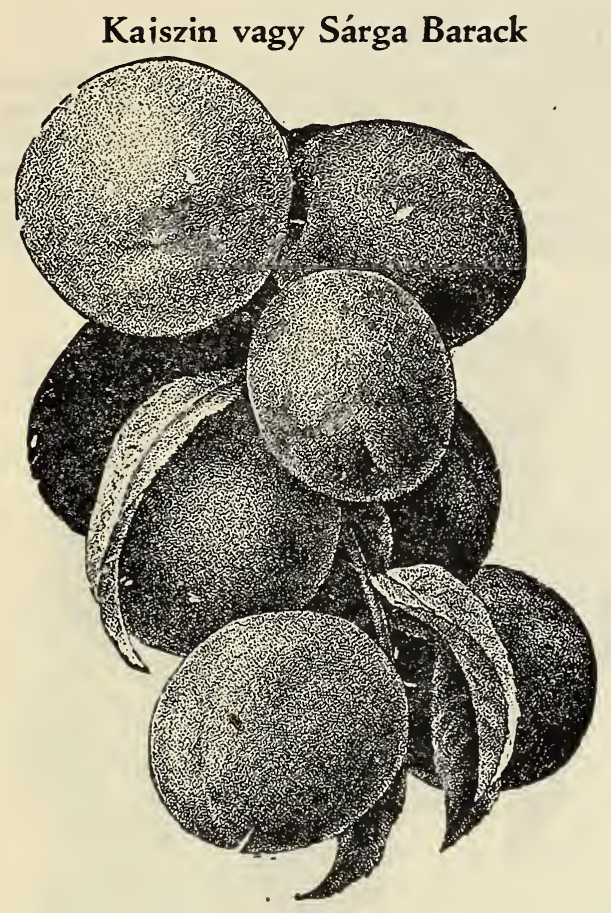

Korai Sándor Barack

KORAI BIBORKAJSZIN. Korán érő nagy, narancssárga, napos oldalon biborvörössel szinezett. Igen lédus és finom za. matu. 1 darab $80 \mathrm{c} ; 10$ darab $\$ 7.50$.

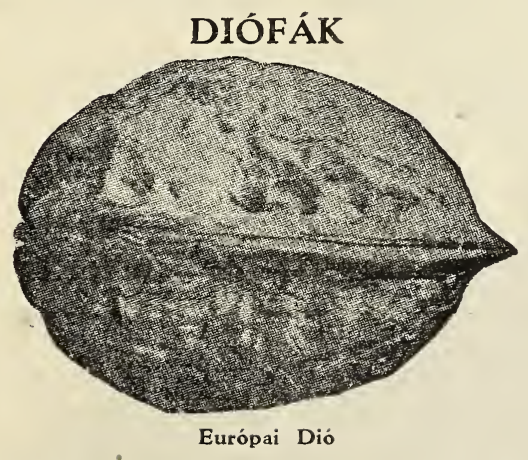

EURÓPAI DIÓ. Valódi európai vékony héju faj. Mi ezen fajt Magyarországból ho zattuk és az itteni gyökerébe van nemesitve, ennélfogva teljesen birja a telet. Rövid 5-6 év alatt óriási fává fejlődnek és termést hoz. nak. 4-5 láb magas, gyönyörü példányok. 1 darab $\$ 1.50 ; 10$ darab $\$ 14.00$.

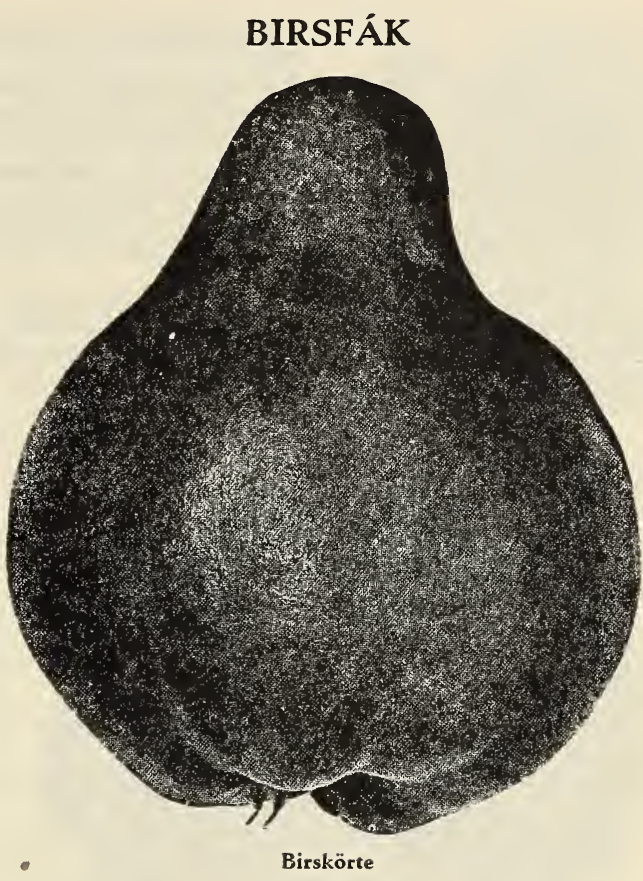

BIRSALMA. Gyümölcse középnagy, alma alaku. Szine zöldessárga, kitünő zamattal. 1 darab $\$ 1.00 ; 10$ darab $\$ 9.00$.

CHAMPION. Nagyon bőtermő és nagy gyümölcsü birs körte faj. Gyümölcsei narancs-sárgák és kitünő izüek, házi használatra is legkitünőbb. 1 darab $\$ 1.00 ; 10$ darab $\$ 9.00$.

ÓRIÁSI BIRSKÖRTE. Óriási gyümölcsü, narancssárga szinü birskörte faj. Rend. kivül böven termö a fája. 1 darab $\$ 1.00$; 10 darab $\$ 9.00$.

\section{ÉDES GESZTENYEFA}

AMERIKAI. Amerikai édes gesztenyefa. Nagy hasznot hozó fa a gyümölcse által. $\mathrm{Ha}$ van a földeinken olyan hely, ami másra al. kalmatlan, ültessünk rá gesztenyefát; ültessünk különösen legelökre. Mint szerszámfa is nagyban keresett. 1 darab $\$ 1.00 ; 10$ da. rab $\$ 9.00$.

JAPÁNI. Japán gesztenyefa. Nagy, édes gesztenyékkel. Nagyon hamar gyü. mölcsöző faj, amelyböl sok pénzt lehet elö. állitani. 1 darab $\$ 1.25 ; 10$ darab $\$ 10.00$. 


\section{BOGYÓGYÜMÖLCSÜ CSEMETÉK.}

A bogyós gyümölcsü csemeték nevelése a házunk körül és a termés épp oly hasznot és élvezetet hozó, mint a nazyobb gyümölcsfáké. Akármekkor $a$ is a ház körülötti lotunk (házhely), mindig talá. lunk helyet a konyhakerti veteményeink, virágágyaink és a gyümölcsfáinkon kivül, ahol megfér egynéhüny ribizke, málna, köszméte, szőlö, vagy szam óca (földi eper), stb, bokor, amik nagyon kevés gondozás mellett hasznot és élvezetet nyujtanak egé zz éven át. Ami a nagybani bogyós gyümölcsü termelést illeti, pedig egyik fóága az itteni farmeréletnek, elkezdve nyáron a szamócán és bevégezve a sző. lövel, mind olyan gyümölcsök, amelyeknek nem nagy nehézségekbe ütközik a pénzzé tételük.

Az alábbiakban felsorolt bogyós gyümölcsü csemeték mind erös növésü, $2-3$ éves példányok és a legjobban alkalmas fajok, bötermőségüknél fogva ugy házi használatra, mint piacra való termelésre.

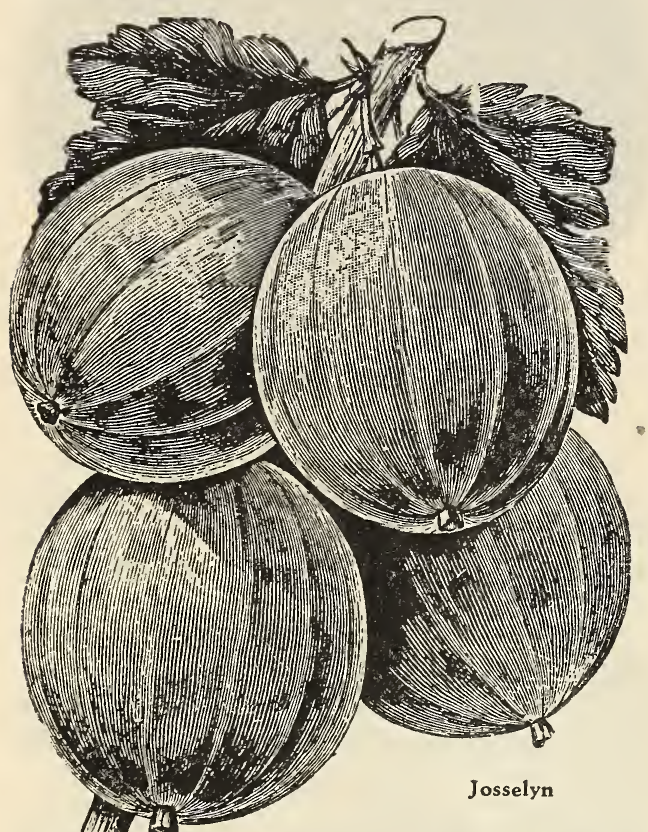

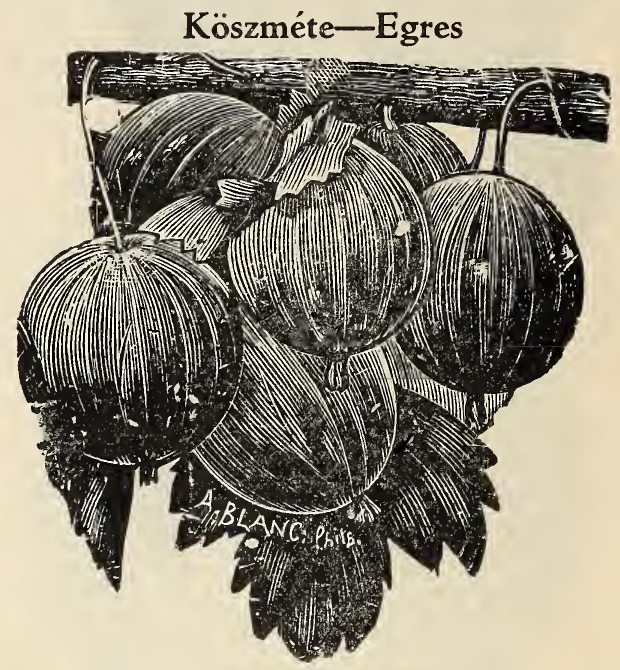

Downing-Köszméte

DOWNING. Jeles amerikai fajta, meglehetós korai, sárgás-zöld gyümölcsü. Finom asztali gyü. mölcs házi kertekben való termelésre. 1 darab 30c. Expresszen 10 darab $\$ 2.75$.

JOSSELYN. Kitünő izü, érésekor piros szinü amerikai egres. Bámulatos bőtermö, nagy, ovális alaku gyümölcsökkel. 1 darab 35c. Expresszen 10 darab $\$ 3.25$.

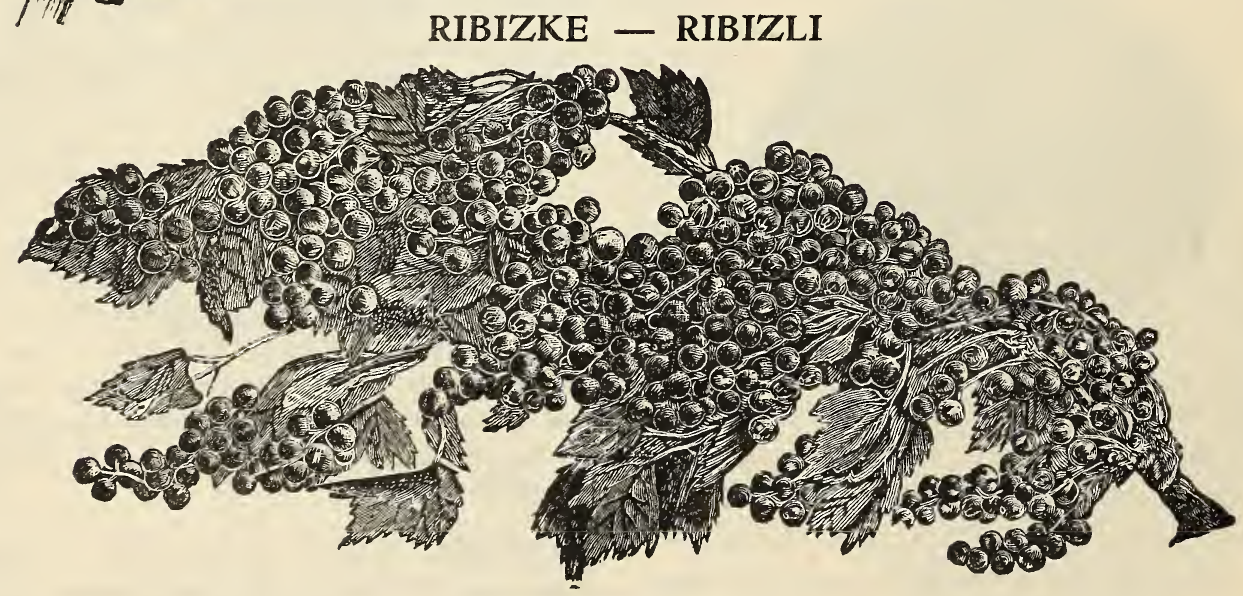

Ribiszke Vörös Nèmet

VÖRÖS NÉMET. Finom, bőtermő faj, ugy házi használatra, mint nagybani termelésre. 1 da rab $30 c ; 10$ darab $\$ 2.75$. 


\section{Ribizke-Ribizli}

FAY-FÉLE BÓTERMÖ. (Fay's Prolific.) Rendkivül hosszu fürtü és nagyon bőtermő ribizke-faj. Sötétvörös, igen nagy bogyókkal. Elsörendü piaci faj. 1 darab 30c; 10 darab \$2.75.

LONDONI PIACI. Kitünő market-faj, ugyszintén házi használatra is a legelsők közé tartozik. Gyönyörü piros szinü és kellemes izü gyümölcsökkel. 1 darab 30 c; 10 darab $\$ 2.75$.

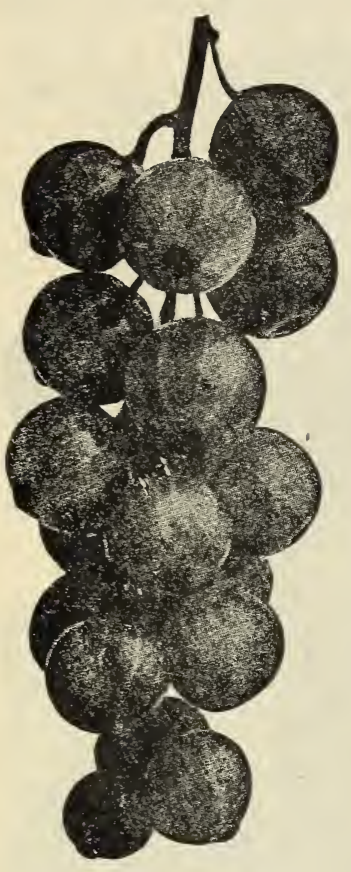

London Piaci

FEHÉR CSÁSZÁRI. Igen kedvelt fehér gyümölcsü ribizke. 1 da. rab 30c; 10 darab $\$ 2.75$.

FEKETE VICTORIA. Igen szép, közepes nagy gyümölcsü. Kitünö izü fekete ribizke faj. Nagyon bötermő. 1 darab 30c; 10 darab $\$ 2.75$.

\section{Saint Regis folytontermő Málna (Himpér)}

Ezen málna-ujdonság még csak 7 éve találtatott fel és máris oly nagy reá a kereslet, hogy a termelök nem tudnak eleget termelni, azaz szaporitani, hogy a vevöket $\mathrm{ki}$ lehessen szolgálni. Ezen málna-ujdonság szi nére és zamatjára ugyanaz, mint a magyarországi Piros Málna vagy Himpér (és arról is van fajoztatva), csak az köztük a különbség, hogy a magyarországi csak egyszer juliusban gyümölcsözik, ezen faj pedig juniustól egész hidẹg öszig, novemberig terem. Minden évben ujabb növéseken gyümölcsöt hoz. Nagy.

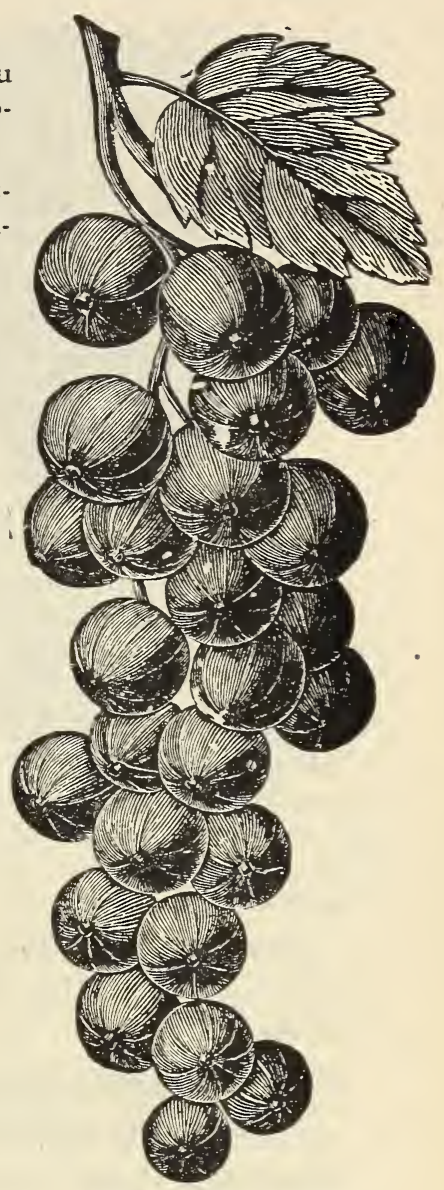

Fay-fèle Bötermõ Ribiszke

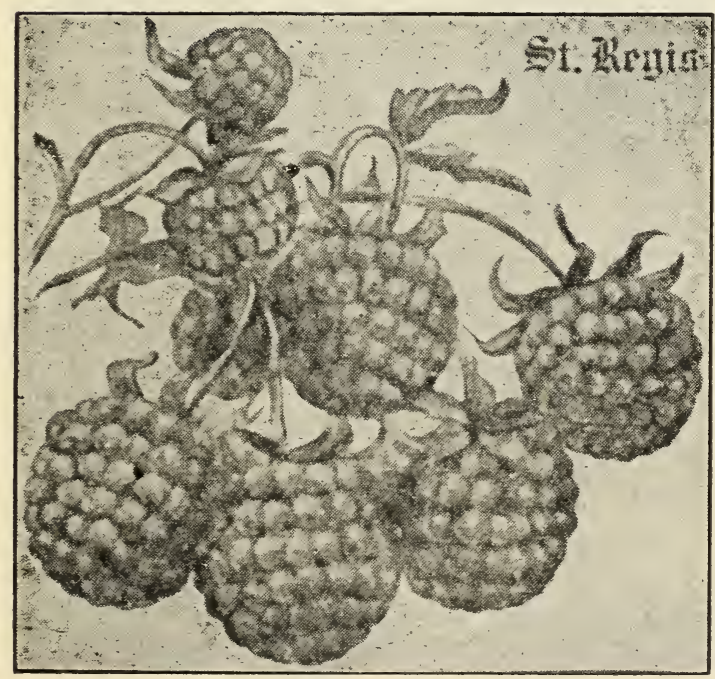

Folytontermõ Málna (Himpér)

ban piacra termelni nagyon gazdaságos, mert nagyon keresett gyümöles. Akinek tehát van egy kis kertecskéje, ennél hálásabb és jobb gyümölcsöt nem ültethet, mert néhány tucat palán. ta négy hónapon át ellátja asztalát iz. letes gyümölcsökkel. Postán 1 darab 10c; 10 darab 75c. Expresszen 50 da. rab $\$ 3.50 ; 100$ darab $\$ 6.00$.

\section{Málna-Himpér}

PIROS MÁLNA. A málnák királynéja. A legjobb európai remek vörös szinü és gyümölcsü málna, nagyon édes zamattal. A legjobb faj nagybani marketre való termelésre. Kitünóen szállitható. Családi kertek részére nélkülözhetetlen. 1 darab $10 \mathrm{c} ; 10 \mathrm{da}$. rab 80c. Expresszen 100 darab $\$ 6.00$. 


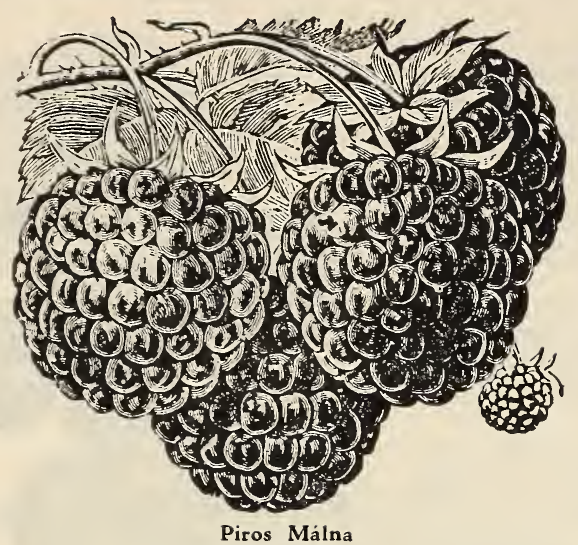

PALMER-FÉLE. Roppant dus termő, igen korai málna faj. Gyümölcsei finom zamatosak. A legmagasabb árakat hozza a marketon. 1 darab $10 \mathrm{c} ; 10$ darab $80 \mathrm{c}$. Expresszen 100 darab $\$ 6.00$.

MARLBORO. Nagy, világos piros gyümölcsü és kitünő minőségü faj. $\mathrm{Na}$ gyon korán érő, ugy, hogy a termelö korán csinál pénzt belöle. 1 darab $10 \mathrm{c} ; 10$ darab 80c. Expresszen 100 darab $\$ 6.00$.

SÁRGA MÁLNA. Remek sárga szinü és finom izü málna faj. Megnő bárhol. 1 darab $15 \mathrm{c} ; 10$. darab $\$ 1.25$. Expresszen 100 darab $\$ 10.00$.

\section{Szamóca-Eper Folytontermő Szamóca}

SUPERB. Ezen szamóca ujdonság teljesen eltérő a többi szamóca fajoktól, amennyiben ezen ujdonság nemcsak tavasszal gyümölcsözik, hanem egész hideg öszig folyton hozza a virágot és folyton érik a gyümölcse, különösen augusztus elejétől egész októberig a legbővebb termést adja. Egy régi vevőnk, aki 1920 tavaszán rendelt 50 darab palántát, azt irja elismerő levelében, hogy ezen a nyáron, azaz elültetésének második évén, az 50 darab palánta a családot egész nyáron ellátta gyümölccsel. Ezen faj nagybani termelése aranybánya, mert mikor már a többi fajok elgyümölcsöztek, 40-50 centet fizetnek kvartonként gyümölcséért a piacon (marketon). Az eladásra szánt palánták erősen gyökerezettek és már első évben hoznak gyümölcsöt. Postán 1 darab $10 c ; 10$ darab 60c. Expresszen 50 darab $\$ 1.75 ; 100$ darab $\$ 3.00$.

\section{Hamvas Szeder}

ELDORADO. Gyümölcsei nagy fürtökben jelennek meg az ágak végén. Rendkivül bötermö és finom zamatu. 1 darab 10c; 10 darab 80c. Expresszen 100 da. rab $\$ 6.00$.

BLOWER. A legbőtermőbb és legnagyobb gyümölcsü fekete málna faj. Egyike szintén azon bogyós gyümölcsöknek, amelyek a legtöbb pénzt hozzák a marke. ton. 1 darab 15c; 10 darab \$1.25. Expresszen 50 da. rab $\$ 5.50$.

SNYDER-FÉLE. Nagyon korai, édes, lédus gyümöl. csökkel. Csodálatos bőtermö. 1 darab 15c; 10 darab $\$ 1.25$. Expresszen 50 darab $\$ 5.50$.
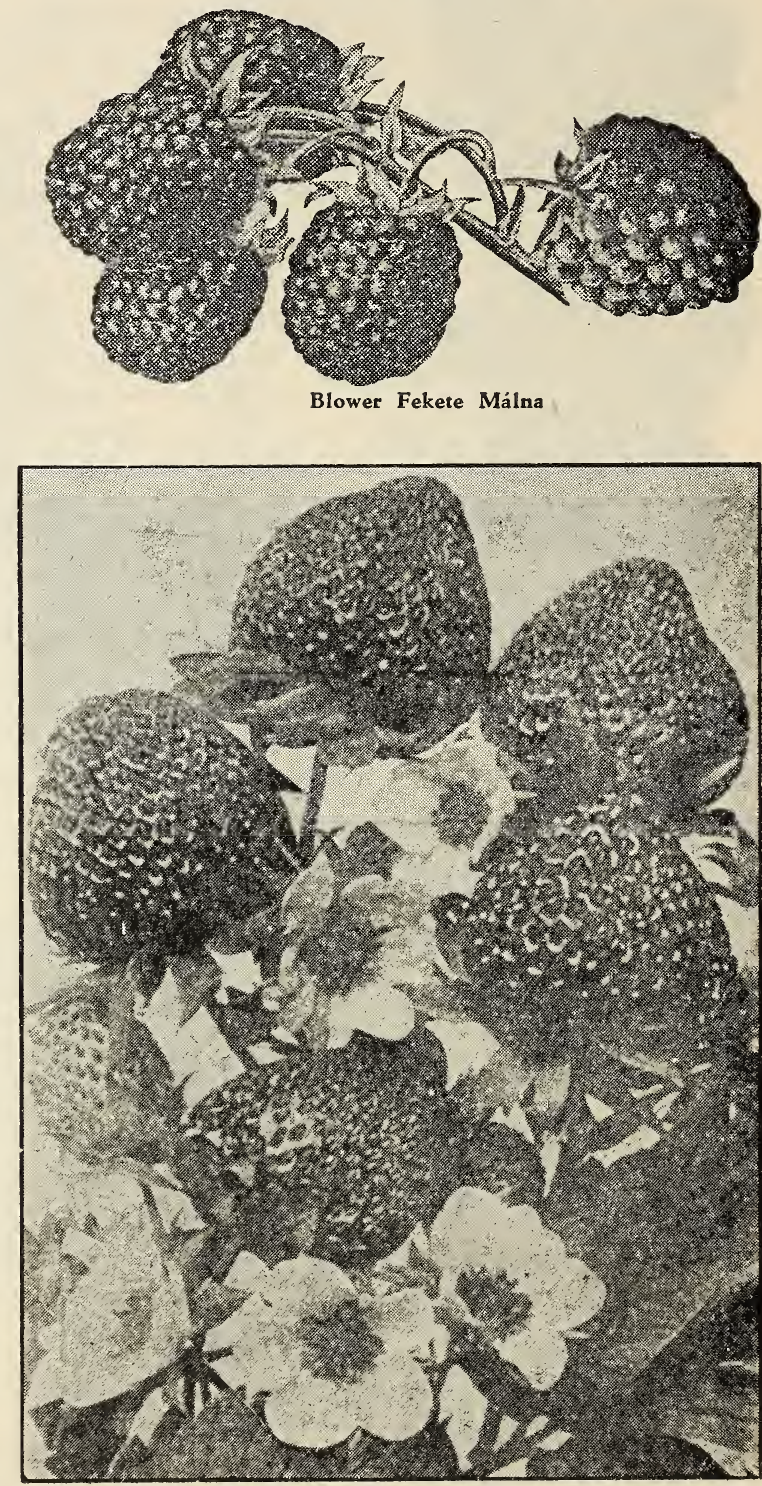

Folytontermő Szamóca (Eper) 


\section{SZAMÓCA-EPER}

A szamóca növények megérkezésük után vizbe mártandók és nedves földben tartandók, mig csak készen nem vagyunk azokat elültetni.

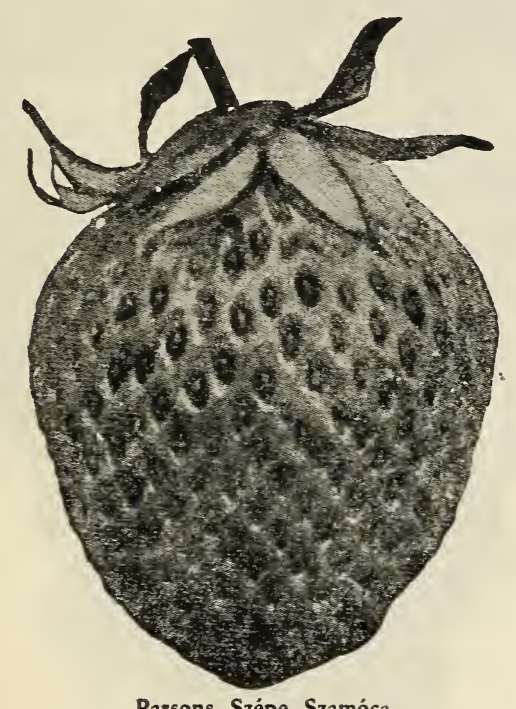

PARSON SZÉPE. Erős növésü és szép nagy gyümölcsöket fejlesztő szamóca faj. Középkorai. Kitünően szállitható. 10 darab 30c; 100 darab $\$ 1.25 ; 1000$ darab $\$ 9.00$.

BELT VILMOS. Extra nagyságu, finom izü, gyönyörü piros gyümölcsökkel. Nagyon bőtermő faj, ezáltal nagyban termelik. 10 darab 30c; 100 darab $\$ 1.25 ; 1000$ darab $\$ 9.00$.

ANANÁSZ. Ko. rai, igen bőtermo", élénk piros szinü és gyümölcsü faj. Házi használatra kitünő, remek ize által. Házi kertjeinkből elmaradhatatlan. $10 \mathrm{da}$. rab 30c; 100 da. $\mathrm{rab} \$ 1.25 ; 1000$ darab $\$ 9.00$.

DUNLAP TA. NÁCSOS. Egyforma szép gyümöl. csökkel, amelyek fényes pirosak. Kitünö faj befö. zésre. Korán érik és az érése hosz. szan tart. 10 da$\mathrm{rab} 30 \mathrm{c} ; 100 \mathrm{da}$.

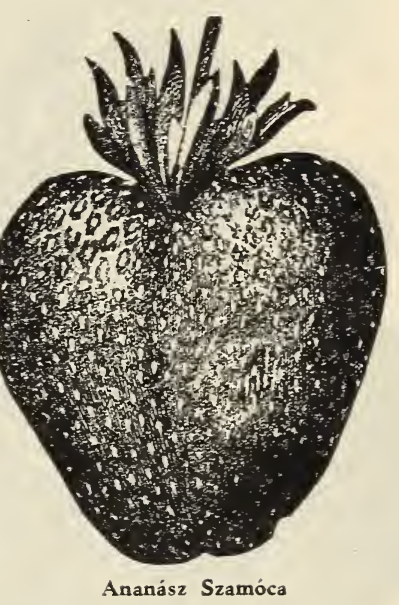
$\mathrm{rab} \$ 1.25 ; 1000$ darab $\$ 9.00$.

\section{SZÖLŐK}

Szőlöt általában mindenki ültet többet vagy kevesebbet, részint jó gyümölcseiért, vagy pedig háza körül befuttatva árnyék vagy lugas gyanánt; igy tehát ezen hálás gyümölcs sima vesszőről tenyésztett és az azokból kiválasztott legjobb 2 éves fajtákat tartalmazzák, amelyek dus gyökérzettel birnak, ugy, hogy egy-két év alatt kevés gondozás mellett termő. képesek lesznek.

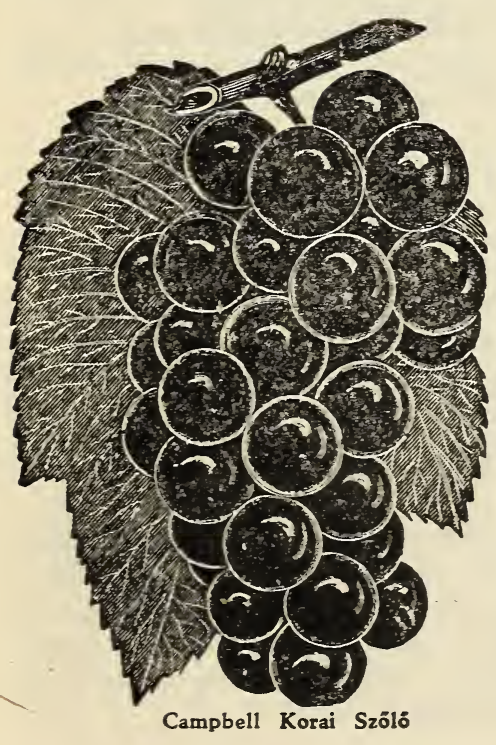

a) Fekete Fajok

KIRÁLY SZÖLÖ. Ujdonság! Erős növésü szőlő faj, fekete gyümölcsei bámulatos nagyságra fejlödnek ki, ennek folytán házi kertekben nagyon ajánlható asztali termelésre. Gyümölcsei felséges izüek és zamatuak. 1 darab 50c. Expresszen 10 darab $\$ 4.50 ; 100$, da. $\mathrm{rab} \$ 40.00$.

CAMPBELL KORAI. Kitünő minőségü asztali szőlö. Nagyon korai. Gyümölcsei nagyok, gömbölyüek, amelyek a legfinomabb édes izt szolgáltatják a fogyasztónak. 1 darab $45 \mathrm{c}$. Expresszen 10 darab $\$ 4.00 ; 100$ darab $\$ 35.00$.

WORDEN. A "Concord" fajnak egy leszármazottja, de gyümölcsei és fürtjei még nagyobbak, mint a Concordnak. Érése a Campbell koraié és a Concordé közé esik. 1 darab 30c. Expresszen 10 darab \$2.75; 100 darab $\$ 20.00$. 
DIAMOND. Elsőrendü fehér csemegeszőlö, a fekete Concord magonca, de jóval koraibb, mint az. Ugy a növény növése, mint a gyümölcse megegyeznek izben és nagyságban, csak mig az elöbbi fekete, ez fehér szőlö. Ez is szintén kitünő lugast szolgáltat. 1 darab $35 \mathrm{c} ; 10$ darab $\$ 3.00 ; 100$ darab $\$ 25.00$.

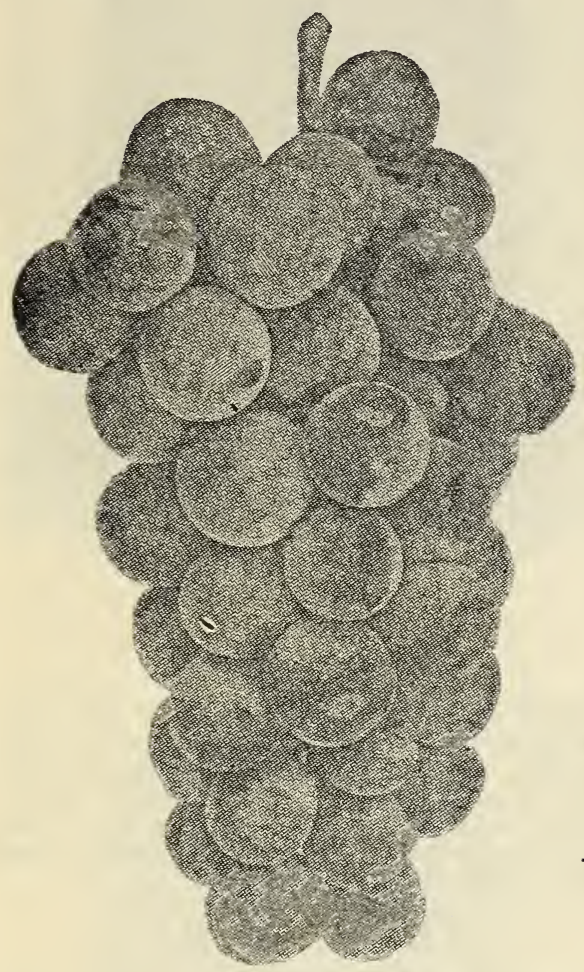

Brighton

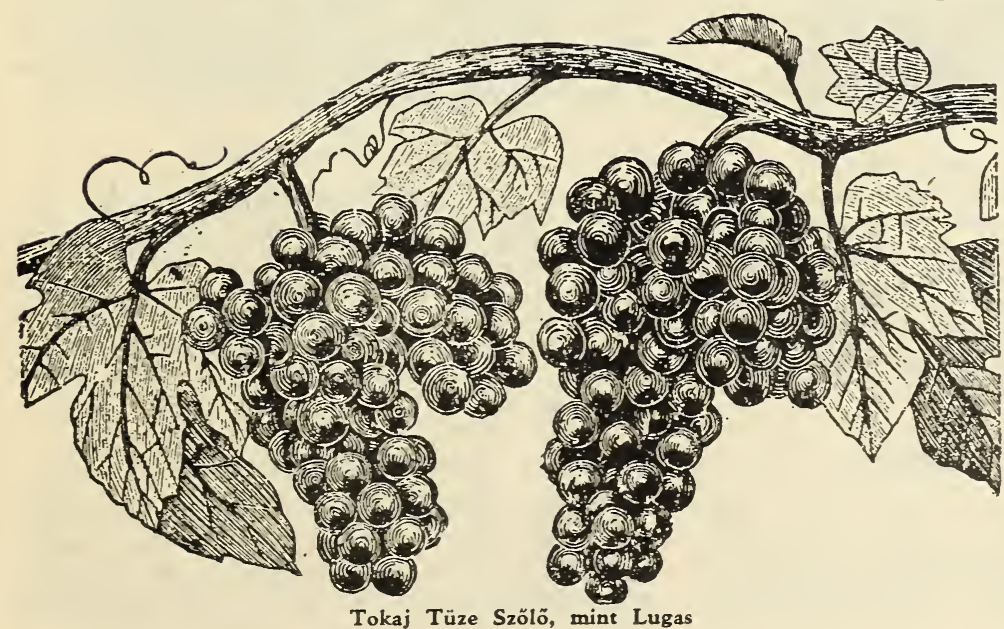

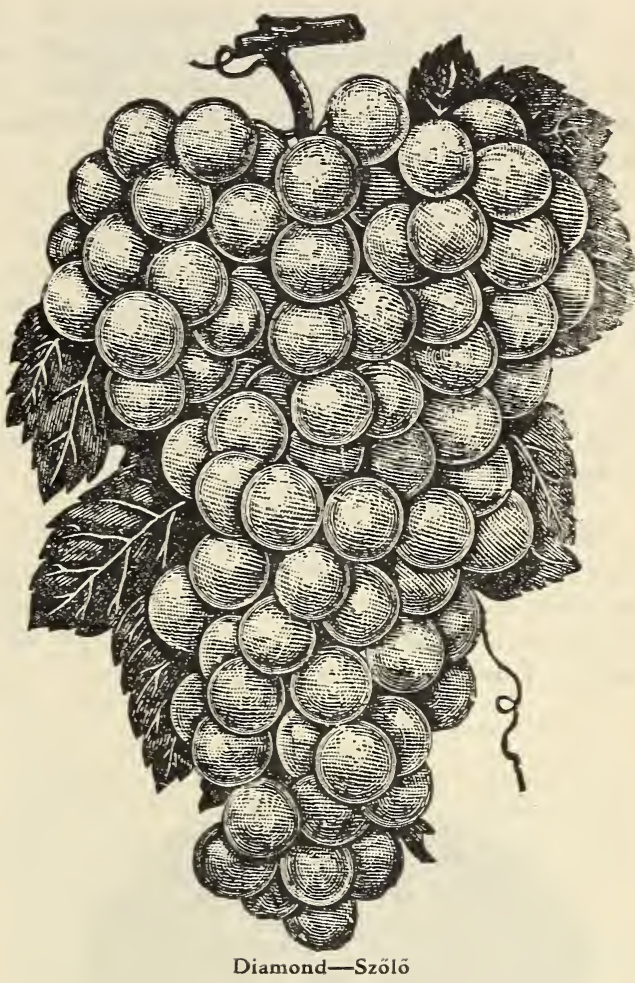

Európai Szőlők

TOKAJ TÜZE. Nagy, halvány piros, nedvdus gyümölcsü, mézédes asztali és mustszőlő. Gyümölcseért mesés árakat kapnak a csemegekereskedők. 1 darab 75c; Expressen 10 darab $\$ 6.50$.

MALAGA. Igen nagy, ovális alaku, halványsárga szinü csemege szőlő. Gyümölcsei roppant nedvdusak, méz édesek. 1 da. rab 75c. Expresz. szen - 10 darab $\$ 6.50$.

RIESLING. Magyarországon igen kedvelt mustszőlő. Fürtjei és bogyói középnagyok, az ize rendkivül kellemes és nedvdus. 1 da. rab 75c; 10 darab $\$ 6.50$. 


\section{DISZ- ÉS ÁRNYÉKFÁK}

Házak elé utcára, vagy házak körüli ültetésre legalkalmasabb lombfák, melyek a forró nyár folyamán hüvös árnyékot adnak. Az eladásra menő példányaink átlag 6-10 láb magasak, ugy, hogy rövid idő alatt a kiültetésük után szép árnyékot nyujtanak. Csak Expresszen vagy teheráruként szállithatók.

\section{Akácfa}

PIROS VIRÁGU AKÁCFA, amelyet nagy, piros virágaiért kedvelnek. A házak elött egyesben kiültetve a gyepbe, ugy a virágzáskor, mint máskor kitünően fest. Virágja olyan, mint a fehér akácé, csak vagy három oly nagy fürtben, 45 láb magas törzsbe oltott szép 2 éves példányok. 1 darab $\$ 2.00 ; 10$ darab $\$ 17.50$.

FEHÉR VIRÁGU AKÁC. Szülőhazánkból és sokunknak kedves emléket visszaidéző, jól ismert árnyékfa, illatos fehér virágokkal, amelyek nagy fürtökben jelennek meg az ágakon. 8-10 láb magas. 1 darab $\$ 1.00 ; 10$ darab $\$ 9.00$.

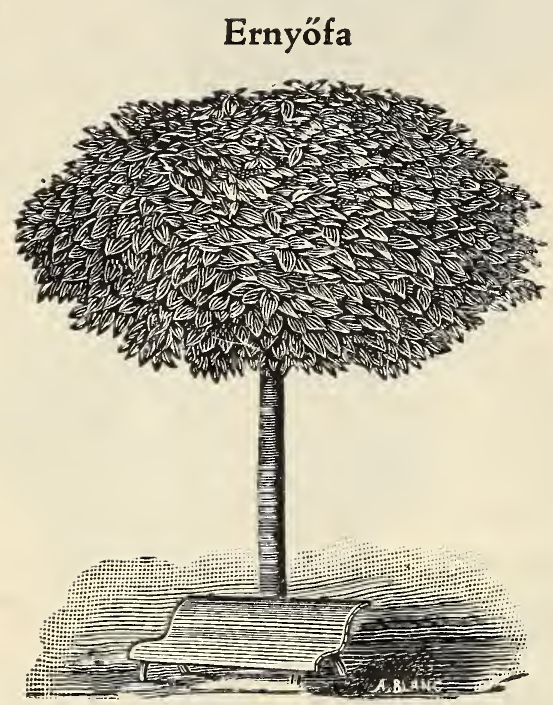

CATALPA BUNGII ERNYÓFA. Remek, nagyon szép, egyformán növő koronáju diszfa, amely házak elött a gyepben nagyszerüen fest. Elmaradhacatlan uj házak elé, de meg bármely ház hoz, mert szép, ernyőalaku koronájával emeli a ház szépségét. $\mathrm{Az}$ ernyőfát, a szomoru eperfát és a rózsaszinü akácfát különösen ajánljuk házaink diszitésére. Szép 6-8 láb magas példányok. 1 darab $\$ 2.00 ; 10$ darab $\$ 18.00$.

\section{Eper vagy Szederfa}

MORUS RUBRA. Fekete eperfa, szép, nagy levélzettel és gyümölcsökkel. Ugy mint az előbbi, kedves árnyat adó $\mathrm{fa}$ házak körül. 6-8 láb ma. gas, oltott nagy gyümölcsü. 1 darab $\$ 1.00 ; 10$ darab $\$ 8.00$.

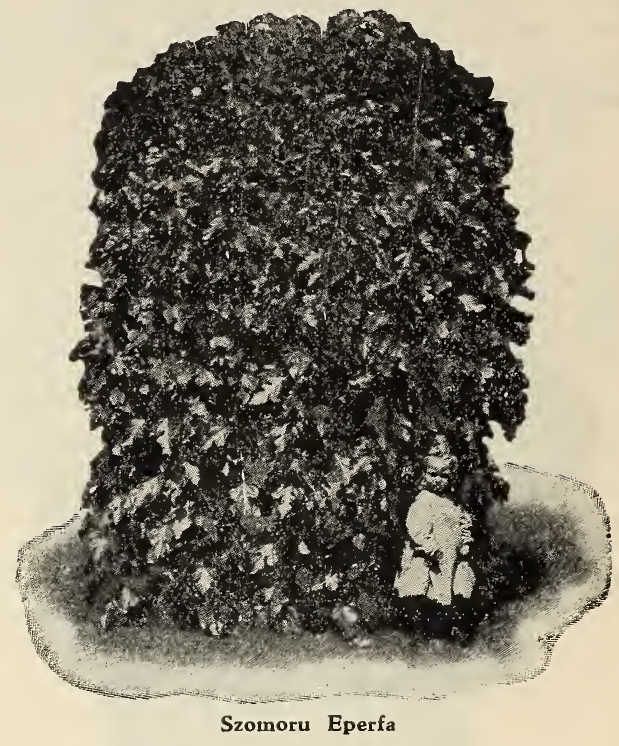

\section{Szomoru Eperfa}

MORUS PENDULA. Elsőrendü diszfa. Nagyban használják a házak elé gyepbe, mint egyes különálló fát, mert mint ilyen, lecsüngő ágaival remek képet kölcsönöz a ház elejének. Nagyon ajánljuk mindenkinek, különösen uj ház épitésénél. elmaradhatatlan. 6-8 láb magas. 1 darab $\$ 2.50 ; 10$ darab $\$ 22.50$.

\section{Szomoru Füzfa}

SALIX BABYLONICA. Szomorufüz. Szép, magánálló $\mathrm{fa}$, a földig lecsüngő ágazattal, amely nagy árnyékot ad a ház kerületének, Kissé ned. ves talajban diszlik a legjobban. 8-10 láb magas 1 darab $\$ 1.00 ; 10$ darab $\$ 8.00$.

\section{Édes Gesztenyefa}

CASTANEA AMERICANA. Amerikai édes gesztenyefa. Nagy hasznot hozó fa a gyümölcse által. Ha van a földjeinken olyan hely, ami másra alkalmatlan, ültessünk rá gesztenyefát, ami később meghozza a vele járó fáradságot. Ültessünk különösen legelökre. Mint szerszámfa is nagyban keresett. 4-5 láb magas. 1 darab $\$ 1.00 ; 10$ da. rab $\$ 9.00$.

\section{Japáni Gesztenyefa}

JAPÁN GESZTENYEFA. Nagy, édes gesztenyékkel. Nagyon hamar gyümölcsöző faj, a melyből sok pénzt lehet előállitani. Amerika bár. mely részében megnő és rövid idő alatt óriási fává fejlödik. 1 darab $\$ 1.25 ; 10$ darab $\$ 10.00$. 


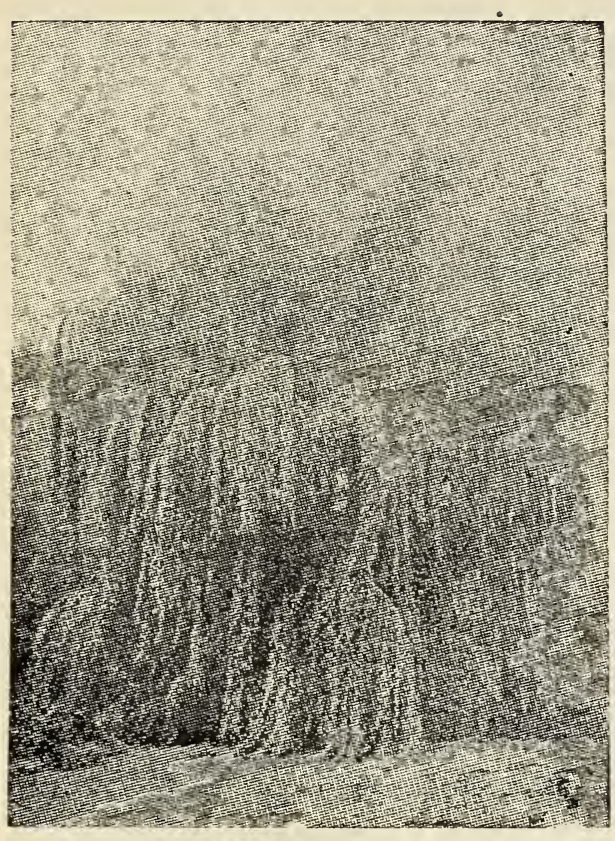

Szomoru Füzfa.

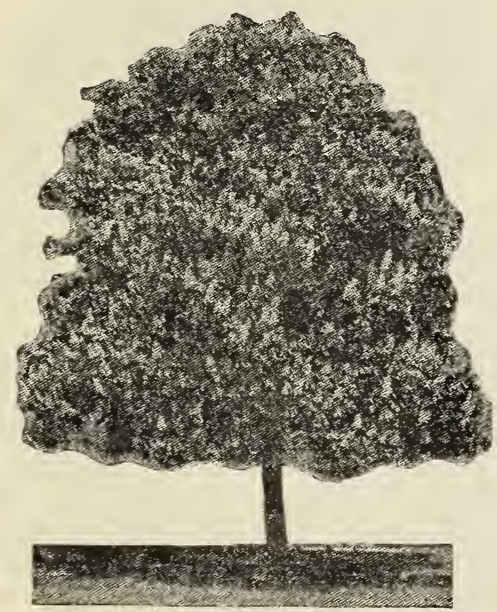

Vadgesztenyefa?

\section{HÁRSFA}

TILIA GRANDIFLORA. Nagyon kedvelt árnyékfa; szép lombozata miatt házak körüli használatra. Jó illatu virágai összeszedve és megszáritva az ugyncvezett hársfa herbatét vagy teát szol. gáltatják. 8-10 láb magas. 1 darab \$2.00; 10 darab $\$ 17.50$.

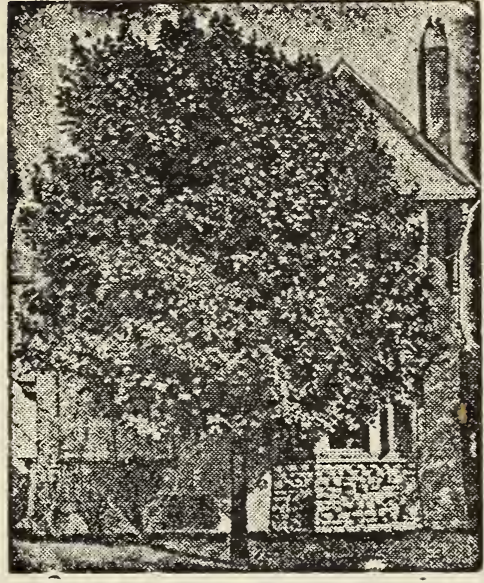

Jávorfa.

\section{JÁVORFÁK}

ACER DASYCARPUM. Ezüst jávorfa. Nagyon gyorsan növö árnyékfa. Levelei alsó lapja ezüstös. Nagyon ajánlható házak elé ugy egyesnek, mint utca mentén sorfának. 8-10 láb magas. 1 darab $\$ 2.00 ; 10$ darab $\$ 17.00$.

ACER SACHARINUM. Cukor-jávor, amelyböl Amerikában az ugynevezett "Sugar Syrup"-ot veszik. Ugy egyesben kiültetve, mint sorfának, utca hosszat házak elé, nagyszerü lombot, árnyékot ad. Itt Amerikában "Sugar Maple" név alatt ismeretes. 8-10 láb magas. 1 darab $\$ 2.00$. 10 darab $\$ 17.00$.

ACER PLATNOIDES. Jókori jávorfa. Remek, tökéletes koronát hozó árnyékfa. Az ágai nem törékenyek, ugy mint más iharfáé. Dus, gazdag lombozattal. Nagyban használjảk házak elé, utca sorfának is, mert mint ilyen, szép külsöt kölcsönös a ház elejẻnek. 8-10 láb magas. 1 darab $\$ 2.50,10$ darab $\$ 22.50$.

ACER SCHWEDLER. Elsörangu diszfa. Gyönyörü vérvörös szinü lombozattal és levélzettel. $6-8$ láb magas. 1 darab $\$ 3.50 ; 10$ darab $\$ 30.00$.

\section{NYÁRFÁK}

POPULUS MONILIFERA. Rezgönyárfa. Gyors nō. vésü, dus lombozattal biró "rezgő levelü" nyárfa. Megnö bárhol, ahol más fák nem diszlenek, különösen szeret nedves talajt, ugy, mint a füzek. 8-10 láb magas. 1 darab $80 c ; 10$ darab $\$ 7.00$.

POPULUS ALBA NIVAE..... Valódi ezüst nyárfa. Remek, mint magánálló egyes árnyékfa, dus, gazdag lombo. zattal. 8-10 láb magas. 1 darab $\$ 1.00$; 10 darab $\$ 8.00$.

POPULUS PYRAMIDALIS. A valódi sugár jegenye nyárfa. Sarokban festöien mutat. 8-10 láb magas. 1 darab $\$ 1.00 ; 10$ darab $\$ 8.00$. 


\section{Nyirfa}

BETULA ALBA LACINIATA. Ezen gyönyörü lecsüngö fa egy válfaja a magyarországi nyirfának, csakhogy ez finoman vágott levelü, agai lecsüngök es arra a magyarországi közönségesre van nemesitve, vagyis oltva. 8-10 láb magas. 1 darab \$2.50; 10 darab $\$ 22.50$.

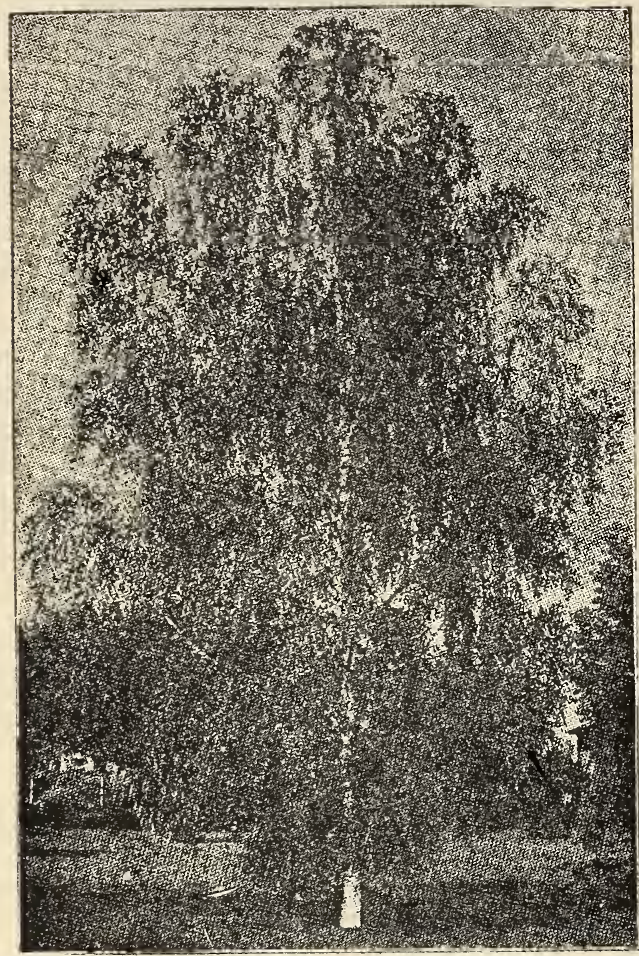

Nyirfa

\section{Platánfa}

PLATANUS ORIENTALIS. Hatalmas nagyságra növő lombfa, gyönyörü koronával. Nagyban használják ugy sorfának utcákra, mint házak elé magánálló árnyékfának is. 8-10 láb magas. 1 darab \$2.00; 10 darab 18.00 .

\section{Szivarfa}

CATALPHA SYRINGAFOLIA. Igen nagy levelü s gyors növésü, kedvelt lombfa, amely ugy sorfának, mint magánálló fának kitünően alkalmazható. Szép nagy fehér virágai elhullta után hosszu, a "virginia" szi. varhoz hasonló magfürtök jelennek meg a fákon, ami után kapta az angol "szivarfa" elnevezését is. 8-10 láb magas. darab $\$ 1.00 ; 10$ darab $\$ 8.00$.

\section{Szilfa}

ULMUS AMERICANA. Kecses levelü, szép koronáju árnyékfa. Alkalmas ugy sorfának utcákra, de még jobban mint magánálló fának, nagyobb terjedelmü helyekre. $8-10$ láb magas. 1 darab $\$ 1.50 ; 10$ darab $\$ 14.00$.

\section{Tölgyfa}

QUERCUS PEDUNCULATA. Valódi impozáns csertölgy. Szép lombozatával remek magánálló fát alkot. $6 \rightarrow 7$ láb magas. 1 darab $\$ 2.00 ; 10$ darab $\$ 17.00$.
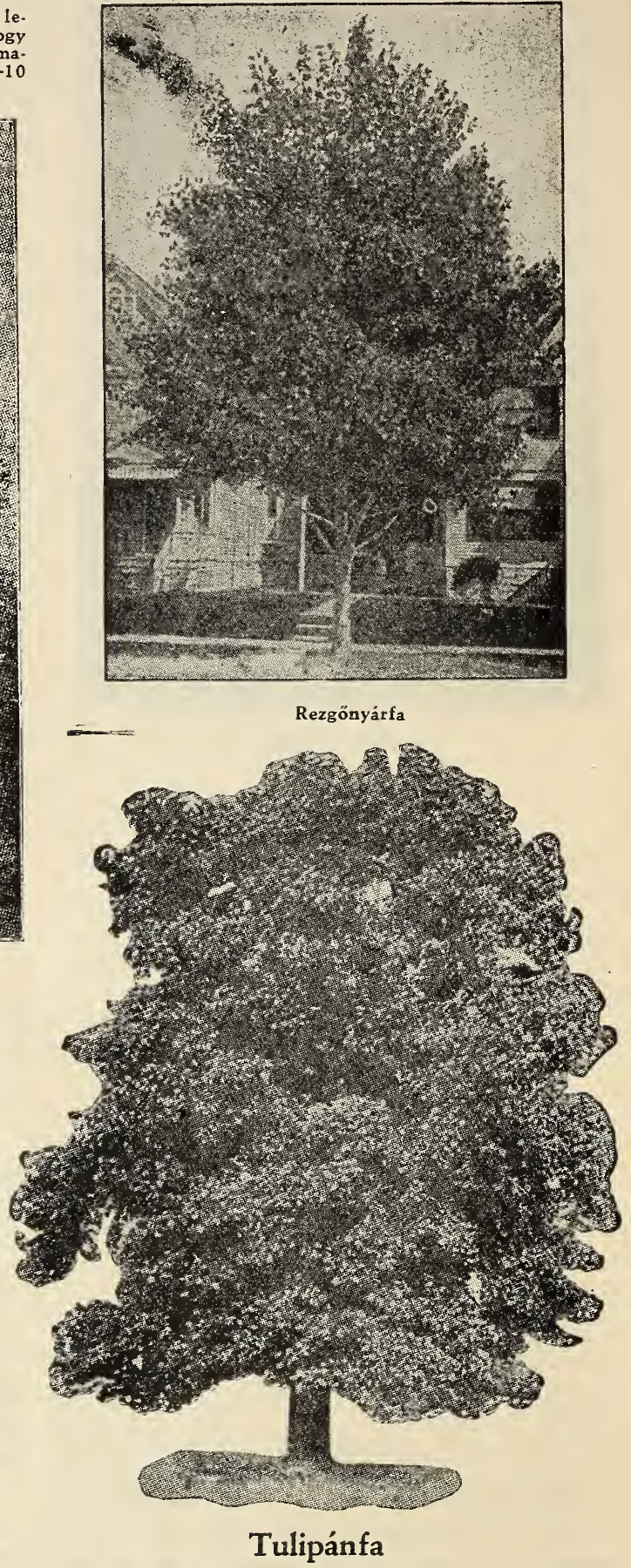

LILODENDRON TULIPIFERA. Pompás, igen diszitő hatásu árnyékfa. Zöldes narancsszinü, a tulipánhoz hasonló alaku virágokat hoz. $6-8$ láb magas. 1 darab $\$ 2.00 ; 10$ darab $\$ 17.50$. 


\section{FENYÖFÁK}

A tü-levelüiek képezik legszebb diszleteinket: télen-nyáron egyaránt szépek a kertben, udvarokon, stb. Megnőnek bármely talajban. A kertészetünkből kiküldött példányok át. lag két láb magasak, amely korban legbiztosabb a megfogamzásuk. Szállitásuk Expresszn vagy teheráruként eszközöltetik.

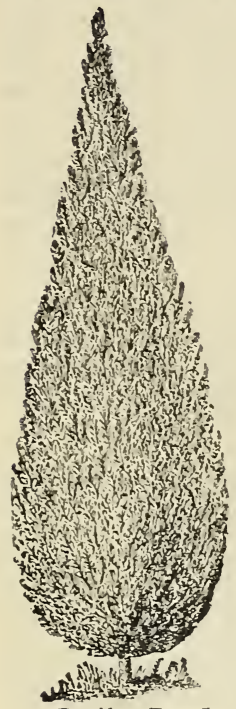

\section{Cidrus vagy Életfa}

THUYA OCCIDENTALIS. Ott, hol örökzöld kerités vagy cserje kivánatos, vagy temetőben kedveseink sirja körül, a legalkalmasabb az életfa. Örökzöld lombozata és szép gula alakja mindig különös hatást kelt. 2 -3 láb magas. 1 darab $\$ 3.00 ; 10$ darab $\$ 27.50$. 3-4 láb magas $\$ 4.00$; 10 darab $\$ 37.50$.

\section{Ezüstfenyő}

PICEA ARGENTEA. A legszebb és legnemesebb diszfenyő fánk. Növése erőteljes, feltünő szép ezüst szinü tükkel. Házak elött vagy körül remekül mutat több diszeserjék kö. zött 2-3 láb magas. 1 darab $\$ 20.00$, 10 darab $\$ 170.00$.

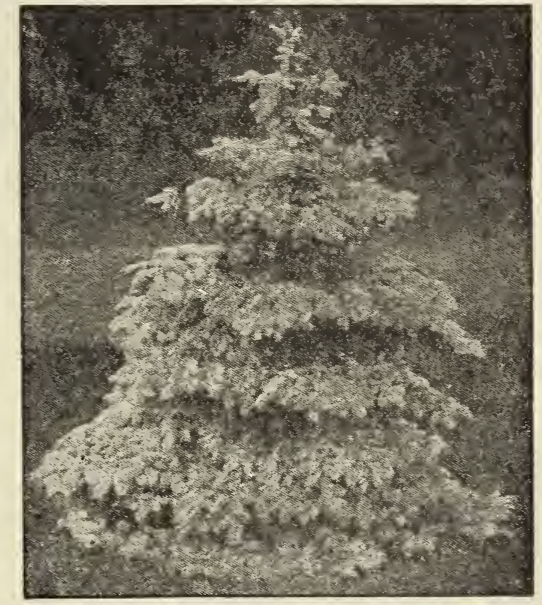

Ezüstfenyö

\section{Boróka Fenyö}

JUNIPERUS HYBERNICA. Keskeny, oszlopalaku növésü, vörös borókafenyő. Nagyon alkalmas sirokra ültetve disz gyanánt. $1-2$ láb magas. Darabja \$2.00; 10 darab $\$ 17.50 .2-3$ láb magas $\$ 3.00 ; 10$ darab $\$ 25.00$.

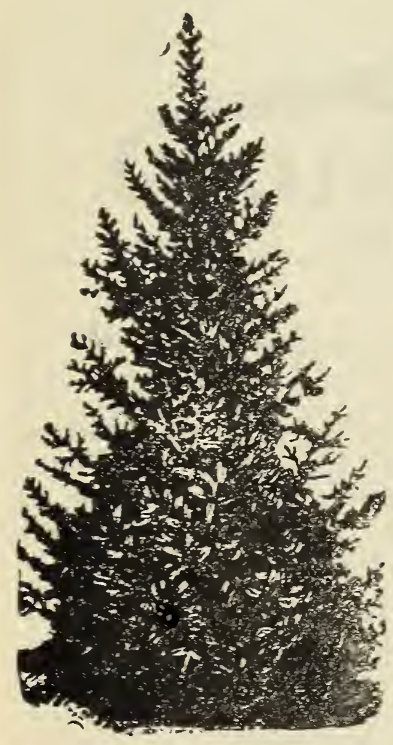

Luc vagy Vörōs Fenyő

\section{Erdei Fenyö \\ PINUS AUSTRIACA.} A közkedvelt magas növésü $\mathrm{fe}$ nyő vagy osztrák fenyő. Hosszu, sötétzöld szinü tükkel. 2-3 láb magas. Darabja $\$ 4.00 ; 10$ darab $\$ 37.50$.

\section{Hemlock Fenyo"} TSUGA CANADENSIS. Gyönyörü diszfenyő, kecsesen lecsüngő finom tükkel. 2-3 láb magas. Darabja $\$ 3.50$; 10 darab $\$ 30.00$.

\section{Selyem Fenyő}

PINUS STROBUS. Gyönyörü terebélyessé fejlödött, simahéju fenyő faj. Selyemszőrü finom, puha levélzettel. 2-3 láb magas. Darabja $\$ 2.00 ; 10$ darab $\$ 27.50$. 3-4 láb magas $\$ 4.00 ; 10$ da. $\mathrm{rab} 37.50$.

\section{Lùc- vagy Vörös Fenyő}

PINUS EXCELSA. A közönséges hazai vörös fenyő. Megnő bárhol és növése gyors. A legszebb "Karácsonyfát" szolgáltatja. 3-4 láb magas. Darabja $\$ 3.50 ; 10$ darab $\$ 30.00 ; 4-5$ láb magas $\$ 5.00 ; 10$ darab $\$ 47.50$. 


\section{Rovarölő és fecskendező szerek}

ROVAR POR (Slug Shot). Nélkülözhetetlen por alaku rovarirtó szer, minden kertészkedőnek kéznél kell lenni. Biztos eredménnyel használtatik mindennemü konyhakerti növények elleni rovarok ellen, u. m.: burgonya bogarak, káposzta hernyók, ugorka, dinnye, sütő- és fözelék-tök bogarak ellen.

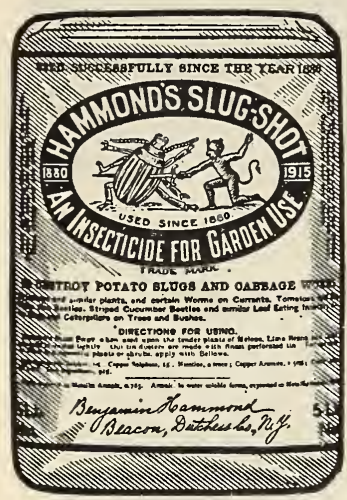

Rovar Por

5 fontos csomag

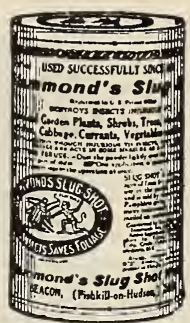

Rovar-por 1 fontos csomag

Továbbá kitünő szer rózsa, ribiszke, köszméte és szamóca hernyók ellen, akár por formában van ellenük használva, akár vizben fel. oldva és befecsken. dezve. A födolog az, hogy már időben be legyenek hintve a növények, levelek és bokrok, mielött a rovarok nagyban elszaporodtak. - Áruk: 1 fontos csomag (a tetején szitaszerü háló. zattal a behintésre) postán 45c; 5 font Expresszen $\$ 1.50$.

ÓLOMPOR VEGYÜLÉK (Arsenate of Lead.) Ezen rovarölő szer szükséges volna ugy farmokon, mint házi kertekben. Bárminek használják és bármily mennyiségben, a növénynek nem árt, de a rovarokat azonnal elpusztitja. Burgonya, káposzta, ugorka, dinnye, szölö, gyümölcsfa fecskendezésre, vizbe oldva kell használni. 1 fontos cso. $\operatorname{mag} \$ 1.25$.

NÖVÉNYPOR (Hellebore.) Mérges növény kivonat. Biztos halál minden levélevő rovarokra, hernyókra, u. m.: rózsa, köszméte, ribiszke, burgonya (krumpli) és káposzta leveleken. ..Egy fontos csomag $65 \mathrm{c}$.

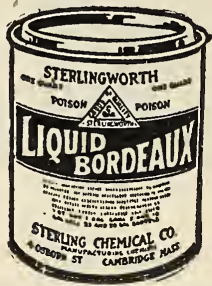

BORDÓI LÉ (Bordeaux Mixture.) Ugy mint a fen. tiek, mindennemü gyümölcsfák, szőlök, diszfák és diszbokrok, stb. befecskendezésére. - Expresszen 1 kvart $\$ 1.00$.

KÉNPOR (Sulphur.) Méz. és liszaharmat pusztitására. 1 font $75 c$.

MÉSZKÉN VEGYÜLÉK (Lime and Sulphur.) Akinek akár termő, akár fiatal növő gyümölcsfái vannak, nem szabad elmulasztani minden tavaszon ezen vegyülékkel a fákat befecskendezni. Ez a vegyülék, amely a fák héjján élösködő, rátapadt rovarokat elpusztitja. Használati utasitás minden dobozzal. 1 fontos doboz postán $75 \mathrm{c} ; 5$ fontos doboz postán $\$ 3.00$. Expresszen $\$ 2.75$.

\section{Gatch-em-Ghow}

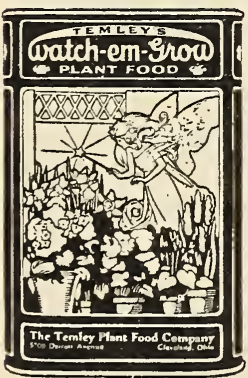

"Watch'em Grow" Növénytápszer

\section{"Watch 'em Grow" Növénytápszere.}

Adjon virágjainak uj életet és szépséget "Watch'em Grow" nö. vénytápszerrel. Ettől az ön kedvenc házi vagy kerti virágjai csodásan nőnek! A Wach'em Grow növénytápszernek jellegzetes és majdnem azonnali hatása az ön növényeire, bokraira és virágjaira ugyszólván bámulatkeltő. Erőssé és ellenállóvá teszi öket. És ahogy nőnek, pom. pás és egészséges uj hajtások fejlödnek, szinük is szebb lesz.

Használható egész éven át. Használja télen a fernek, begoniák és jácintok növesztésére - és nyáron a kerti növényekre, a gumós virágokra, a rózsákra a bokrokra, a fákra és a pázsitra. Oldjon fel egy kávéskanállal egy kanna vizben, amikor csak megöntözi a kertet.

1 adag 10c; kisebb pakli 25c; 8 oz. 50c. 



\section{MEGRENDELó IV.}

\section{Kállay Testvérek}

\section{PAINESVILLE, LAKE COUNTY, OHIO.}

Megrendelésekkel együtt, igen szépen kérjük az összeg szives be(Registered) levélben.

Fontos. Nem határoz, bármily gyakran is irnak, sziveskedjenek ponto- san kiirni a teljes cimet, mivel a hibás cimzés folytán sok kellemetlenség történik.

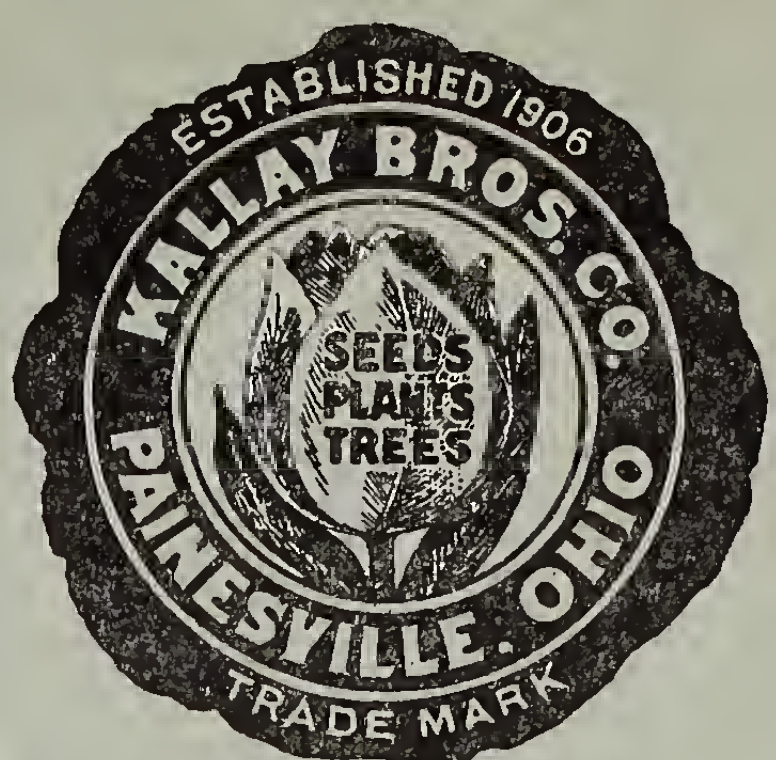

Név-Name

Utca és Szám )

Street and No.)

P. O. Box

Város )

Post-Office )

R. F. D. No

County.

Allam

State
Rendelés No

Kelt

Mellékelt Összeg

P. O. Money Order $\$$.

Check

Készpênz

Bélyeg

öSSZEG $\$ \ldots \ldots \ldots \ldots \ldots \ldots \ldots \ldots$

Express vagy Freight

HA HELYBEN NINCS EXPRESS, VAGY TEHERALLOMLÁS. AKKOR IRJA KI PONTOSAN AZON VAROS NEVÉT, AMELYBEN ÖNÖKHÖZ A LEGKÖZELEBBT. EXPRESS, VAGY TEHERALLOMAS VAN.

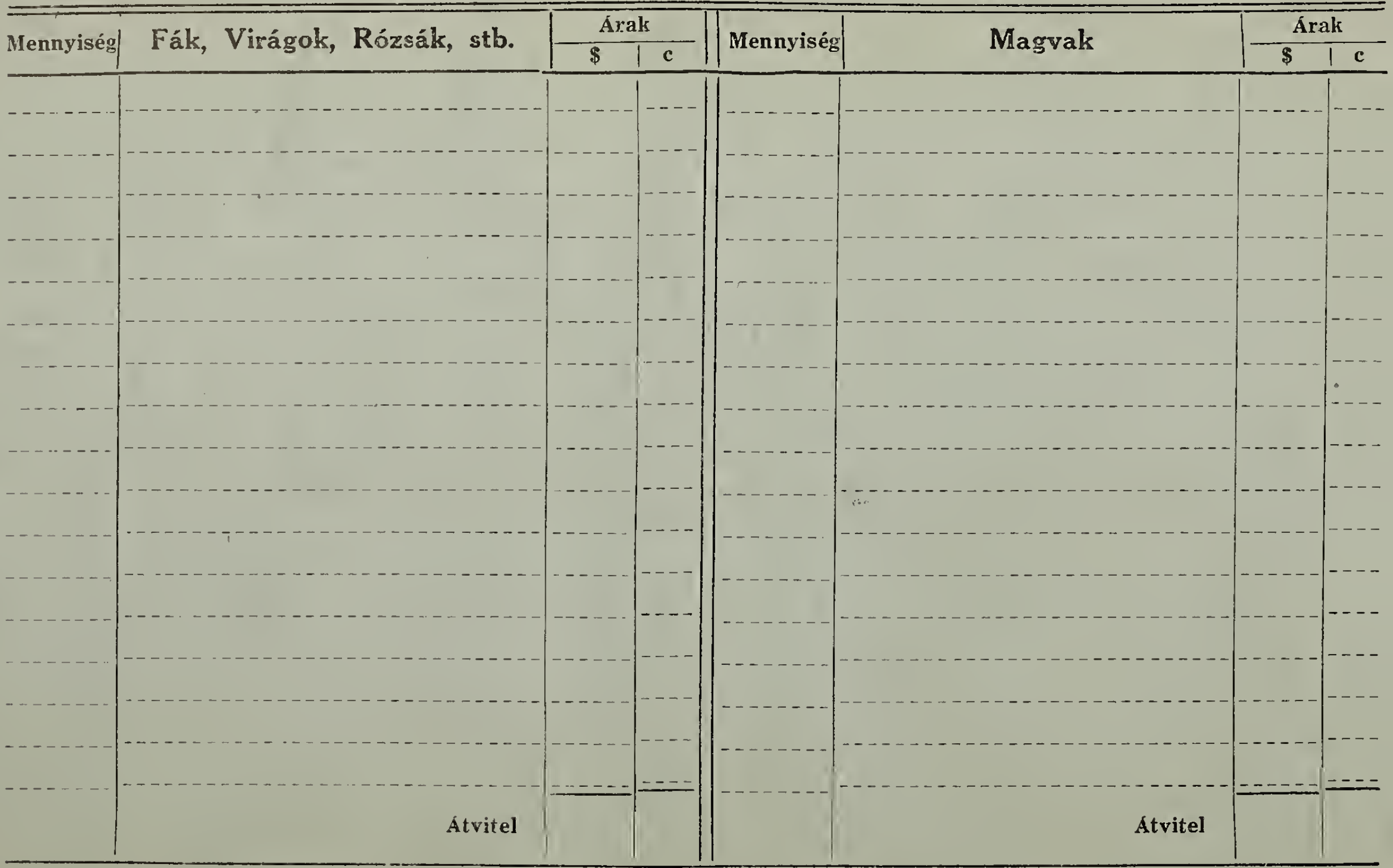




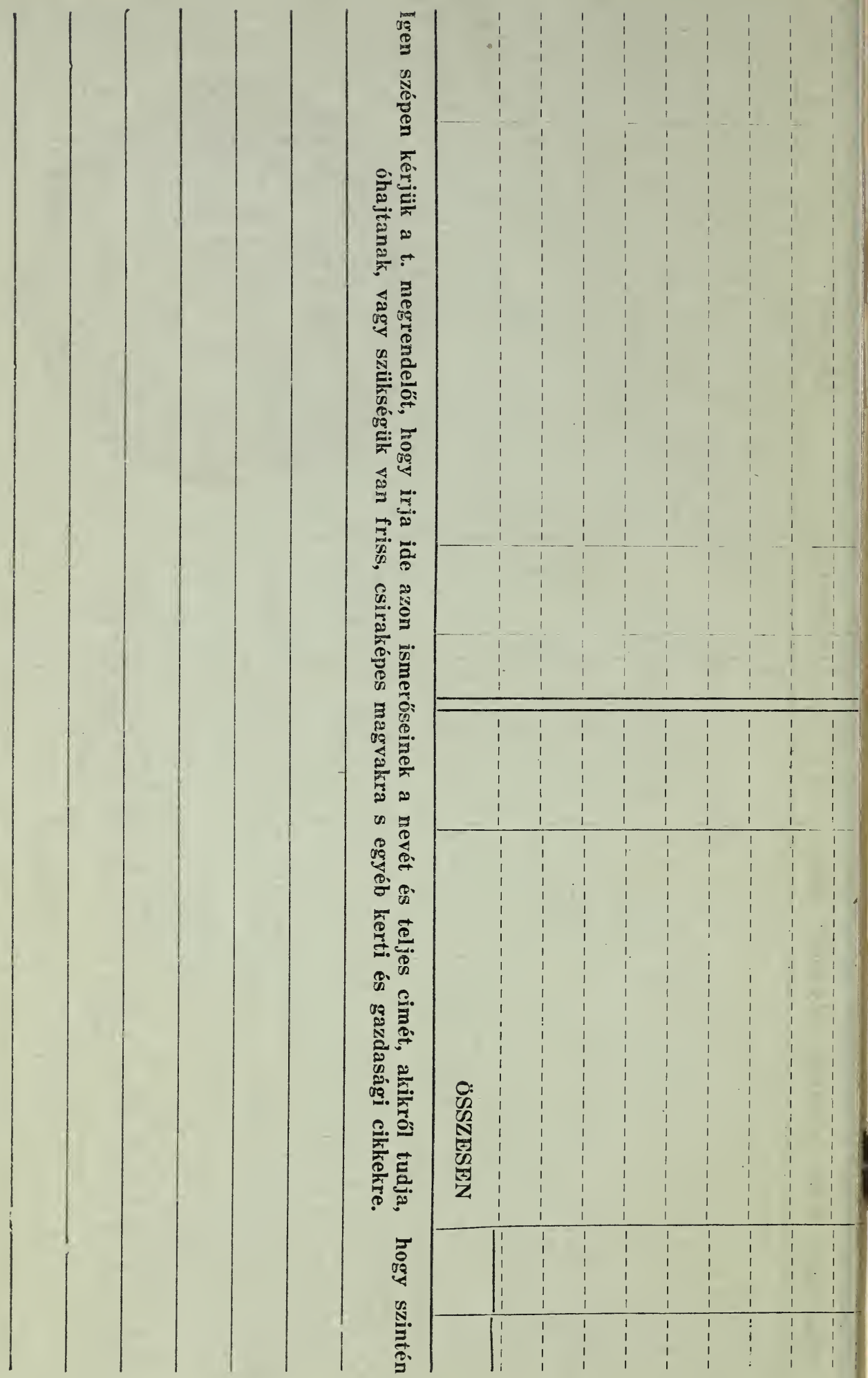




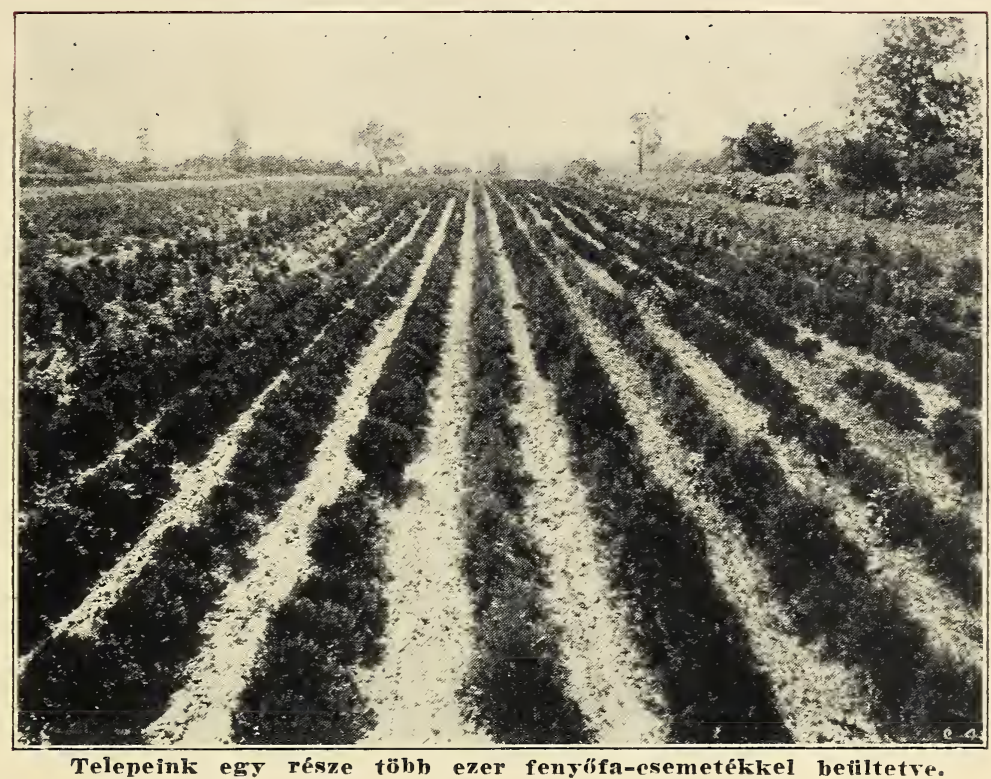

\section{TARTALOM JEGYZÉK}

Cim

Elöszó

Szállitási szabályok

Fizetési feltételek

\section{KONYHAKERTI} MAGVAK.

Bab fajok

Borsó fajok

Dinnyék

Dohánymag

Hagymafélék

Káposzta fajok

Karfiol

Kalarábé

Mák

Napraforgó

Metélö petrezselyem

Petrezselyem

Pasztinák

Paprikák

Paradicsom

$5-9$
$10-11$
$12-13$
$14-16$
$16-19$
19
20
20
20
21
21
21
$22-23$

\section{RÉPAFA JOK.}

Sárga vagy murok répa ,- 25 Cékla vagy vörös répa -- 26

Cékla vagy voros répa Retek

Rabarbara 28

Spárga -

Sóska

Spenót

Saláta fajok $30-31$

Tökfa jok

Tojás gyümölcs .............. 32

Tengeri asztali _................ 33

Ugorka - 34

Peanuts fajok

Füszer növény magvak 36

\section{BURGONYÁK ÉS VEGYES GYÖKEREK}

Gombacsira

Rabarbara

\section{Spárga gyökér Torma gyökér \\ GAZDASÁGI MAGVAK.}

Takarmányrépák _a $37-38$ Mezei tengeri Buzafajok $\mathrm{Zab}$

Árpafajok _... 40

Lohere fajok _.......41-42

Muhar fajok

Köles

43

Pohánka (v. hajdina) _...43

Napraforgó

Takarmány tök

Seprö cirok

Bükköny fajok

Timothy fümag

Takarmányfü

Pázsit fükeverék

Gazdasígi és kerti szerszámok

\section{VIRÁGMAGVAK.}

Árvácska

Balzșamina

Bá jvirág

Bársonyvirág

Buzaviràg

Szagos borsó _._....... 51

Chrysanthemum _._._. 51

Cosmos

Colendula - 52

Diszdohány

Diszmák

Égöszerelem

Gaillardia 5

Hajnali menyasszony .... 5

Heliopsis

Kakastaré j

Kéknefelejts

Mályvarózsa

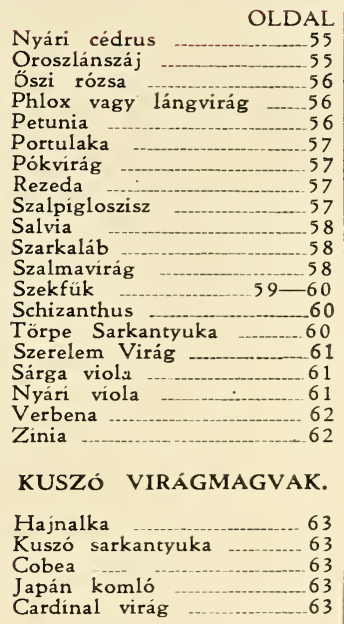

SZOBA VIRÁGOK.

\section{Abutilon}

Amarilisz

Begóniák

Rex Begónia

Begónia, pettyezett levelü

Colla

Citromfa

Drocena

Asparagus

Fukszia

Gummifa

Kaktusz ojtott

Lantana

Oleander

Pálma

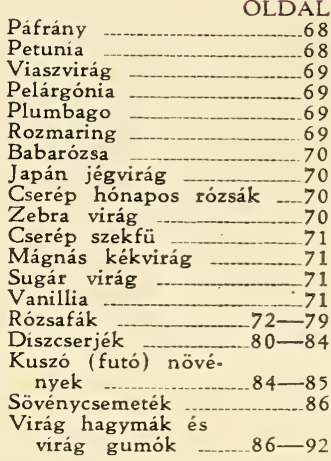

\section{GYÜMóLCSFÁK.}

Almafajok

Körtefajok 96-97

Cseresznyefajok _..._...98

Meggyfajok _... 98-99

Szilvafajok

Barackfajok $100-101$

Birsfajok 101

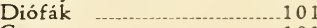

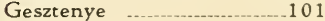

\section{BOGYÓS GYÜMÖLCS} CSEMETÉK.

Köszméte …_- 102

Ribiszke 102-103

Málna (Himpér) -103-104

Szamóca (Eper) 104-105

Szöllök 105-107

Disz-és Árnyékfák 108-110

Fenyőfák … 111

Rovarölö porok 112 
